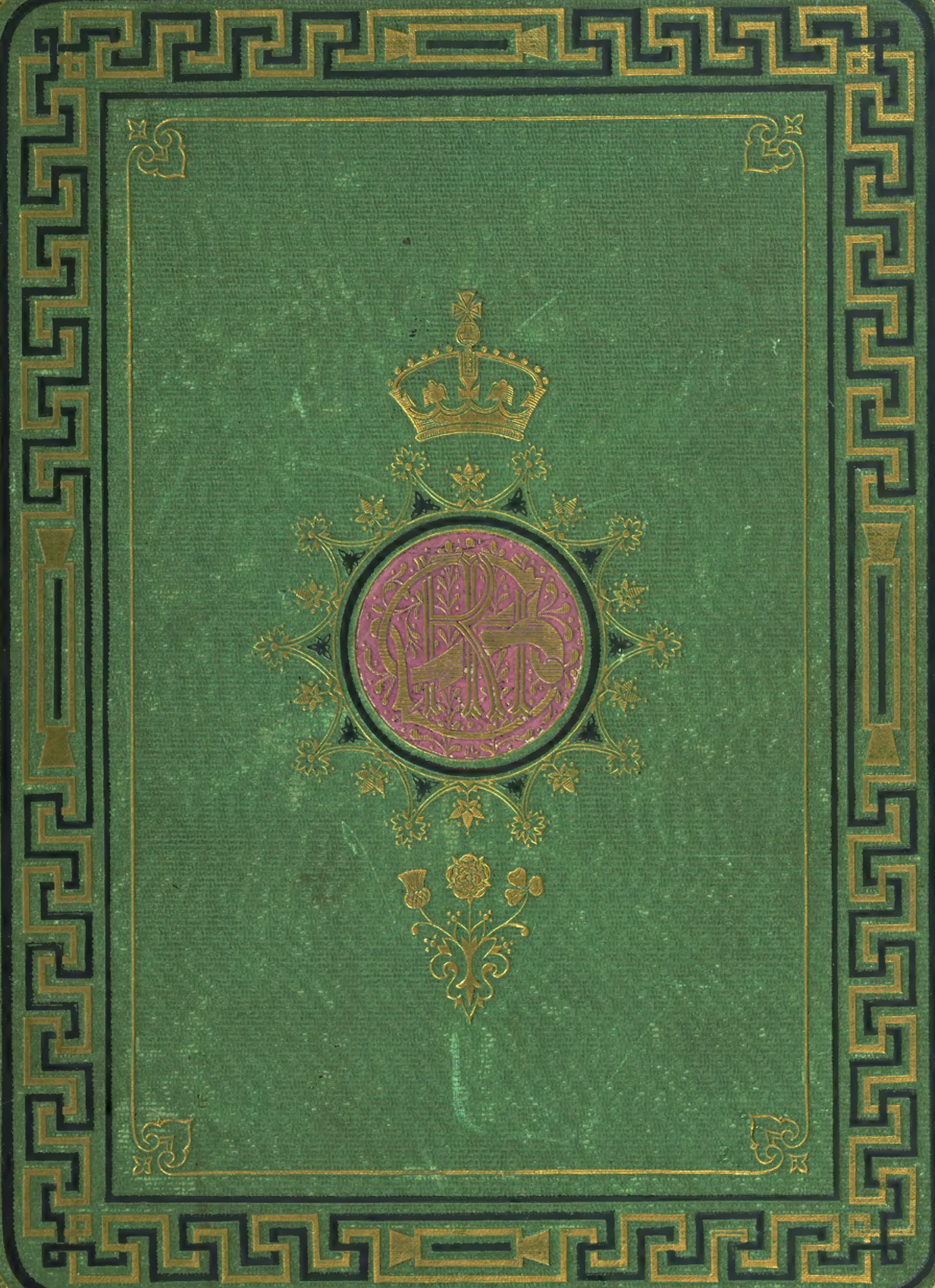




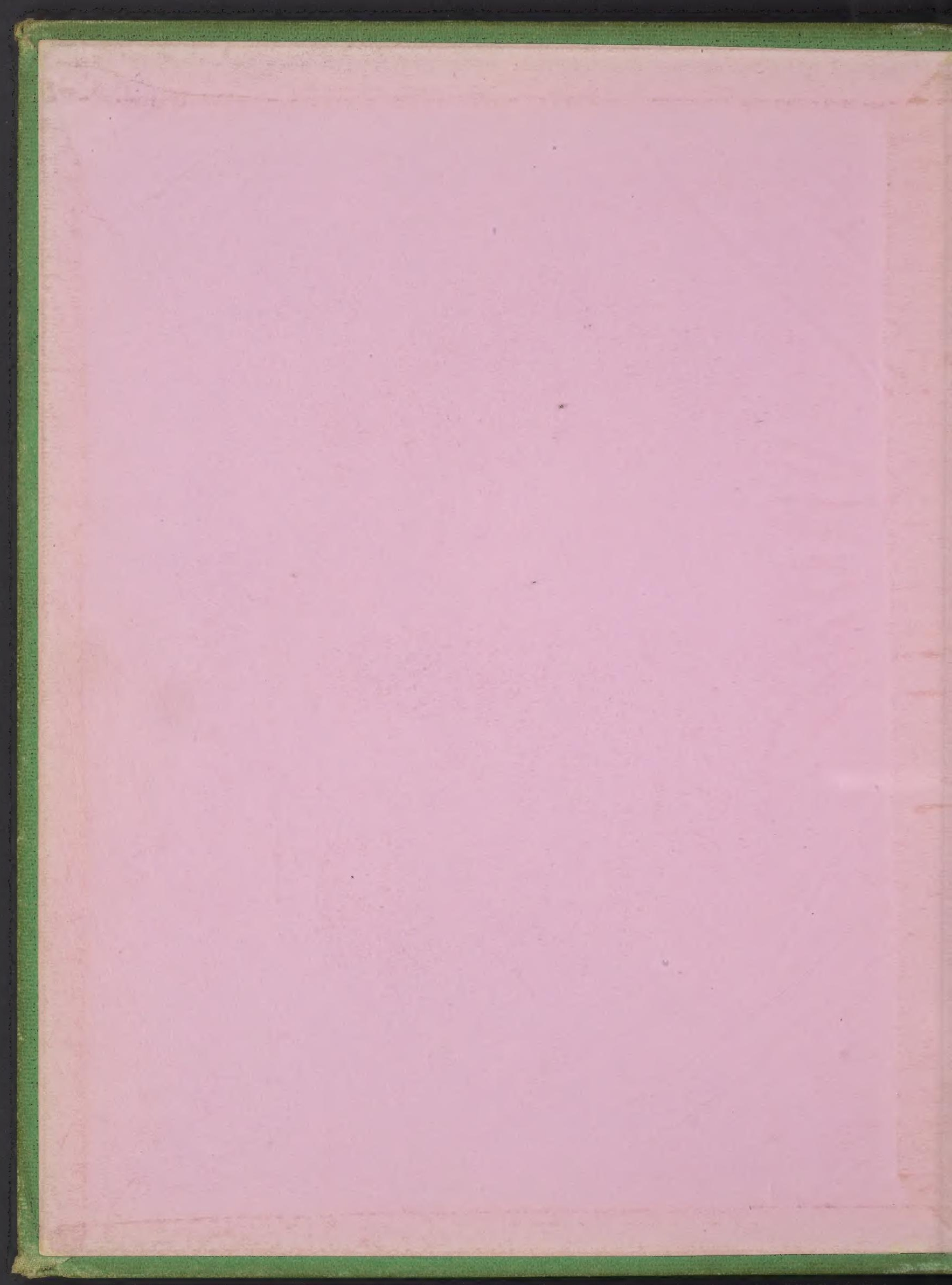





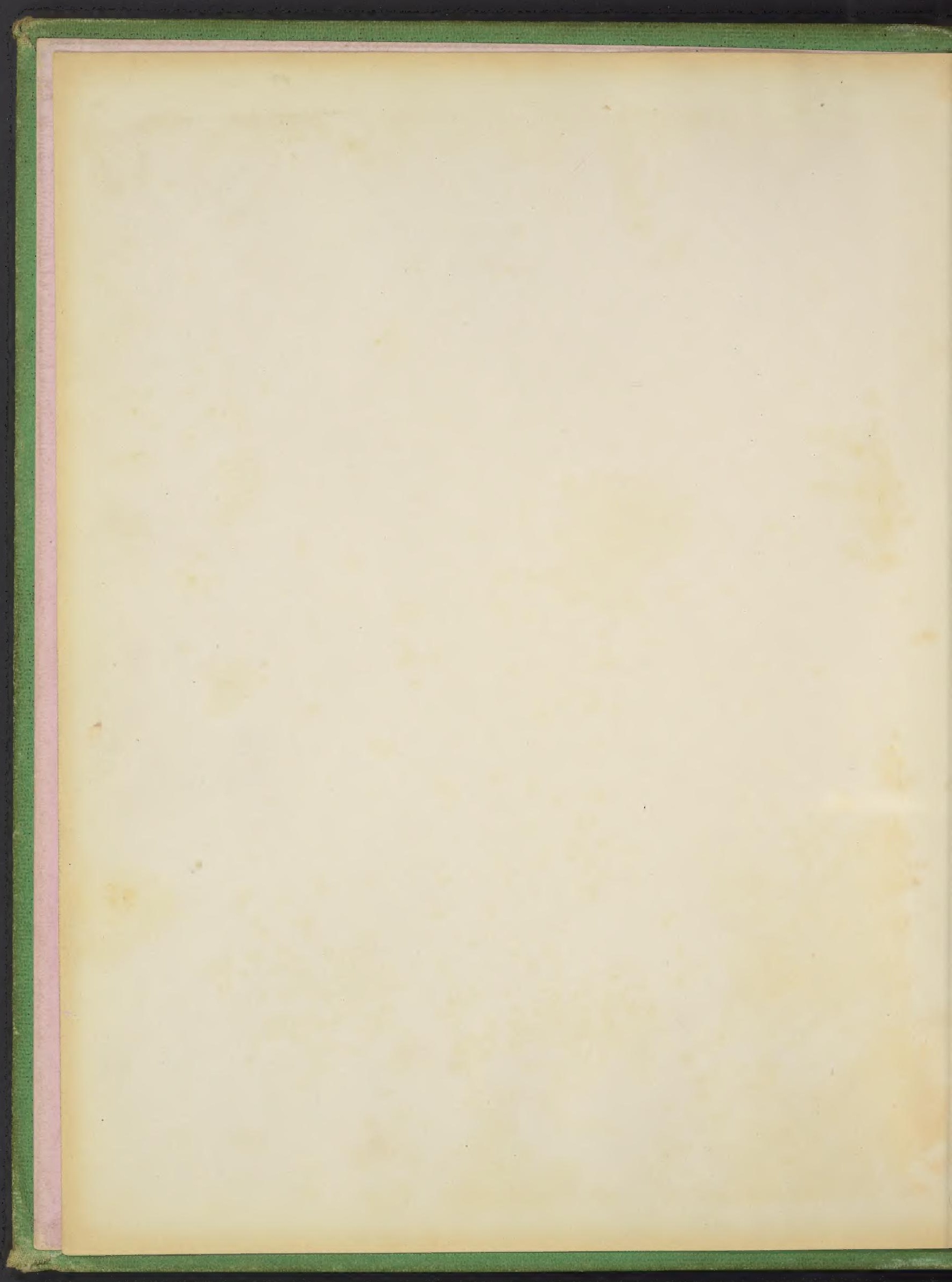




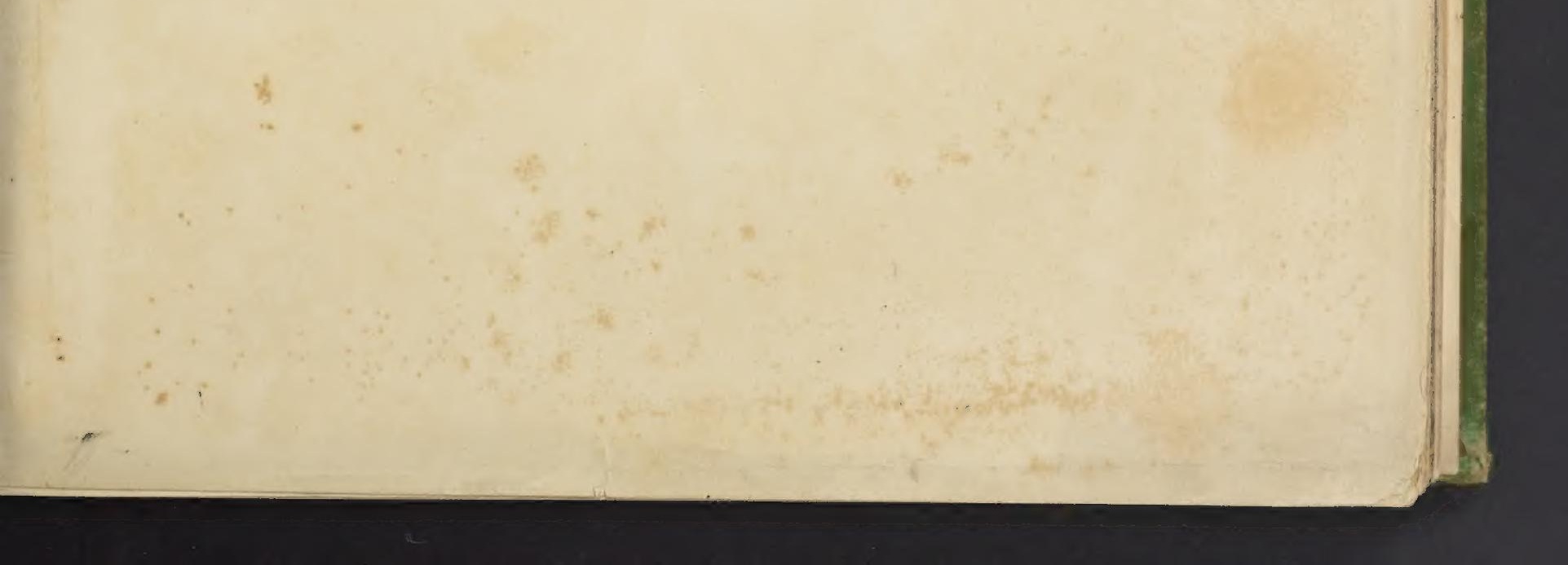



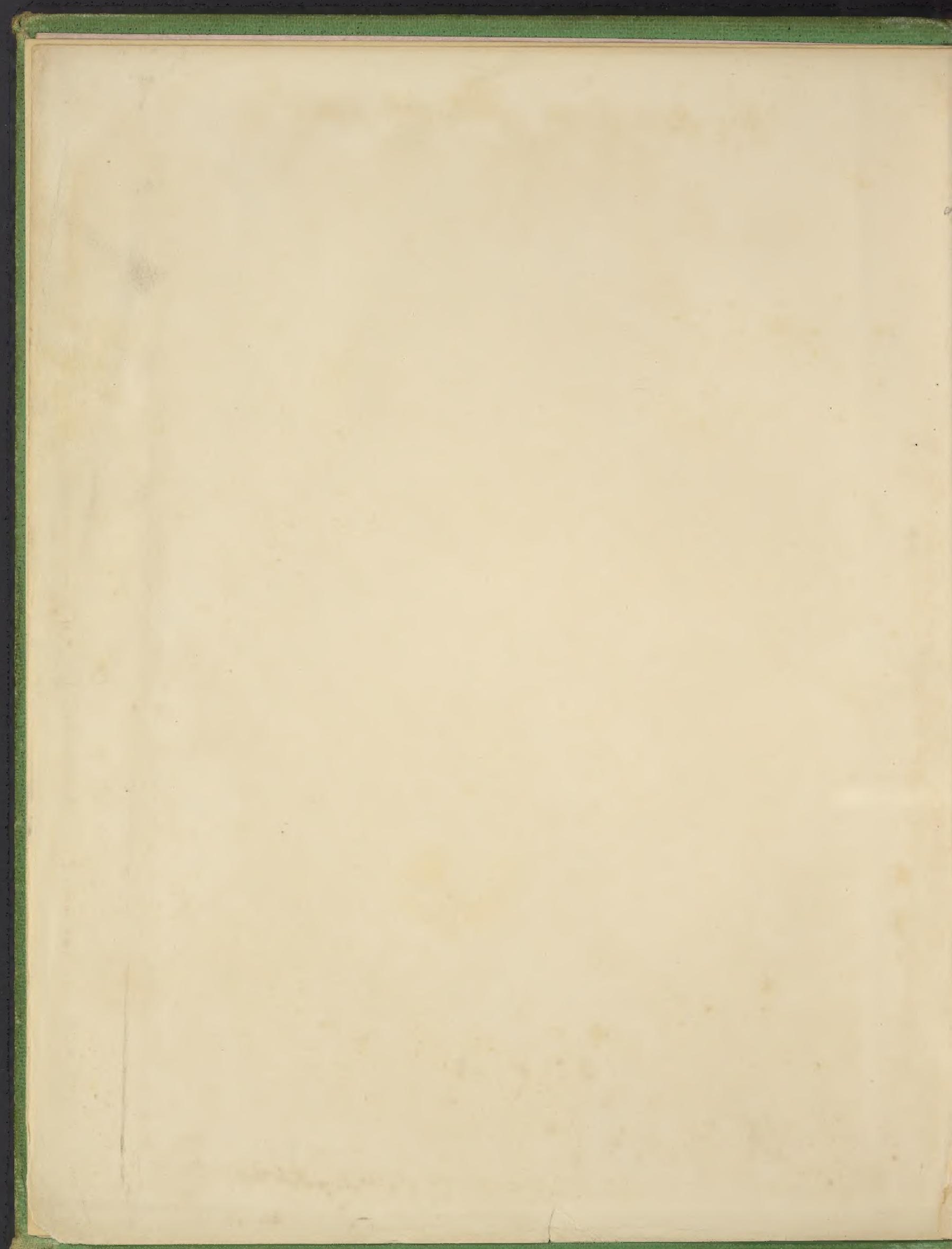


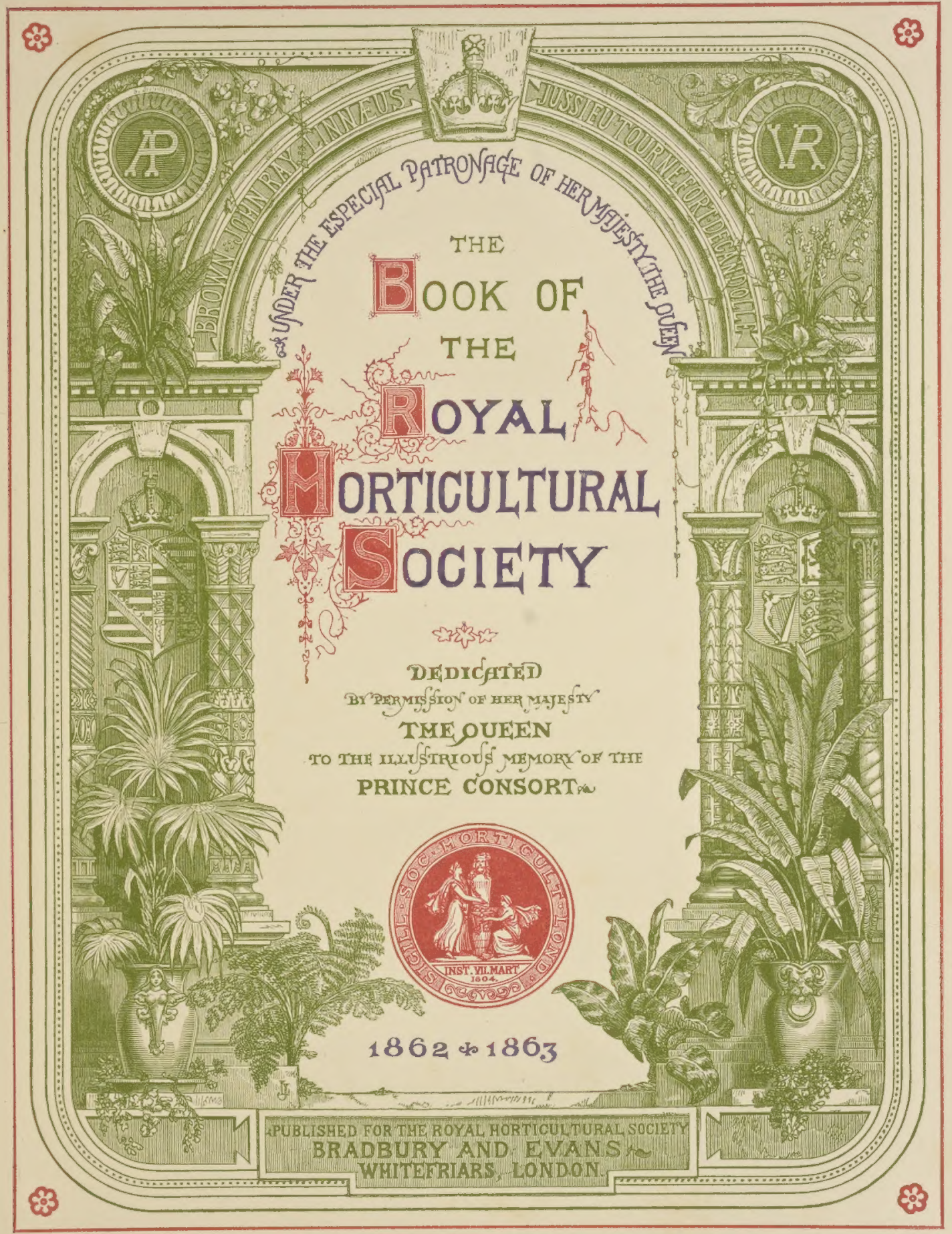




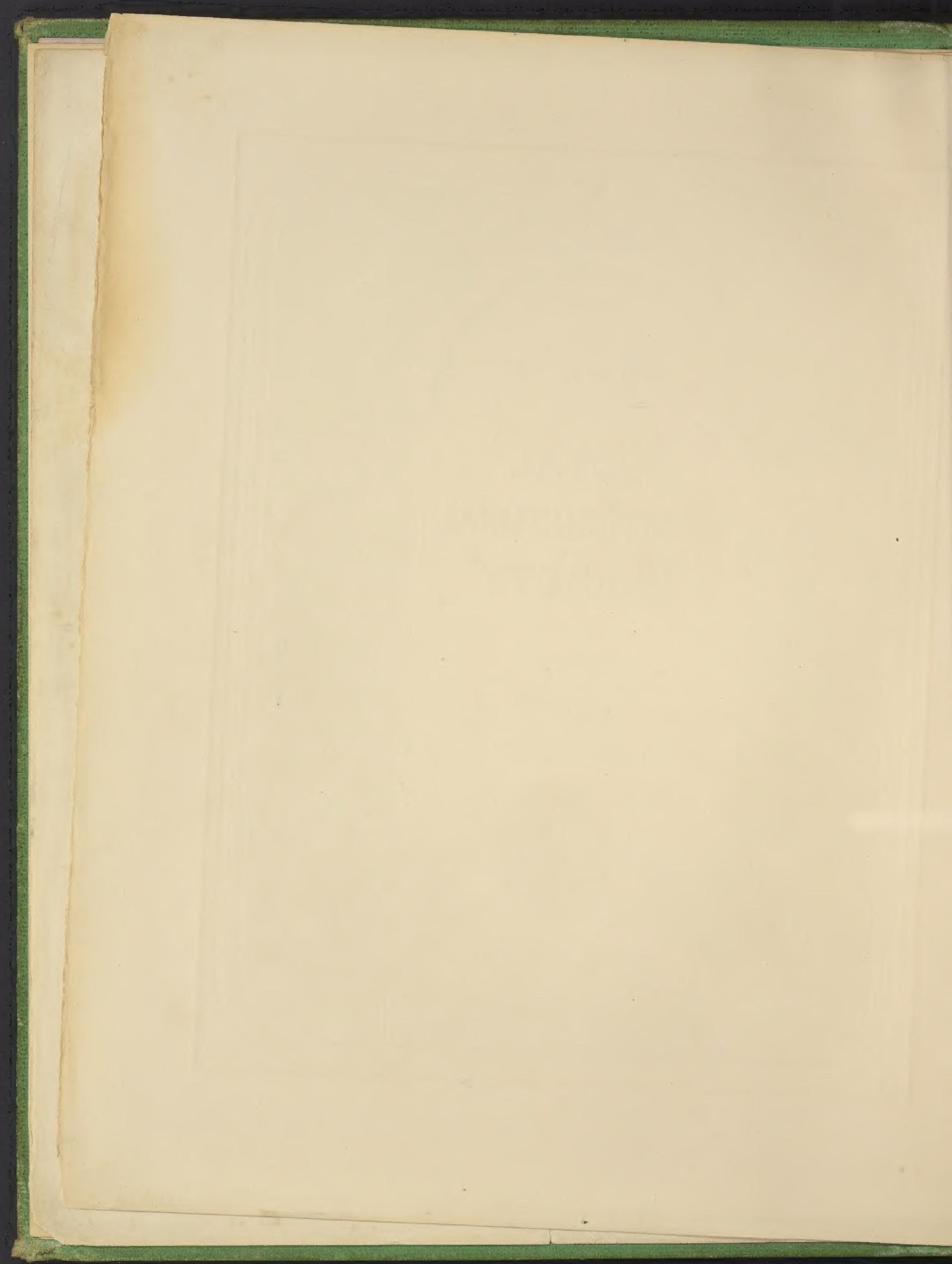




\section{THE BOOK OF THE ROYAL}

\section{HORTICULTURAL SOCIETY.}

$1862-1863$.

By ANDREW MURRAY, EsQ., F.L.S. \&e.

(ABSTSTANT SECRETARY TO THE ROYAL, HORTIOULTURAL BOCIETY,)

\section{đllustrations and alfotographs}

BY JOHN LEIGHTON, F.S.A., THOMAS SCOTT, AND C. THURSTON THOMPSON.

LONDON :

BRADBURY AND EVANS, 11, BOUVERIE STREET.

MDCCCLXIII. 
BRADEURY AND EVANS

PRINTERS EXTRAORDINABY TO THE QUEEN,

WHITEFRIARS. 


$$
\text { To the }
$$

过llustrions a

\section{of

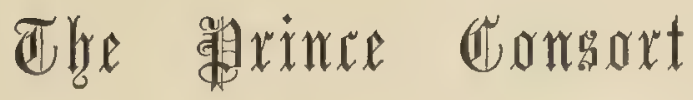

THIS VOLUME IS INSCRIBED

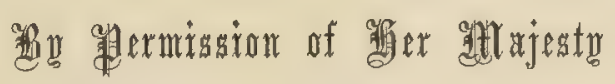

The (ienent 


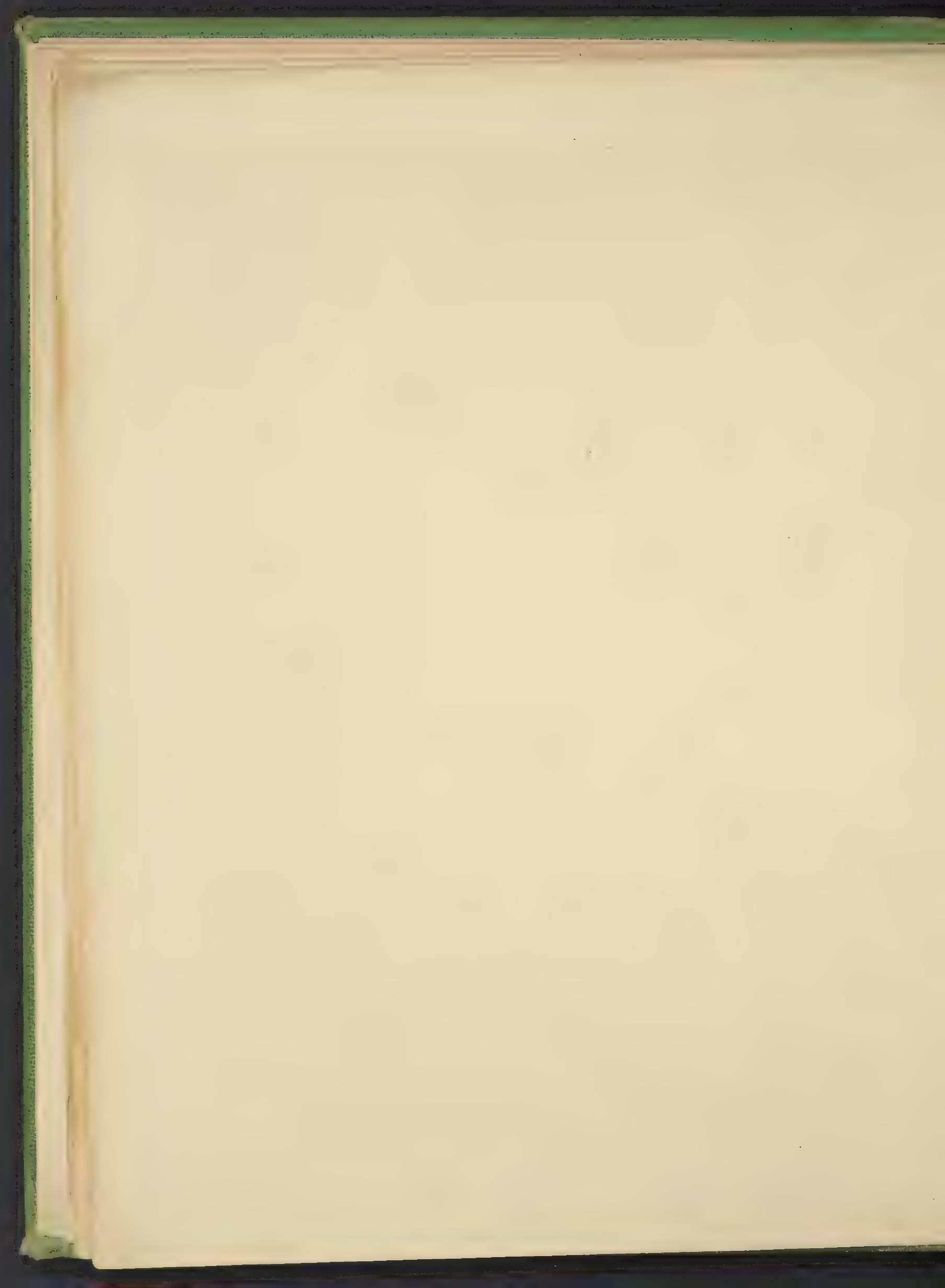


斯 1 , moumed, and yet not lost, but gome before,

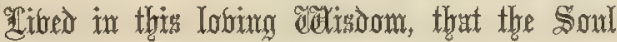

Should be a Garden, by the getretous dole

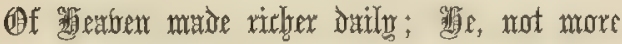

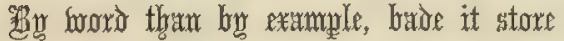

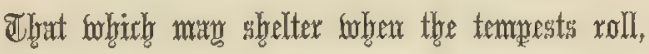

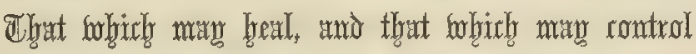

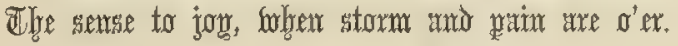

So, to the ettemoxy of the kindo, thre trixe,

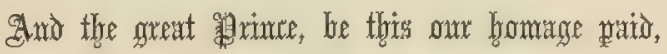

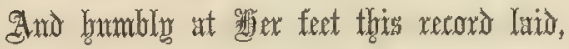

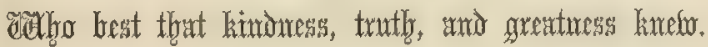

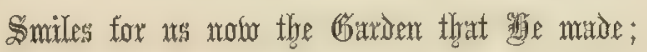

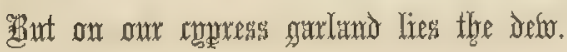




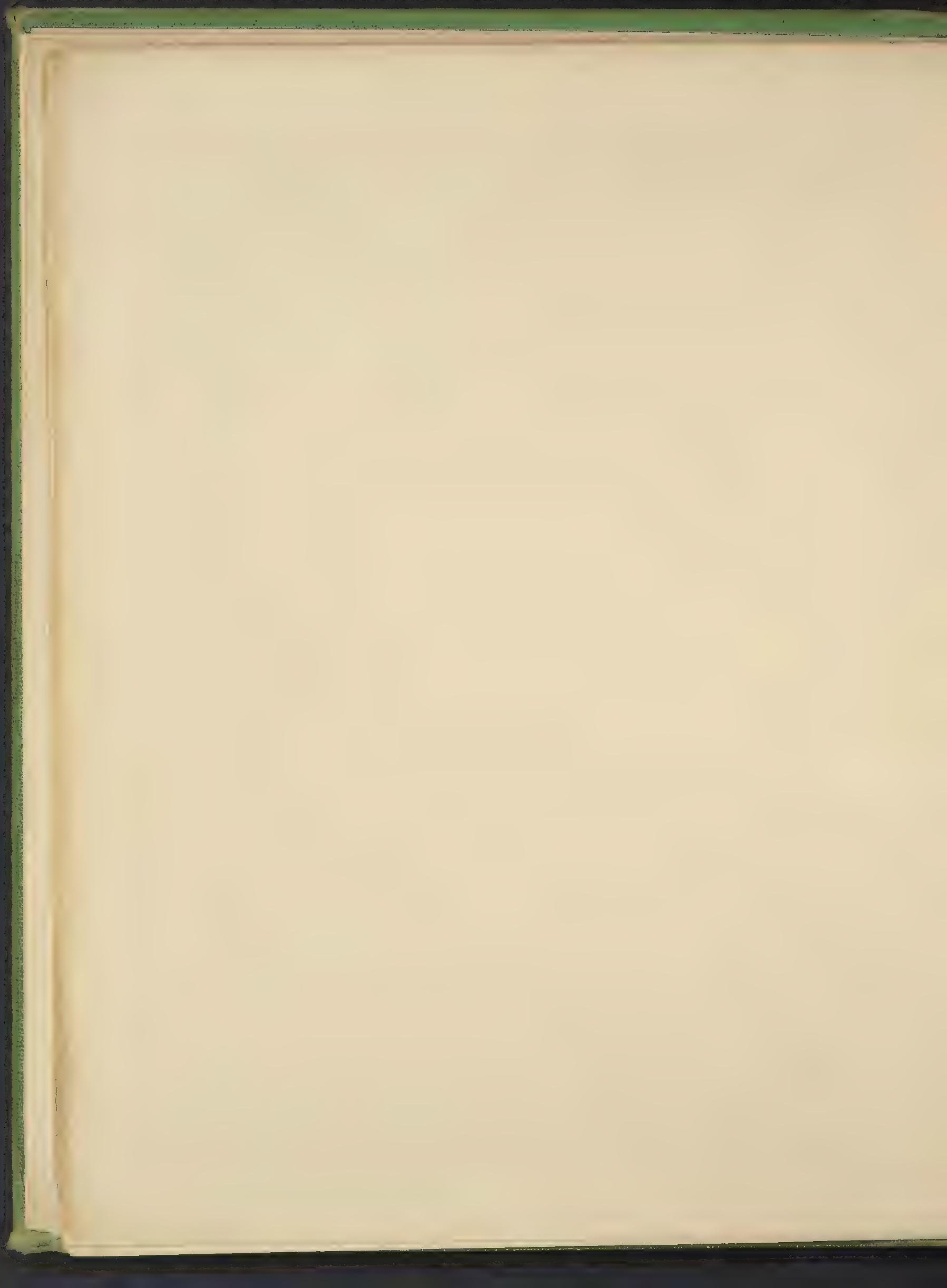




\section{PREFACE.}

THE important results which have attended the labours of the Royal Horticultural Society, the character and position of its Fellows, and the Royal patronage it has received, have invested it with the dignity almost of a National Institution. A work devoted to its past History and present state cannot therefore be regarded by the public as trivial or unnecessary, and must possess special interest for the Fellows themselves. The present seems to be the time, too, for the appearance of such a work; for as in the poet's drama event is crowded upon event as the scene advances, until, when our interest has reached its climax, the curtain falls upon the sacrifice of the hero, so the History of this Society has gone on increasing in interest and importance, reaching its climax in the Presidency of the Prince Consort, and completing the parallel by the abrupt termination of his brief but brilliant career. The curtain of Fate has fallen on the bero of our drama, and a broad and well-defined chasm, marked by his loss, separates the past History of the Society from the future.

To this stage I have brought down the History which is offered to the Fellows and the public in the following pages. Starting with the 
PREFACE.

establishment of the Society some sixty years ago, by a few gentlemen who desired to raise the practice of gardening from its then state of apathetic routine to the dignity of a science, I have traced it from its cradle in a garden not far from that now occupied by the Society at South Kensington, to the world-renowned establishment at Chiswick, and thence back to its present home. I have shown its first slow but steady progress; the gradual extension of its aims; the meteor-like brilliancy of its first rise. I have had to record its difficulties and decline, its recovery, and still more triumphant success under the management of Dr. Lindley; its national usefulness; its expeditions, explorations, and discoveries; the more important of the new plants that have been introduced by its collectors; its scientific publications, experiments, exhibitions, and a multitude of other labours. Again it languished, and was sick nigh unto death. I have followed it through its financial difficulties; shown the desperate efforts made, not only by the Council, but by the Fellows, to save it, and their failure one after another: until, at its utmost hour of need, when nought but speedy extinction looked it in the face, the Prince Consort took it by the hand, and, as it were with a word, raised it to its feet and restored it to vigour, giving it strength and resources beyond any it had previously possessed; raised, as if by enchantment, the Arcadian Garden at South Kensington; organised the International Exhibition of 1862, and pointed the way for the Society participating in its advantages. Of all these proceedings I have given the details. I have also had to tell of the unspeakable loss sustained by 
the Society, in common with the Nation, and to record the sustaining encouragement which the Queen and the Prince of Wales have condescended to give to the Society.

Here, perhaps, it might be thought that my subject should end; but practically it cannot be said to be complete without a record of the proceedings during the year of the International Exhibition, which must be reckoned part of the Prince's work, as being the mere natural and necessary sequence of his plans and arrangements. So also an account of the completion of the Memorial of 1851 was essential to wind up the history of that important Monument to our Great and Good Prince. This History, therefore, may be said to be brought down to the 10th of June, 1863.

After completing the record of the History of the Society, I have devoted the rest of the work to a description of the Garden at South Kensington, with full details and illustrations of its decorations; not only speaking of those which have been permanently placed in it, but of the more important of those which found a temporary home there during the period of the International Exhibition.

The materials from which this work has been drawn are chiefly the authentic records preserved in the archives of the Society. I have thankfully to acknowledge much valuable information received from Dr. Lindley and Sir Wentworth Dilke, regarding the past history of the Society; 


\section{PREFACE.}

from Mr. Cole and Captain Fowke, as to the architectural statisties of the Garden; and from Mr. Durham and Mr. Godwin, relating to the Memorial of the Exhibition of 1851.

To artist, printer, and publisher, thanks alike are due. Every one has lent himself to the production of this work-a modest attempt to add a stone to the cairn raised to the memory of the GrEAT CHIEF who is gone-as to a labour of love.

ANDREW MURRAY.

Kansington,

June 9, 1863. 
CONTENTS.

SONNET, BY SHIRley Brooks. (Dedication).

PACE The Establishment, Early History, ard Progress of the Society * . . 1 The President of the Prince Consort, ANd the Memorial of 1851 . . . 45 The SOCIETy IN CONNECTION WITH THE INTERNATIONAT ExHIBITION, 1862 • • 89 The Description of the Garden, Conservatory, Statues, \&c. . . . . . . 109 APPENDIX

ILLUSTRATIONS ON WOOD.

TITLE.

ERONTISPIECE. AUTOGRAPH OF THE QUEEN (facsimile).

"Mr. Rose Presenting the first English-grown Pine-Apple to Charles the SECOND"

VIEW OW CHISWICK HOUSE AND LAWN

AUtograpH OF the PrINce CONSORT (facsimile)

Original Design for the Memorial of 1851, by Durham THE MEMORIAL OF 1851

Entrance to the Garden from the Counchl-Room Group in Bronze-Mastift and Whelps The Entrance in Exhibition Road PoRtion of IATterax ARCADE The Amalthea of JULIEN Cloister of San Pablo (from the Lateran) Portion of ColonNades surrounding THE AnTe-Garden MaRochetTI's MoNUMENT OF CharLes ALBERT Steps LeadiNg to LOWER TERRACE VIEW UNDER ARCH OF EAST BRIDGE

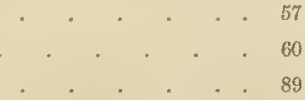
33 The Large French Fountain, designed by Flagman "Smaller " $\quad$ " designed by Moreat .
$. \quad . \quad 108$
$. \quad . \quad 109$
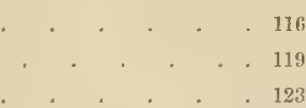

$$
123
$$$$
\text { - } 125
$$
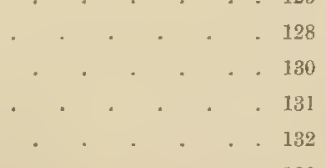
ii 


\section{CONTENTS.}

THE GARDFN A RCADT OF THE ALBAYT VILTHA, ROME THE CONSERVATORY . . . . 140

Marble Statue of "Spring," by Francavilla . . . . . . . . 142

" "SUMMER," " . . . . . . . . 142

Westmacote's Statue of "The Peri" . . . . . . . . . 143

Yontr's "LTGHT OF "THE HaRem"

VIEW OF ONE OF THE BAND-HOUSES . . . . . . . . . . . .

Statuette Figure of Girl Drinktifg From Shell, by Moreau . . . . . 167

STATUETTE OF BOY AND DUOK . . . . . . . . . 167

Statum of Juno, by Morttz Gerss, (presented by the Prince Consort) . . . 168

" CERES, " ". . . . 168

SHEPHERD ATTACKED BY A LION . . . . . . . 169

StATUE OF VICTORY, by RAUCH . . . . . . . . . . . . . 170

STATUE OF HUSBANDEY - . . . . . . . . 173

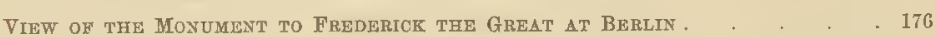

STATUES OF "TEMPERANCE" AND "Stringth," (copied from the Monument to

Frederick the Great) . . . . . . . . . . . 17t

Cakal and Small CAscade . . . . . . . . . . . 179

\section{PHOTOGRAPHS}

Portico of Cotroil-Room, with Entrance into the Garden . . . . to face 1

SCUlptoke IN The CONSERvatory . . . . . . . . . . . " " 72

The Garden and THE ExHibition Butldina, looking South-East . . , 89

General Vraw of the Garden, From the Exhibition Butldixg . . " " 109

VIEW OF THE GARDEN, LOOKING NORTH-WEST . . . . . . . " 117

ThE COUNCIL-ROOM (from a Drawing) . . . . . . . . . " 121

Albani ArCades, South-East Corner . . . . . . . . . " 136

THE Alcove IN THE CONSERVATORT . . . . . . . . . " 147

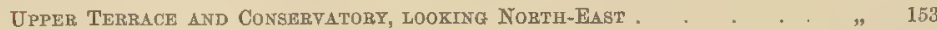

The Great Cascade . . . . . . . . . . . 156

The Canal and Small Cascade . . . . . . . . . 166

View of UPper Arcades, SHOWING RibBON BEDS, \&cc. . . . . . . . " 172

A Bird'S-gYe VIEW OR PLAN OF THE GARDEN , . . . . . . , " 180 

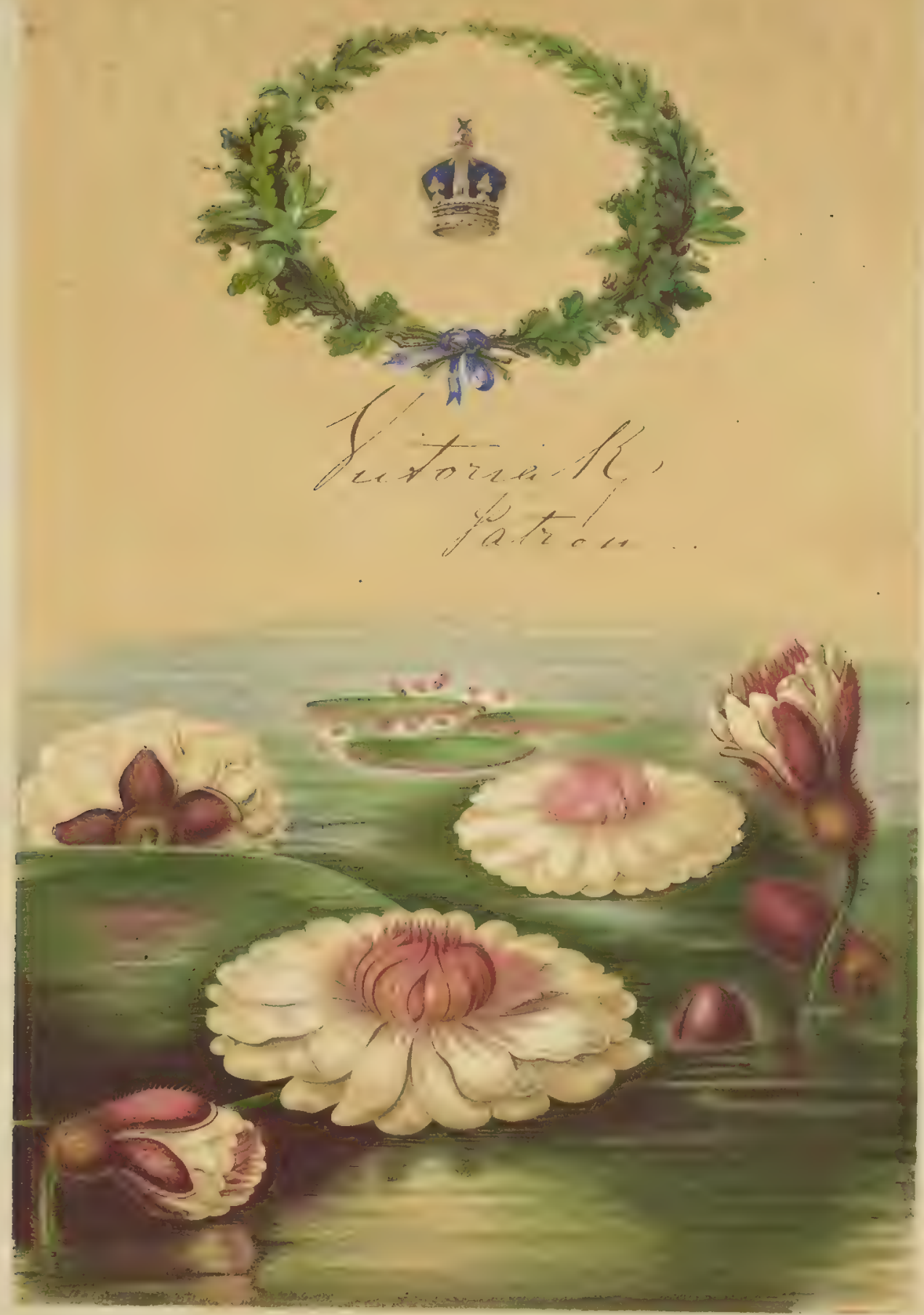

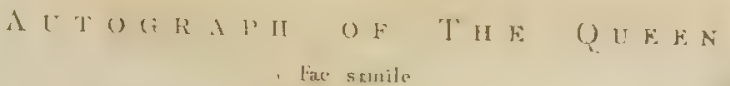




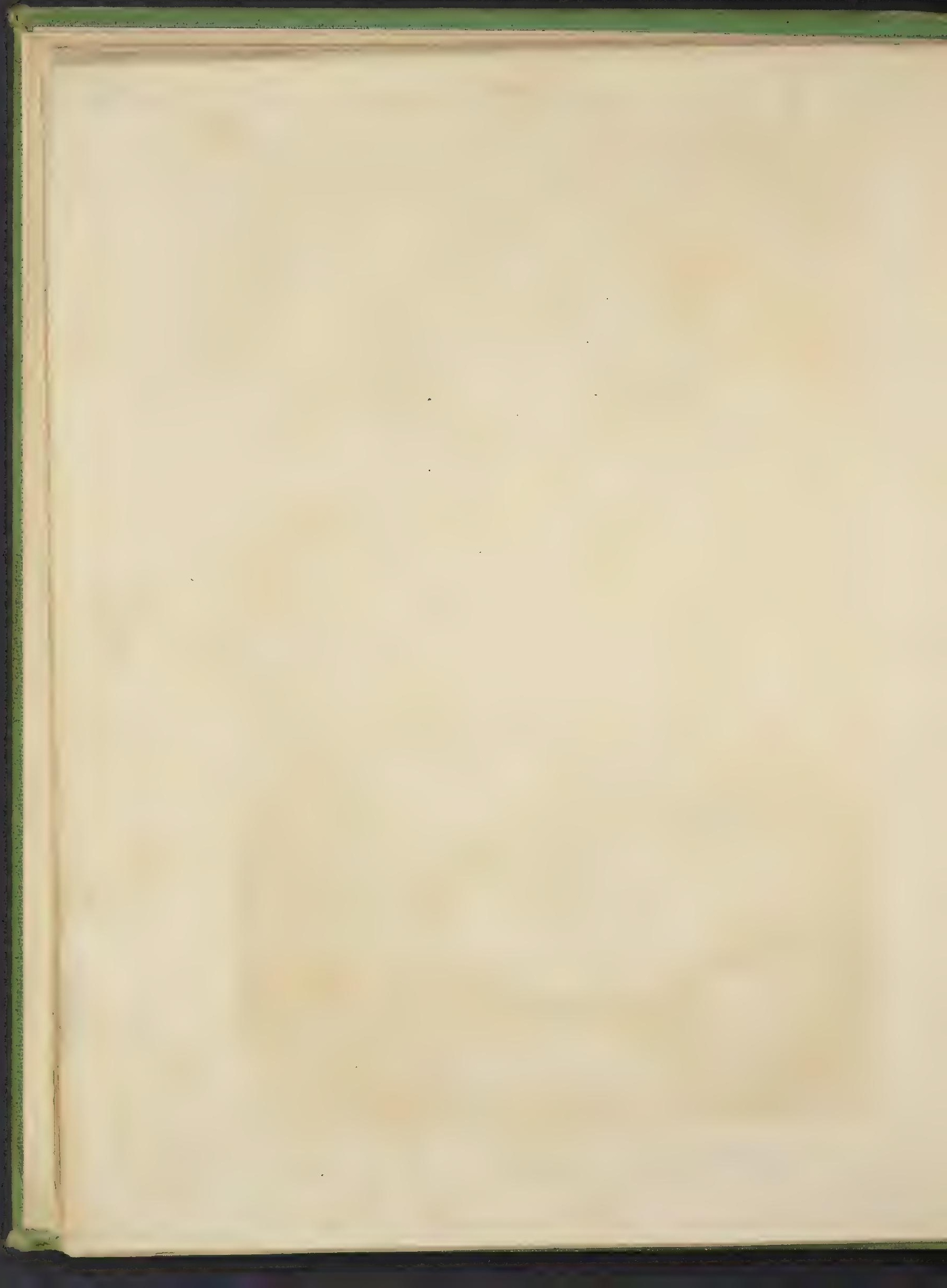


THE ESTABLISHMENT, EARLY HISTORY, AND PROGRESS OF THE SOCIETY. 


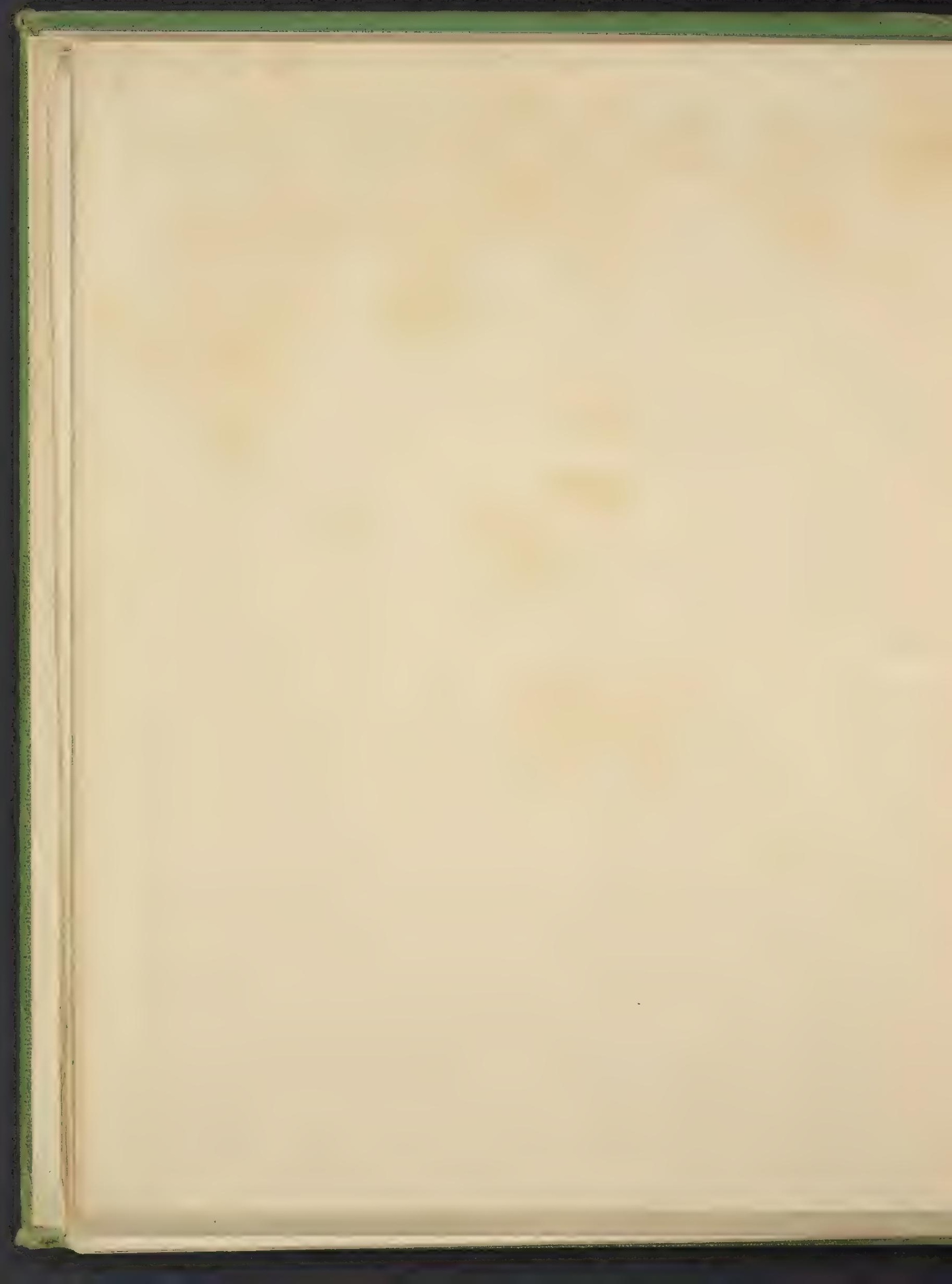




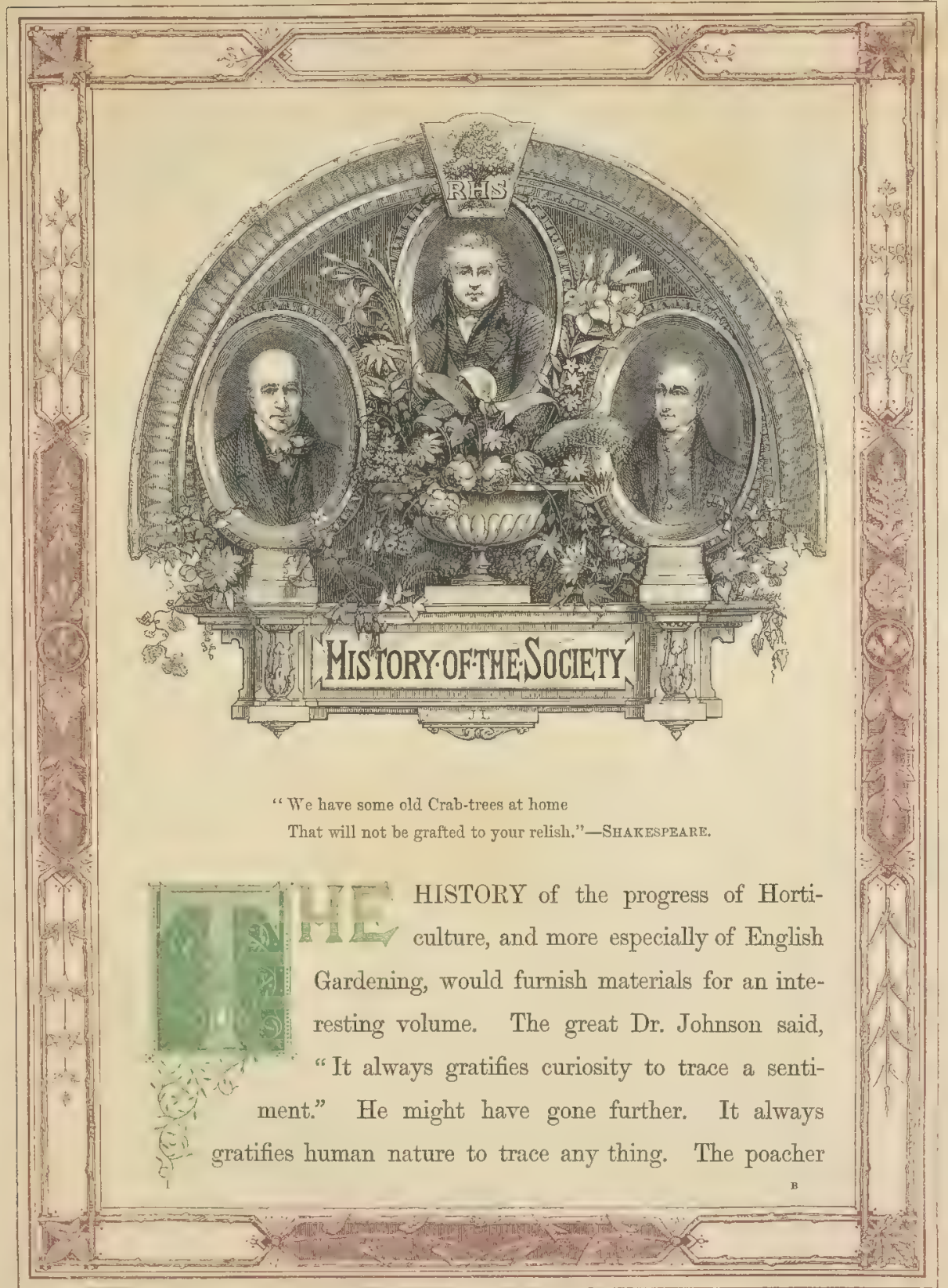




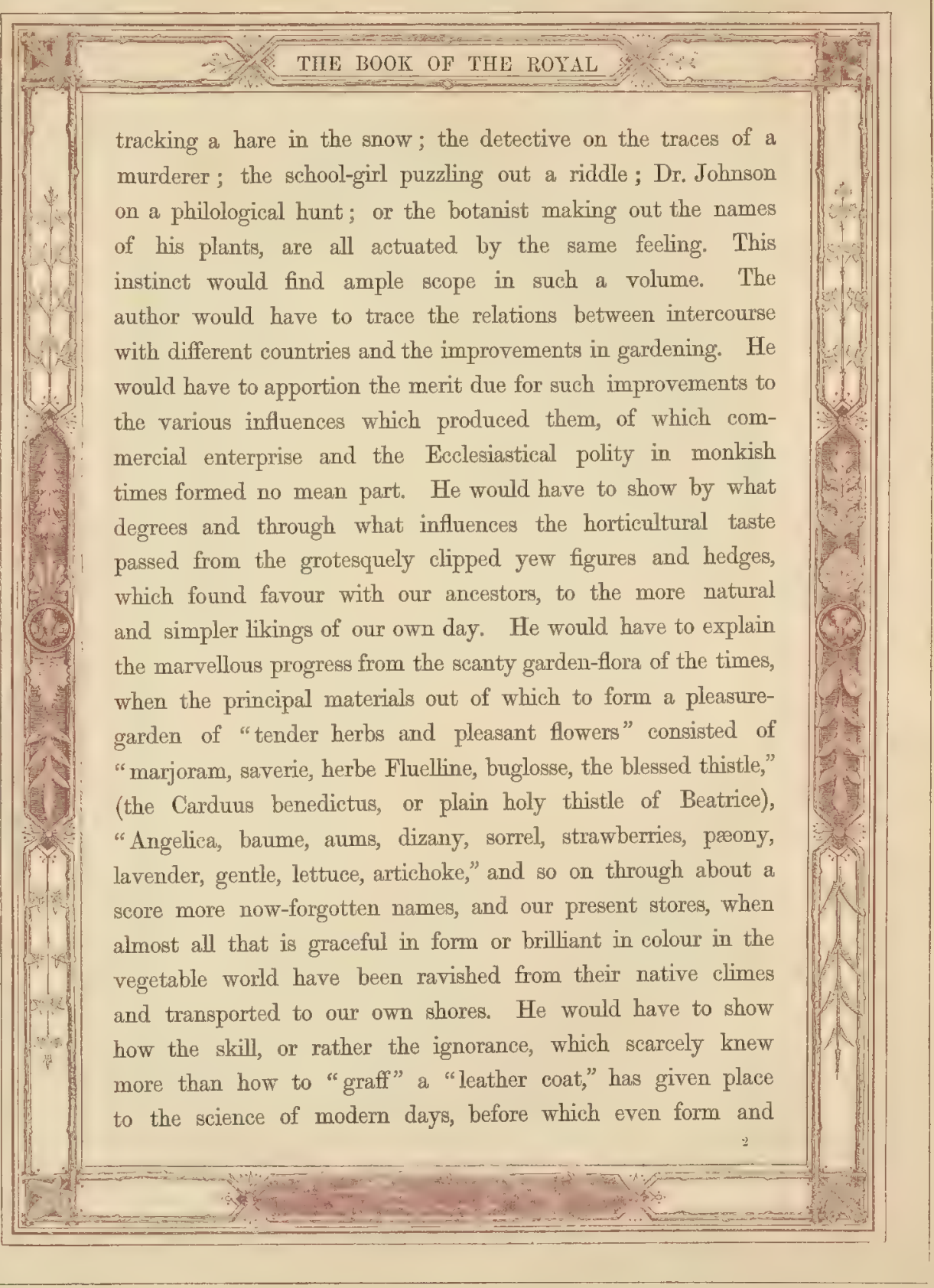




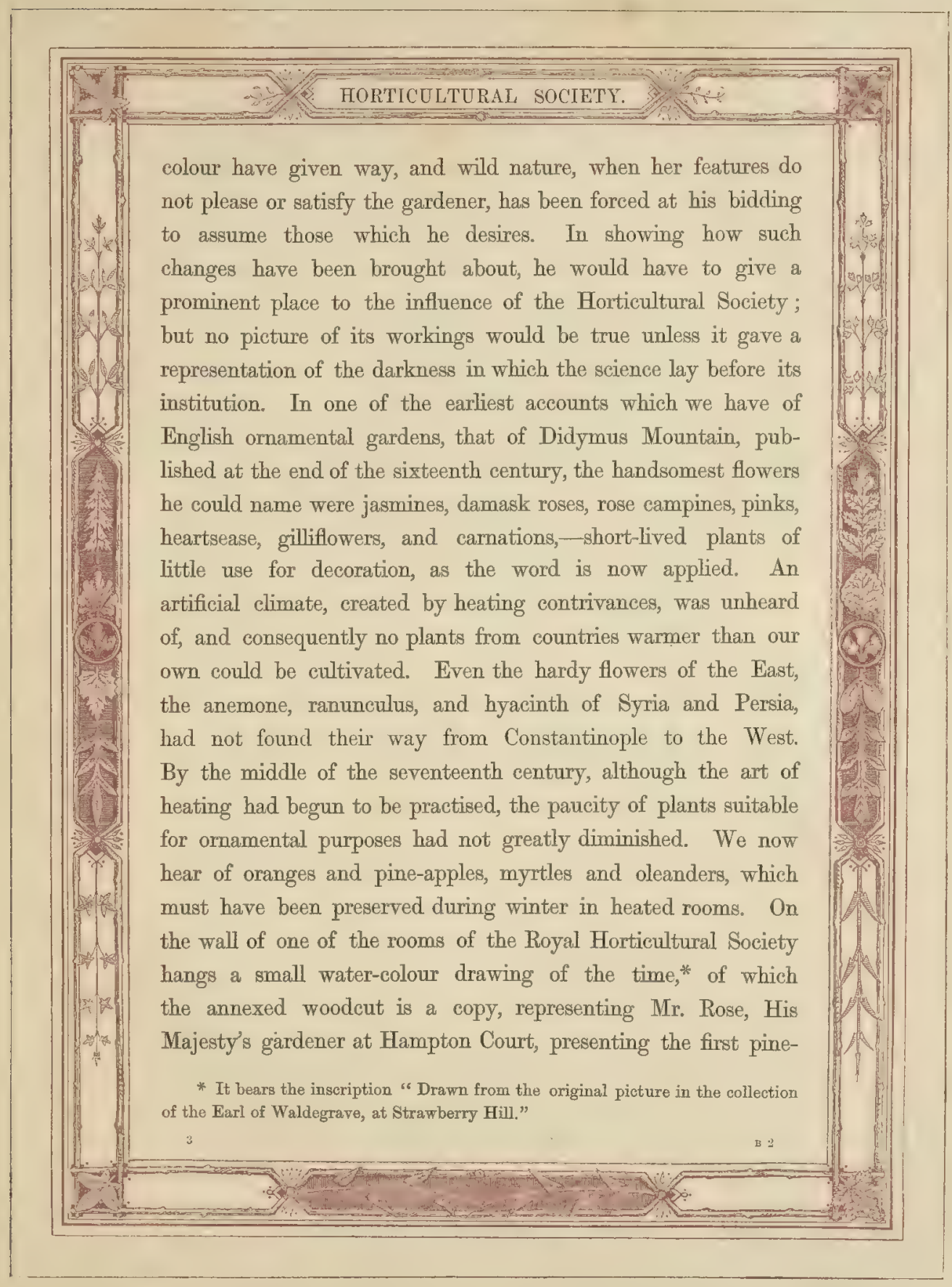




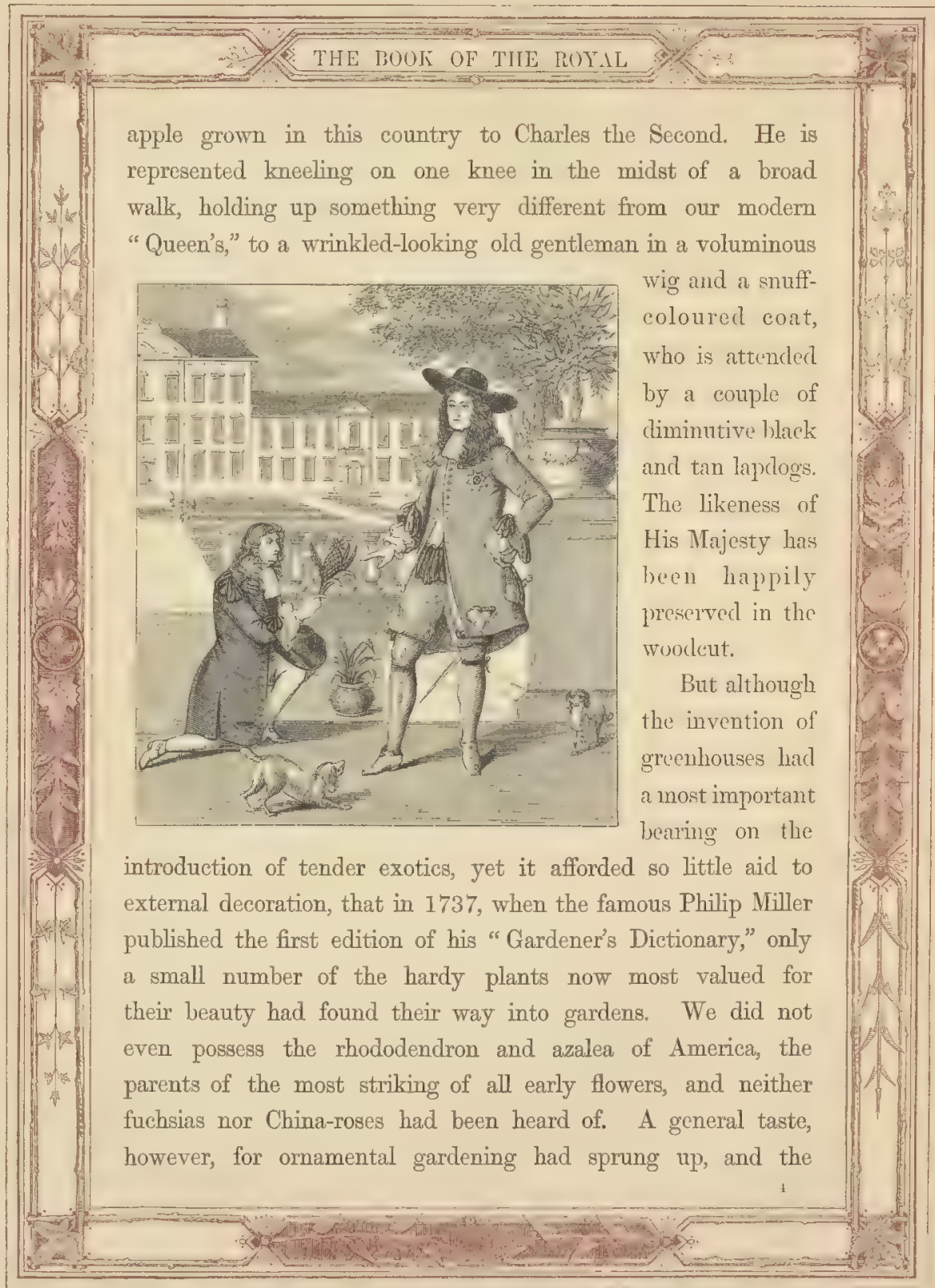




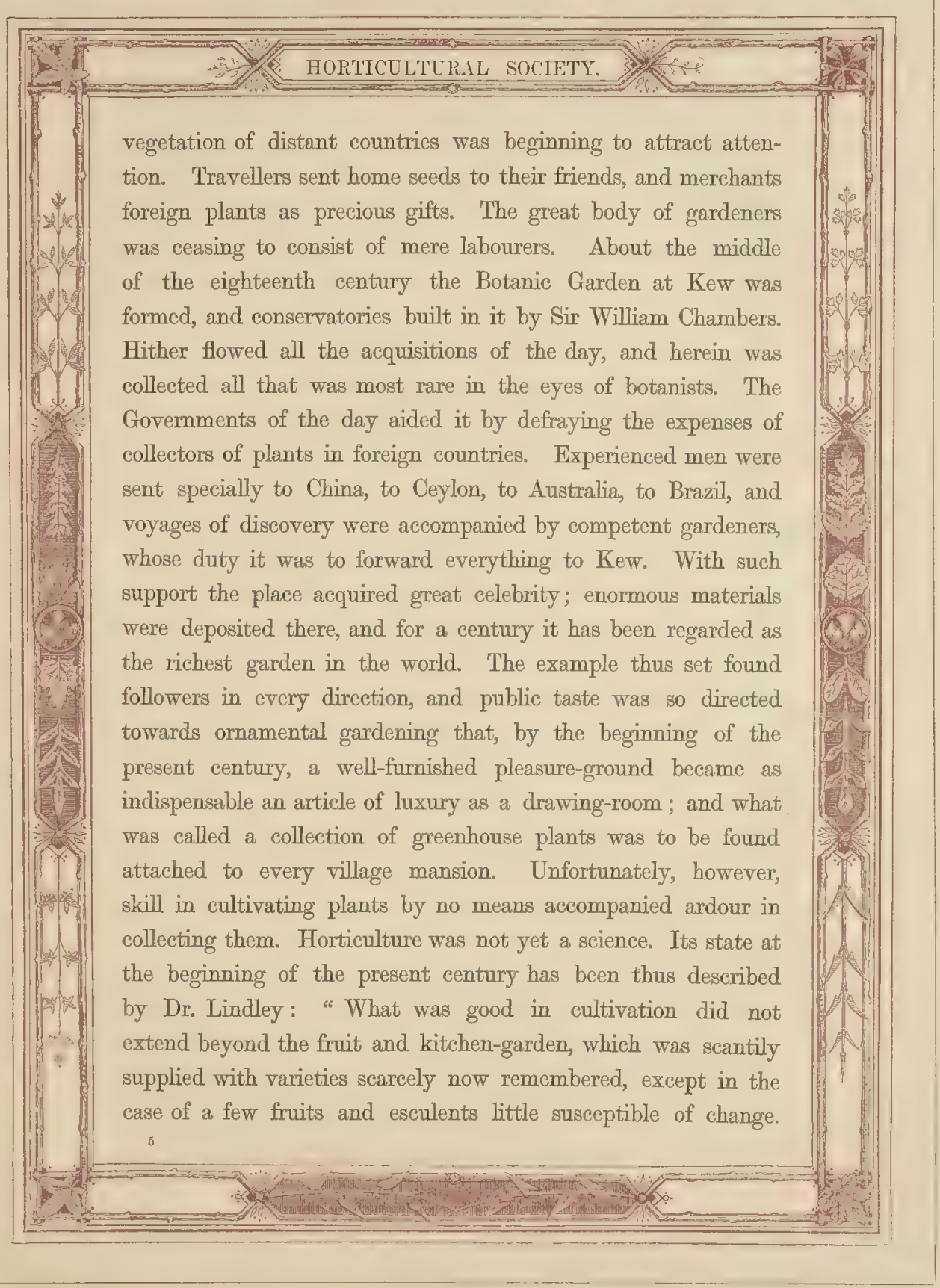




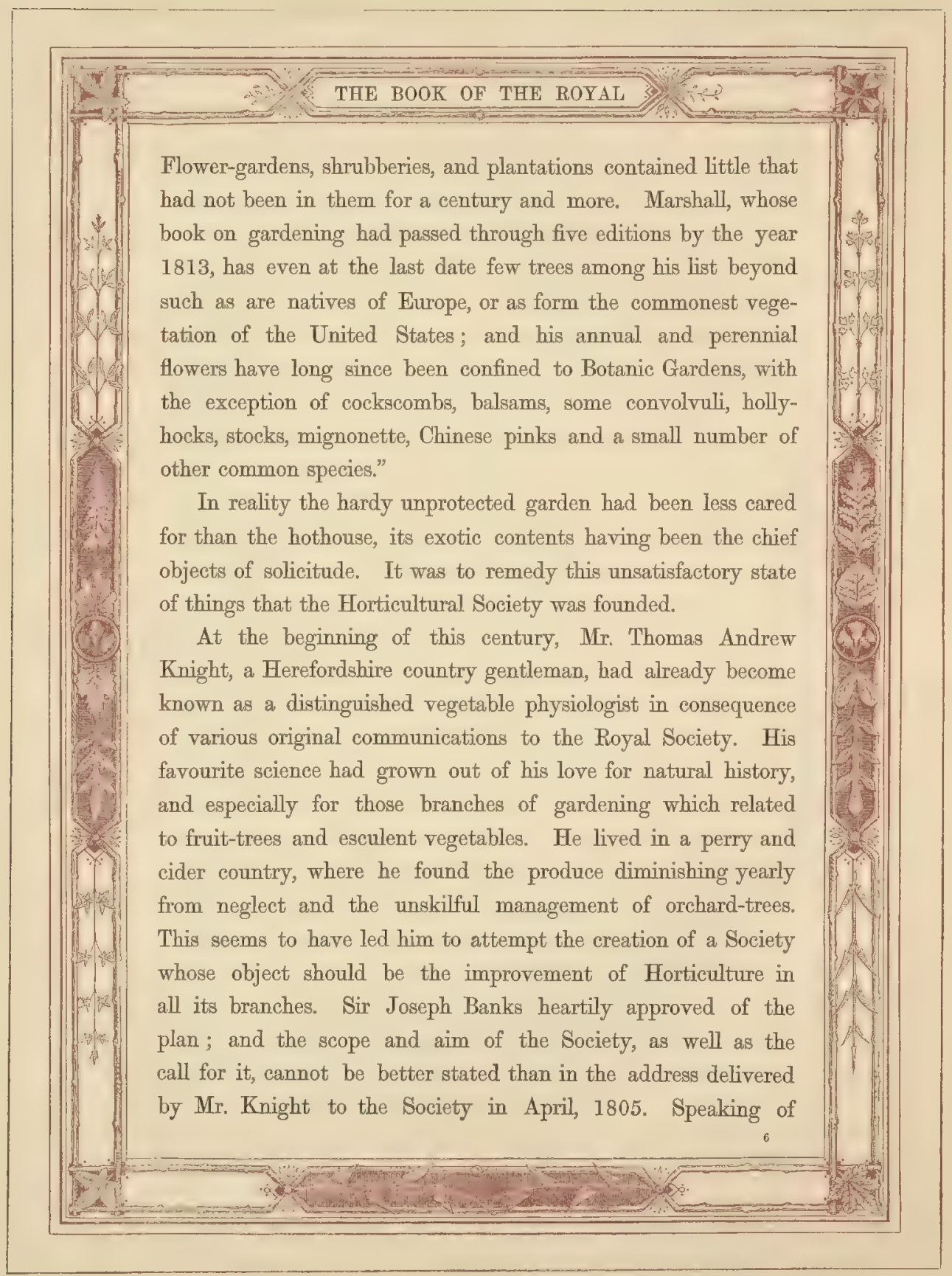




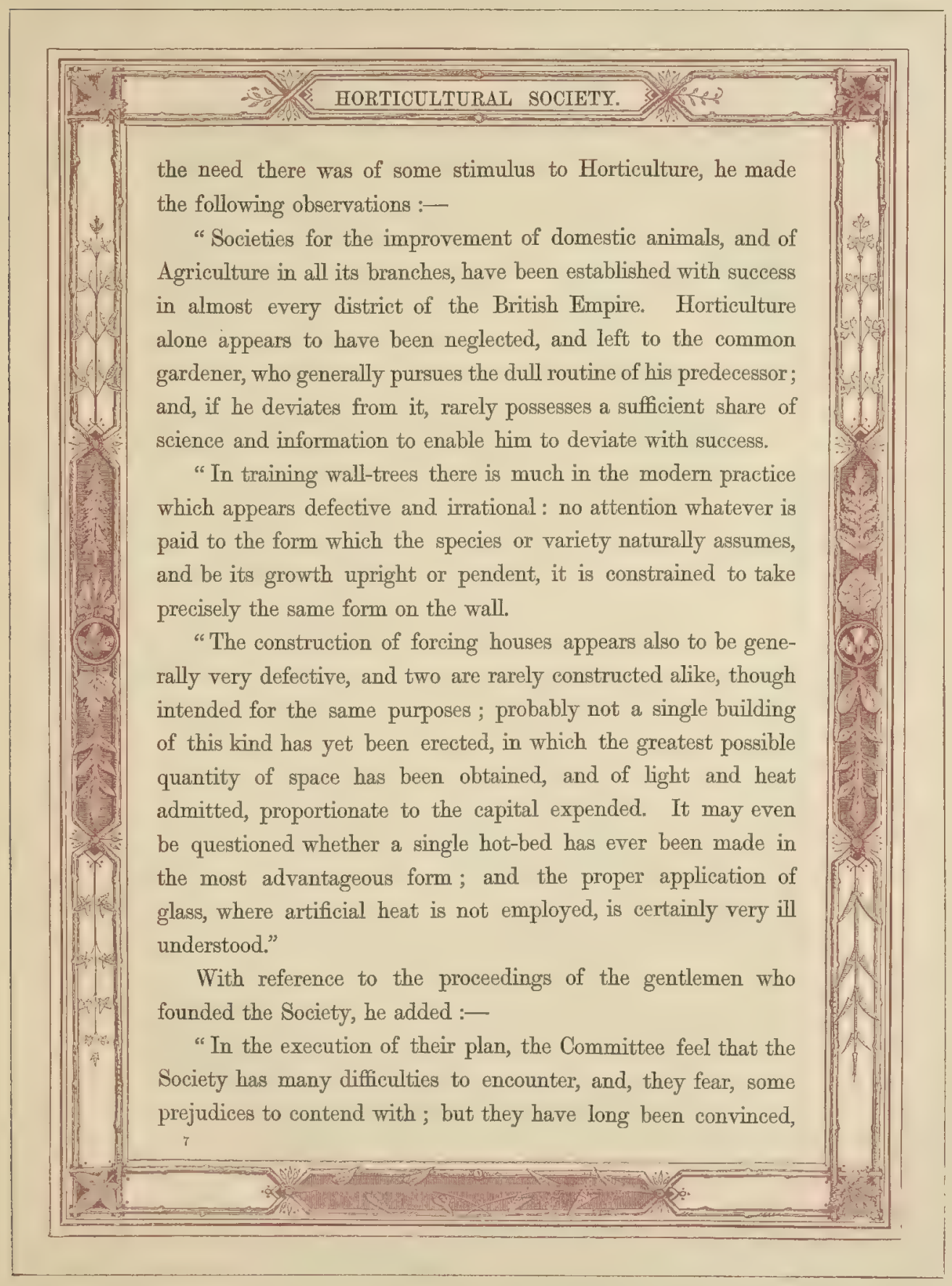




as individuals, and their aggregate observations have tended
only to increase their conviction, that there scarce exists a single
species of esculent plant or fruit, which (relative to the use of
man) has yet attained its utmost state of perfection ; nor any
branch of practical Horticulture which is not still susceptible of
essential improvement.
"The establishment of a National Society for the improve-
ment of Horticulture has, therefore, long been wanted ; and if
such an institution meet with a degree of support proportionate
to the importance of its object ; if it proceed with cautious
circumspection to publish well ascertained facts only, to detect
the errors of ignorance, and to expose the misrepresentations of
fraud; the advantages which the public may ultimately derive
from the establishment will probably exceed the most sanguine
hopes of its founders."
The result has shown that these words were prophetic.




\section{HORTICULTURAL SOCIETY.}

It was on the 7th of March, 1804, in a room in the house of Mr. Hatchard, the eminent bookseller in Piccadilly, that the Society was first organised. On that occasion there were present, Mr. Charles Greville, Sir Joseph Banks, Mr. Richard Anthony Salisbury a distinguished botanist of the day, Messrs. W. T. Aiton and W. Forsyth two of the then royal gardeners, Mr. James Dickson an experienced practical gardener, and Mr. John Wedgwood at whose suggestion it appears that the meeting was called and who afterwards became the first Treasurer.

It was resolved that the objects of the new Society should be "to collect every information respecting the culture and treatment of all plants and trees, as well culinary as ornamental;" "to foster and encourage every branch of Horticulture, and all the arts connected with it;" and "that it shall be considered within the intention of the Society to give premiums for improvements in Horticulture, wherever it should be judged expedient to do so." Each of the gentlemen present at this first meeting paid one guinea towards defraying preliminary expenses, and were called Founders, to whom was afterwards added Mr. J. Hawkins, who had been accidentally absent. It was further agreed that each founder should name, at the next meeting, three other gentlemen for election as Original Members. A week afterwards this was carried into effect; and thus was founded the Horticultural Society of London, an association destined to accomplish most important improvements in the art, as well as science, of gardening, to embellish the country with a vegetation of exquisite beauty before unheard of, to clothe 
our plantations with trees whose ornamental appearance is only equalled by their sterling value, to create by its encouragement new races of flowers, fruits, and even esculents, and to substitute for the glass houses of that day, in which plants could scarcely maintain a languid existence, structures calculated to ensure a richness of growth, greater even than that of the exuberant vegetation of the tropics.

The list of original members included the names of all who in those days were most distinguished for their knowledge of Horticulture.

Its affairs from the first have been managed by a Council, composed of a President, Treasurer, Secretary, and 12 members, a portion of whom are changed each year. From among the other Members of Council the President now appoints four Vice-Presidents.

The total number of members elected in the year 1804 appears from the register to have been ninety-one. The Earl of Dartmouth was the first President; Mr. John Wedgwood, the first Treasurer ; and the Reverend Mr. Cleeve, the first Secretary, soon replaced by Mr. R. A. Salisbury.

In 1805 the meetings were transferred to the house of the Linnean Society, in Gerrard Street, Soho; the Horticultural Society paying 26l. 5s. a year rent, and engaging Mr. Price, the clerk of the Linnean Society, to act as their clerk also, at a salary of 20l. per annum. During the year it appears that the number of new members amounted to twenty-nine; but the early records of the Society are extremely meagre, and show little until the year 1806.

Judging from the scanty records which have been preserved, 
there would seem to have been little activity in the early proceedings of the Society; and the number of new members fell off accordingly. In 1806 there were but seventeen elections; in 1807 they fell to ten; and in 1808 were only eight.

On the 17th of April, 1809, the charter of the Society was signed by King George the Third, from which time forwards, the Society has existed as a CORPORATE BODY, with all the legal powers and privileges attaching to such an institution.

In 1810, the first number of the Horticultural Transactions made its appearance, a publication which ultimately extended to ten 4to volumes, replete with Horticultural information both theoretical and practical of the highest value, and from which writers on gardening subjects have not failed to extract a large part of their knowledge. The cost of publishing these deservedly celebrated volumes had in 1830 amounted to $25,250 l$; and they were not finally discontinued until the year 1848 .

The year 1811 was ushered in by the election, on the 1st of January, of the late Mr. Thomas Andrew Knight as President, vice the Earl of Dartmouth deceased; an event which had great influence on the future destiny of the Society; for Mr. Knight held his office for twenty-seven years, during all which time his unrivalled knowledge and active mind were directed incessantly towards promoting the true interests of Horticulture and especially of this Corporation.

At this time, however, the mighty war in which all Europe was engaged pressed heavily on peaceful occupations, and Horticulture seems to have shared fully in the general adversity. In 1809 the number of elections had been fourteen; in 


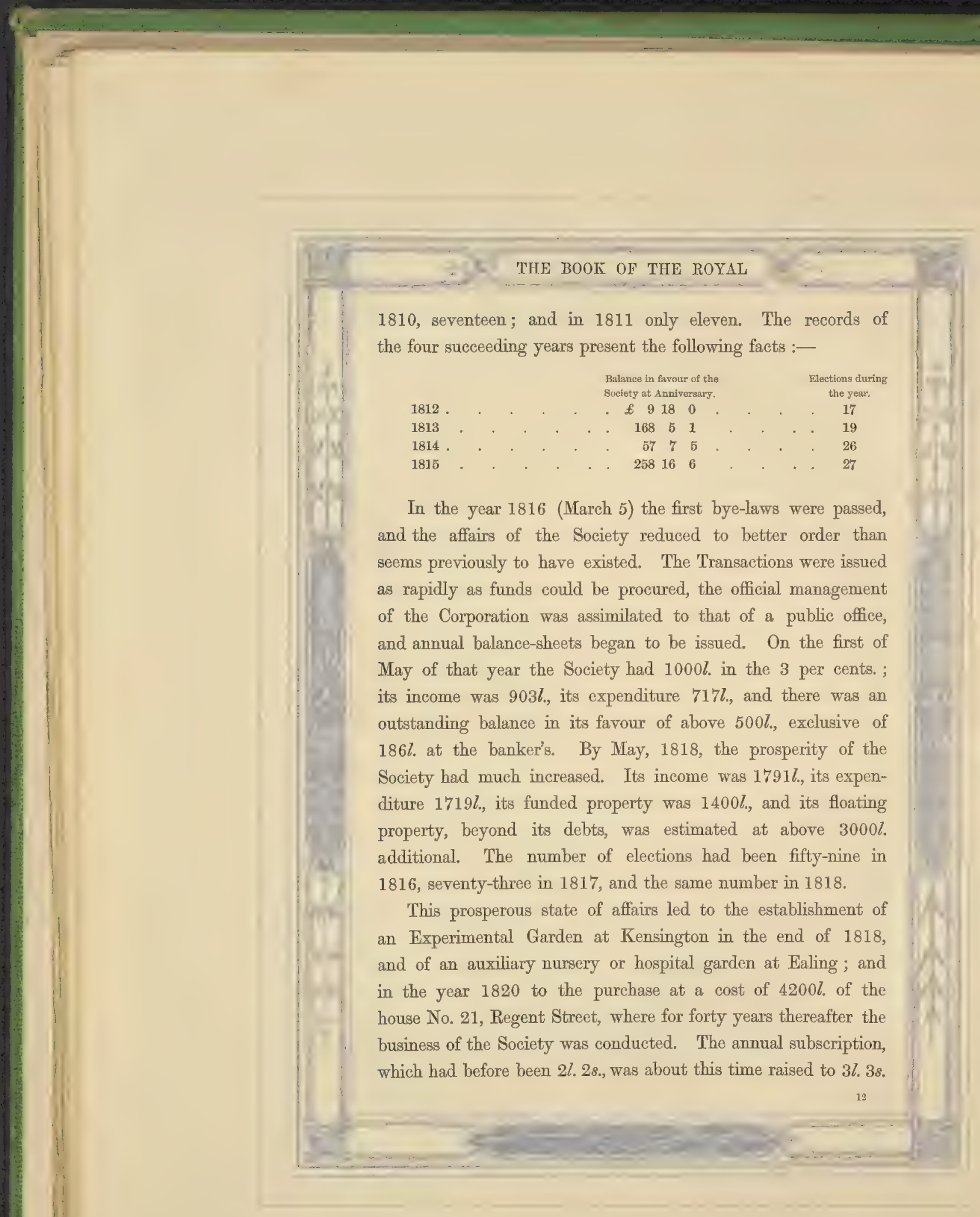




\section{HORTICULTURAL SOCIETY.}

Simultaneously the elections rapidly increased, having risen from 73 in 1818 to 220 in 1819,297 in 1820 , and in 1821 to 328 , the largest number ever added to the Society in any one year previous to its removal to South Kensington; nevertheless on the 6th of February, 1820, the admission fee had been raised from $3 l .3 s$. to $5 l .5 s$.

On the 21st of March, 1822, the Society obtained a lease of the present Garden at Chiswick, from the Duke of Devonshire, on terms which were then considered favourable. Its extent was 33 acres, and the rent $300 l$. a year, with a power of renewal for ever upon a fine of $450 l$. every thirty years. The experience of the first thirty years, however, was not such as to induce the Council to take advantage of this power of renewal, and they contented themselves with obtaining a renewed lease for an additional period of thirty years, so that its natural termination is now upon the 29th of September, 1881, the Society, however, having power to relinquish possession at any time upon one year's notice.

About this time the Society lost its first protector and friend, Sir Joseph Banks. By a subscription among a few members of the Society, an excellent portrait of Sir Joseph, from the pencil of Mr. Phillips, was placed in the meeting-room of the Society, and still remains in possession of the Society. From it has been copied the centre figure in the woodcut at the head of this chapter.

Upon taking possession of the ground at Chiswick, the old garden at Kensington and its auxiliary at Ealing were relinquished, and the new Garden established.

Shortly after the peace in 1815, the attention of the Society began to be turned to obtaining valuable foreign plants from 
extra-European countries, a system by which the Society has conferred inestimable benefits upon these kingdoms. In the accounts of 1819 and 1820 , appears for the first time a charge of 108l. 18s. $9 d$. under the head of foreign importations.

The Society's minute-books show that a distribution of imported seeds took place in the spring of 1818 , and that the formation of a collection of fruit-trees had even then commenced. Plants had also begun to arrive from China, where Mr. John Reeves, then a most zealous correspondent, and long a highly esteemed Fellow of the Society, had charged himself with the labour of shipping plants for England, and of causing drawings to be prepared under his own inspection. These drawings were eventually collected into a unique series of volumes of authentic representations of Chinese Vegetation. Importations from China in those days were attended by difficulties now unfelt: the true principle of constructing plant-cases was unknown; and it frequently happened not only that plants perished from the dryness to which they were exposed, but that the chests in which they were packed were unavoidably heaved overboard while the ships that carried them were labouring round the Cape of Good Hope. Perseverance and money, aided by the zealous cooperation of the East India Company's officers, overcame these difficulties, and the many varieties of Camellias, Indian Azaleas, Chinese Pæonies, Roses, Chrysanthemums, \&c., introduced by the Society, are constant reminders of their well-directed energies. Not the least important of these acquisitions was the Glycine (or Wistaria) Sinensis, of which the first living plant (still growing in the Society's Garden at Chiswick) was sent by Mr. Reeves and arrived in 1818. 


\section{HORTICULTURAL SOCIETY.}

Assistance has at all times, when required, been cordially extended to the Society by the various departments of Government. On the arrival of one of these Chinese consignments, the Lords of the Treasury directed that all plants, seeds, \&c., sent to the Society from foreign countries, should be allowed to pass the Custom House free from duty.

Welcome and liberal although the consignments of their correspondents were, the Society saw the importance of opening up new ground, and by exploring countries previously unvisited make an effort to obtain plants of greater interest and novelty than could be got through their correspondents residing in partially known districts. They resolved to send abroad collectors at their own cost. At first, as might be expected, their attempts in this direction were feelle and hesitating, but with success their scope expanded until they produced results which have affected the appearance of all England. Nowhere can a day's ride now be taken where the landscape is not beautified by some of the introductions of the Horticultural Society.

The first collector sent abroad was Mr. George Don, and the Lords of the Admiralty, on the recommendation of the Society, furnished him with a passage on board one of H.M. vessels, which was to touch on the West African coast, South America, and the West Indies; in order that he might prosecute botanical researches for the benefit of the Society at the places visited. They also gave Mr. John Forbes a passage on board a vessel which was bound for East Africa, and which was to touch in passing at Lisbon and the Cape of Good Hope. Mr. Forbes was landed at the mouth of the Zambezi, since so celebrated by Livingstone's exertions, then nearly wholly unknown; but unfor- 
tunately he soon died while going up the river, not, however, before he had enriched his country with several new and interesting plants.

Afterwards Mr. John Potts, on the recommendation of the Society, was sent out to China and the East Indies by the East India Company. His health not standing the climate, he returned to this country, but only to die. Mr. John Dampier Parks was next sent to China. He received much assistance from Mr. Reeves, and his mission proved useful.

In 1823, Mr. David Douglas was engaged on the recommendation of Professor Hooker of Glasgow, now Sir William Jackson Hooker, of Kew. It was at first intended to despatch Douglas to collect in Chili, but the disturbed state of the country there at that time caused this idea to be abandoned, and not to lose his services he was sent, as a temporary employment, to North America instead, to collect fruit-trees for the Garden at Chiswick. In this he was very successful, having been very cordially received by the fruit-cultivators in North America, who for the most part liberally supplied him with every variety he wished, and enabled a very correct estimate to be made of the fruit-trees cultivated in America, and a comparison instituted with those of our own country.

In 1824 he was sent to explore the Oregon territory and the River Columbia, the Hudson's Bay Company, as always, lending their liberal and powerful aid where it could be of service, and here he continued until the year 1830. Mr. Douglas's explorations here were undoubtedly the most useful and profitable, as well as successful, of any undertaken by the Society. The country was new and contained a vast number of unknown 


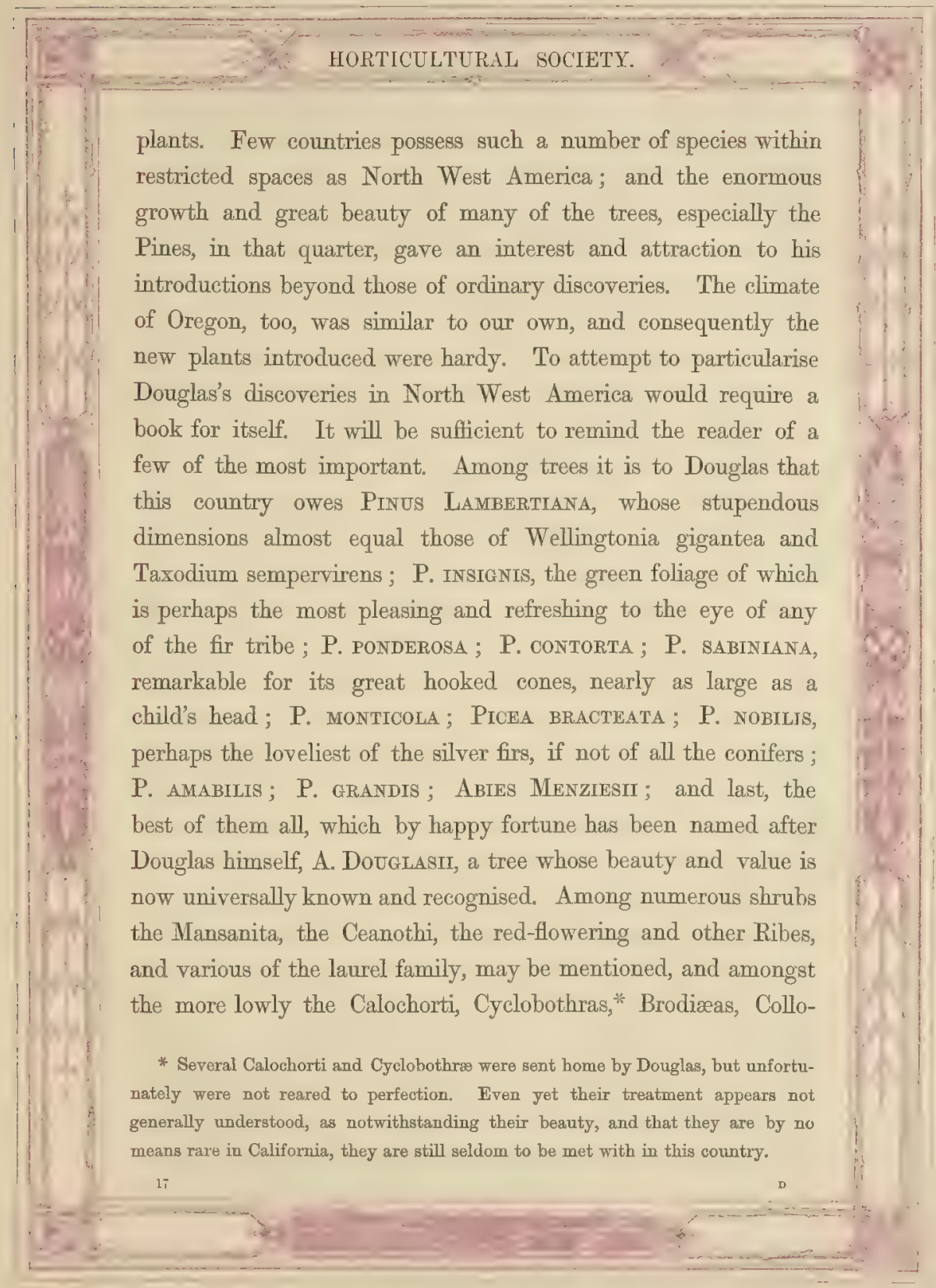


mias, Gilias, Gaillardias, Clarkias, Godetias, Collinsias, Lupines, Escholtzias, the musky Mimulus, numerous Pentstemons, and many other universal favourites in the Flower Garden.

Nor was this the sole or chief work done by the Society at this period. Between 1823 and 1830 its progress in works of permanent utility was continual and rapid. Series of experiments were instituted as to the best modes of cultivation, and collections made of many of the most important flowers and vegetables. In the year 1823 , no fewer than twelve hundred varieties of Roses existed in the Garden; and this assemblage, as well as the importations from China, may be assumed to have led to that elimination of bad sorts, and general improvement of the Rose, which has rendered the modern Rose-garden a scene of perpetual enjoyment, instead of a summer display which only lasted for a month or six weeks. An investigation of the value of the numerous foreign fruits and esculents had been undertaken after the conclusion of peace, and the confusion that existed among their names had been reduced to considerable order, as is shown by various papers printed in the Transactions, and by the Catalogue of fruits grown at Chiswick, the first edition of which appeared in 1826, and an improved edition of which is now (1863) in course of publication in the Monthly Proceedings of the Society. That system of heating glass structures by hot water, instead of by flues or expensive applications of steam, to which modern gardeners owe so much of their success, although it did not originate in the Garden, was first systematically applied there in the face of great opposition from those who objected to the introduction of a method to which they were unaccustomed; 


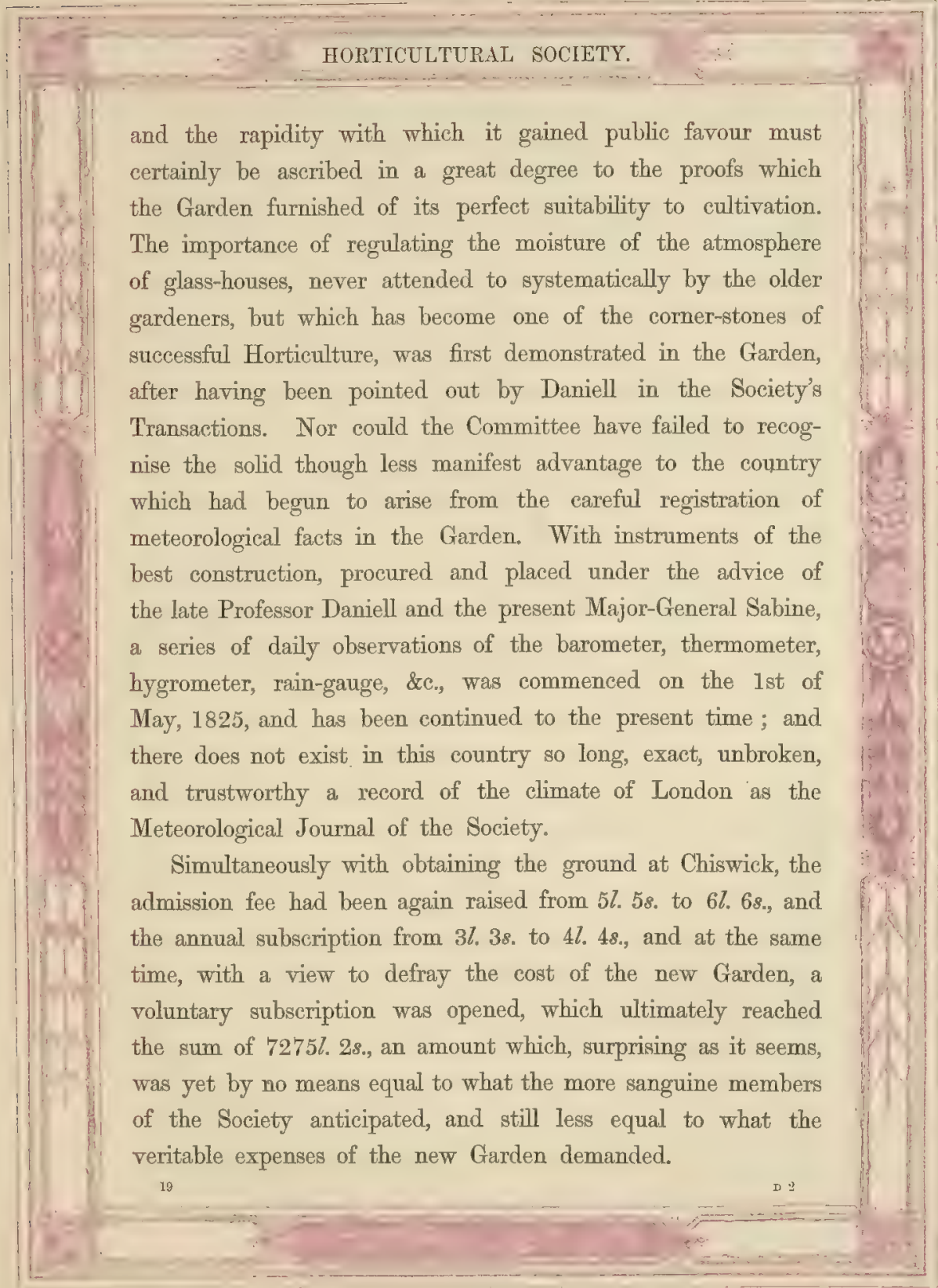


It is indeed very much to be questioned whether the undertaking so large and costly an establishment with no more surplus revenue than 18007 . (and this may be assumed to have been the Society's utmost means after the old Garden at Kensington and its auxiliary at Ealing had been relinquished), was acceptable to the Fellows generally; for although the resignations do not appear to have been much more numerous than usual, yet there was a greater number, and the very significant fact was observed, that the amount of elections during the first year of holding the Garden fell from 328 to 209, making a difference against the Society of 119; which was equal to nearly $500 l$. a year.

Unfortunately the falling off in elections did not terminate in 1823; on the contrary, not only did the annual balance of elections over resignations steadily diminish by the numbers $285,311,189,176,155,100,38,36$, between 1821 and 1828 , but it proved to be annually against the Society from 1829 to 1833 to the extent of $22,110,155,56,20$. This no doubt arose from several causes, the more important of which were the following :-

In the year 1826 it became known that a considerable sum of money belonging to the Corporation had been misappropriated by an officer who had absconded, leaving the Society a large loser by his defalcation. This created distrust, and immediately reduced the elections, which had been 126 in the previous year, to 88 .

Further, it had hitherto been the practice to hold an anniversary dinner annually in London, at which the Fellows met and cemented by moderate conviviality the friendship begun 


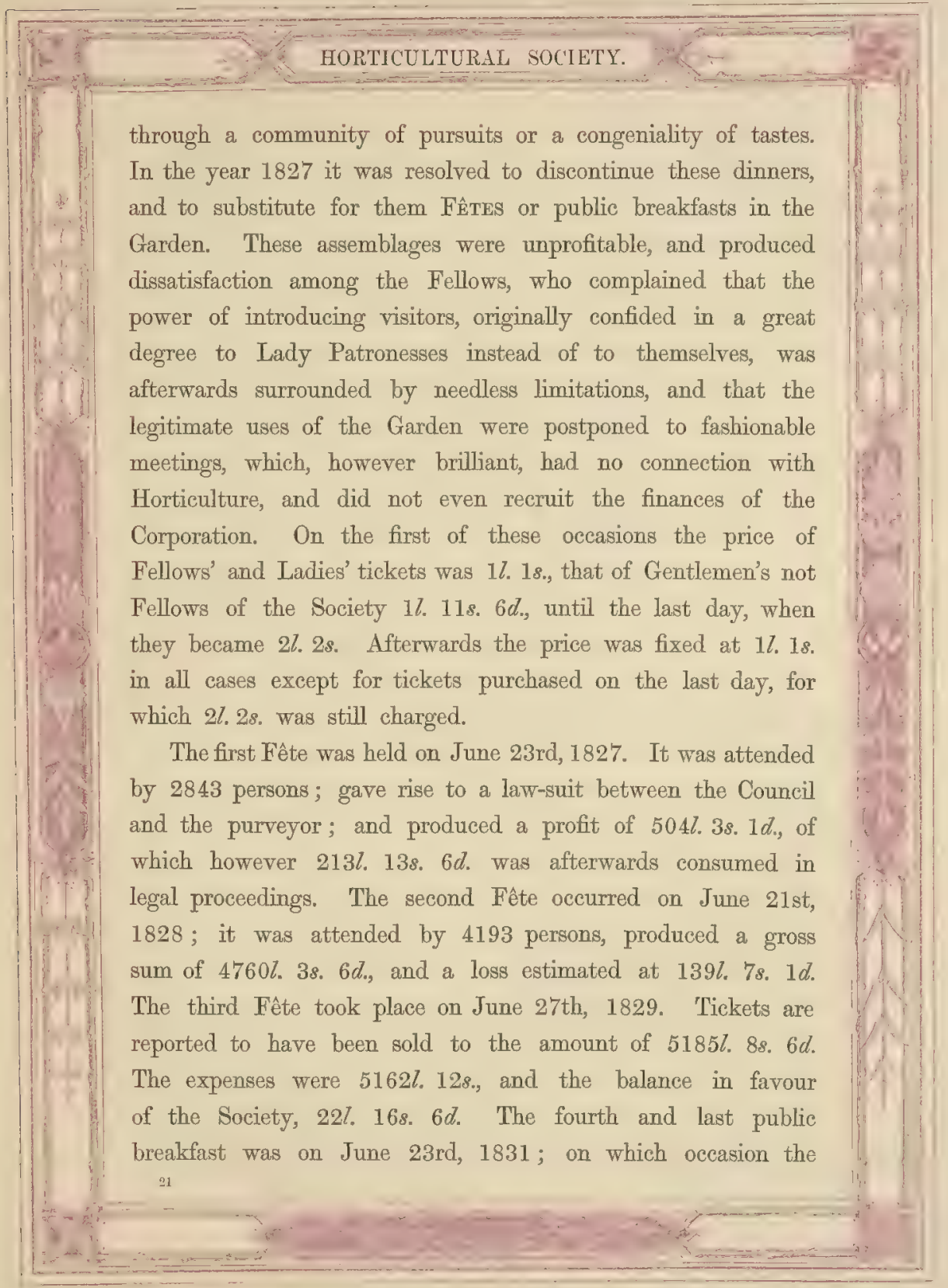


balance in favour of the Society was finally ascertained to be $115 \%, 12 s$.

It can hardly be said that these experiments were altogether unsuccessful, for although at the time they certainly were so, if viewed merely as financial speculations, yet they shed a lustre over the Society of which it feels the benefit to the present day. In consequence, however, of the want of pecuniary success attending them, they were abandoned, and replaced by the Garden Extibitions, which from that time forward have formed a prominent feature in the history of the Society. It is chiefly to Dr. Lindley that the Society and the world owe the idea of these exhibitions, which not only proved a source of profit and renown to the Society, but have been the means of delighting and improving thousands who have thronged its exhibitions, and those of the numerous societies all over the world which have followed its example.

By the year 1826 the heavy charges incurred in the formation of the Garden had begun to affect seriously the pecuniary resources of the Corporation. The large revenue derived from the sale of the Horticultural Transactions began to fall off, annual receipts of other kinds had not increased in proportion to the Garden expenditure, and the floating debt had acquired such formidable dimensions that the Councils ceased to lay before the Anniversary Meetings any account of debts and liabilities after May, 1826. In addition to these sources of embarrassment, differences arose between some Fellows of the Society and the then Secretary, Mr. Sabine, which finally led to the appointment, on the 2nd of February, 1830, of a CoMmrTteE of EvQuiry, which was authorised to investigate " the income and expenditure, the 


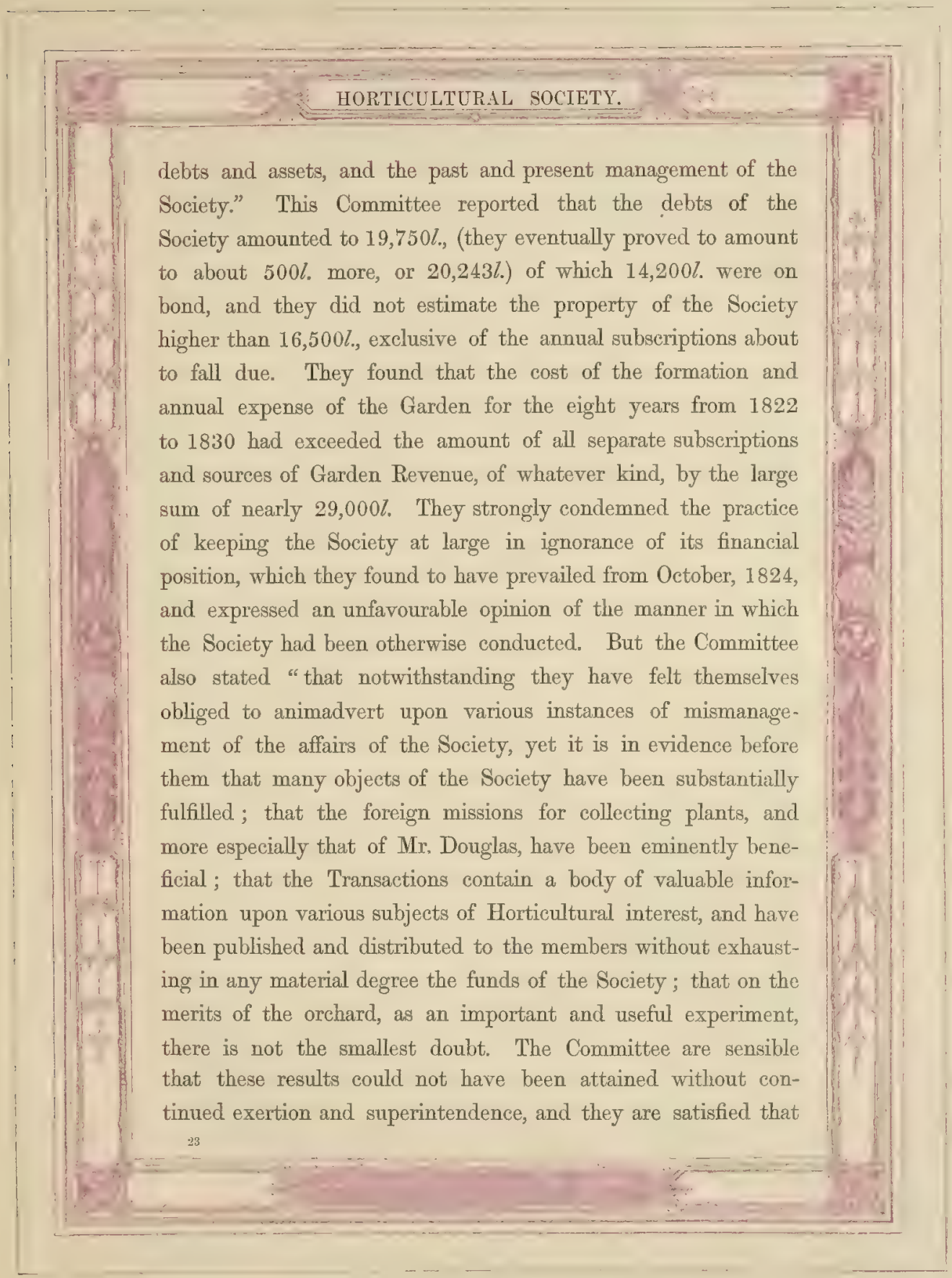




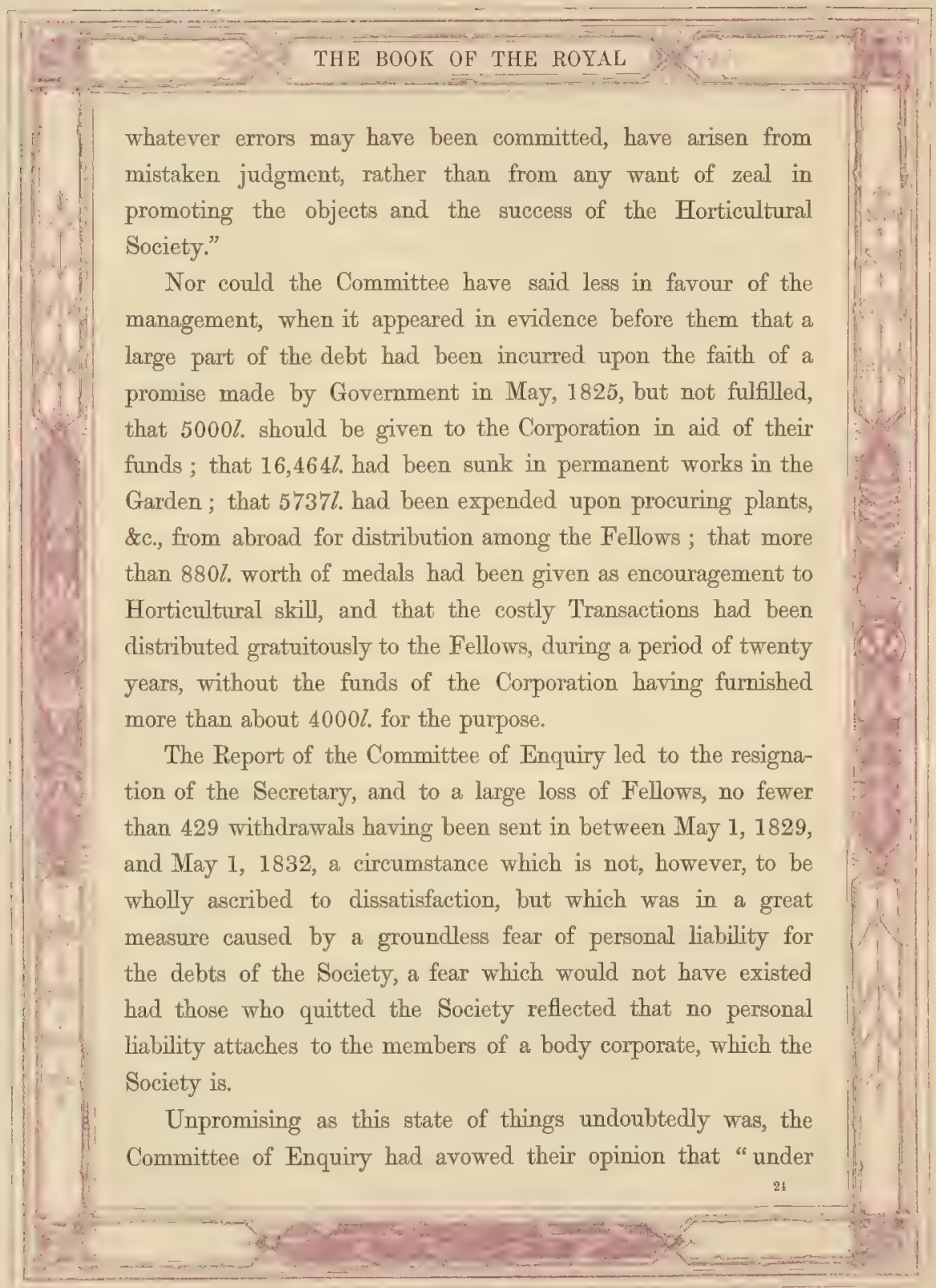




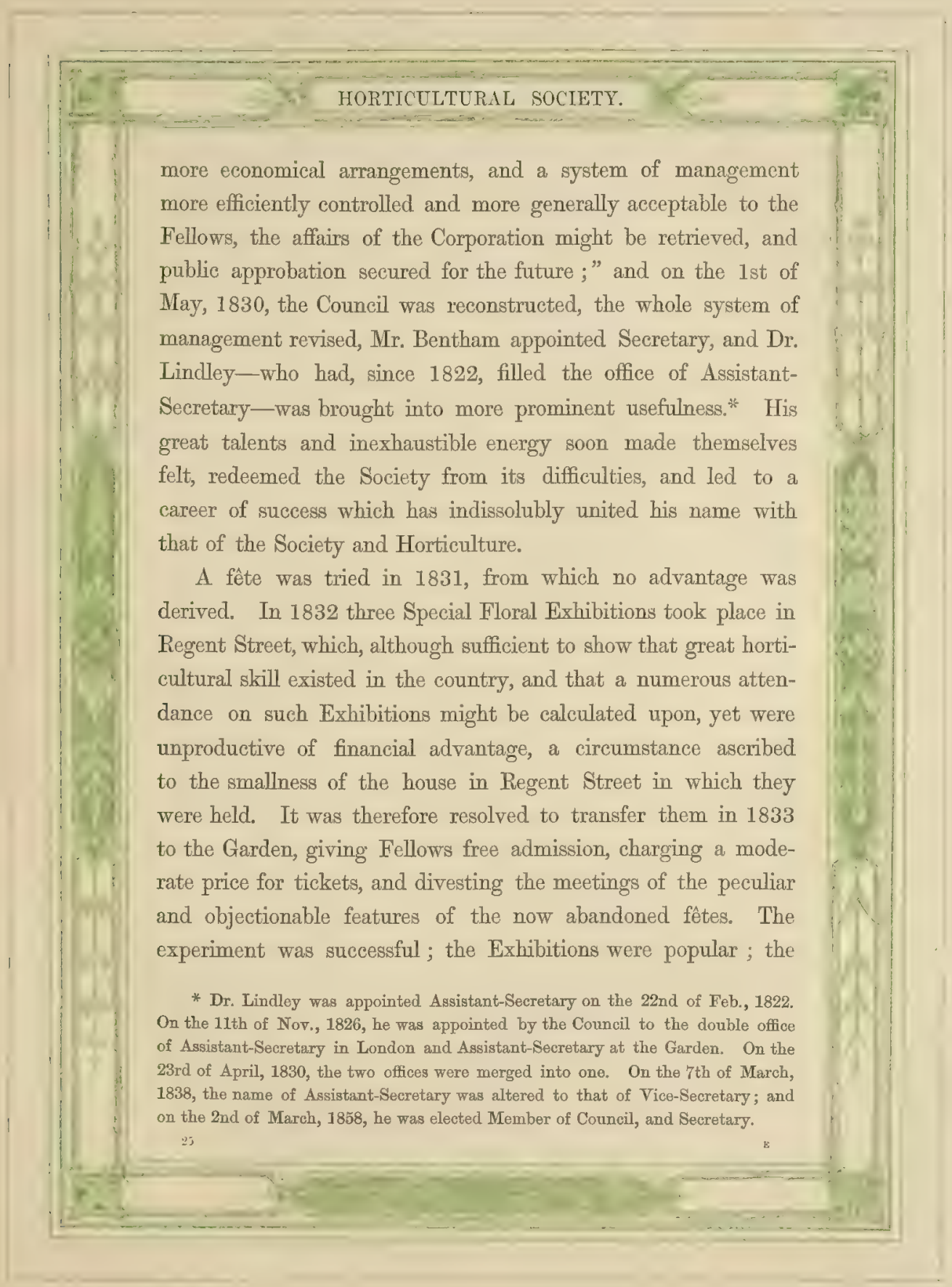


number of elections began to increase. Since that time the Garden Exhibitions have produced an important part of the annual income of the Society. The largest sum carried to account, prior to 1862 , was in 1844-5, when it reached $3024 l$.

With such means at command the incumbrances of the Society could have been readily liquidated, had there been no other purpose to gain than that of paying off liabilities. But it was obvious to each successive Council that, however necessary to the welfare of the Society extrication from debt might be, they were entrusted with the management of the Society for other purposes. A part of the debt dated as far back as 1824 ; the whole of it was incurred before 1830 ; and it seemed unjust to the Fellows elected since that time to apply the funds supplied by them to no other purpose than the discharge of debts, to contracting which they had in no way been parties. Nor could the various Councils avoid feeling that progress was indispensable to the existence of the Corporation, and that to discontinue the improvement and encouragement of Horticulture would be virtually to abandon the purposes for which alone the Society was incorporated. They therefore endeavoured to combine, as far as possible, the liquidation of the Society's liabilities with a vigorous prosecution of the objects declared in the charter. Hence, in the years which elapsed between 1830 and 1855 nearly $11,000 l$. was expended in works of permanent utility in the Garden ; and more than 7000l. in the introduction of rare plants and seeds by collectors and correspondents abroad; notwithstanding which the debts were gradually reduced to $5000 l$. bonded, and $3800 l$. floating. In the course of this time the high character of the Society was also sustained, not 


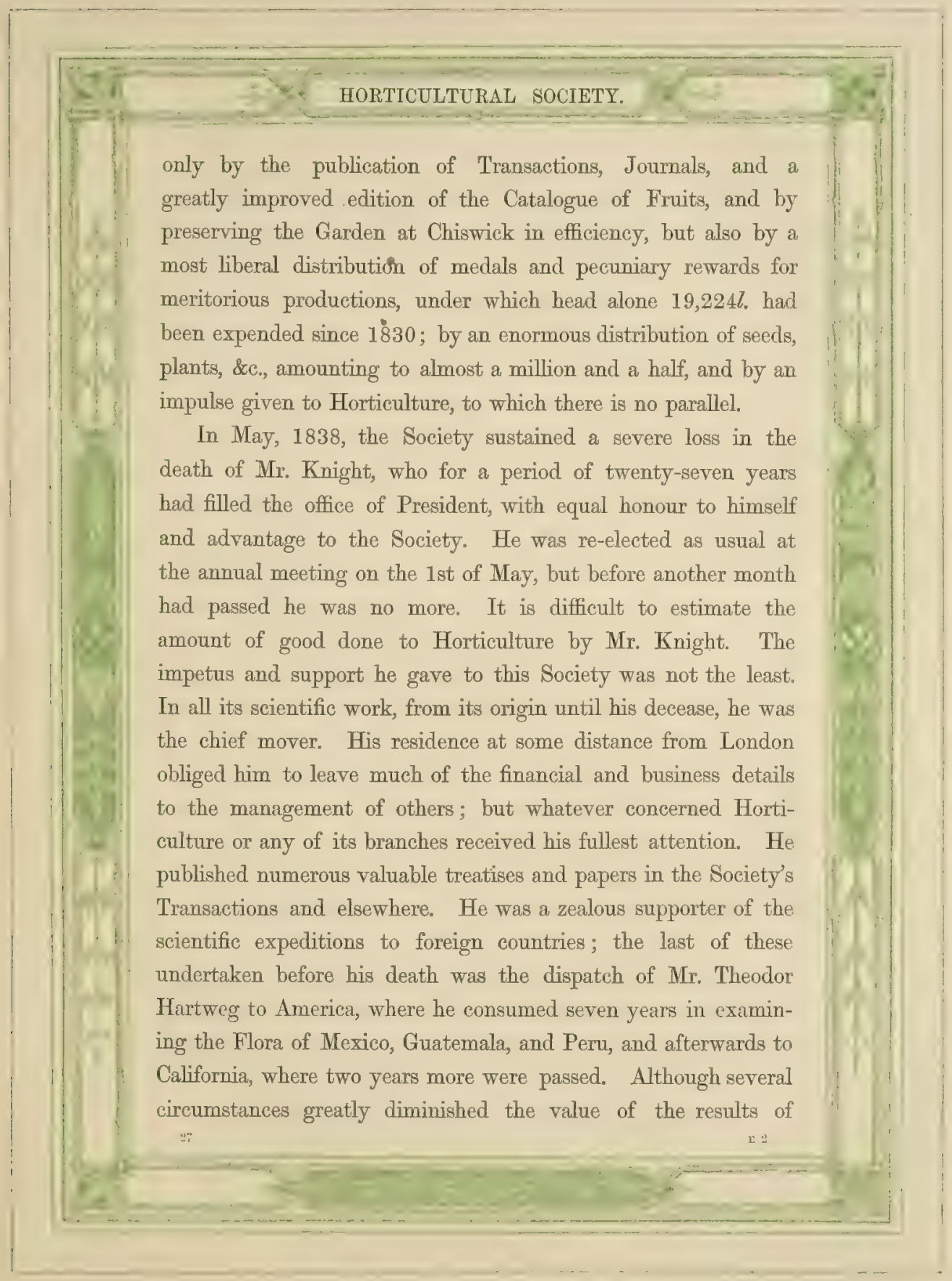


Several cases of living plants likely to prove useful to the inhabitants were sent out under Mr. Fortune's charge, as well as a large quantity of vegetable and flower seeds, the greater part of which arrived in good order, and have proved of permanent benefit to the inhabitants around the northern ports of China. Mr. Fortune's operations were equally beneficial to this country. To them we owe some fine varieties of Prunus and Viburnum, Spiræa prunifolia, Gardenia Fortuniana, Anemone japonica, Chusan palm, Abies Kœmpferi, Pinus Bungeana, Campanula nobilis, Berberis Fortuni, Buddlea Lindleyana, the white variety of Glycine sinensis, Daphne Fortuni, Citrus japonica, Weigela rosea, Jasminum nudiflorum, Forsythia viridissima, Cryptomeria japonica, and the charming rosy Dielytra spectabilis.

Nor must we forget many interesting varieties of Azaleas and Roses, with Moutans of colours (dark purple, lilac, and deep red) not previously known. The small Chrysanthemum, which he named the "Chusan daisy," and which has become the parent of the new race called pompones, was also the product of this expedition.

Many of Mr. Fortune's discoveries on this occasion were made in the green-tea districts of China. During his researches he had an opportunity of making himself acquainted with the cultivation and manufacture of tea, and many other matters relating to the horticulture and agriculture of the Chinese, and he published an account of these in a personal narrative of his travels.* The knowledge he had thus acquired, shortly afterwards led to his being employed by the East India Company to carry out their attempts to establish that branch of industry in

* "r Three Years' Wanderings in China." 
their North-Western Provinces, the suecess of which is now matter of history-so that the influence of the Society's operations extended far beyond their own sphere-they not only did good themselves, but were the eause of others doing so likewise.

All this was effected, notwithstanding very considerable disappointments in the realisation of funds which ought to have been available for the purposes of the Society. From the very beginning there had been a difficulty in obtaining payment of subscriptions. As early as 1806 the evil was sensibly felt; at a later period, in 1815, no less than 1000l. was claimable from Fellows who neglected to fulfil their obligations; and it appears that between 1824 and 1855 no less a sum than 12,879l. 12s. from this source had been abandoned as irrecoverable.

Up to the year 1851-2, a pretty steady reduction of debt, sometimes large, sometimes small, continued to take place; but the tide then began to turn. For the next three years the debt gradually increased, chiefly from the falling off in the number of admission fees and the diminution in the receipts from Exhibitions.

In fact, the Society had been sustained by its Fixhibitions for some years previously. Its yearly income and expenditure had been on an average above $7000 l$, but its regular income from annual subscriptions did not exceed $3000 \mathrm{l}$, and allowing 2000l. a year for the cost of the Exhibitions, there remained an excess of expenditure over income amounting to $2000 l$. So long as the Exhibitions prospered and made good this return, all went well. But if any check were given to these, if even for a single year the revenue drawn from them should fail, the consequences must be serious. Such a reverse seems never to have been 


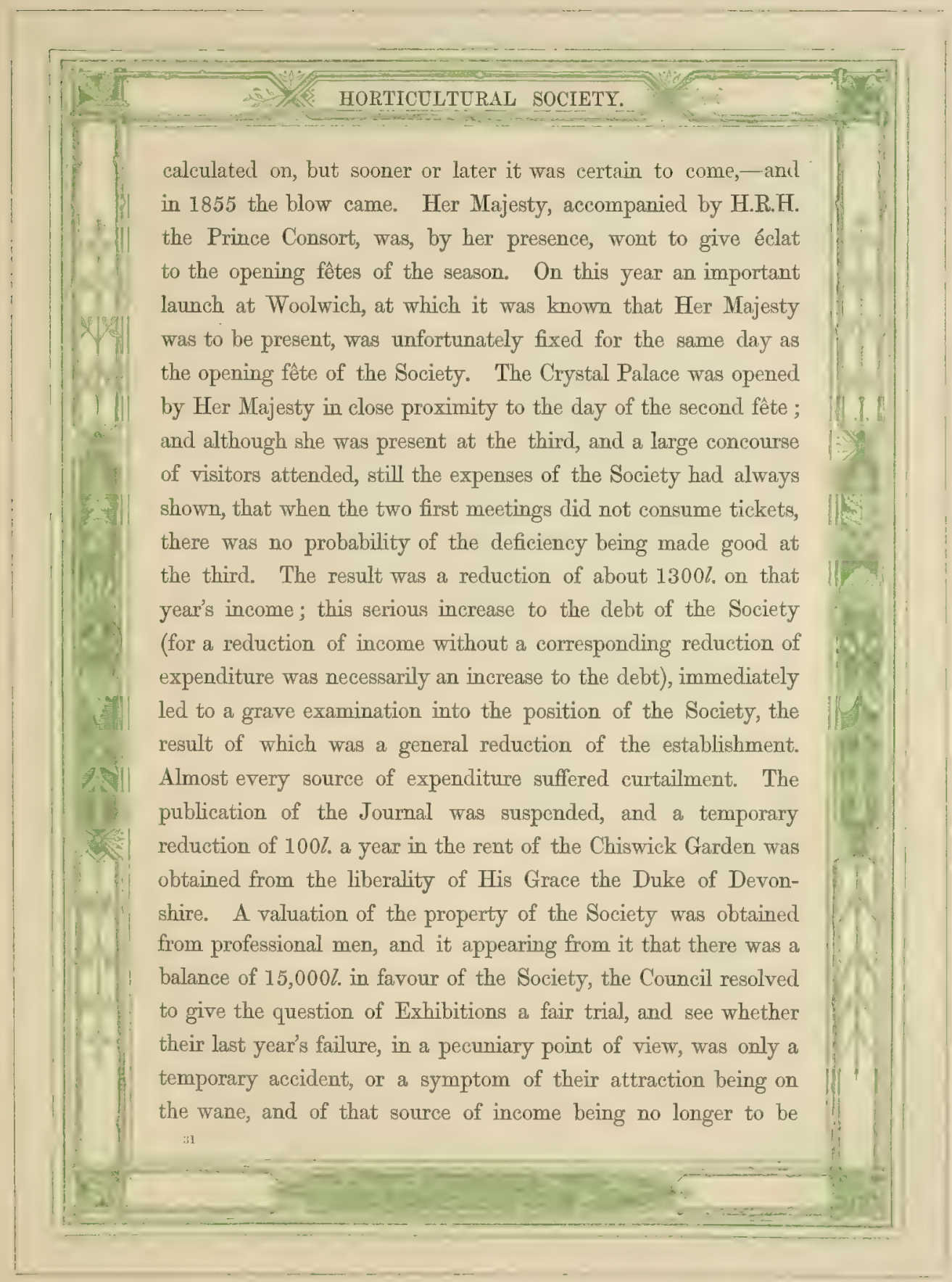


depended upon. They also introduced Meetings at the House in Regent Street, and made every effort to make them as attractive in their way as the great assemblages at the Garden. With this view they increased largely the number of medals and other awards bestowed on these occasions, and invited the production of every valuable subject connected with gardens, which might be either remarkable for novelty or intrinsic excellence. Much interest was added to these collections or exhibitions by explanatory lecturettes (as they were called) which were given by Dr. Lindley. These still dwell gratefully in the memory of those who listened to them, and their cessation forms one of the most frequently expressed regrets of the laudatores temporis acti.

The Duke of Devonshire, who had been elected President on the death of Mr. Knight, lent his powerful aid. On the oceasions of the great meetings at Chiswick he threw open the adjoining grounds of Chiswick to the Society and their visitors, and the promenades on its charming lawns and under its ancient cedars drew thousands of the world of fashion to these privileged fêtes.

The trial, however, was only partially successful. The house in Regent Street was amply supplied with valuable specimens of horticultural skill, and a large number of visitors availed themselves of the opportunity to examine them. Other efforts were made in various directions. Changes were made in the meetings at the Garden, both as regards arrangement and the rewards to be conferred. But matters were not restored.

For many years the Exhibitions at the Garden were accompanied by such constant fine weather that precautions against rain seemed needless. From 1833 to 1843 , a period of eleven 


\section{HORTICULTURAL SOCIETY.}

years, only two afternoons out of thirty-three were wet, and of these one was very slightly so. In 1845 and 1846 every day was fine; but after that time a change seemed to have taken

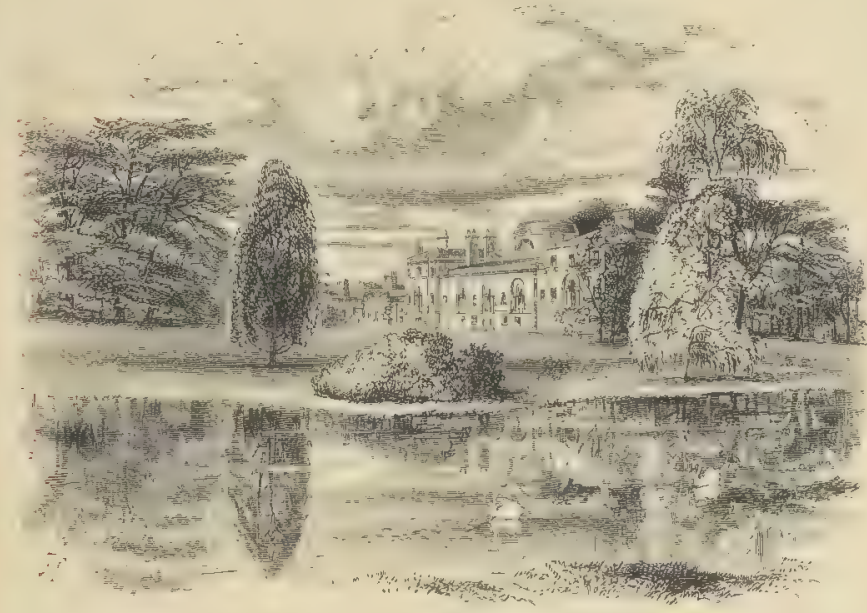

place in the weather in May, June, and July, and out of nine meetings in 1847,1848 , and 1849, five were more or less stormy. The inconvenience and discomfort arising from wet weather to great assemblages of people drawn together for enjoyment in the open air can searcely be exaggerated,-no amount of protection by way of tents can render them bearable; and of those unhappy occasions when Jupiter Pluvius reigned supreme many a miserable anecdote might be related. On one of these occasions, before the practice of giving the so-called breakfastfêtes had been abandoned, the day turned out unpropitious. Large numbers of tickets had been disposed of, which had cost 3 


\section{THE BOOK OF THE ROYAL}

not only $2 \% .2 s$. a head, but also much expense of interest among the exclusive Lady Patronesses who dispensed them. The tickets were thus too valuable to be thrown away, and the majority of their holders braved the bad weather in the hope of its clearing up. On the part of the Society nothing had been omitted to make the entertainment worthy of itself and the expected guests. Ample tents and temporary wooden buildings had been erected, and all the resources of Messrs. Gunter brought into play to provide the feast. Gorgeous plate, fine china, and sparkling crystal, combined with the most delicate viands and high-priced wines to charm the eye and tempt the palate. What the morning promised-(a wet day) - the noon fulfilled, and the weather settled into confirmed rain; and as the hours wore on, it grew worse and worse, and the rain fell heavier and heavier. Still the possessors of the much-prized tickets made their appearance. Carriage after carriage deposited its fair and gaily-dressed freight at the gates, * whence ushered into the tents they endeavoured to drown the splashing of the rain on the roof by the loud harmony of military bands, and to forget their discomfort in the enjoyments of the table. Many and strange were the scenes that passed: the tents were open in front, and the driving rain eame pelting in-the canvas roof soon distilled drops or streams at many places-the ladies as they sat or stood found the water invading their shoes; the ingenuity of the gentlemen came to the rescue-some of the ladies were placed on the table-the dishes were emptied of

* The cavalry made a good harvest on this day. They lent their long heavy military cloaks to the ladies, to protect them on their passage from their carriages to the tents, at $2 s, 6 d$, each. 


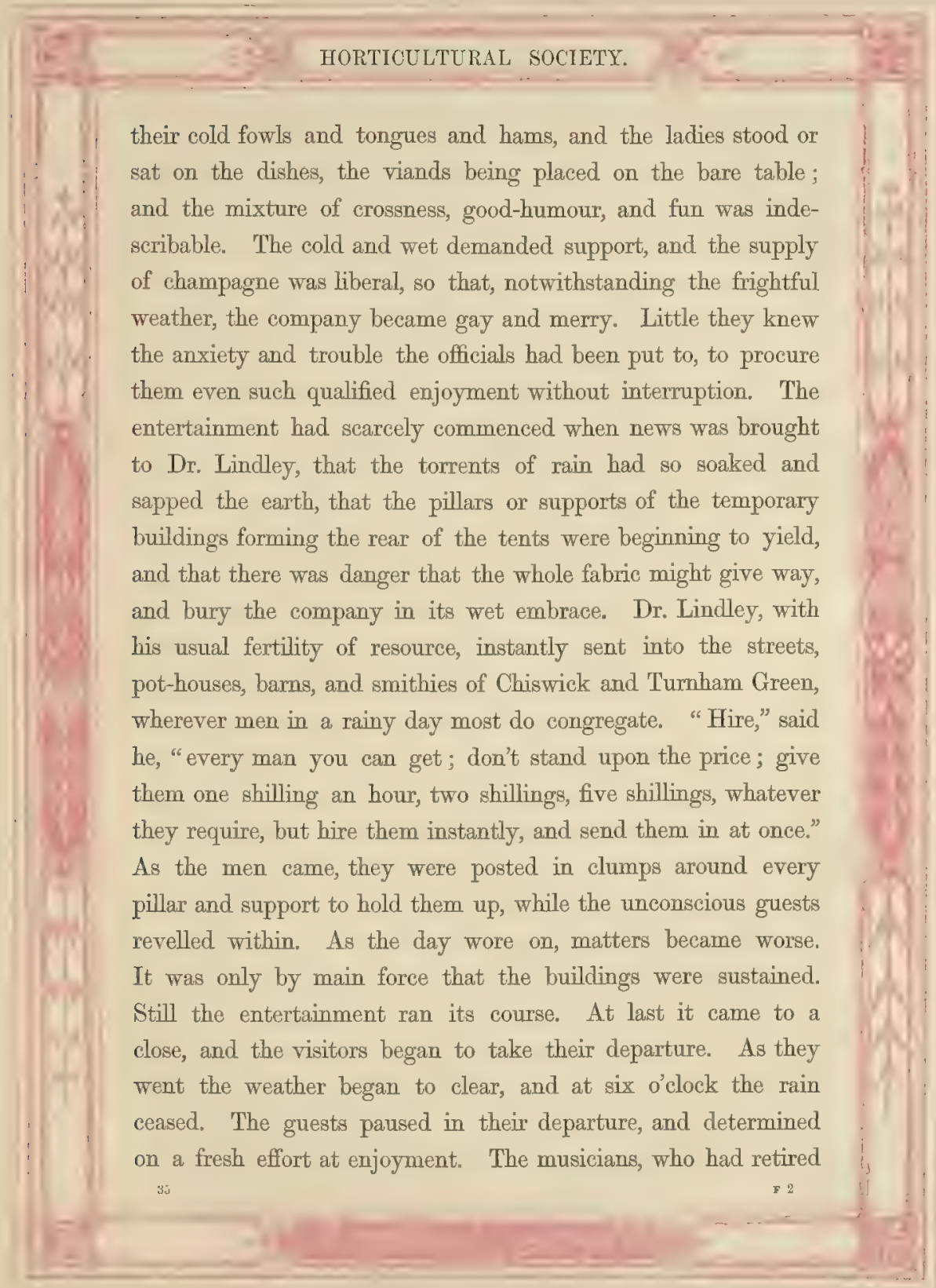


to obtain their own refreshment, were recalled from the publichouses to which they had retreated, in order to enable the guests to terminate the fête with dancing; and on the wet and splashy grass dancing was for some short time kept up. This, however, soon ceased-dancing in soaked boots and shoes* on wet grass not being an amusement capable of long enjoyment-and at last the day's entertainment came to an end. No sooner had the last visitor taken his departure, and the men been released from their long and laborious duty, than the posts and pegs at the back of the tents and buildings slowly yielded, ploughing through the muddy puddle in which they stood, and the whole fabric gave way with a crash, burying in one undistinguishable ruin the tables, and the dinner-service, wines, and viands under their wet and heavy folds. "What are we to do, Sir?" cried the panic-stricken servants. "Let them lie until Monday," was the reply; and so they did, and longer than Monday. It was a fortnight afterwards before the purveyors got all the articles, overwhelmed on that night, removed. And it is noteworthy and to the credit of the Society's servants, that although the whole appareil of the feast-broken crystal, and viands-lay mixed with valuable plate for so many days, not a single article was lost. The spoons and forks were recovered by raking them out of the mud, and not one was missing.

Such accidents as this, or even the risk of such misfortunes, rendered the Council, when they saw that the seasons or their

* There is a tradition that a bushel of wet shoes and stockings was picked up in the Garden and neighbourhood next day, probably thrown from the carriage windows after the owners had obtained fresh supplies from the Chiswiek shops on leaving. 


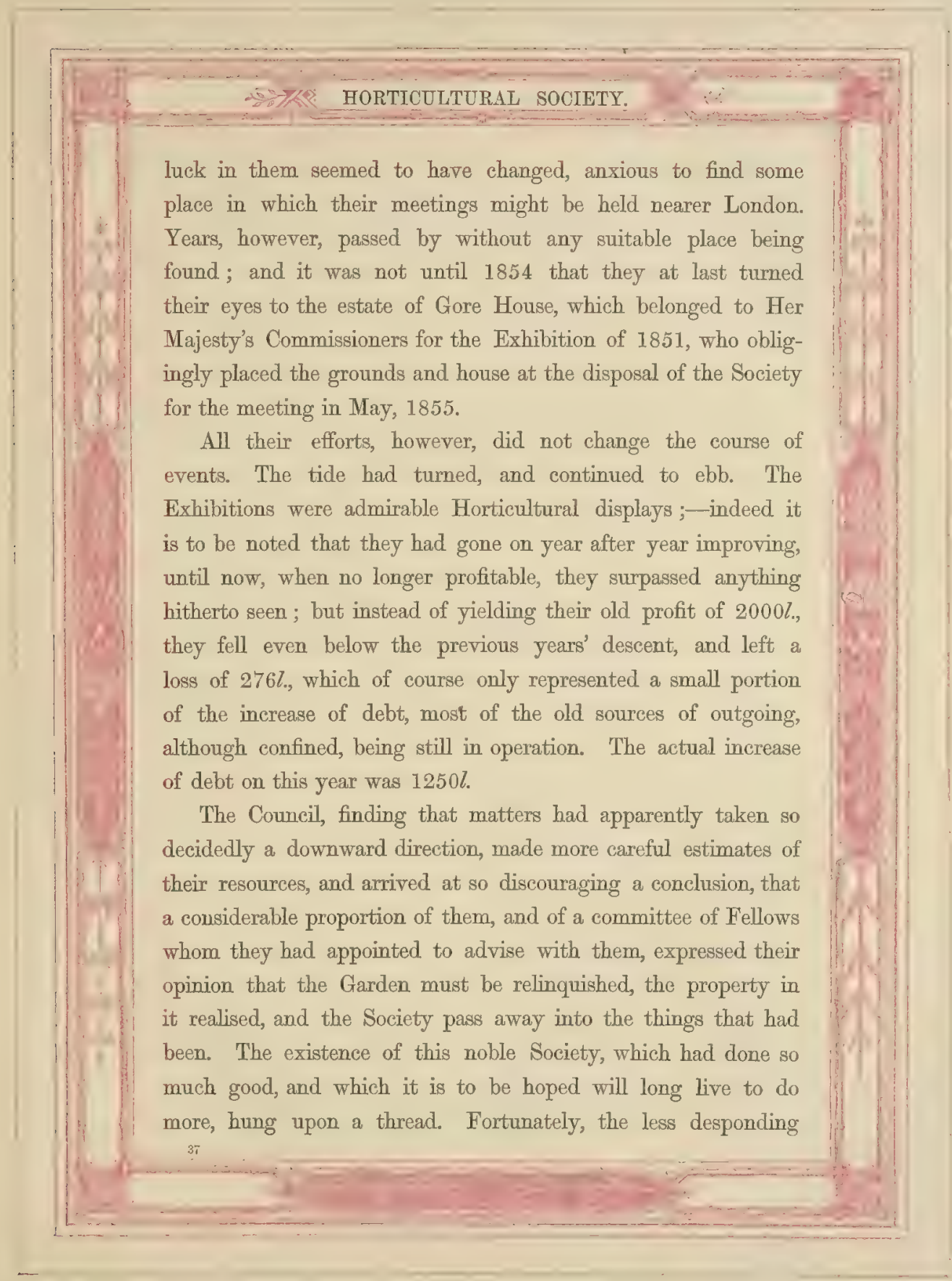


element preponderated in the Council, but so strong was the impression against its recovery that a circular letter was sent to every Fellow, stating that the Council had arrived at the conclusion that the Garden exhibitions would not be profitable in future, and proposing to revert to the system followed in 1821, when the Society was in its most flourishing state, at which time its operations were confined to the encouragement of horticulture by rewards, and the publication of its Transactions; to exhibitions in London; to the distribution of seeds, \&c., obtained from its correspondents; and to the maintenance of a small and inexpensive garden.

Special meetings of the Society were held to consider the state of matters, and much and keen discussion ensued as to the propriety of retaining the Garden at Chiswick. Some were for terminating the lease of Chiswick as soon as its conditions would permit, selling the property of the Society, and carrying it on by smaller exhibitions in London. Others were for selling off everything at once, paying off the value of the Life Compositions, and winding up the Corporation. Others again suggested removing the Gardens to the Crystal Palace grounds, and making some mutually beneficial arrangement with that body. But the majority resolved to make another effort to preserve the Garden at Chiswick, which by many was thought tantamount to the Society itself,-- the two at that time being supposed to be like Siamese twins, indissolubly linked together. An appeal to the Fellows and the public for subscriptions for this purpose was resolved upon. This was liberally responded to, although not quite to the extent required or expected. 3267l. was subscribed by 181 individuals, and to show the light in which the Society 
was looked on by the general public, it may be mentioned that sixteen of these subscribers were not Fellows, and one of them, Heinrion Behreins (let his name be honoured), a German gentleman, subscribed no less a sum than $100 l$. The subscription was considered so far satisfactory that the relinquishment of the Garden at Chiswick was at least postponed for another year. Meantime the establishment was still further reduced; the collector in Mexico was recalled; the culture of stove plants was abandoned, and the plants themselves were sold, bringing about 569l. The Herbaria of the Society, consisting of the original species sent home by the Society's collectors, and which formed the types of many of the plants newly introduced by them, and described by Dr. Lindley and others, were sold for 253l. This was a sacrifice greater in appearance than reality; the Society not being a Botanical Society, they were seldom consulted, and it was perhaps better that they should be, as they were, secured to Science in the great national collections of the kingdom.

Fortified by the amount of the subscriptions, and the encouragement received from various quarters, the Council received power from a General Meeting "to take such measures for the reorganisation of the Society as they might consider advisable, even though those measures should involve the relinquishment of the Garden at Chiswick, and the realisation of the property or any part of the property therein."

Under this authority the Council made various alterations in the rates of subscription and privileges of the Fellows, reducing the former and increasing the latter. They made an application, which turned out unsuccessful, to Government for apartments 


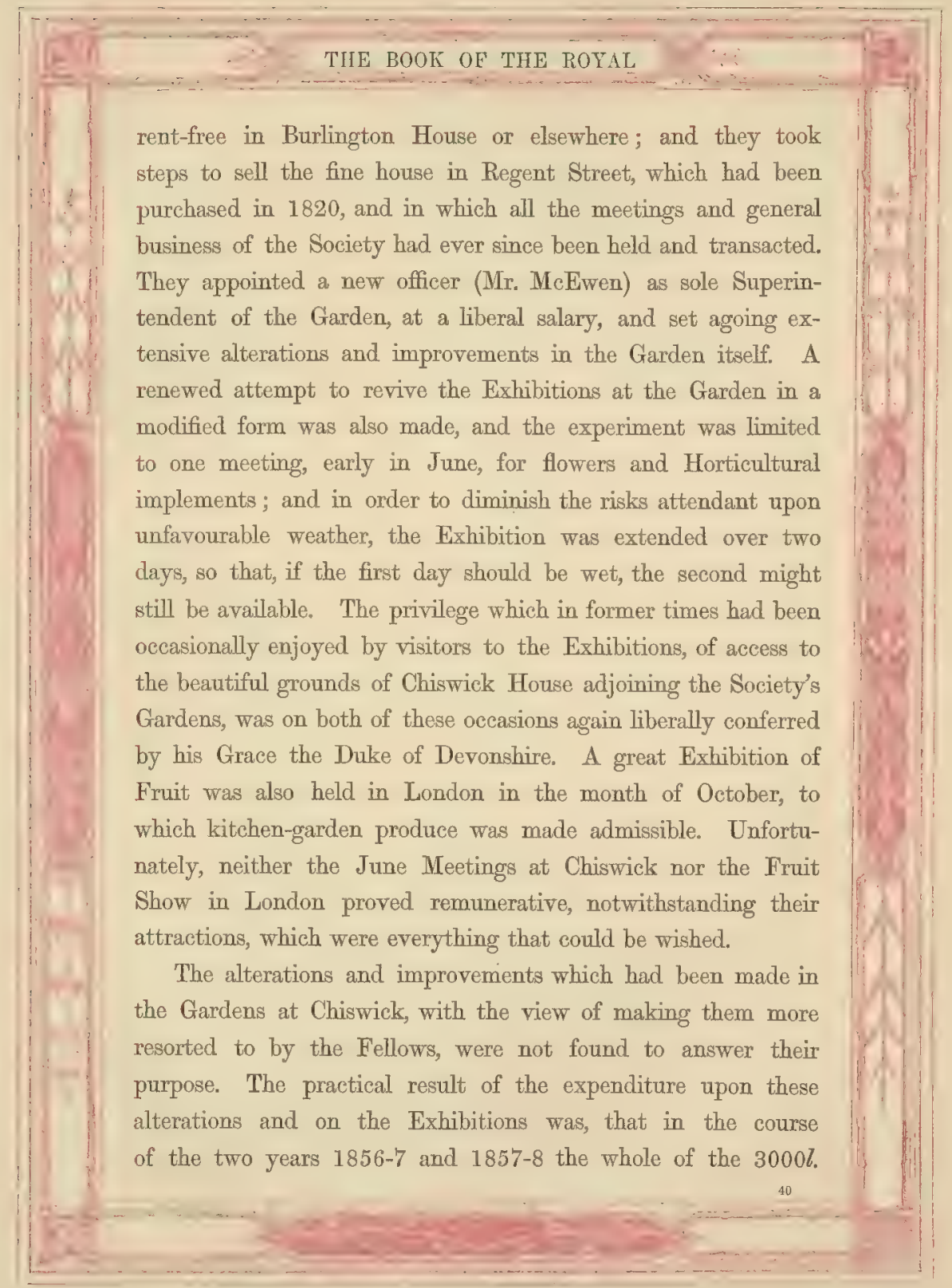




\section{HORTICULTURAL SOCIETY.}

subscribed to relieve the Society from its embarrassments had been swallowed up, and the debt of the Society remained precisely where it was before the appeal to the Fellows and the public had been made. Notwithstanding this, and notwithstanding the failure of the Exhibitions in a pecuniary point of view, the Council in 1858 , believing such meetings to be essential to the prosperity of the Society, and perhaps misled by an accession of 300 new Fellows during the past year (185\%), resolved to continue them; and having found what seemed a suitable place for holding them, in St. James's Hall, a new building in Piccadilly, they held three great Meetings there in 1858, which again resulted in a further loss of upwards of $500 l$., notwithstanding the patronage and presence of Her Majesty and H. R. H. the Prince Consort. The influx of new Fellows did not continue during the year 1858. At the anniversary on 1st of May, 1857, the total number of Fellows of all classes, augmented by the additions of the previous year, amounted to 978 ; on 1st May, 1858, they only amounted to 985 , the deaths and resignations having all but neutralised the addition of 62 new Fellows.

The debt had now again risen to nearly $10,000 l$, and the Council felt that matters had reached a crisis when half measures would no longer be of service.

Whether wisely or not, the steps they took were those of brave men, looking their calamities boldly in the face, and, without shrinking, using such means as were in their power (however distasteful) to meet them. Their first step now was to provide for the most pressing claims. This was done by the interposition of their personal security and liberal advances by way of loan by the wealthiest or most zealous of the Council.

41 
Nothing more could be done in the way of reduction of expenditure. They had already reduced the Society's establishment to its lowest working point. Dr. Royle, who had for seven years filled the honorary office of Secretary, having died in $\mathbf{1 8 5 7}$, Dr. Lindley had resigned the paid office of Vice-Secretary, which he had filled with so much distinction since 1830, and been elected to the Honorary (unpaid) office of Secretary in Dr. Royle's place: The Vice-Secretaryship was not filled up. Their next step was, therefore, to realise the property of the Society, so far as this could be done, without stopping its action. The house in Regent Street, which had been the focus of Horticulture for so many years, was disposed of for $3000 \%$; and in place of it a small office was taken in Trafalgar Square, consisting of one room and lobby or ante-room, at a rent of $80 l$. a-year; and to crown all, the magnificent library, which had been growing during a period of forty years, until it was now one of the finest Botanical libraries in the world, and which, moreover, contained a multitude of original and typical drawings, was brought to the hammer and dispersed beyond recall.

Alas! how short-sighted are we all! Could the Council but lave foreseen what two short months were to bring forth, they might have 'spared themselves this unnecessary sacrifice. And yet, even now, when we know all, although. unnecessary, at least it cannot be called a useless sacrifice. It, and the liberality of the Members of Council, cleared the way for the plans which followed. They paid the debts and restored the credit of the Society, and so removed difficulties in the way of the subsequent arrangements which would otherwise have been hard to overcome. Be this as it may, within two months of the date 


\section{HORTICULTURAL SOCIETY.}

of the Report in which the Council announced these acts of despairing energy, another special Meeting of the Society was called (held on the 7th of July, 1859), at which propositions were made which wholly altered the aspect of affairs, speedily restored the Society to more than its former vigour, within two years reared the beautiful Arcadian Garden at South Kensington, and opened to it a career of extended usefulness, surpassing, we may hope, even the brilliant success of the old Society. To this we must devote another chapter, but, before leaving the history of this epoch, we may be allowed briefly to sum up the work done during it by the Society, and the benefits conferred by it, not on this country alone, but on mankind in general. We cannot do so better than by quoting the words of the Council in their Report on 1st of May, 1857:- "For more than half a century, the Society has endeavoured to pursue the path traced out by its Charter. It has minutely examined the qualities, and reduced to order the names, of fruit-trees and of esculent plants; it has directed the attention of scientific as well as of practical men to the improvement of the arts of cultivation; it has introduced at much cost great numbers of exotic plants to decorate our gardens; it has published many volumes filled with important treatises upon almost every subject in which the gardener is interested; it has formed a very extensive garden and orchard, in which bave been collected from time to time numerous plants, valuable for their utility or beauty; it has given a great impetus to cultivation by its public exhibitions of garden produce; it has been a school from which have sprung some of the most distinguished gardeners of the present century; and it has given away to its Fellows 


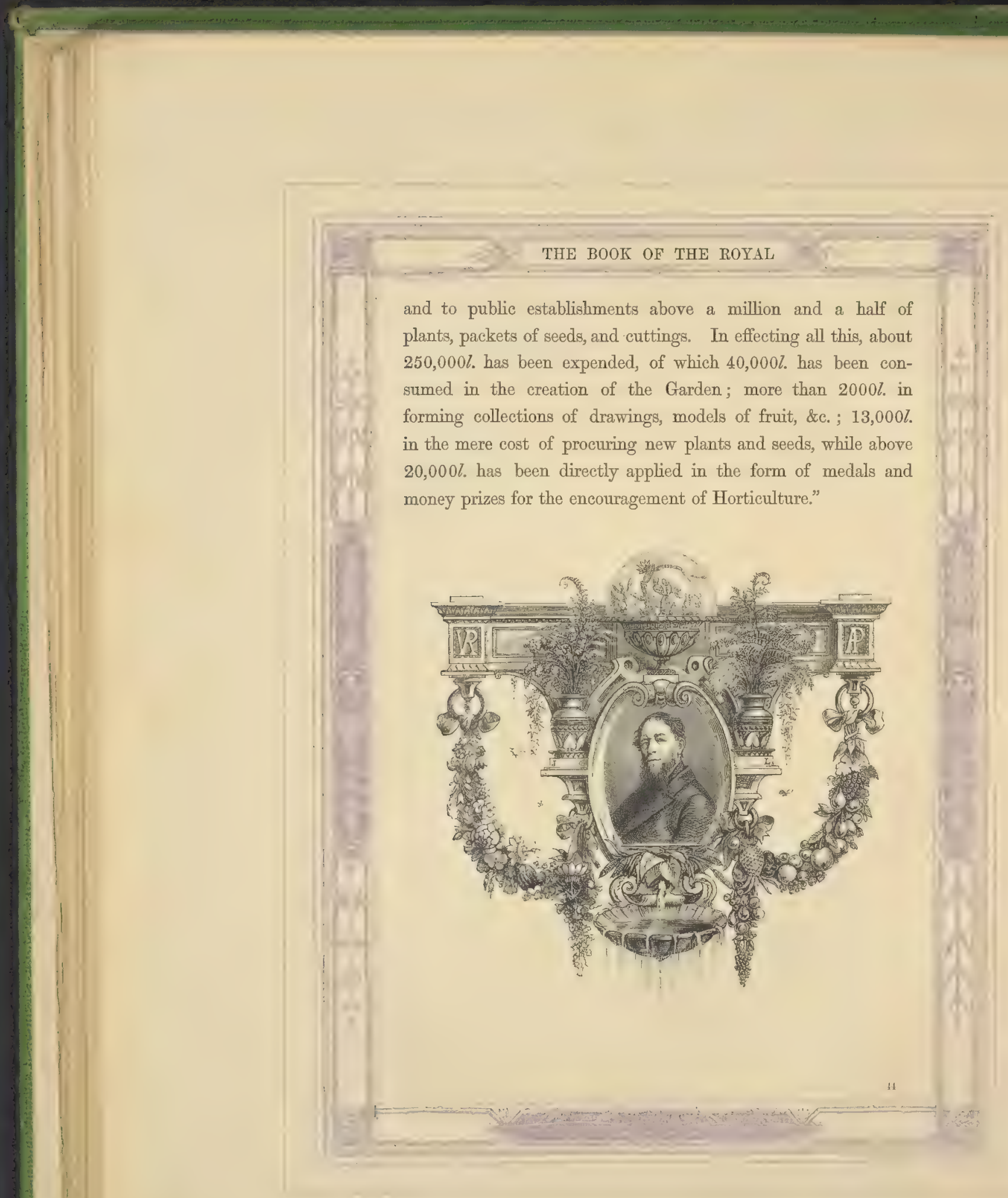


THE PRESIDENCY OF THE PRINCE CONSORT, AND THE MEMORIAL OF 1851. 


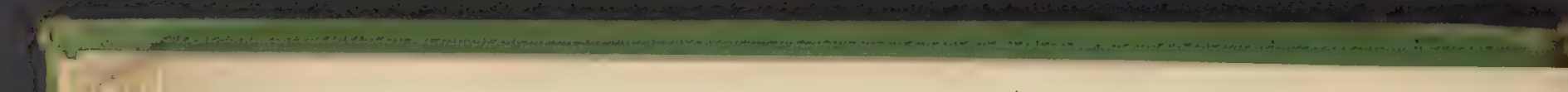




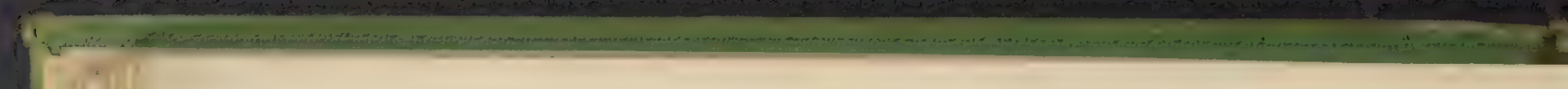





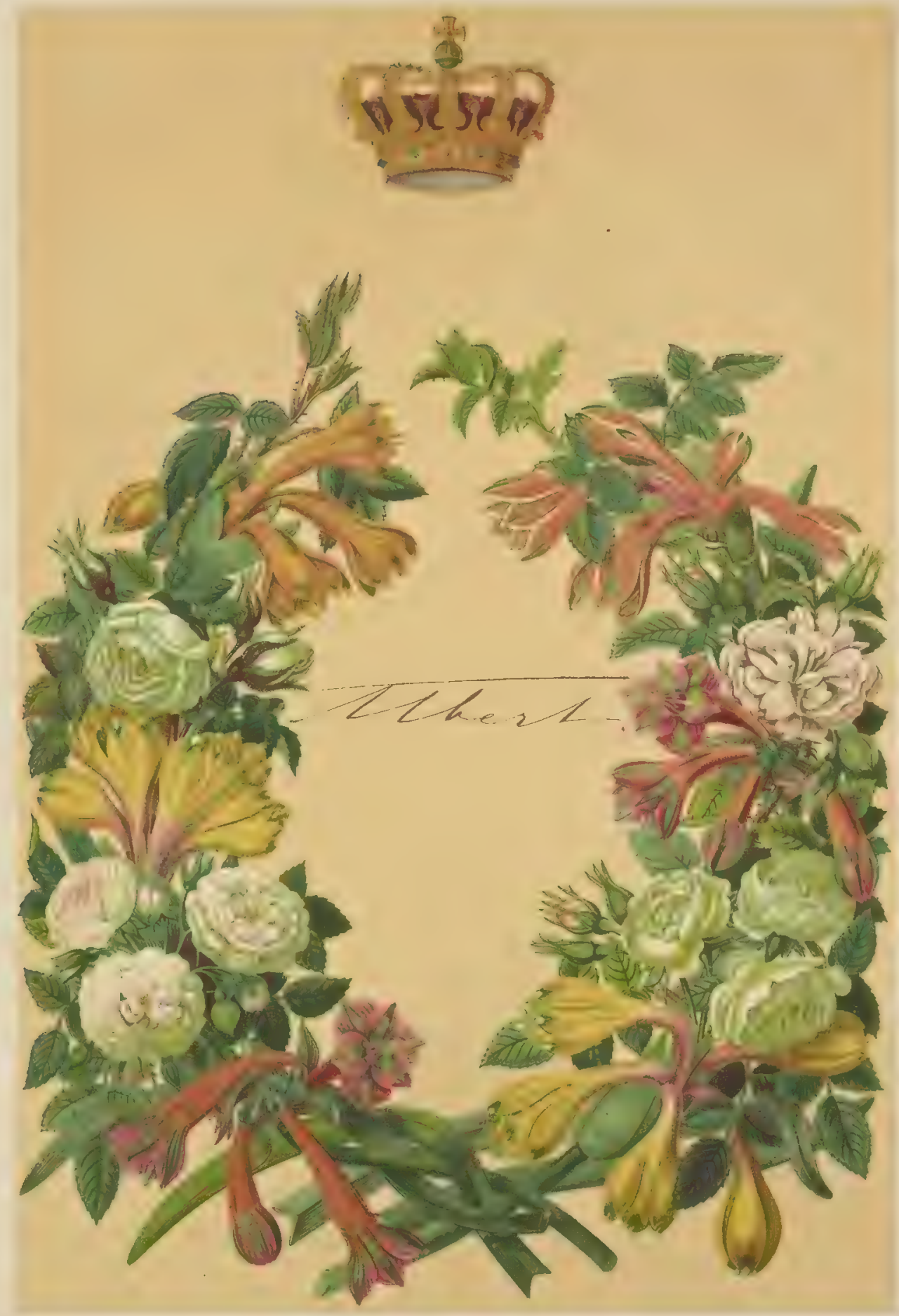

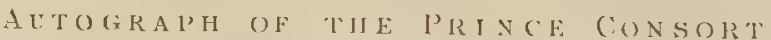




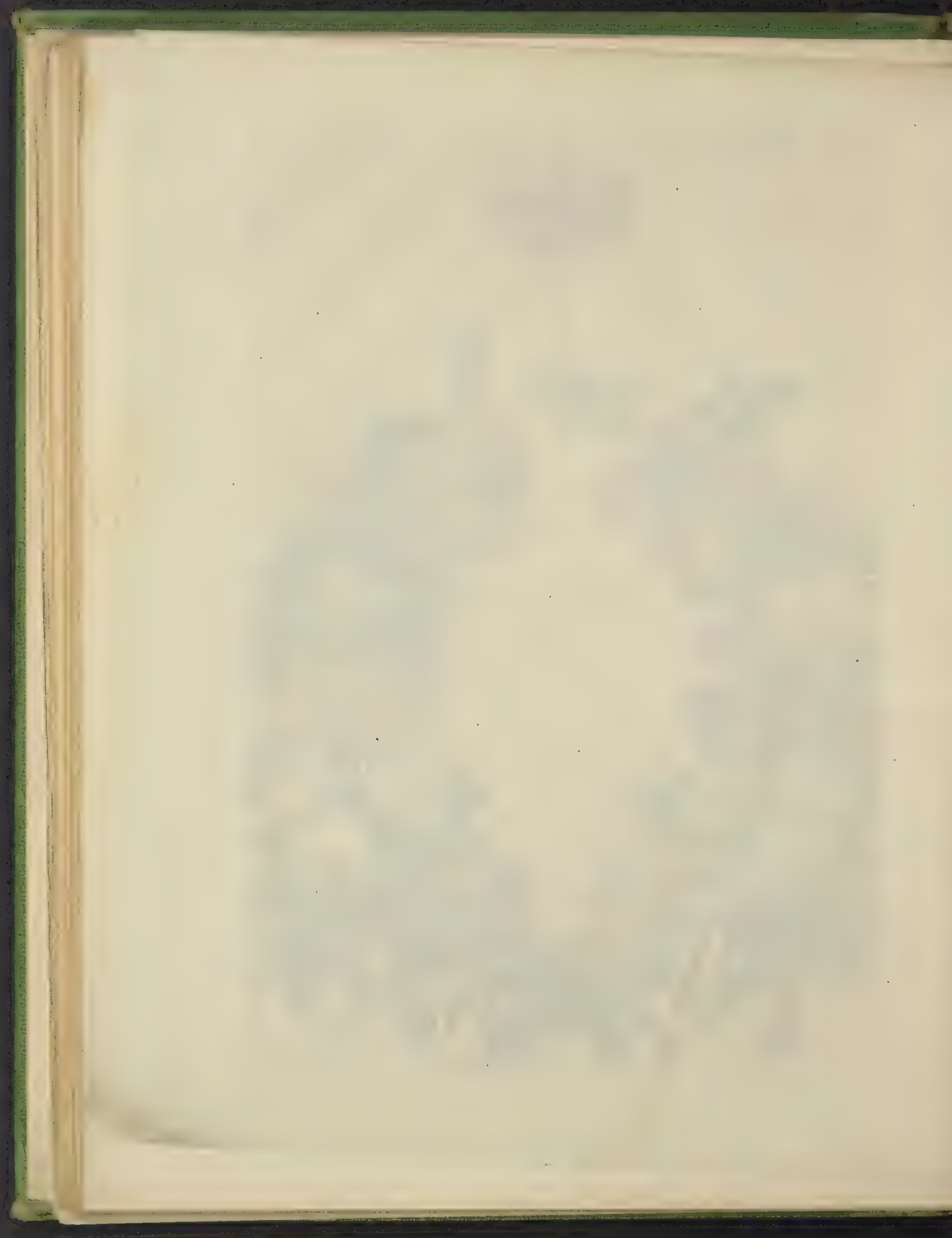




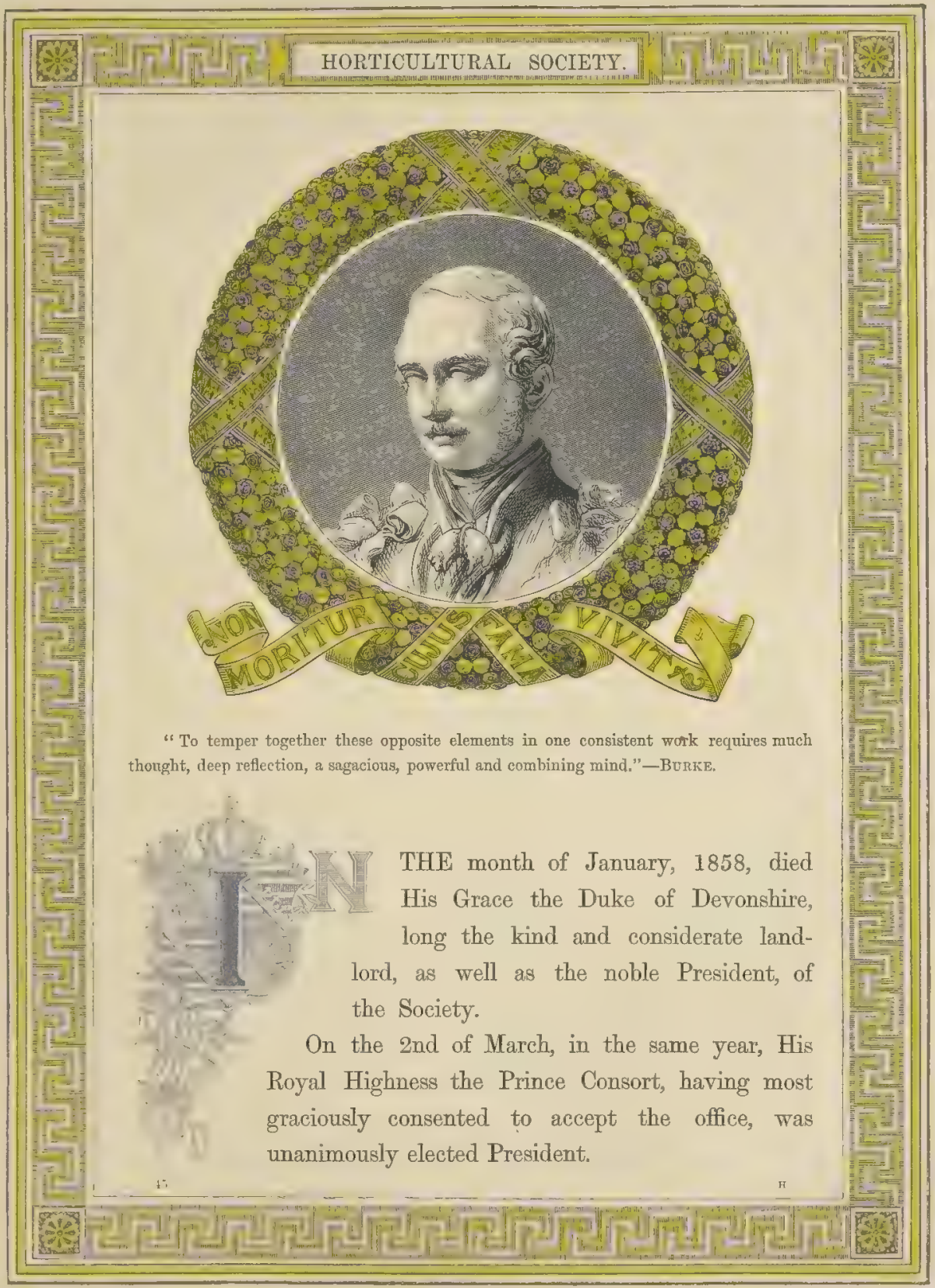




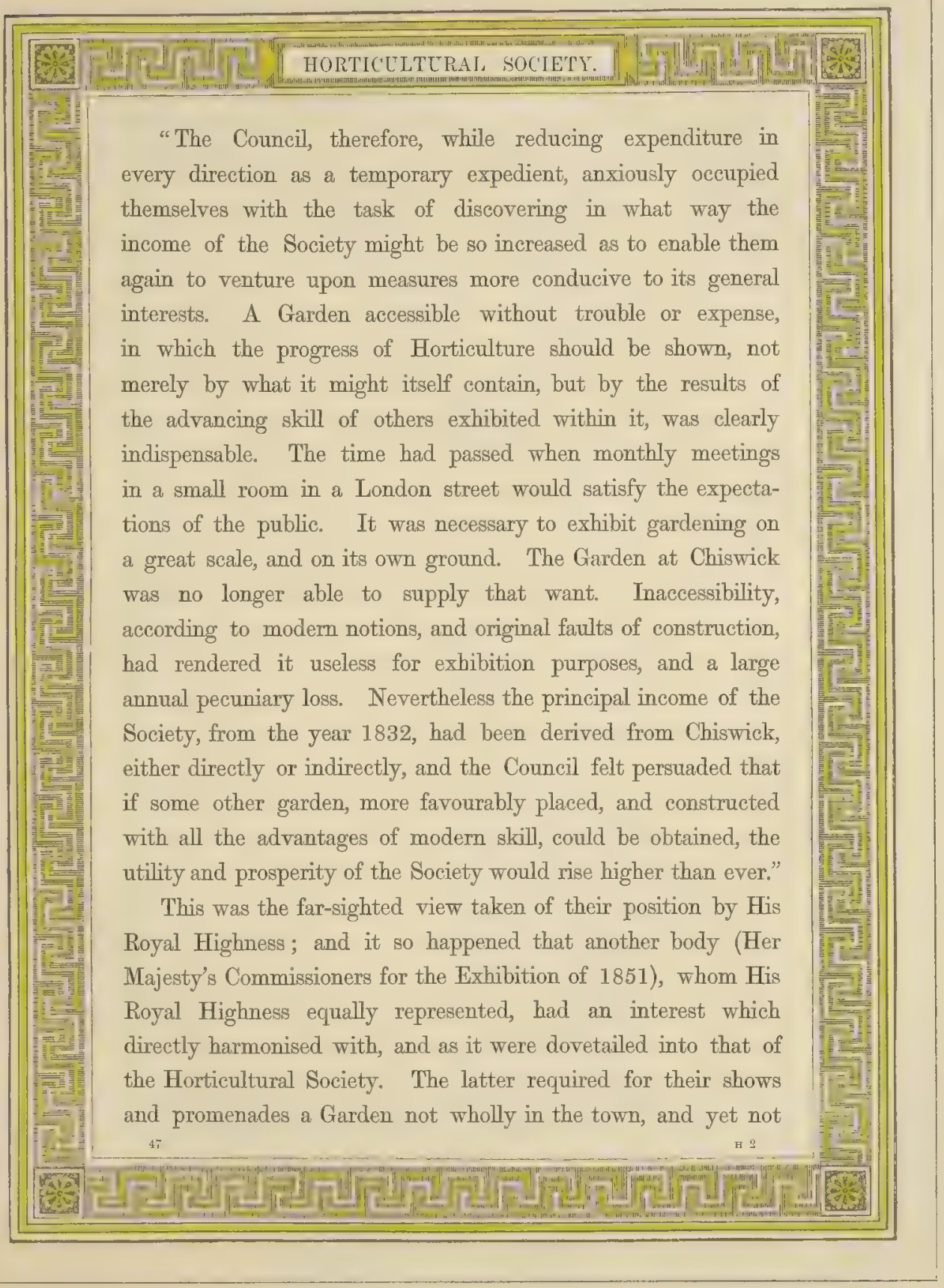


beyond the limits of London; the former, viz., Her Majesty's Commissioners, were actually at the same moment contemplating the appropriation of the central part of their land at South Kensington as a Garden, to be surrounded by Italian arcades, - a purpose the relations of which will be better understood hereafter, when the Prince's noble and statesman-like objects are further developed. His Royal Highness's position, as head of both bodies, rendered the negotiation easy; and at a meeting held at Buckingham Palace on the 27th of June, the Prince announced to the Council that Her Majesty's Commissioners were ready to grant a lease of 20 acres at Kensington Gore upon certain conditions, the more important of which were the following :-

The Commissioners to expend 50,000l. upon a highly decorated Italian Arcade, and certain costly earthworks required as the foundation of a Garden.

The Commissioners to claim no rent until the expenses of the Society-which include interest upon money borrowedshall have been defrayed; all income beyond such expenses to be apportioned in the manner following; that is to say, interest to be paid by the Society on the $50,000 l$. borrowed by the Commissioners, and then, as rent, one moiety of any surplus that may have arisen during each year.

The Society to lay out a sum equal to that of the Commissioners in the formation of the Garden, one feature of which would be a Conservatory of considerable extent.

The Commissioners to grant the Society a lease of the land for 31 years.

The amount of annual expenditure, and the mode of general 


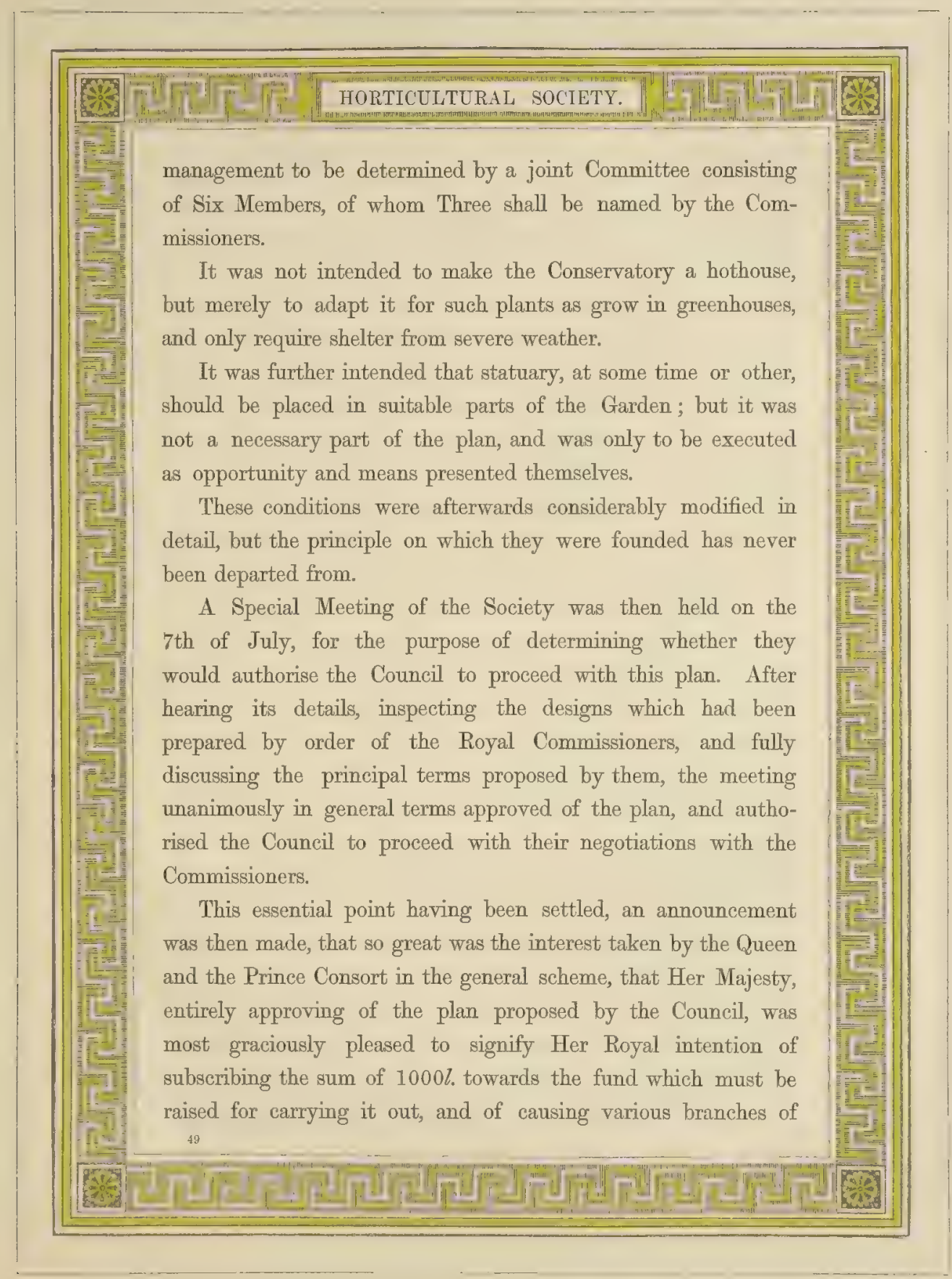


the Royal Family to be elected as Life Members of the Society; at the same time His Royal Highness authorised the meeting to be informed that he also was prepared to subscribe the sum of $500 \%$ in aid of the measure, and to provide a further sum of 1000\%. by taking ten of the debentures of $100 \%$. each, which the Society proposed to issue. It was at the same time announced that Her Royal Highness the Princess Frederick William, Princess Royal of England, proposed to join the Society as a Life Member. These munificent contributions were gratefully acknowledged by every one present, and the noble chairman of the meeting was requested to convey to Her Majesty, to His Royal Highness the Prince Consort, and to Her Royal Highness the Princess Royal, the most respectful thanks of the Society.

As to the mode of raising $50,000 \mathrm{l}$, the Council recommended the issue of debentures bearing interest at 5 per cent., to be redeemed as means should become available. They also proposed to keep up the experimental part of Chiswick Garden, and as much more of that Garden as might be required to furnish decorative plants for the new Garden at South Kensington.

The Council having renewed their correspondence with the Royal Commissioners, for the purpose of obtaining a reconsideration of certain points which, in the opinion of the meeting, demanded some alteration, a second General Meeting was held on the 20 th of July. The Council then explained what progress had been made in the negotiations. The Commissioners had agreed to add to the arrangements with the Society stipulations to the following effect:- Upon the Society giving two years? 
notice previous to the expiration of the lease, it was to be renewed for a further period of 31 years upon the same conditions as to rent, \&c., as those already proposed. The Commissioners were, however, to reserve to themselves a power to decline to renew the lease, in which case they were to be bound to take upon themselves the responsibility of any Debentures that might be outstanding at the expiration of 31 years, to any extent not exceeding a maximum of $20,000 l$. But the Commissioners required the Society to devote in each year not less than 50 per cent. of their surplus balance to paying off outstanding Debentures. And in the event of the Society being unable for any five consecutive years to pay interest on the $50,000 \%$ to be borrowed by the Commissioners, then the Commissioners were to have the right of re-entry without any payment of compensation.

On this occasion the two following resolutions closed the deliberations of the Society:-

"That this meeting approves of the steps already taken by the Couneil, authorises the negotiations with the Royal Commissioners to be continued, and empowers the Council to proceed to raise the sum required for the construction of a Garden at Kensington Gore, and if the money shall be obtained, to complete the arrangements."

"That the Council be instructed not to accept the clanse about re-entry in case of failing to pay interest for five years, and that in the event of the Commissioners cancelling the lease, an equitable adjustment of mutual interests be made."

Further negotiations terminated in an agreement being come to by both parties, embodying the chief points above noticed. The clause objected to was modified to the effect that in the event of the Commissioners cancelling the lease after five years' non-payment of rent, an equitable adjustment of mutual interests 52 
should be made. A copy of the deed of agreement will be found in the Appendix.

The funds required were raised with the greatest ease; the donations amounted to 1867l. 12s. Six hundred new Fellows immediately joined, and, altogether, within twelve months, 13,000l. was obtained from Life Memberships. The Council had merely to intimate their desire to borrow $40,000 \%$. on $100 l$. debentures, bearing 5 per cent. interest, and conferring the privilege of one admission to the Gardens, when the whole of the debentures were immediately taken up.

So soon as it had been ascertained that the requisite funds could be provided, the assistance of Capt. Francis Fowke, R.E., Mr. W. A. Nesfield, and Mr. Sydney Smirke, R.A., three gentlemen, each of the highest talent in his own department (engineering, landscape gardening, and architecture), was secured to assist in designing and constructing the garden. Many meetings of the Council and of the Commission, at which His Royal Highness presided, were held with these gentlemen, and the plans which have been since carried out were gradually arrived at; not, however, without many trials, many variations, and many alterations; for it is one of the peculiarities of all the works of embellishment in the Garden, that nothing has been finally executed until, by previous modelling (often of the size of nature) and altering and amending, a satisfactory result was arrived at. Were such precautions more generally adopted, many an expensive blot, which now disfigures our public buildings, would have been saved by the timely expenditure of a few pounds.

The actual execution of the greatest part of the work was 59 


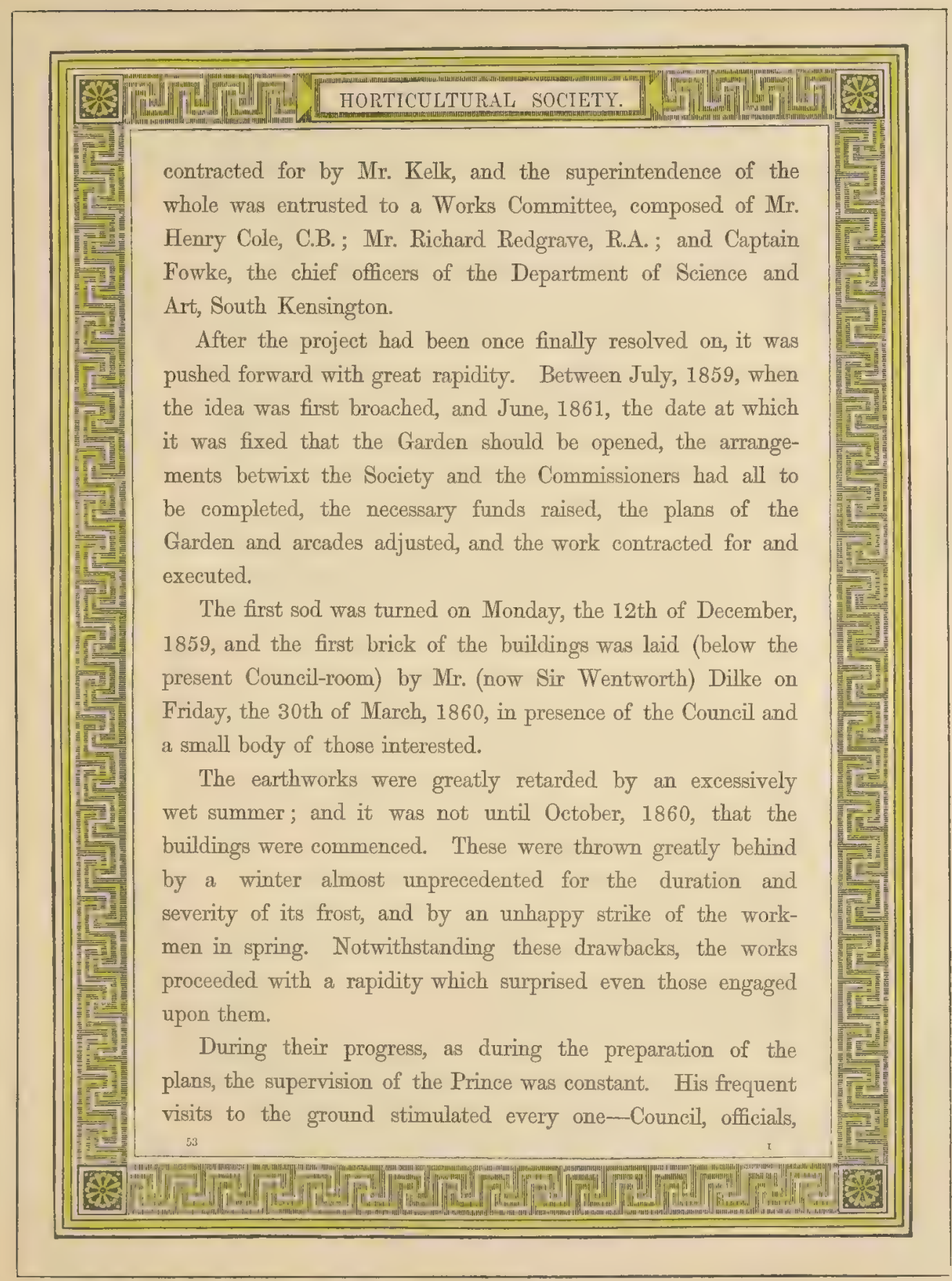




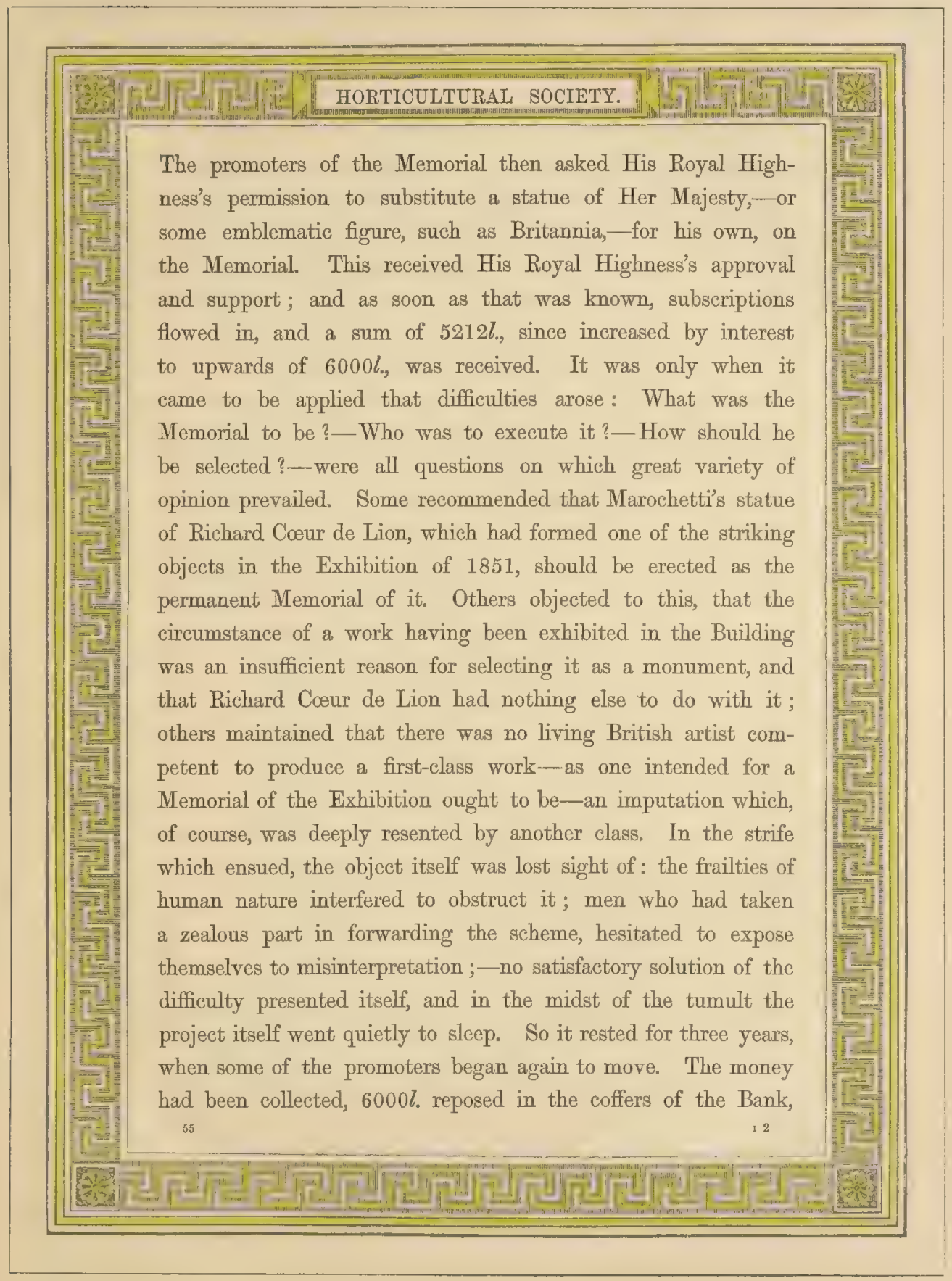




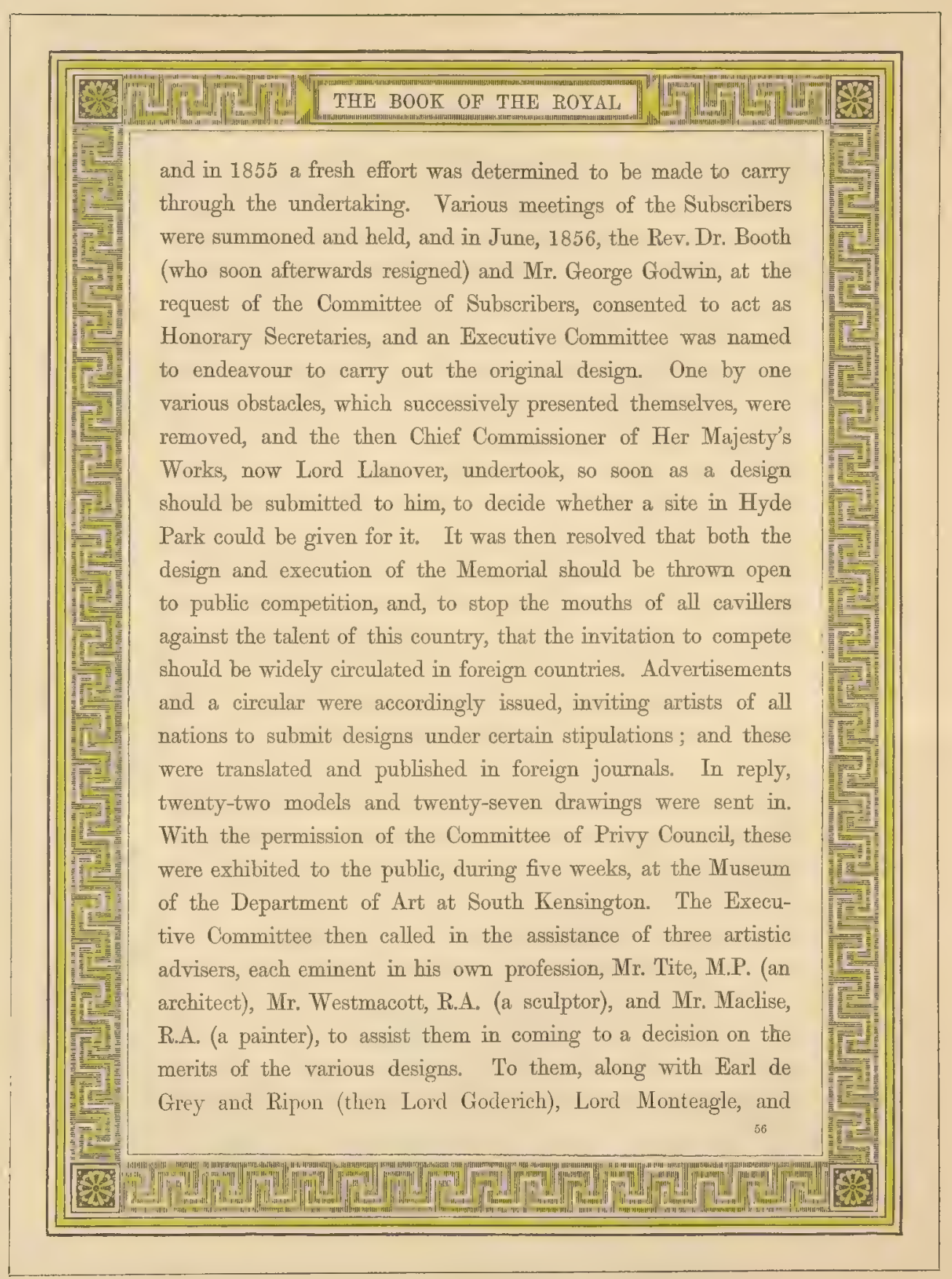




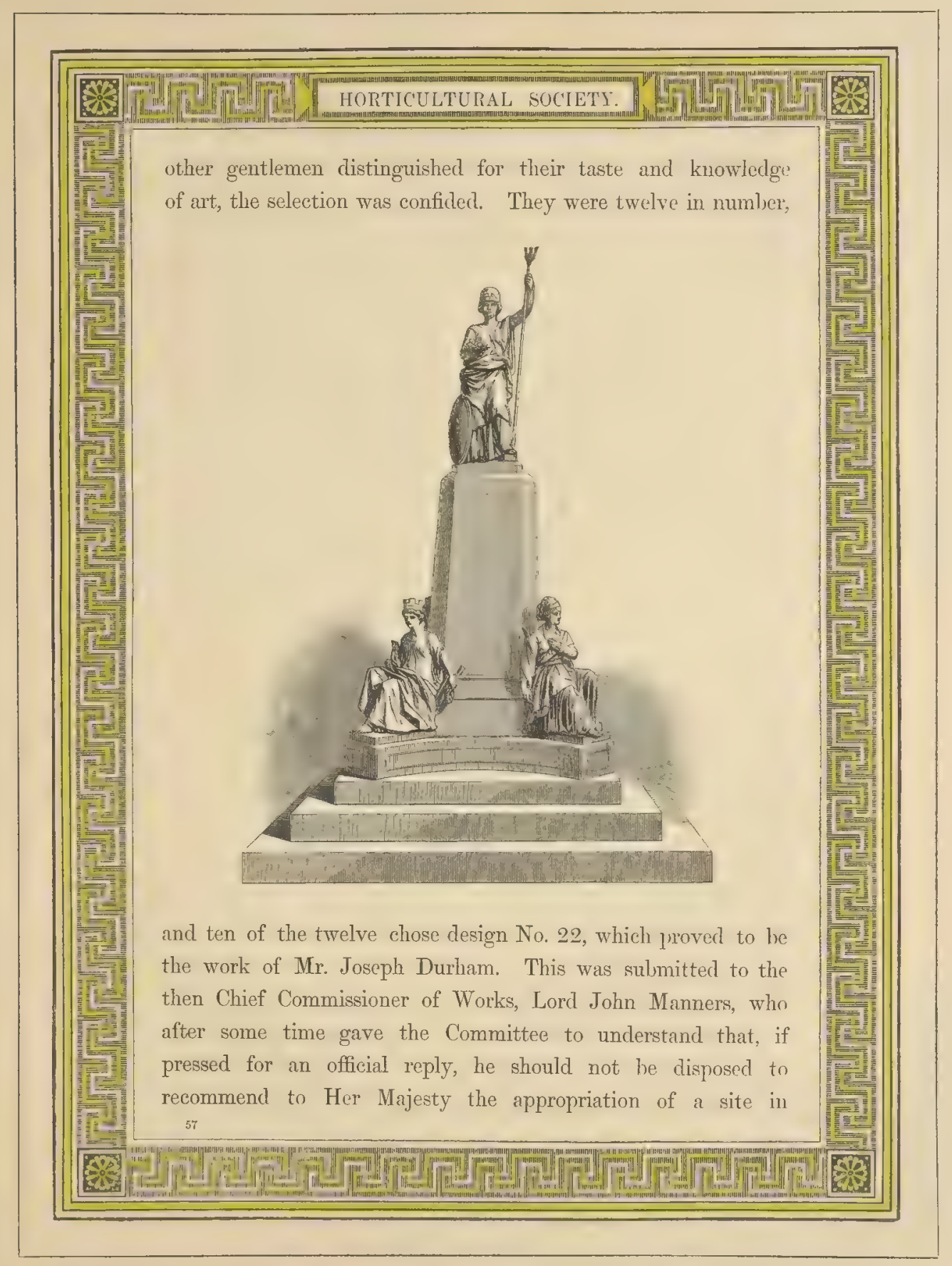




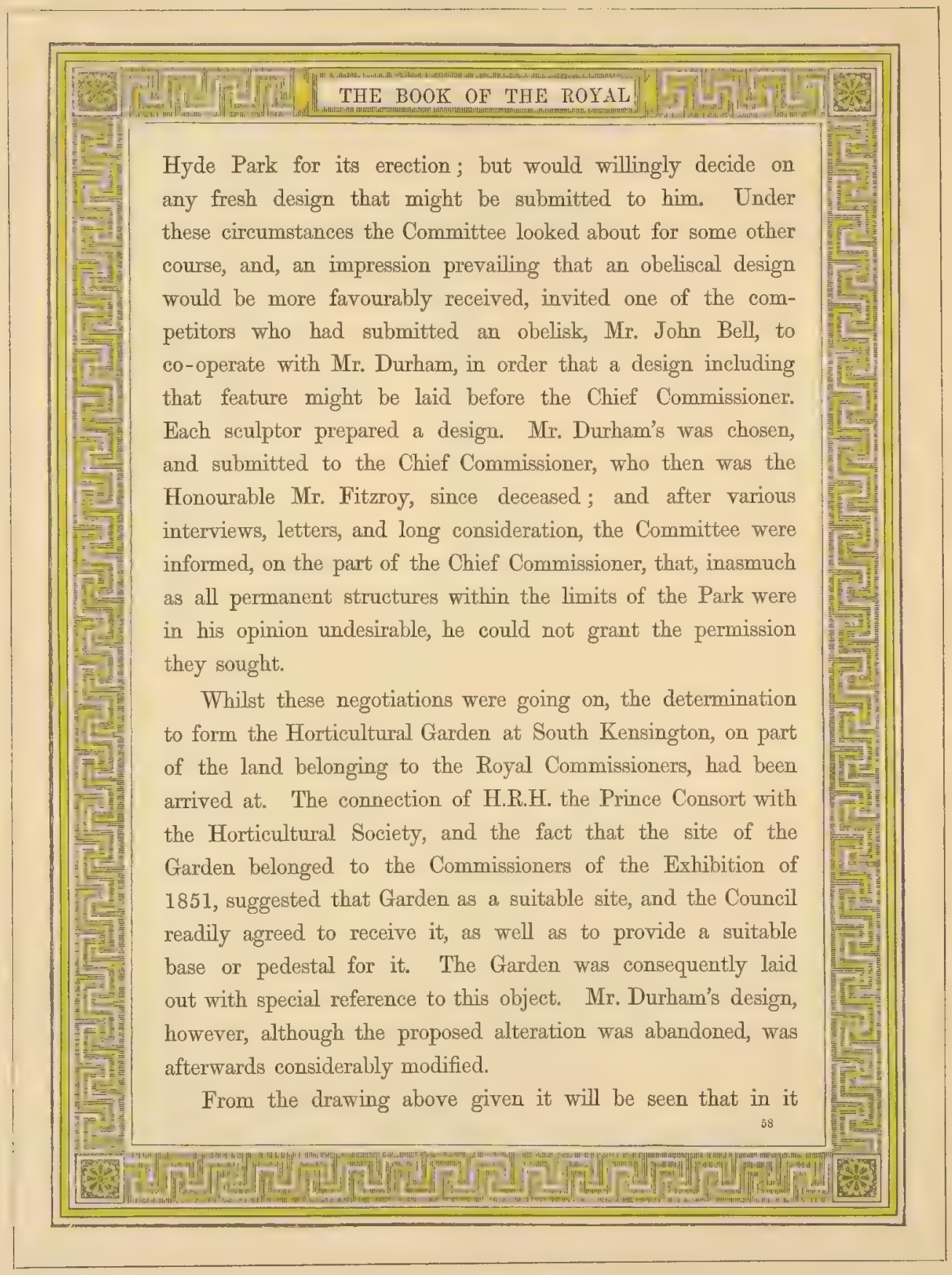




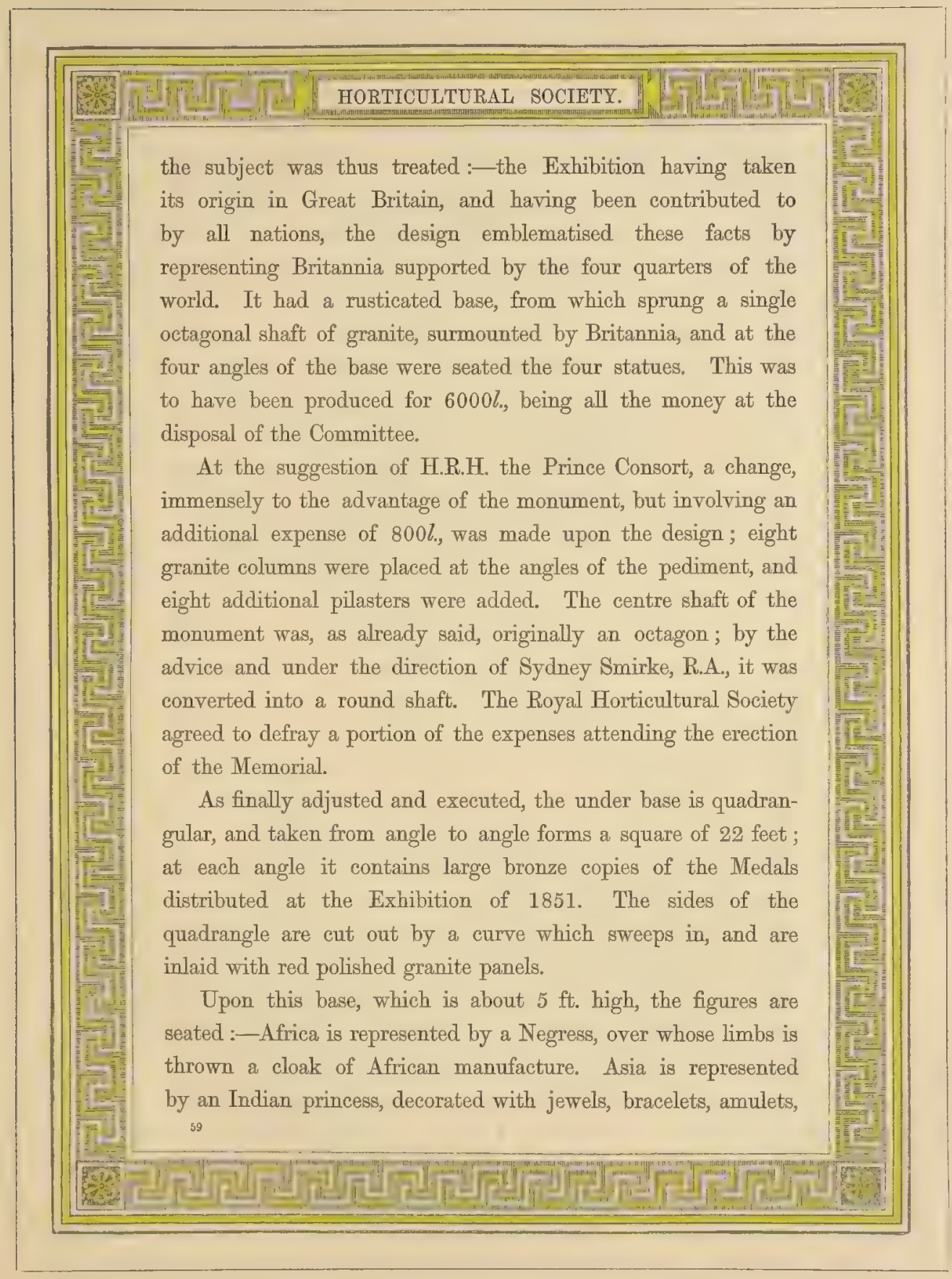




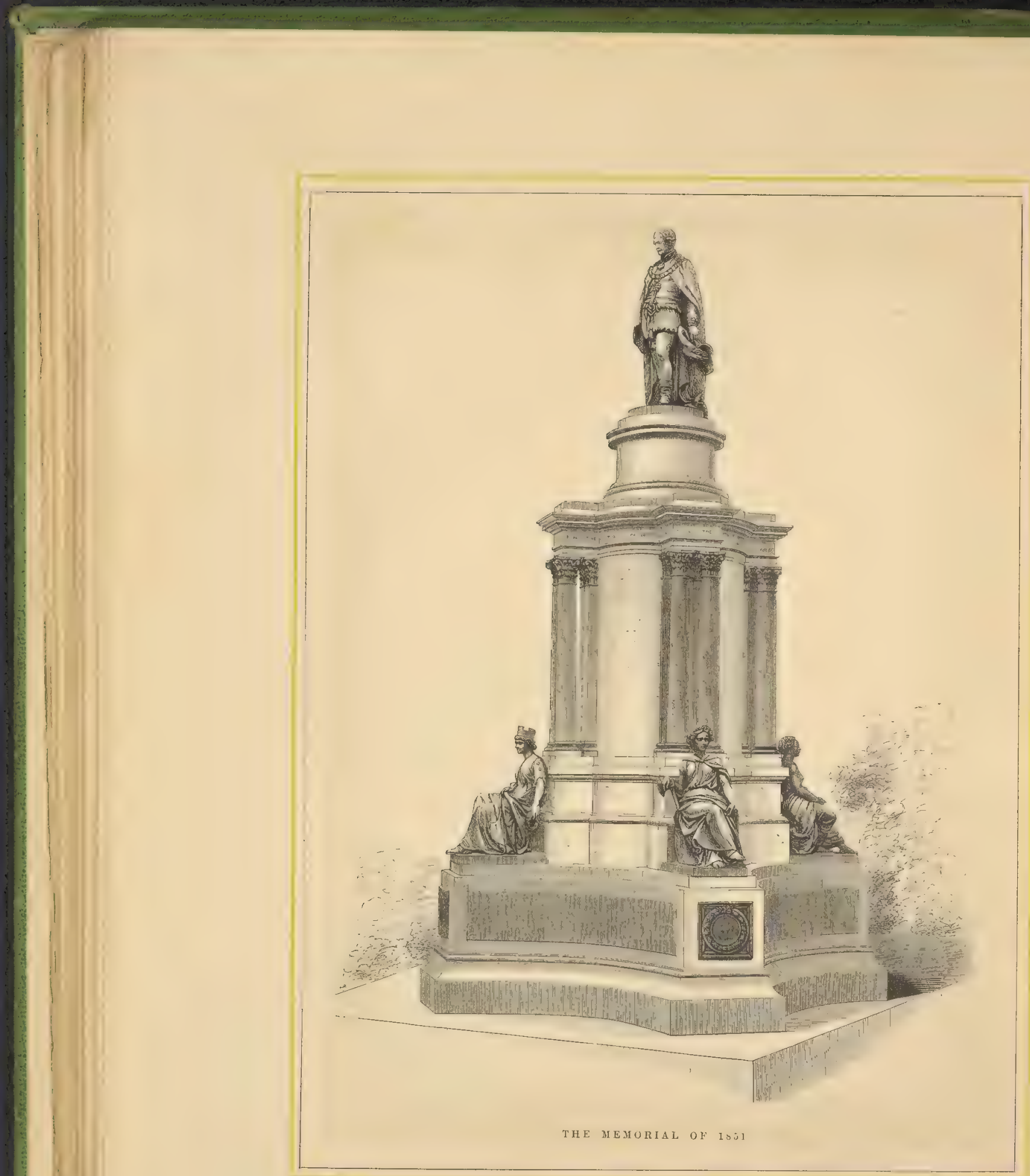




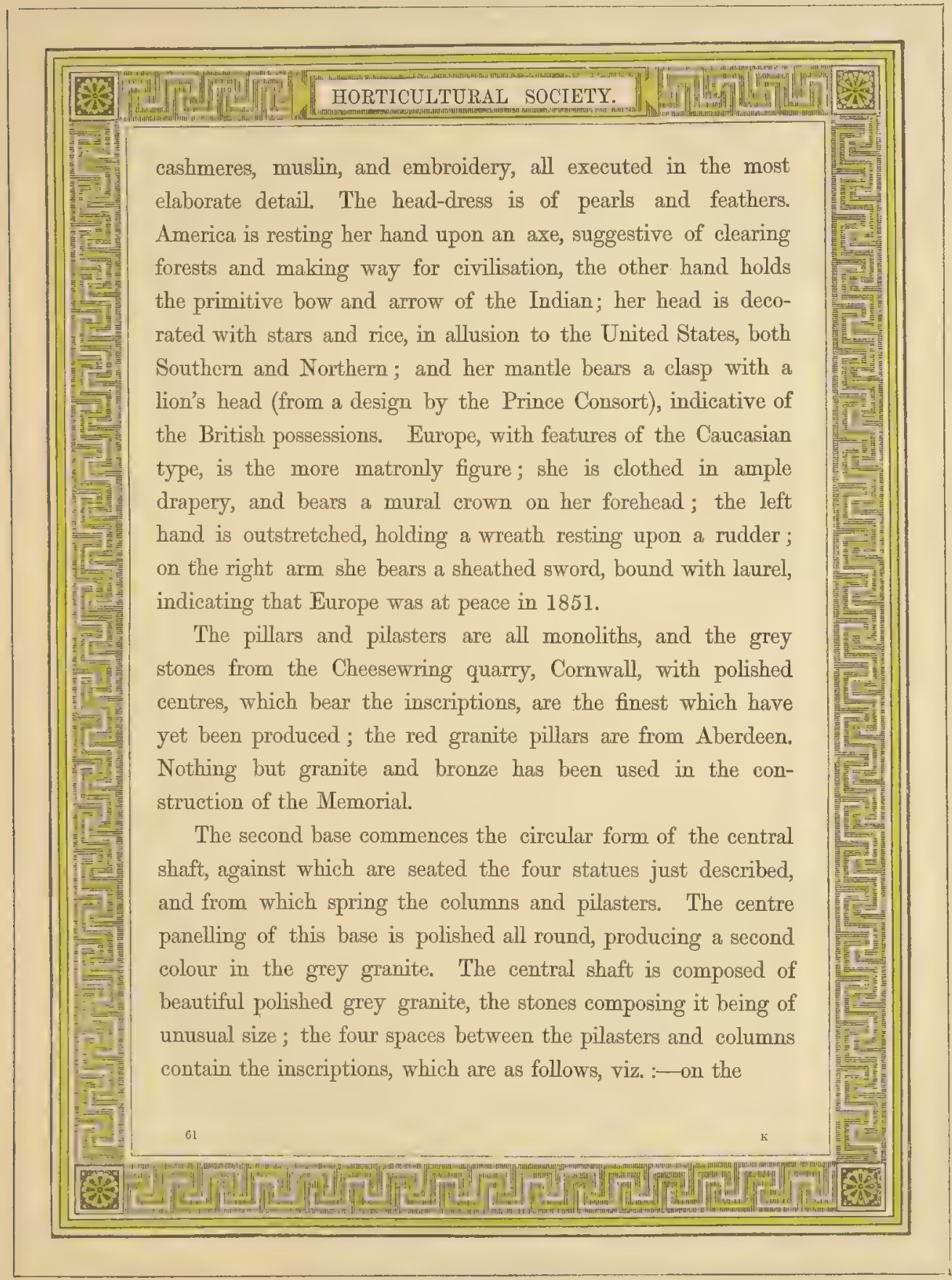




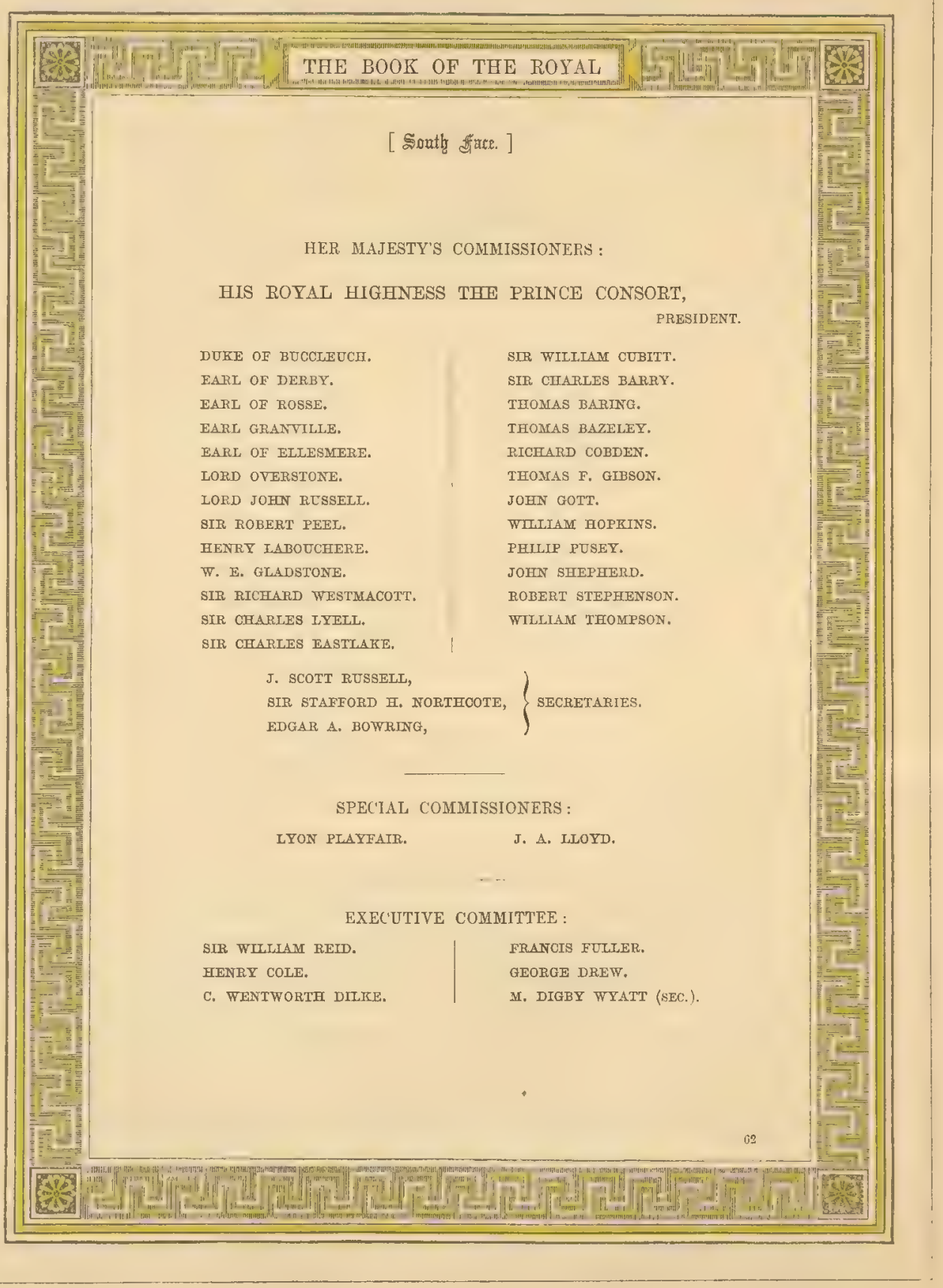




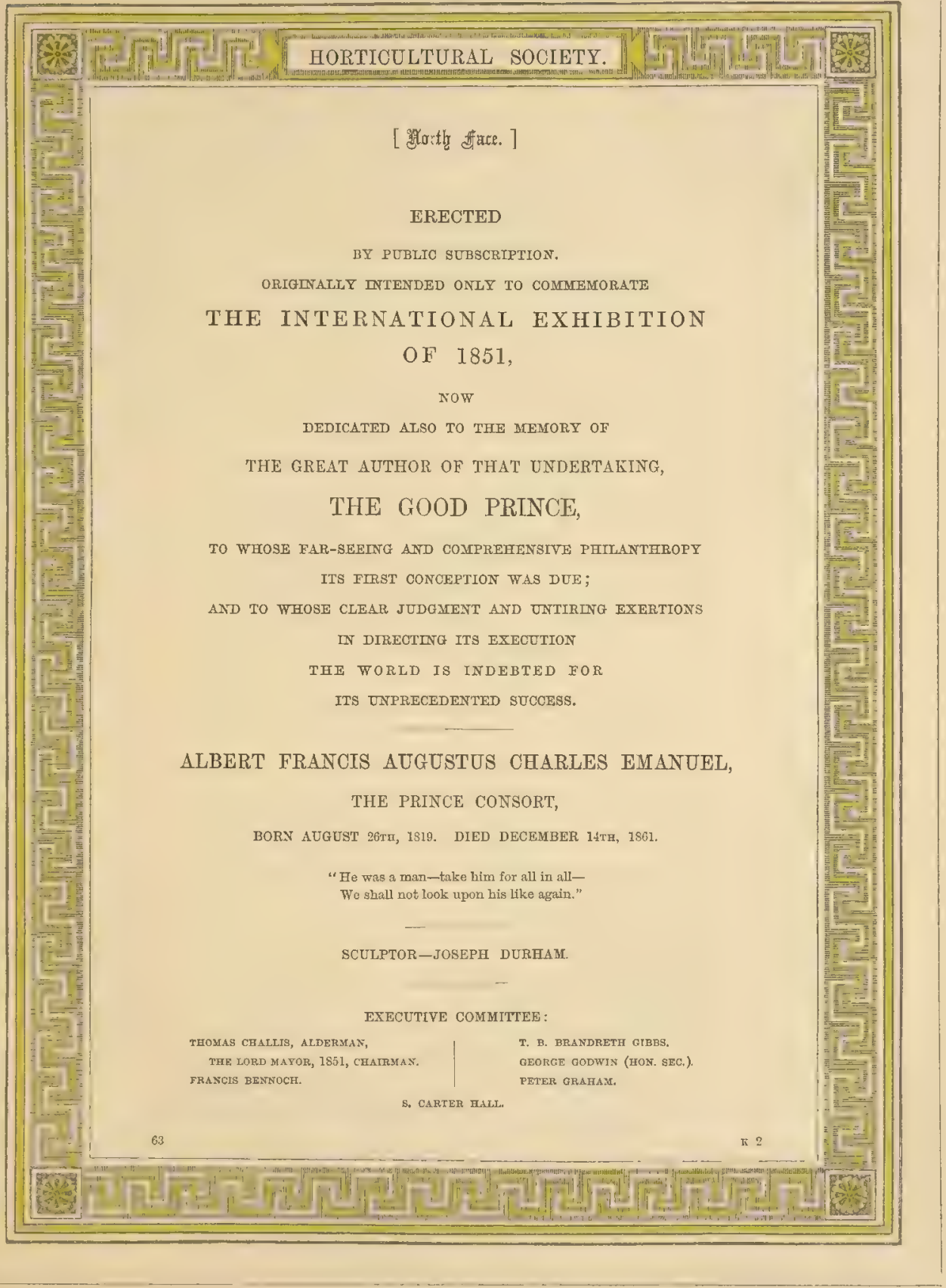




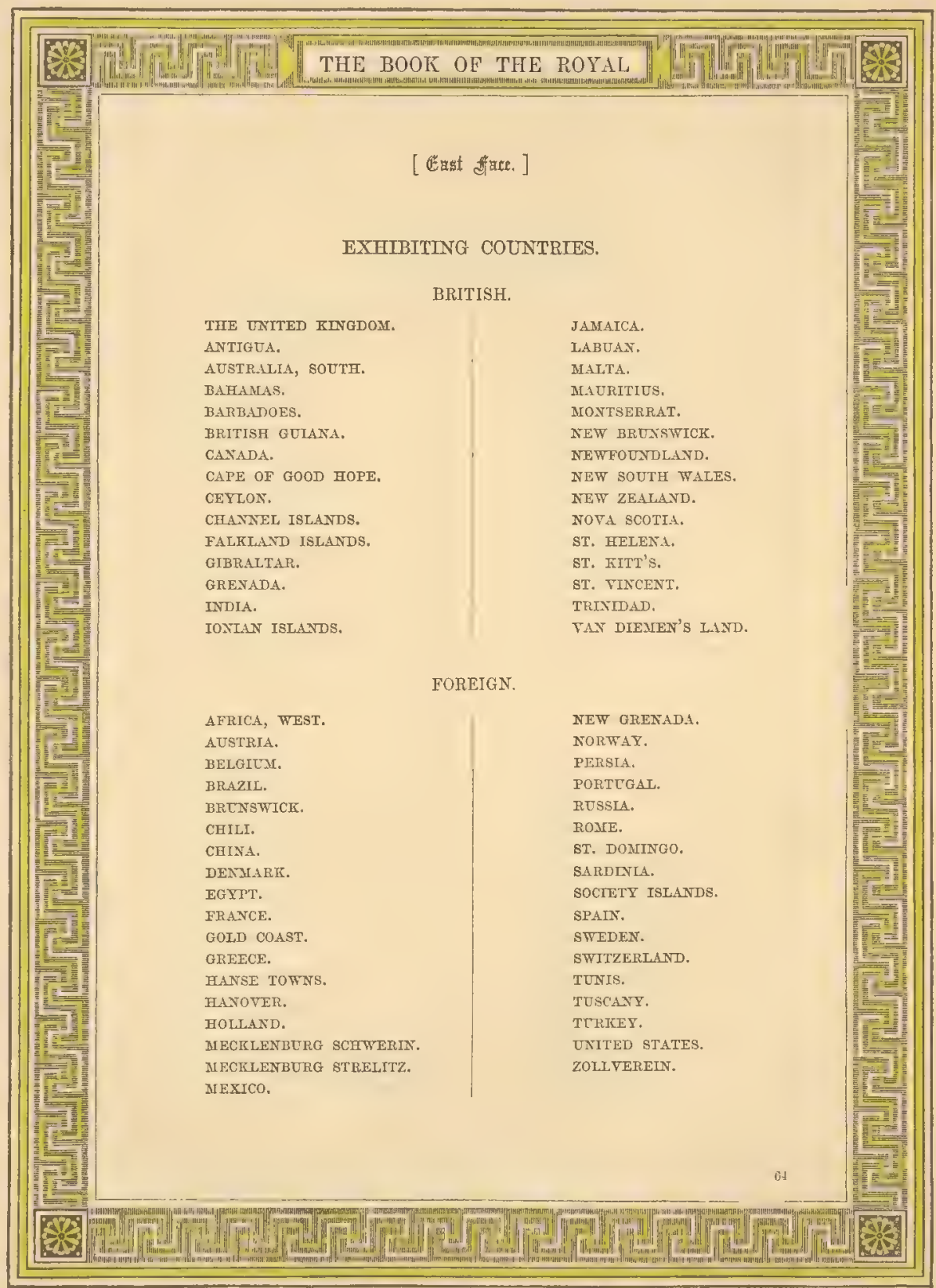




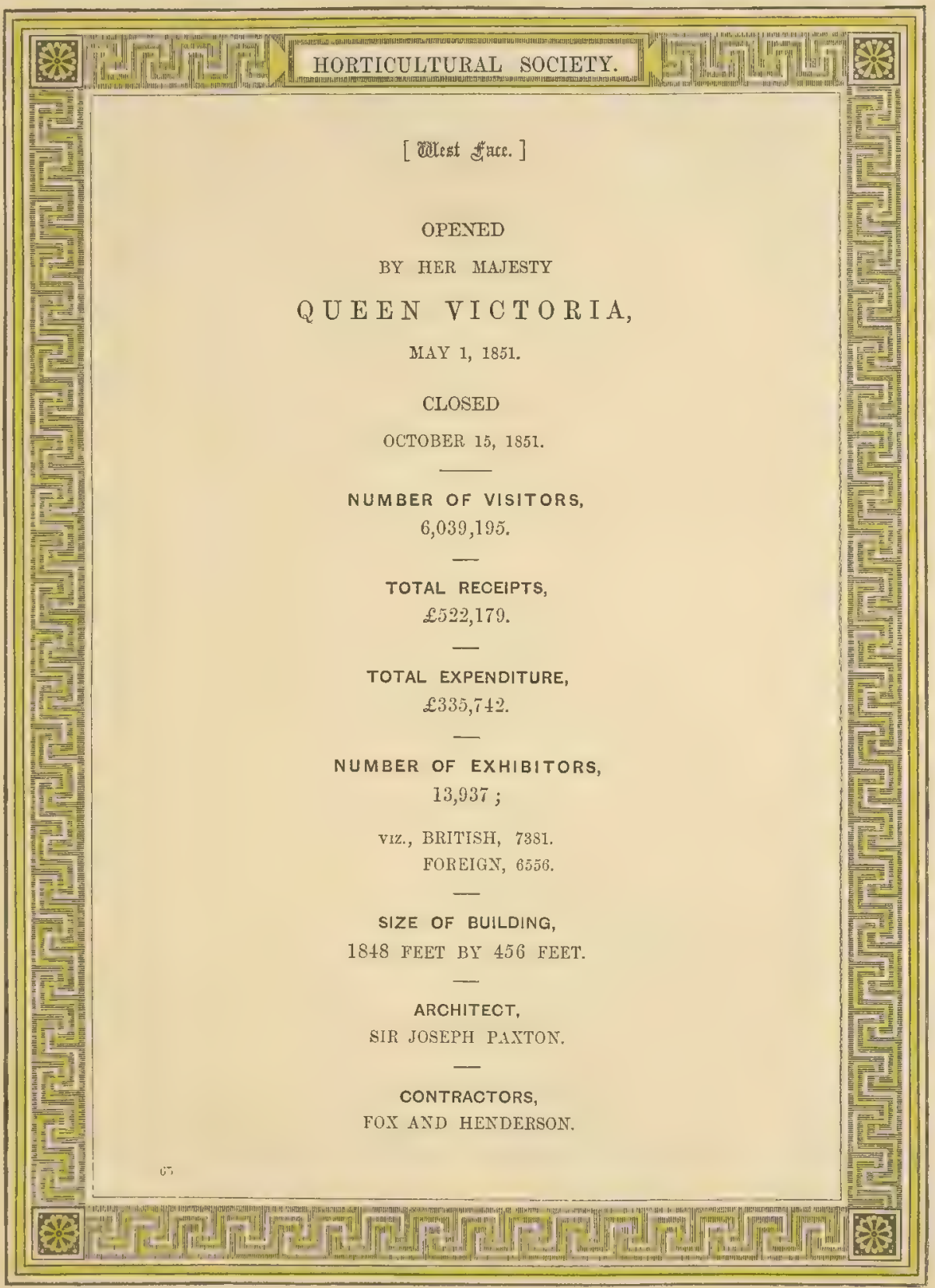


Bronze capitals, approaching the Corinthian order, designed by Sydney Smirke, R.A., surmount the pillars and pilasters. The columns support a frieze bearing (in letters five inches high) the following inscriptions, upon a third line of polished granite : -

"Let all the nations of the Earth be gathered together, and let the people be assembled."-IsaIah xliii. 9 .

"I will remember the works of the Lord, surely I will remember the wonders of old."-Psarm lxxvii. 2.

Upon this rests a red polished granite pedestal to support the figure on the top. In the original design, the statue, as already mentioned, was to be an emblematic figure of Britannia; by desire of the Committee this was altered into a figure of Her Majesty. Mr. Durham accordingly executed a statue of Her Majesty. The model was tried on a scaffolding erected for the purpose, of the proper height, and received the approval of H.R.H. the Prince Consort. To see this statue was one of the last visits the Prince paid to the Gardens, or the metropolis. Whilst being executed in bronze, the lamentable death of H.R.H. changed the position of matters. The objection which had been taken by himself to his own statue being placed on the Memorial no longer existed. Her Majesty and H.R.H. the Prince of Wales were the first to feel that the statue of the Prince Consort ought to be the one to fill that place, and under this feeling, the Prince of Wales at once proposed that this should be done, in the affecting letter from him to the Council and the Memorial Committee, afterwards quoted. The proposed change was at once agreed to. Mr. Durham was employed to model the statue. Beyond his own personal 


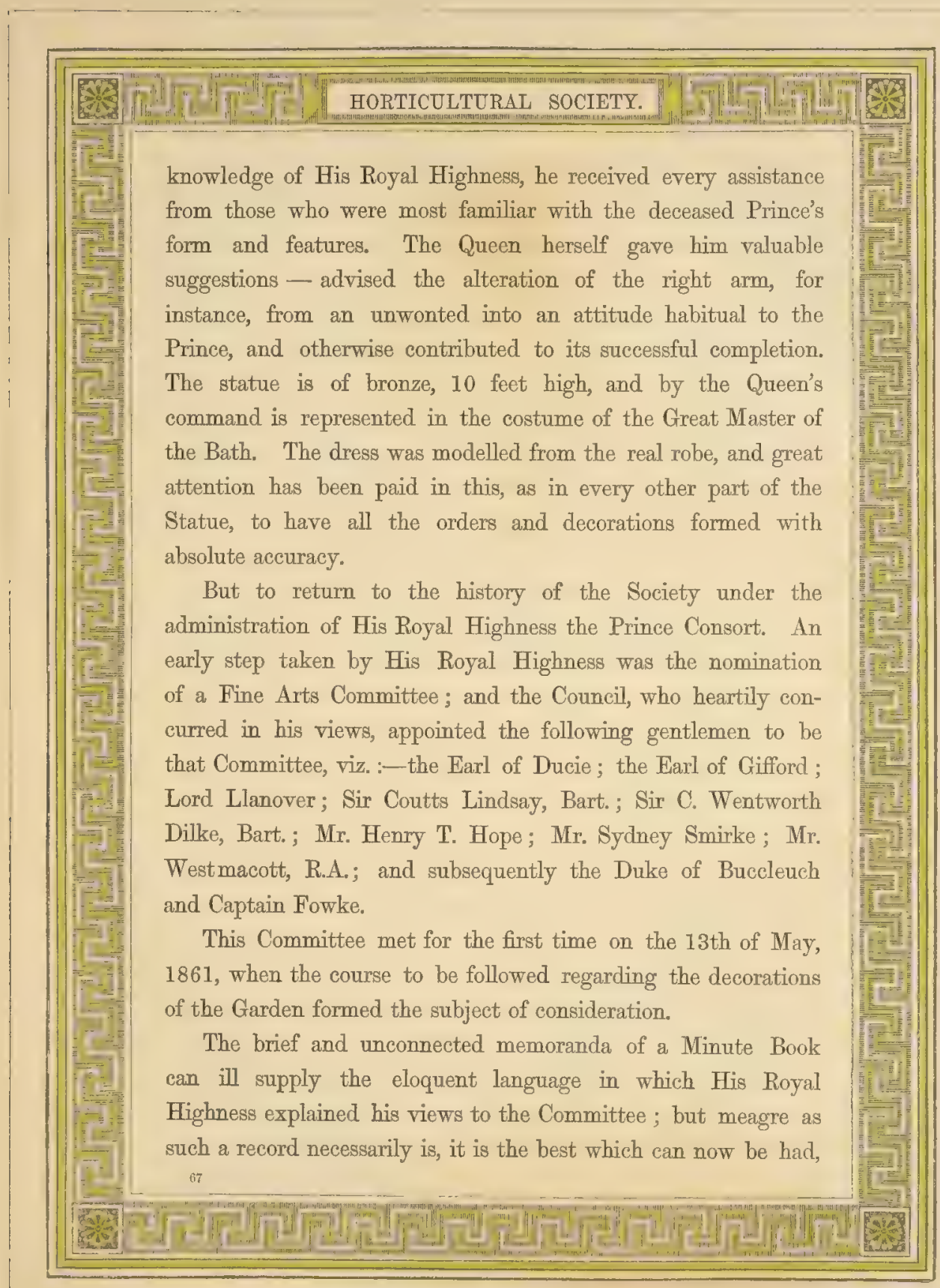




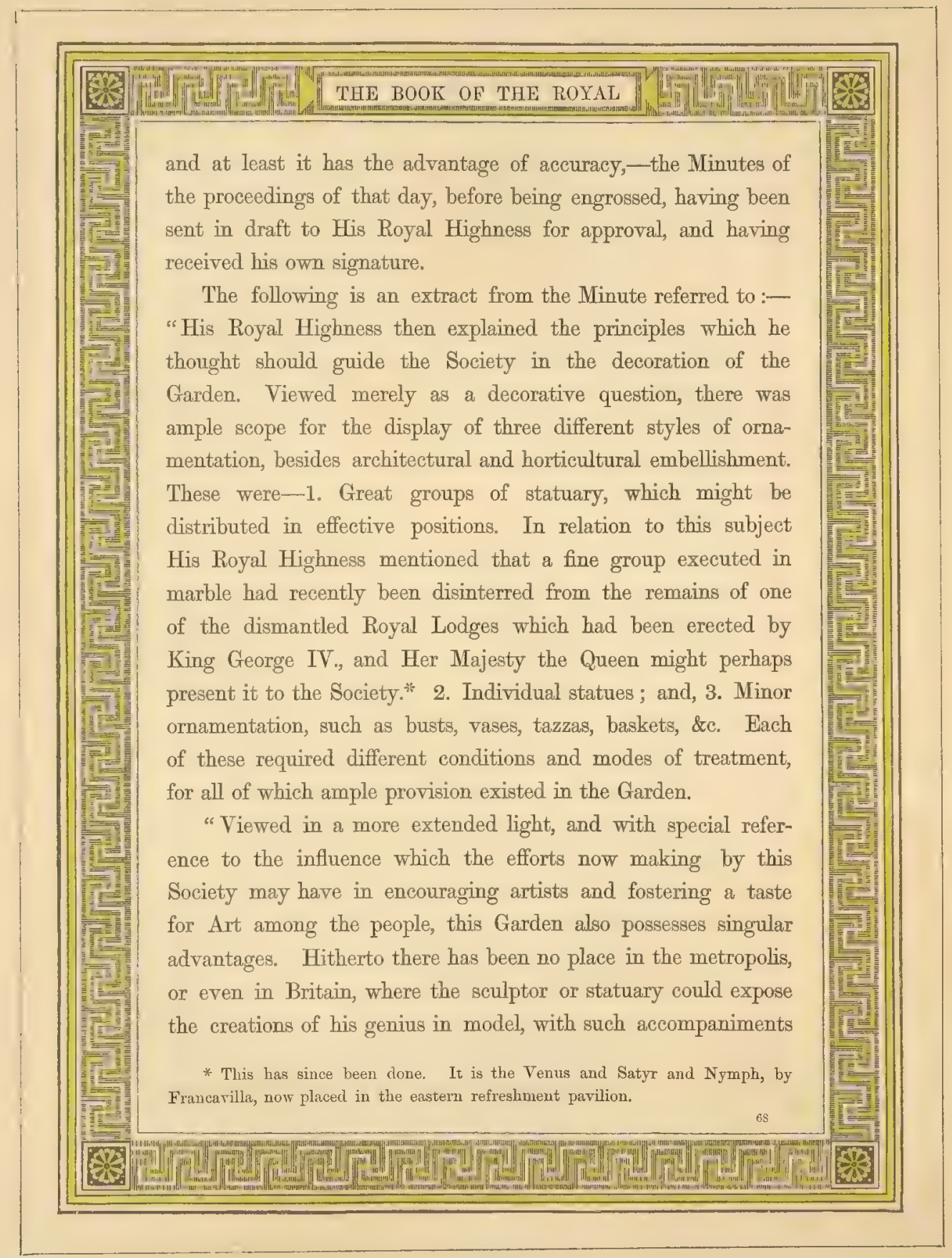


of place and scenery as would give them fair play. Huddled in confined studios, no just conception could be formed of the effect which the larger models would have when placed in the conditions for which they were intended. Were such a place as this garden open to artists for the exhibition of their models, they could be seen under such conditions as would enable their faults to be detected and remedied; their applicability for their intended positions ascertained; their beauties to be seen and appreciated; and the encouragement of the Fellows and the public better secured. These advantages would of themselves be a sufficient inducement to the artist not only to send the models which are already lumbering his studio but also to execute others, and would thus give an impetus to this branch of art of which the want of such opportunity of exhibition has hitherto retarded the development in this country.

"The recent discoveries and improvements in the material in which such ornamentation may be executed is another element which must largely foster its advancement. Terracotta, .cast-iron, plaster, cement are all materials which may now be used with success, yet which a few years ago would have been condemned as utterly unfit for the purpose. The mode in which these facilities for exhibition should be given to artists and their co-operation secured, would be for the consideration of this Committee. An undertaking by the Society to expend a considerable sum in the purchase of the best objects exhibited might be one mode of attracting superior talent; other modes would suggest themselves, and many, both artists and manufacturers, would no doubt be very glad to embrace the opportunity afforded them, with no other 60

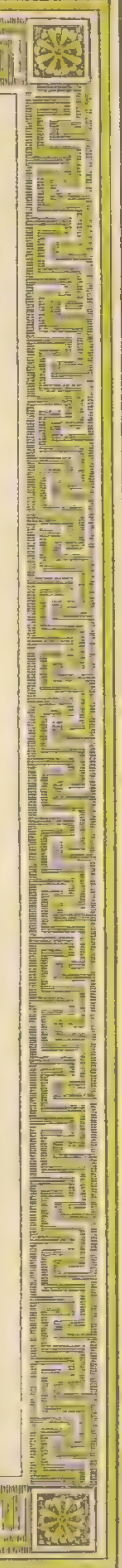




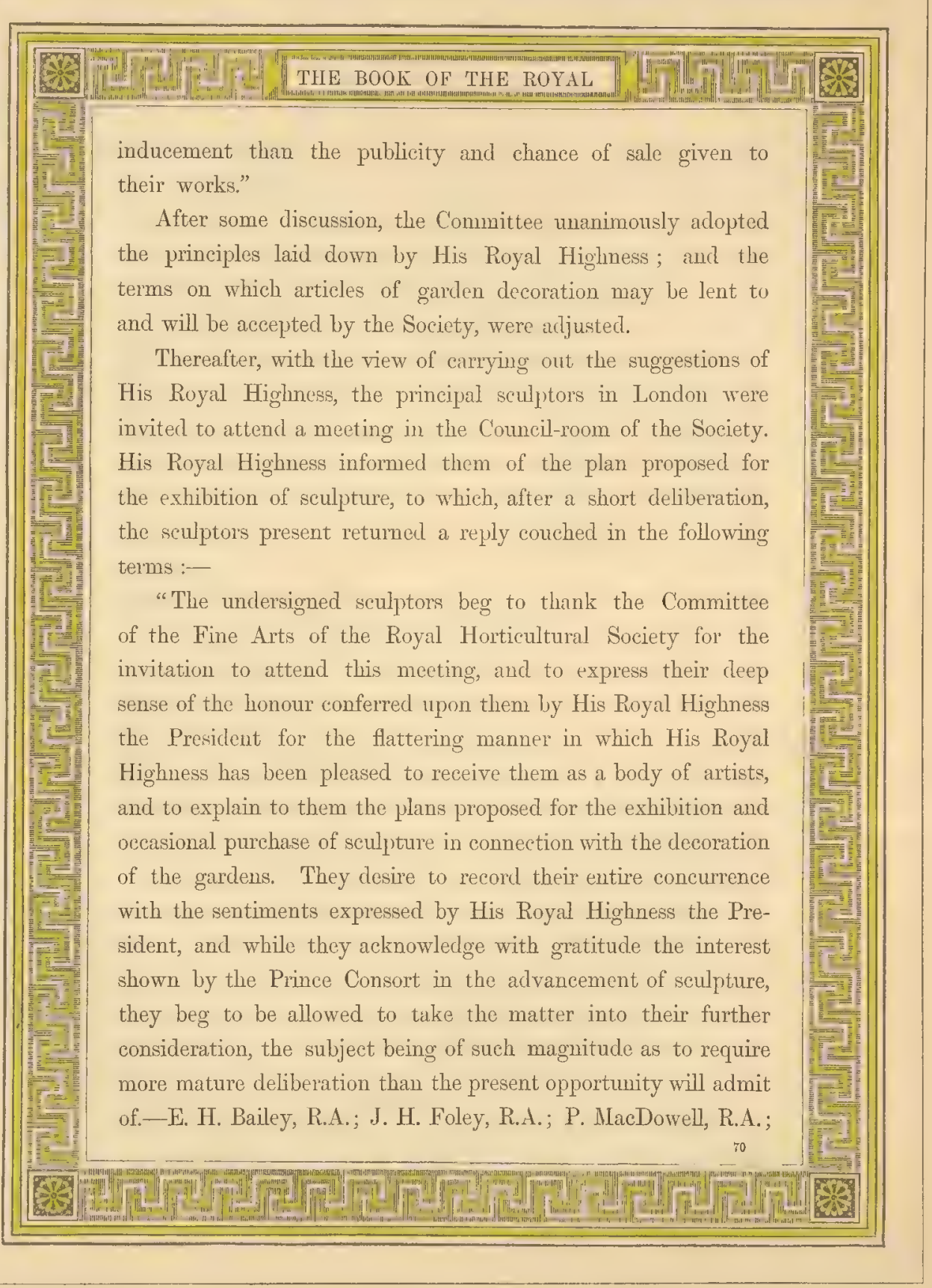




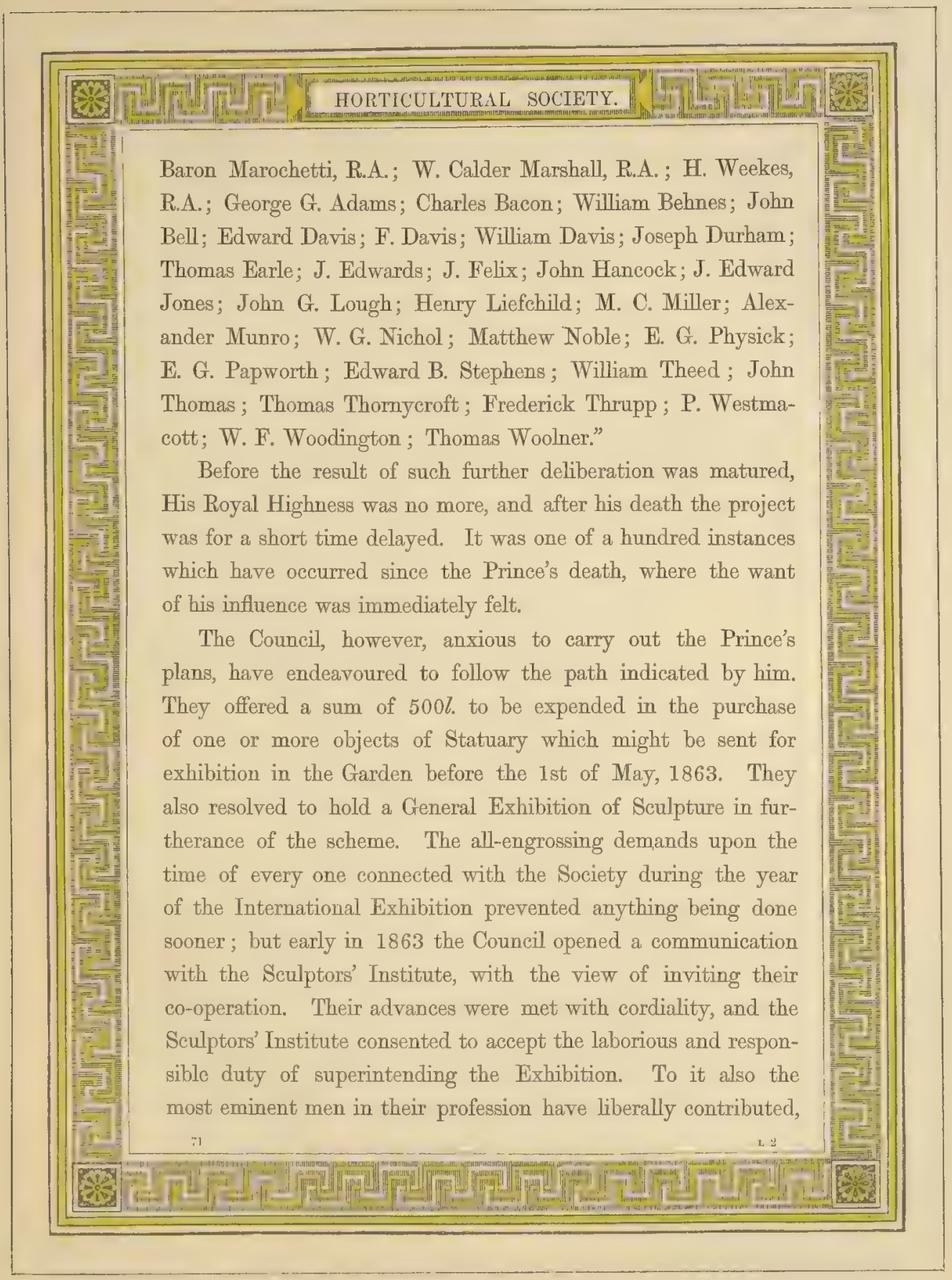




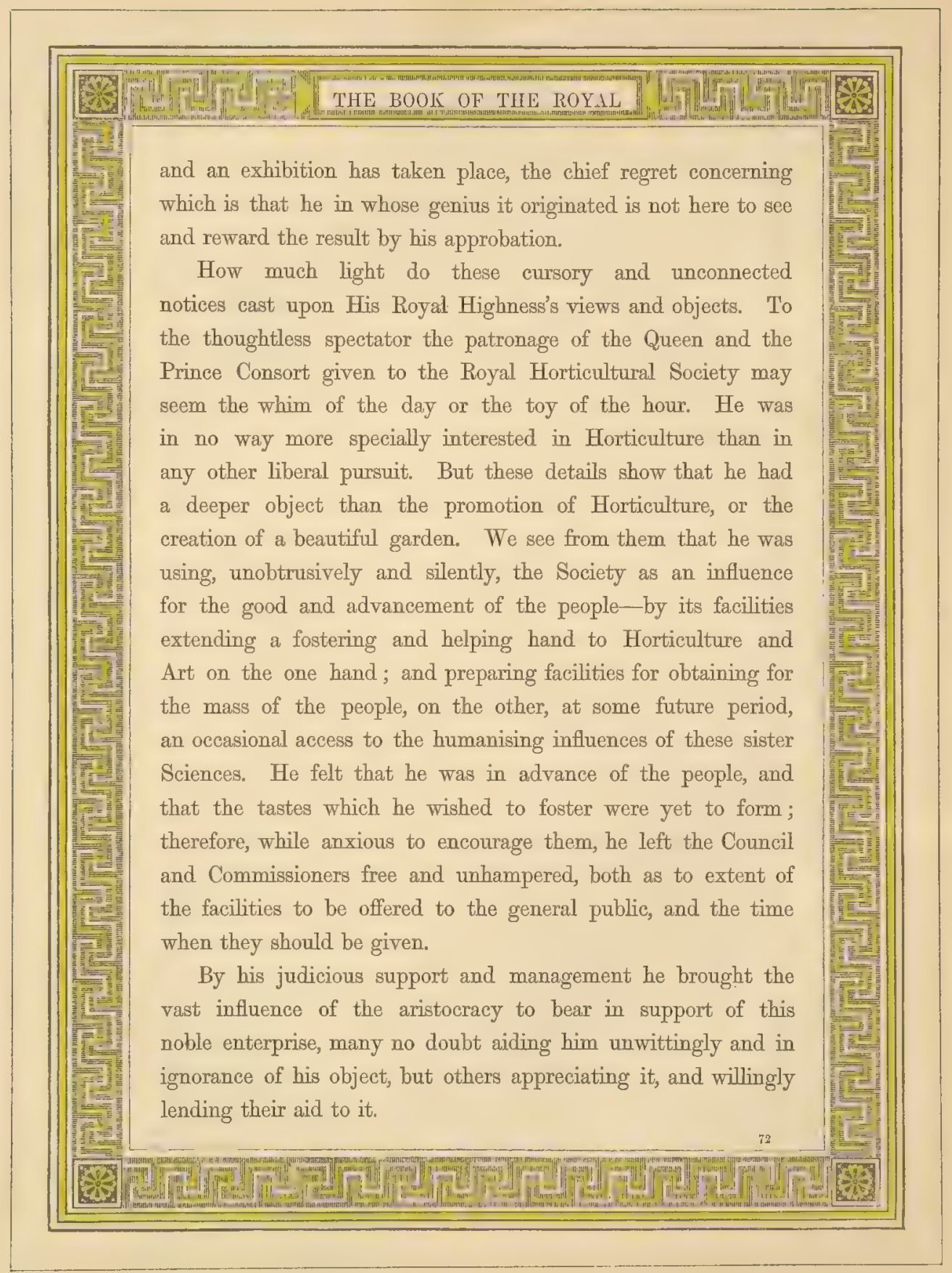




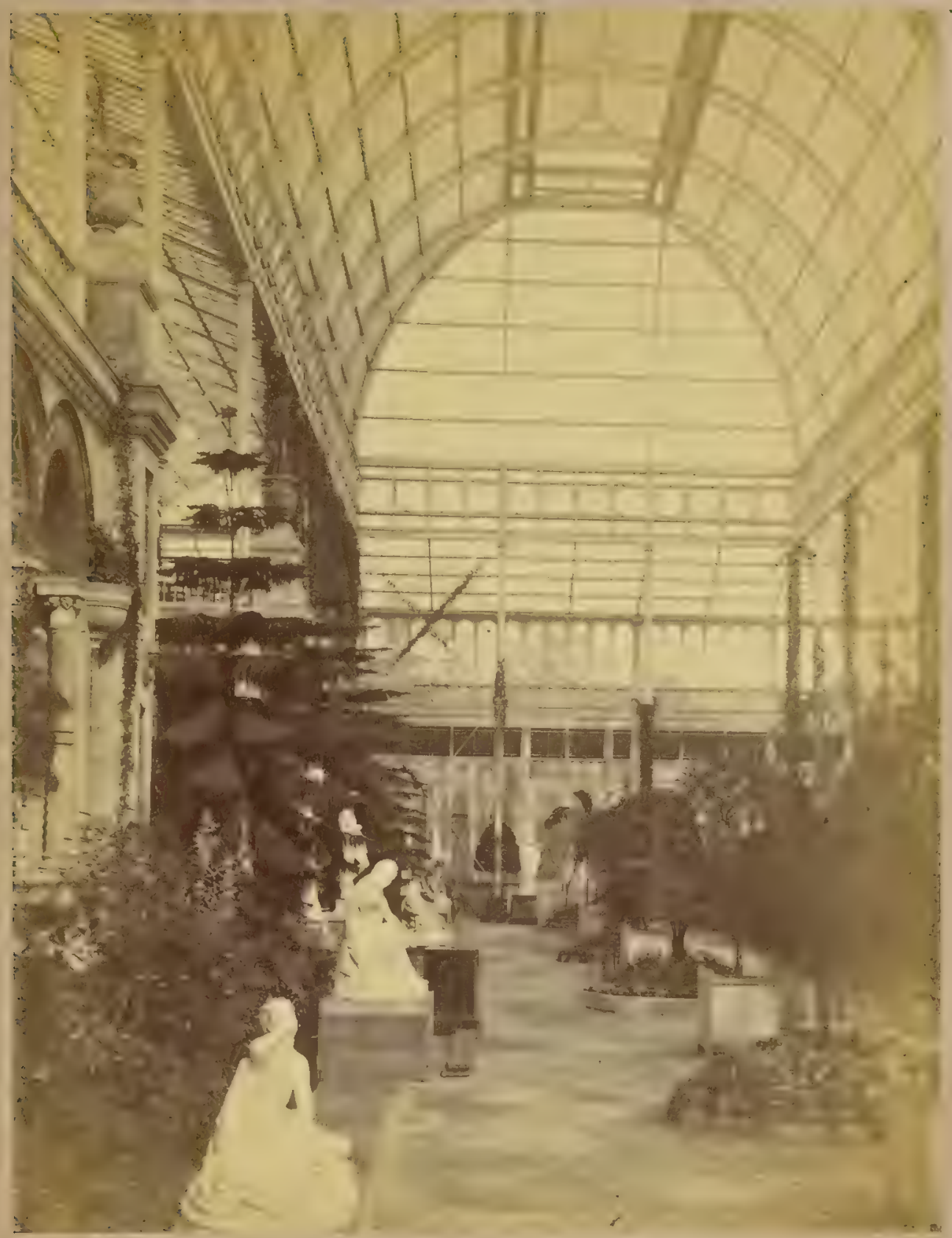




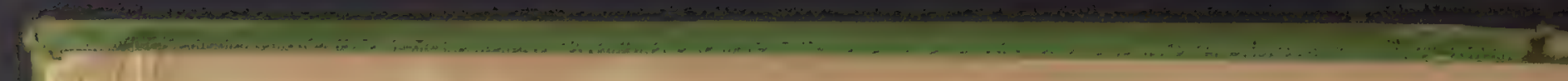




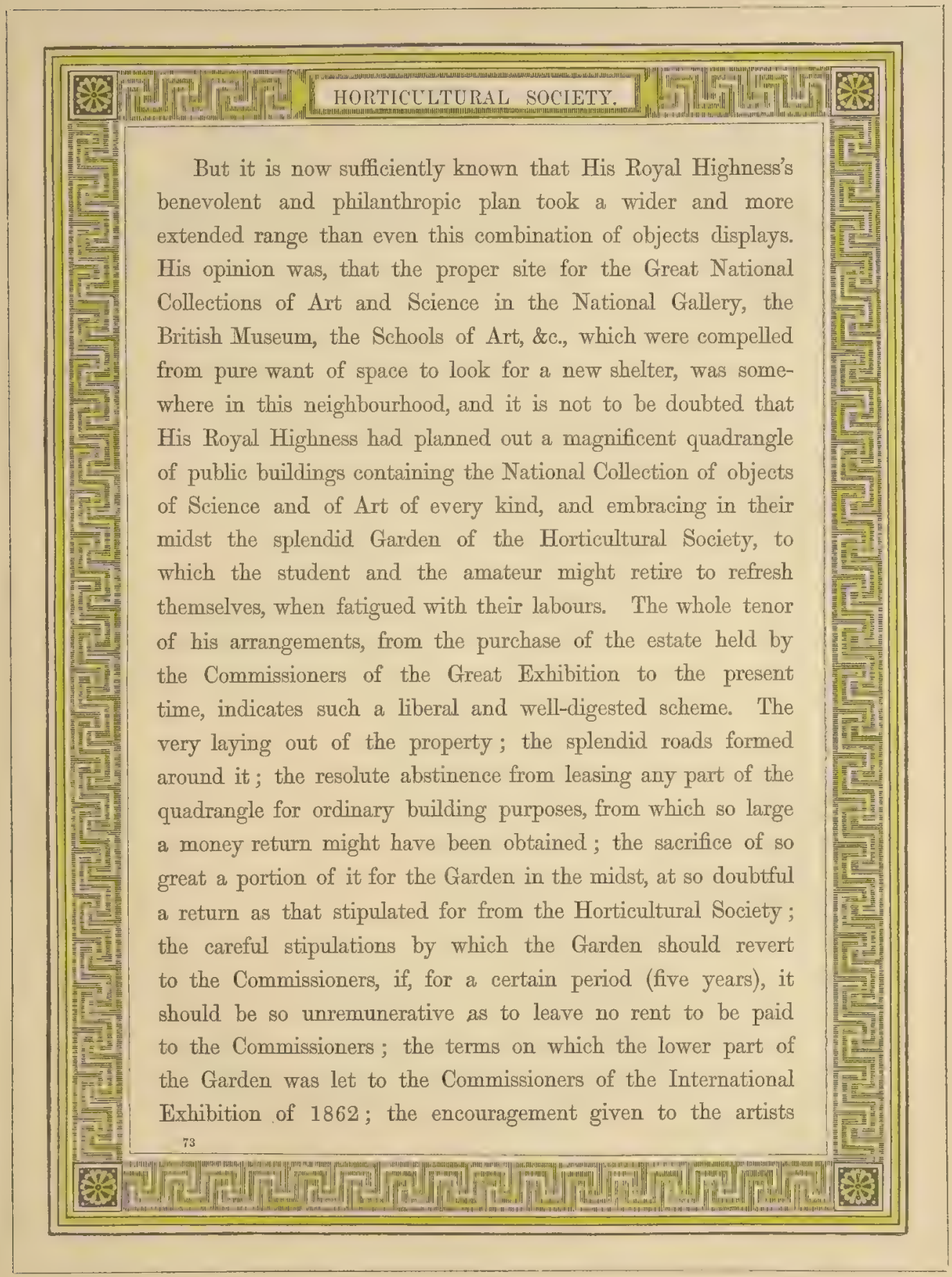




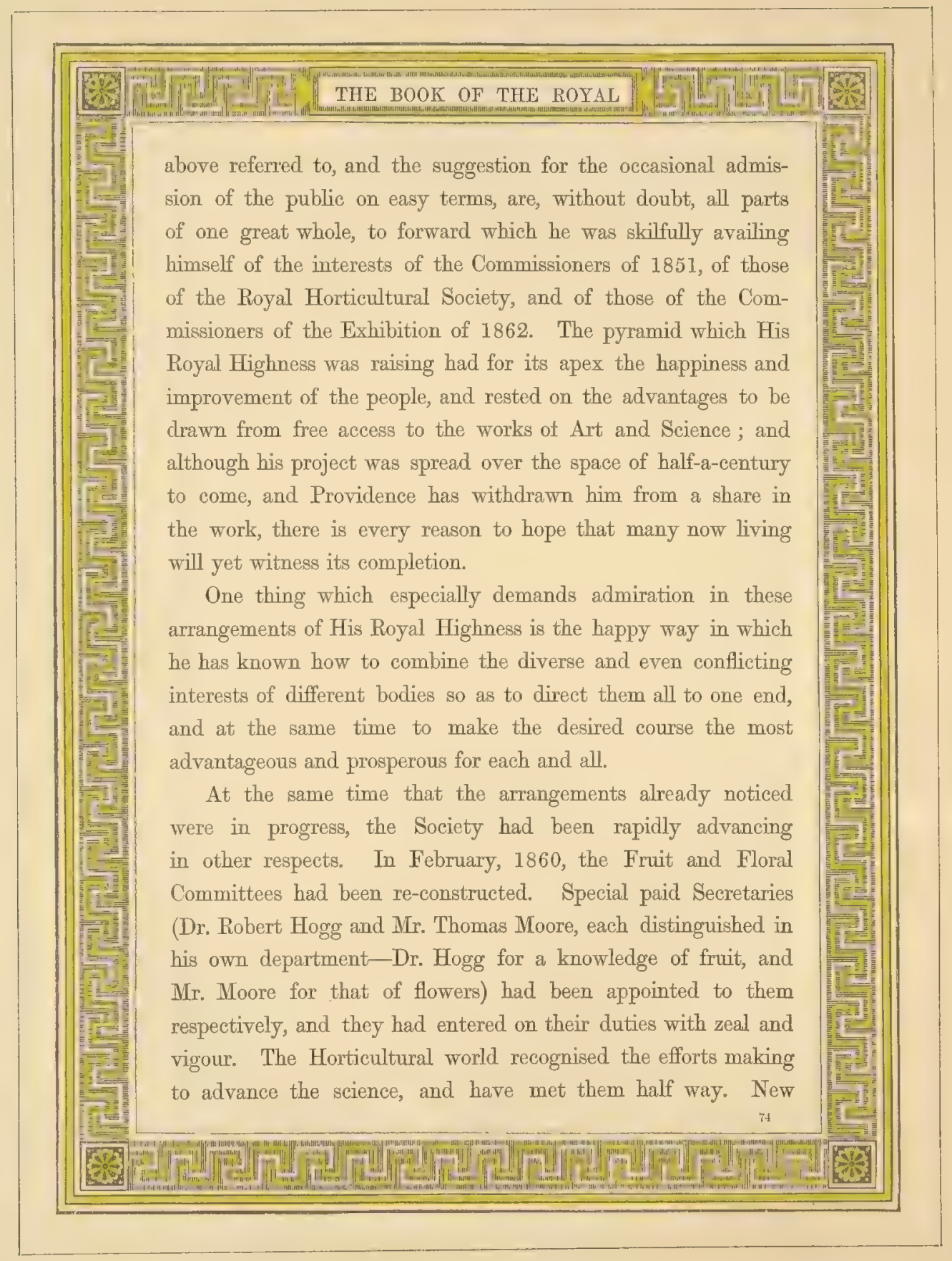




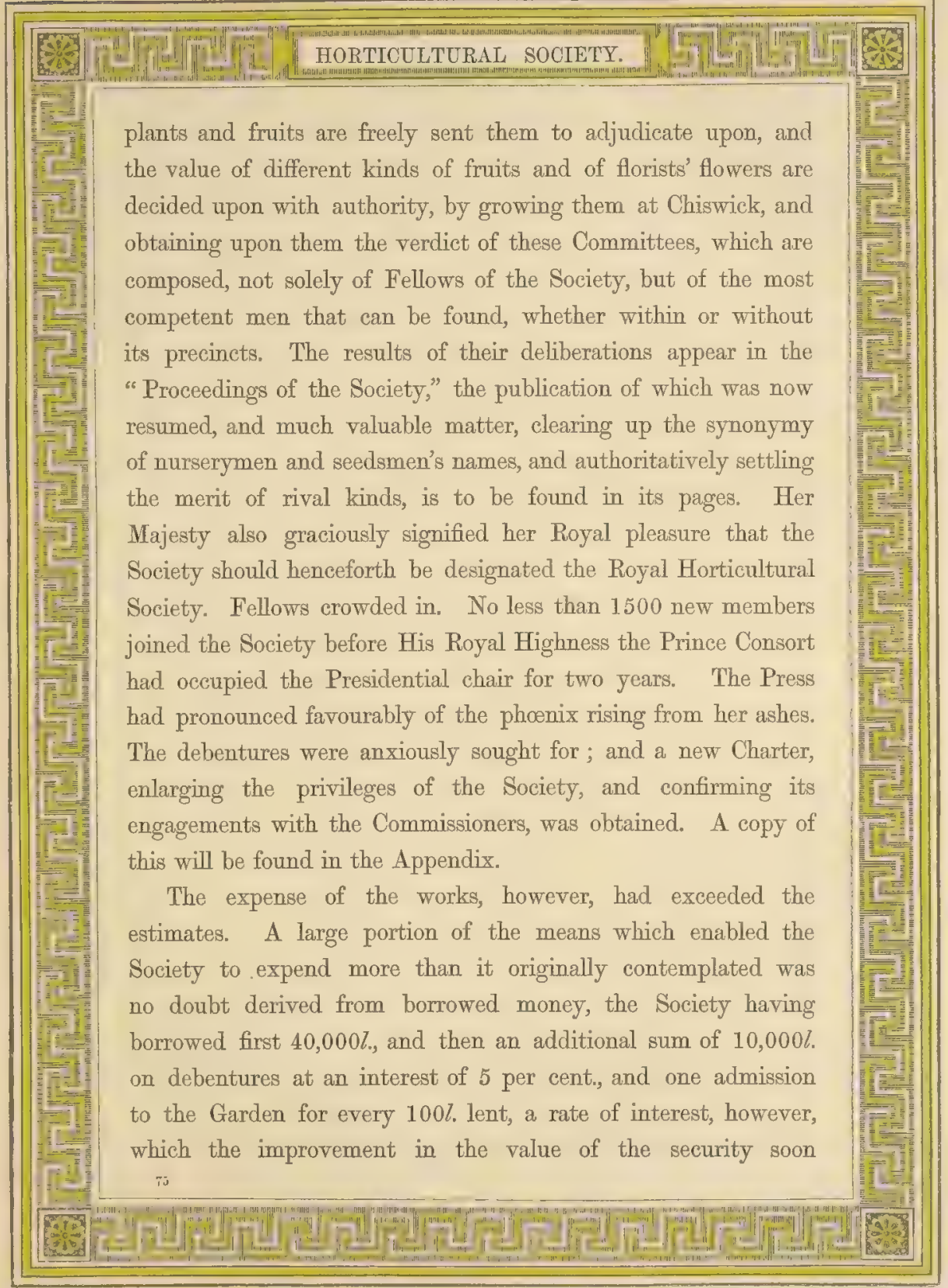


enabled the Society to get reduced to 4 per cent. But the large remaining sum of $20,000 \mathrm{l}$. had been wholly drawn from the subscriptions of the new Fellows.

The new Garden was opened on Wednesday, the 5th of June. It was opened by His Royal Highness the Prince Consort, and from that circumstance, and the sad bereavement which soon followed, everything connected with the event possesses a melancholy interest. It had been Her Most Gracious Majesty's original intention to have honoured the Society by opening it herself in state, and planting in it a tree, but the immediately preceding death of Her Majesty's lamented mother, Her Royal Highness the Duchess of Kent, rendered this impossible.

Early in the morning of that day, however, Her Most Gracious Majesty, in strictest privacy, accompanied by the Prince Consort and the King of the Belgians, honoured the Society with her presence in the grounds, inspecting the collections of flowers and fruit. At a later hour Her Majesty the Queen of the French, and His Royal Highness the Duc de Nemours, were also admitted to a private view. At one o'clock the gates were thrown open to an eager throng:

At this time the appearance of the Garden was most striking. The great Conservatory glowed with the brilliant colours of Azaleas, Orchids, Roses, and a multitude of other flowers, relieved by superb groups of Ferns, and all manner of parti-coloured or gracefully fashioned exotics, among which were exquisite specimens of the goldsmith's art in the form of vases, statuettes, and racing cups. Beneath the long colonnades, in endless profusion, extending many hundred feet, on either side were ranged superb masses of Pelargoniums and innumerable 


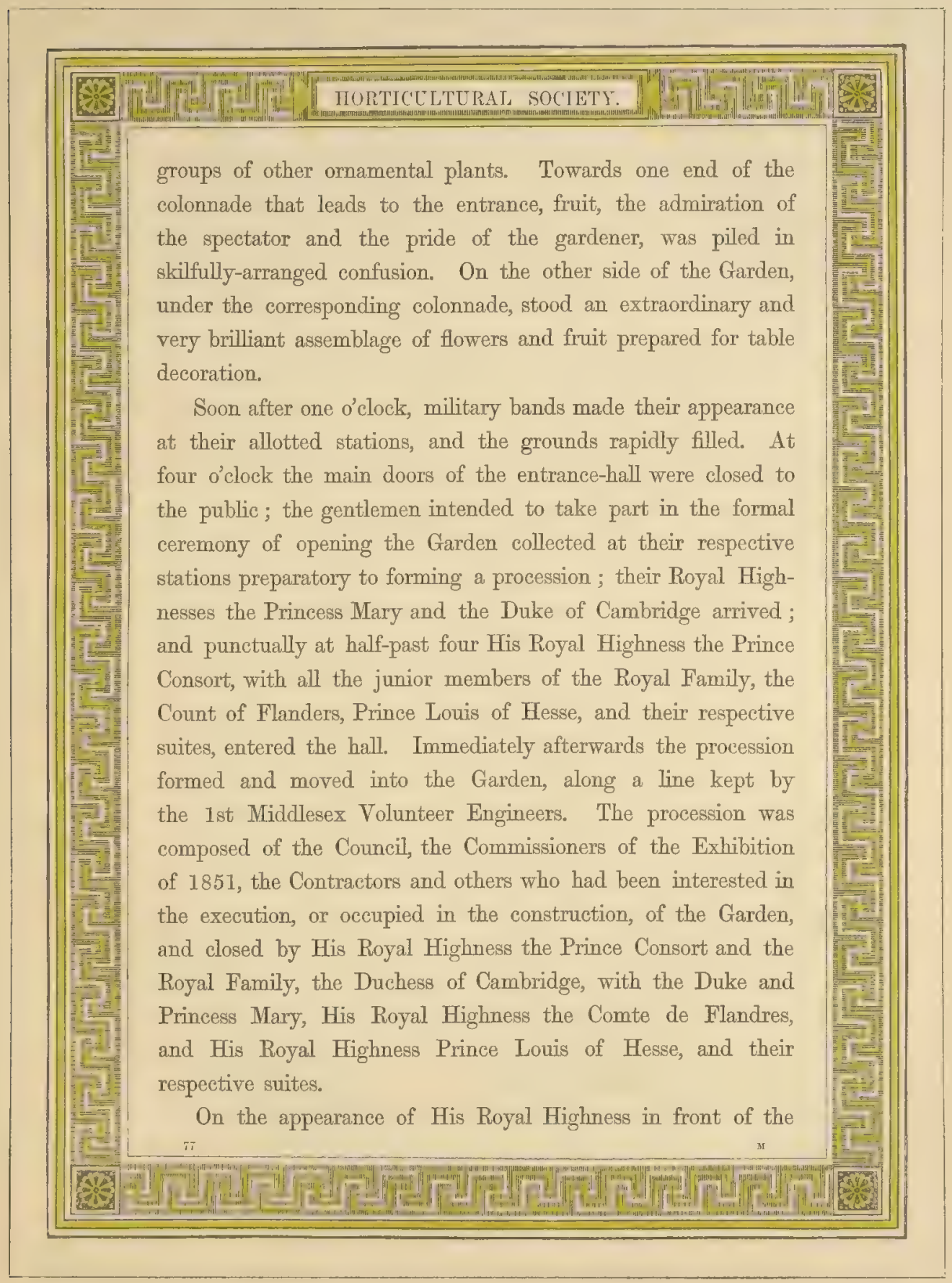


Council-room, at the top of the steps leading to the Garden, the Band of the Volunteer Engineers played one verse of "God save the Queen," the Royal party pausing on the landing during the time. The same Band then played the "Cobourg March" as the Royal party passed on until it reached the Second Terrace, when the Band on the West Terrace took up the March, and the procession moved up the centre avenue to the Conservatory. Here the procession halted in a space kept clear by police; the Royal party ascended the steps, and Dr. Lindley, the Secretary of the Society, read an address, briefly glancing over the past history of the Society, and its improved condition under His Royal Highness's auspices, and congratulating him on the success which had attended the undertaking. 'To this His Royal Highness the Prince Consort made the following gracious reply, viz.:--

"I thank you for the Address which you have just presented to me.

"While you have expressed your deep regret at being deprived, on this occasion, of the presence of the Queen, I am enabled and empowered to assure you that Her Majesty, on her part, also sincerely regrets her inability to mark by her presence the interest she takes in your proceedings, and her desire for your success.

"You have addressed me in my double capacity of President of your Society, and also of the Royal Commissioners of 1851 . In either of these capacities, I cannot but be gratified by the scene now before me.

"Having shared, to some extent, in your labours and anxieties, I am happy to be able to congratulate you on what 
has been effected in so incredibly short a time, effected notwithstanding the difficulties to which you have alluded, and which appeared at times almost to forbid hope of success.

"That which, last year, was still a vague conception, is, to-day, a reality: and, I trust, will be accepted as a valuable attempt, at least, to re-unite the Science and Art of Gardening to the sister Arts of Architecture, Sculpture, and Painting.

"This union existed in the best periods of Art, when the same feeling pervaded and the same principles regulated them all; and if the misuse and misapplication of these principles in later times have forced again upon us the simple study and imitation of nature, individual arts have suffered by their disjunction, and the time seems now arrived when they may once more combine, without the danger of being cramped by pedantic and arbitrary rules of taste.

"The Commissioners of 1851, whose mission it is to encourage the arts and sciences, as applied to productive industry, gladly welcome your Society as one of the first of those bodies, devoted to the promotion of special branches of these arts and sciences, that has availed itself of the enlarged means of development offered by the Commissioners on their estate. They are glad to find in your present success, and in the generous support of the public, the confirmation of their belief that in securing space on which, in unison with each other, and with a systematic interchange of mutual assistance, separate societies and departments might attain to a degree of usefulness which their present confinement and isolation must materially lessen, the Commissioners had correctly appreciated the great want of the day, and the requirements of the public, for whose 


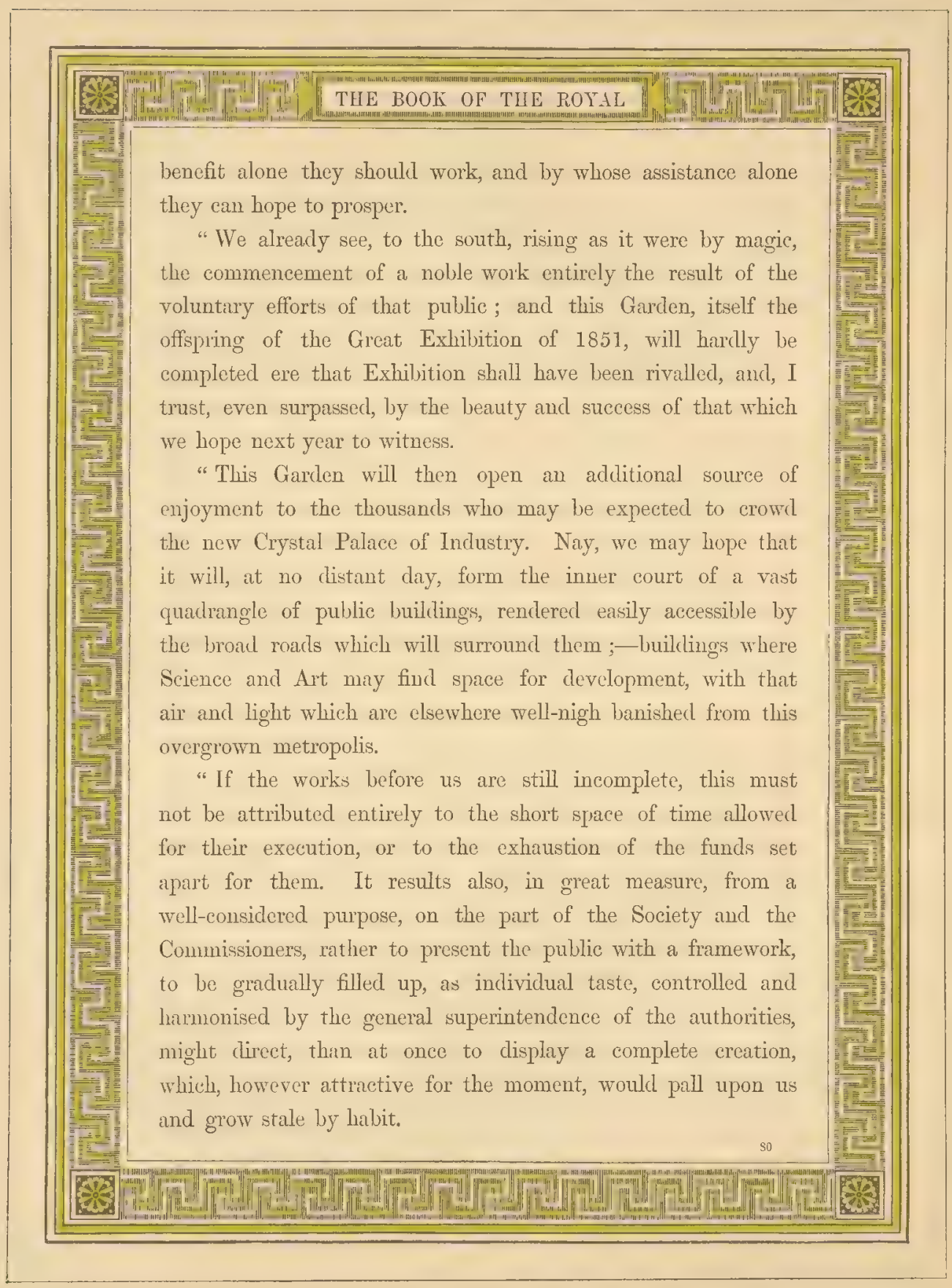


"Unrivalled opportunities are here offered for the display of works of Art, and for the erection of monuments as tributes to great men and public benefactors. The Memorial of the Exhibition of 1851, the result of private subscriptions, will be the first received in these grounds, and, adorned with a statue of the Queen, will soon rise in the centre of the Garden.

"May your efforts meet with public approbation. May that approbation give you all the support required, not only further to ornament these Gardens, but also to carry out, even on a larger scale than during the last forty-eight years, the useful objects for which you are incorporated."

Immediately afterwards, the Bishop of London, who was attended by the Archdeacon of Middlesex and his Chaplain, offered up suitable prayers for a blessing on the undertaking.

The Prince Consort then stepped forward, and in a loud voice declared the Garden to be Opened, amidst the cheers of the surrounding spectators.

The procession next proceeded to a point near the northeast corner of the Arcades, where a tree was to be planted by the Prince Consort, in commemoration of the occasion. A fine Wellingtonia gigantea, the gift of Messrs. Veitch, had been selected for the purpose. Dr. Lindley, in the "Gardeners" Chronicle" of the week, thus describes the scene: "Surrounded by the Council and other members of the procession, His Royal Highness, having received a spade from a bystander, threw some shovelfulls of earth over the roots for himself and the Princesses, his daughters. The Princes acted for themselves, not the least skilful among them being Prince Arthur, who handled the spade with a vigour that showed him to have used well the $\$ 1$ 


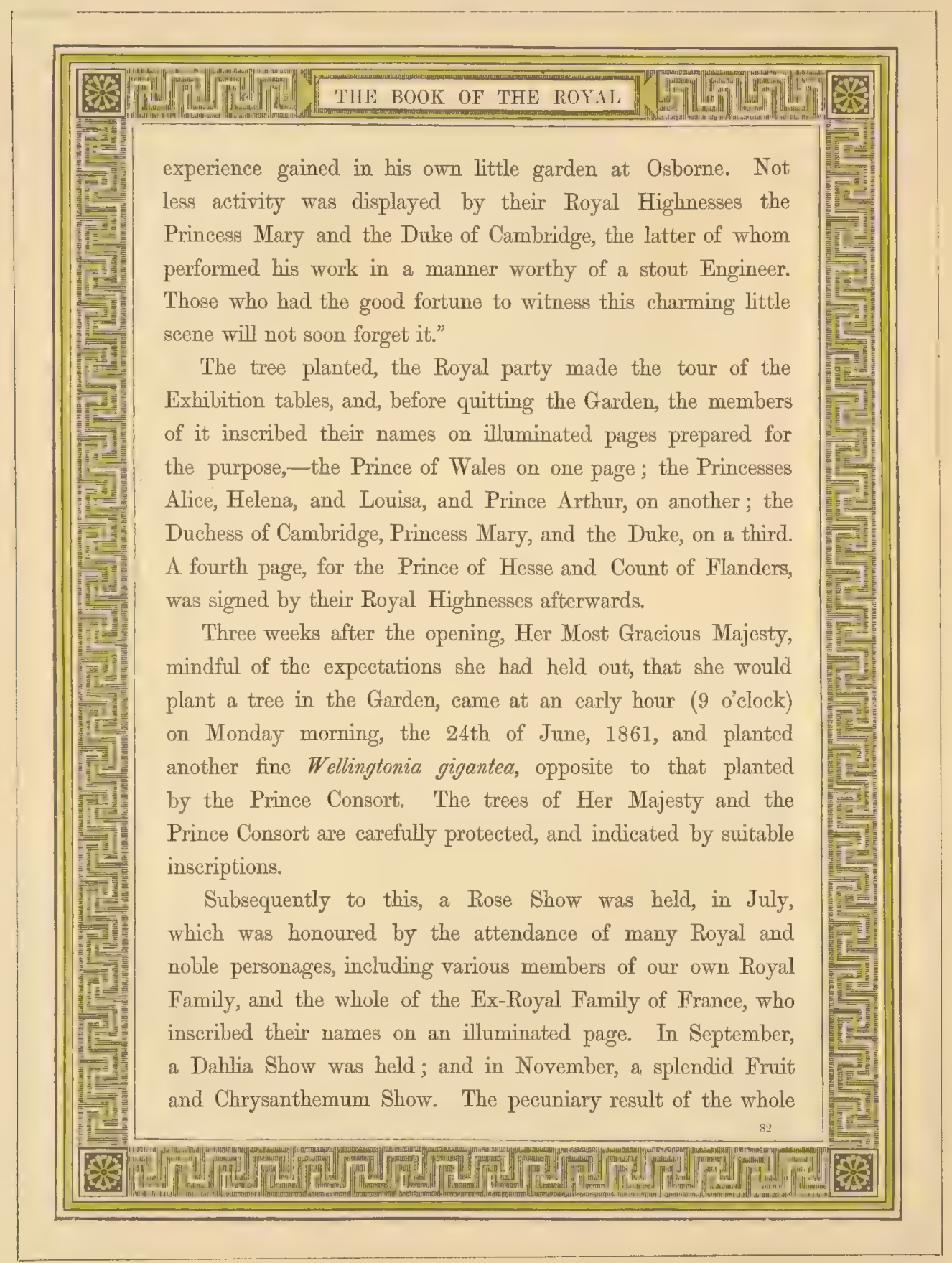




shows of the season was a profit of 1347l, after paying
expenses. His Royal Highness was at Balmoral when the
September Show was held, but periodical reports of all that
was going on were regularly furnished to him. The scheme
for the year 1862 was then in preparation, and he studied it
in all its parts. Immediately after his return from Scotland,
his first visits were to the Garden. He was there on the
morning of the November Show, and passed some hours in
the adjustment of various points relating to the statuary and
architectural embellishments of the Garden, which had been
executed or were in progress since his last visit. One thing
which had been executed was the pedestals of the small statues
at the Maze; these he wished to be slightly altered, and their
position moved a few feet. Another matter which did not
please his critical eye was the border of the red panels on the
low revêtement walls beside the canals. The design had been
submitted to him, but when he saw the work done it did not
please him. On the occasion in question, he gave instructions
to the Assistant-Secretary to have it altered, and replaced by
another in "Greek Keys," at his own expense. Several designs
were sent to him, and that which was chosen, and is now
placed as a border to the panels, is the same as surrounds this
page. It was the last order he gave to the officers of the
Society: he selected it on Saturday, the 29th of November,
and was taken ill on the 30th; and the design has been used
as a mourning border for this chapter, in melancholy remem-
brance of his latest command. On the 14 th of December, His
Royal Highness breathed his last. A nation's grief accompanied
him to his tomb, and, the instinct of a people's justice, has
s.




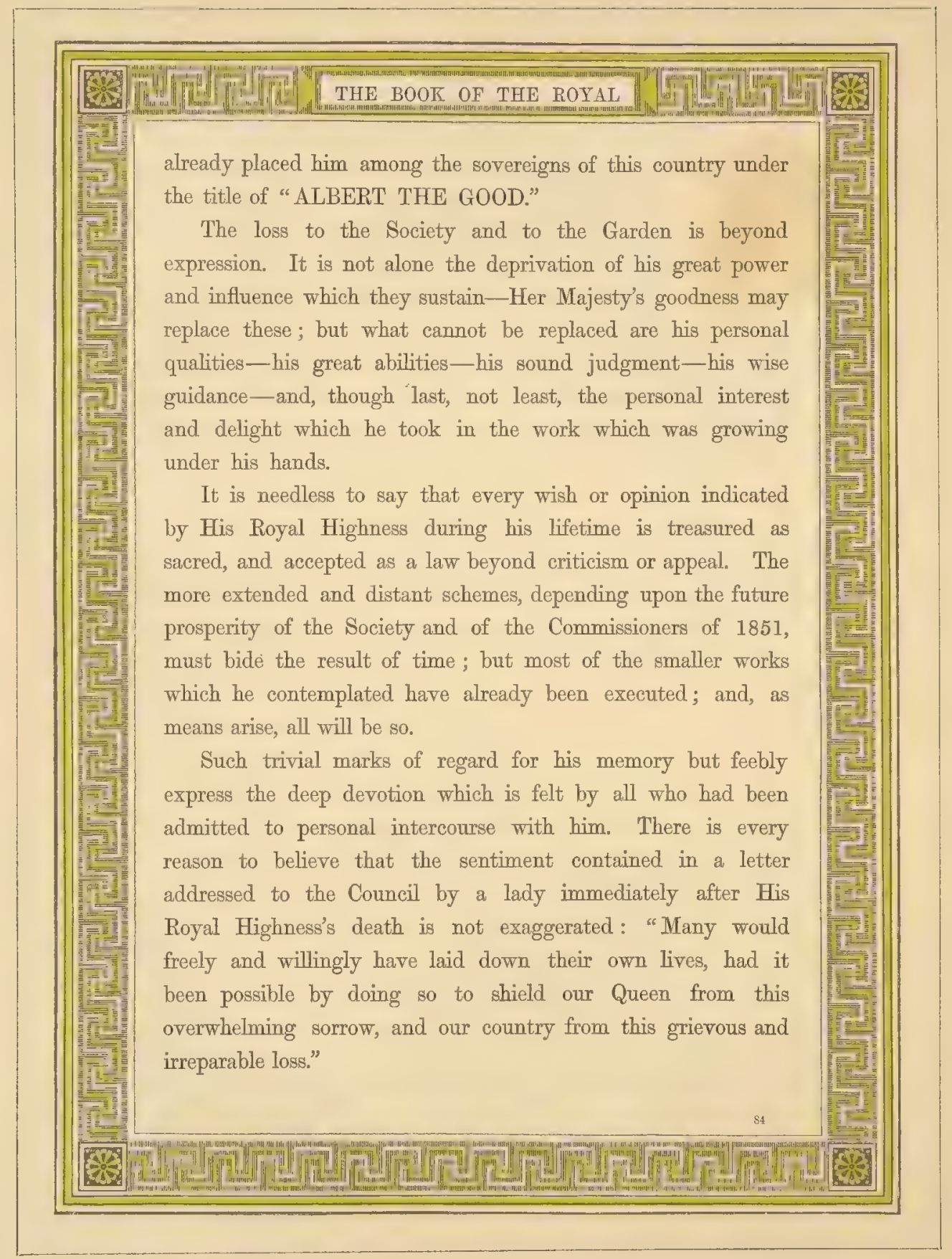




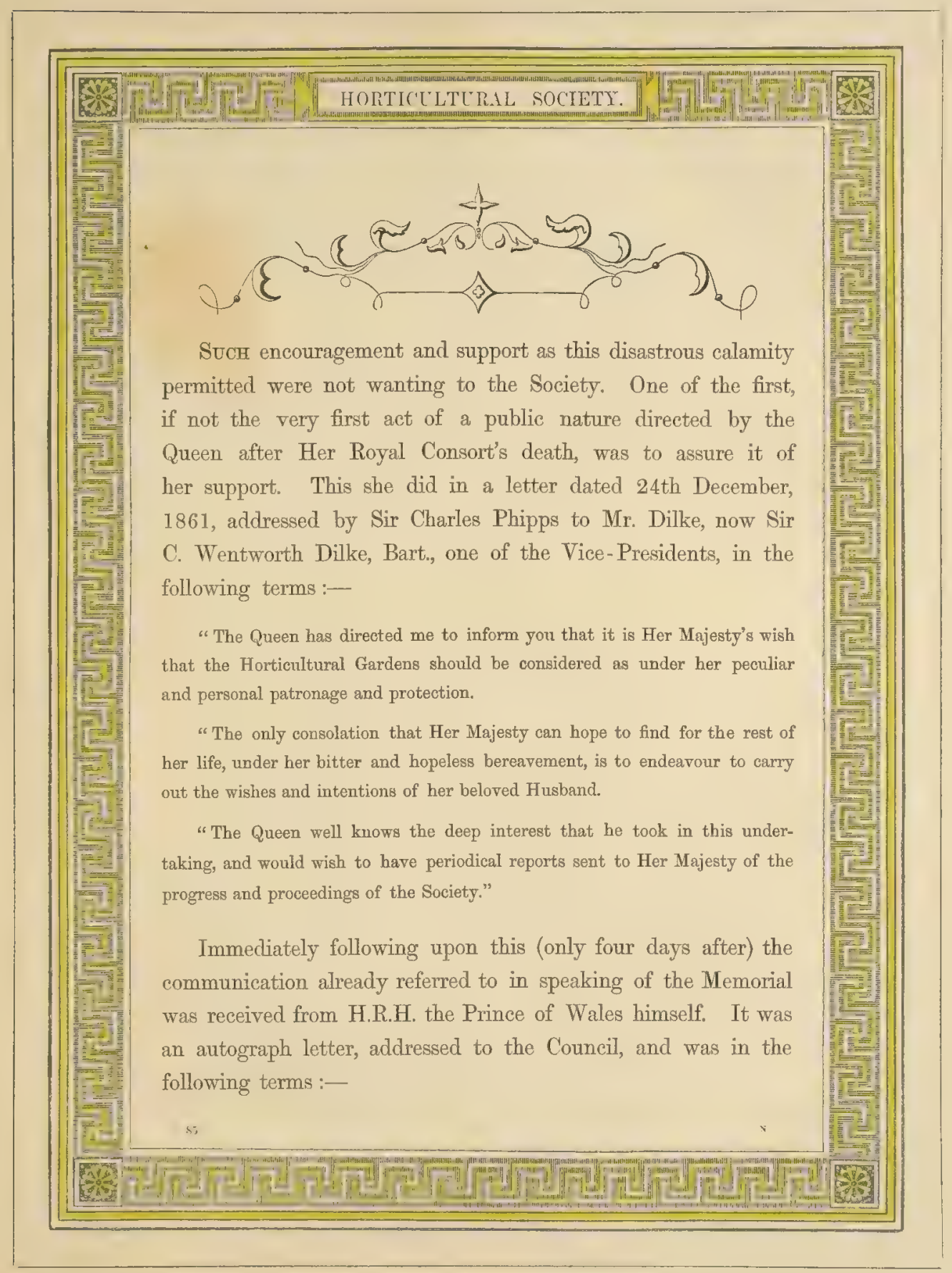




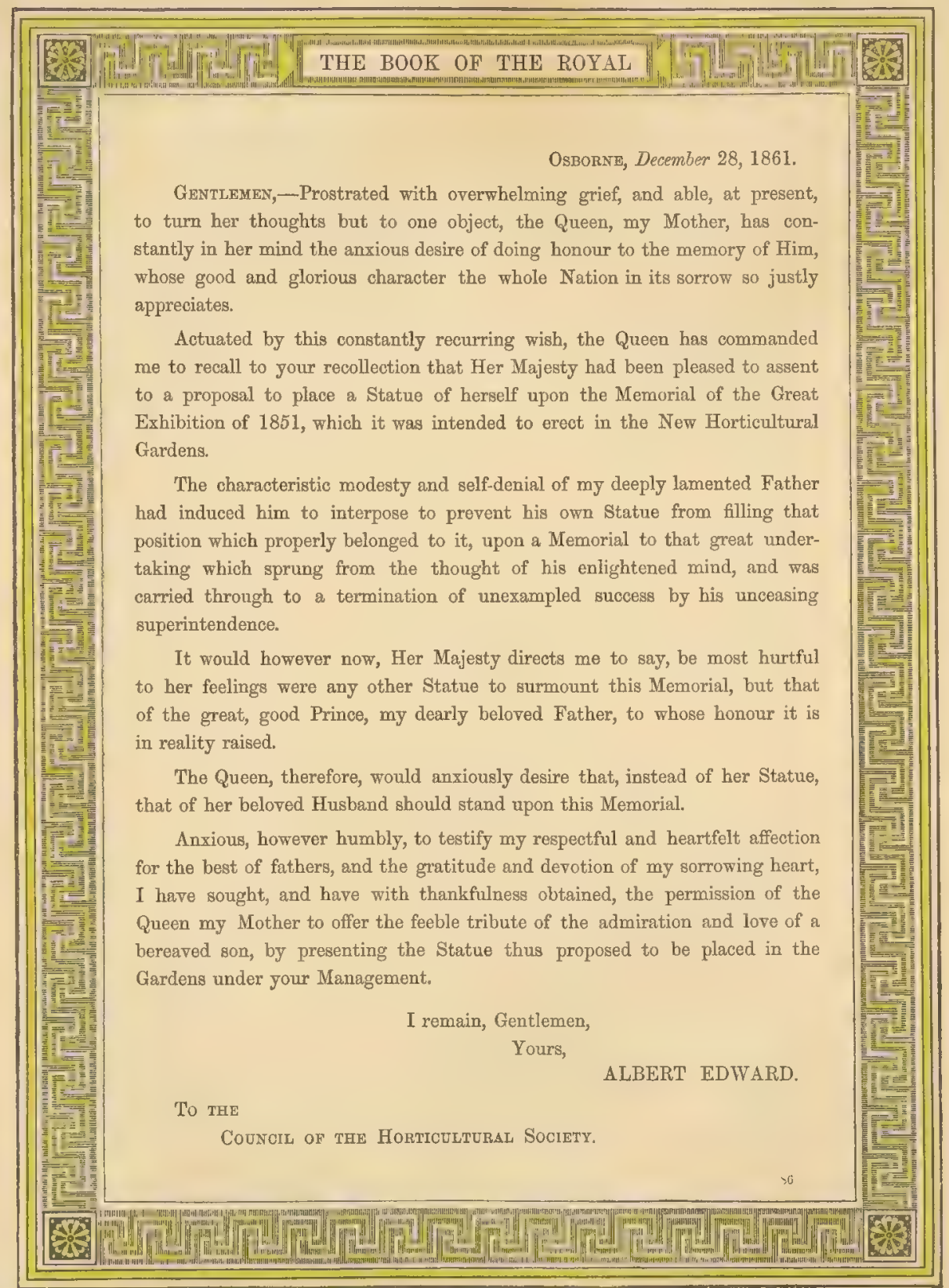




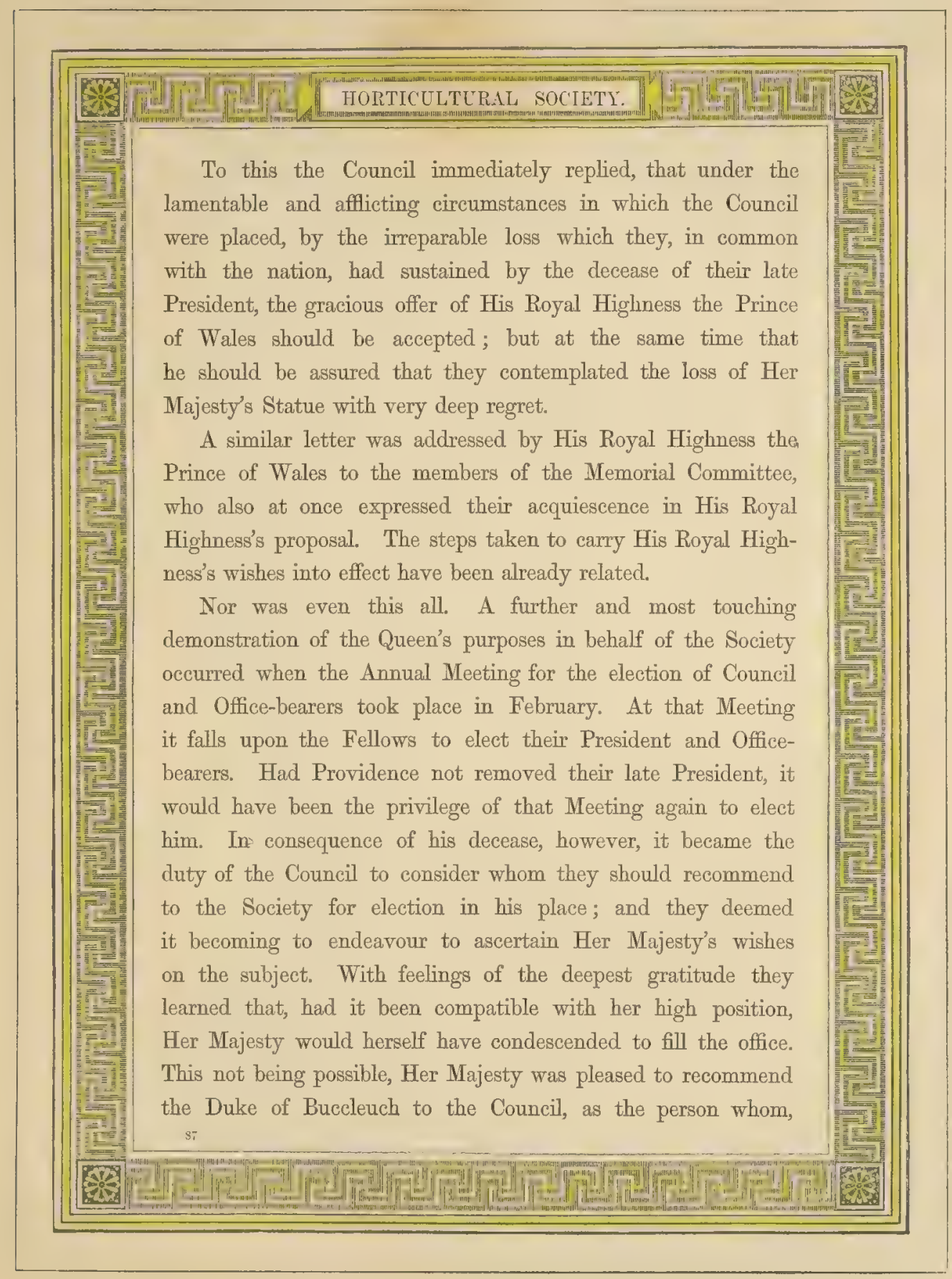




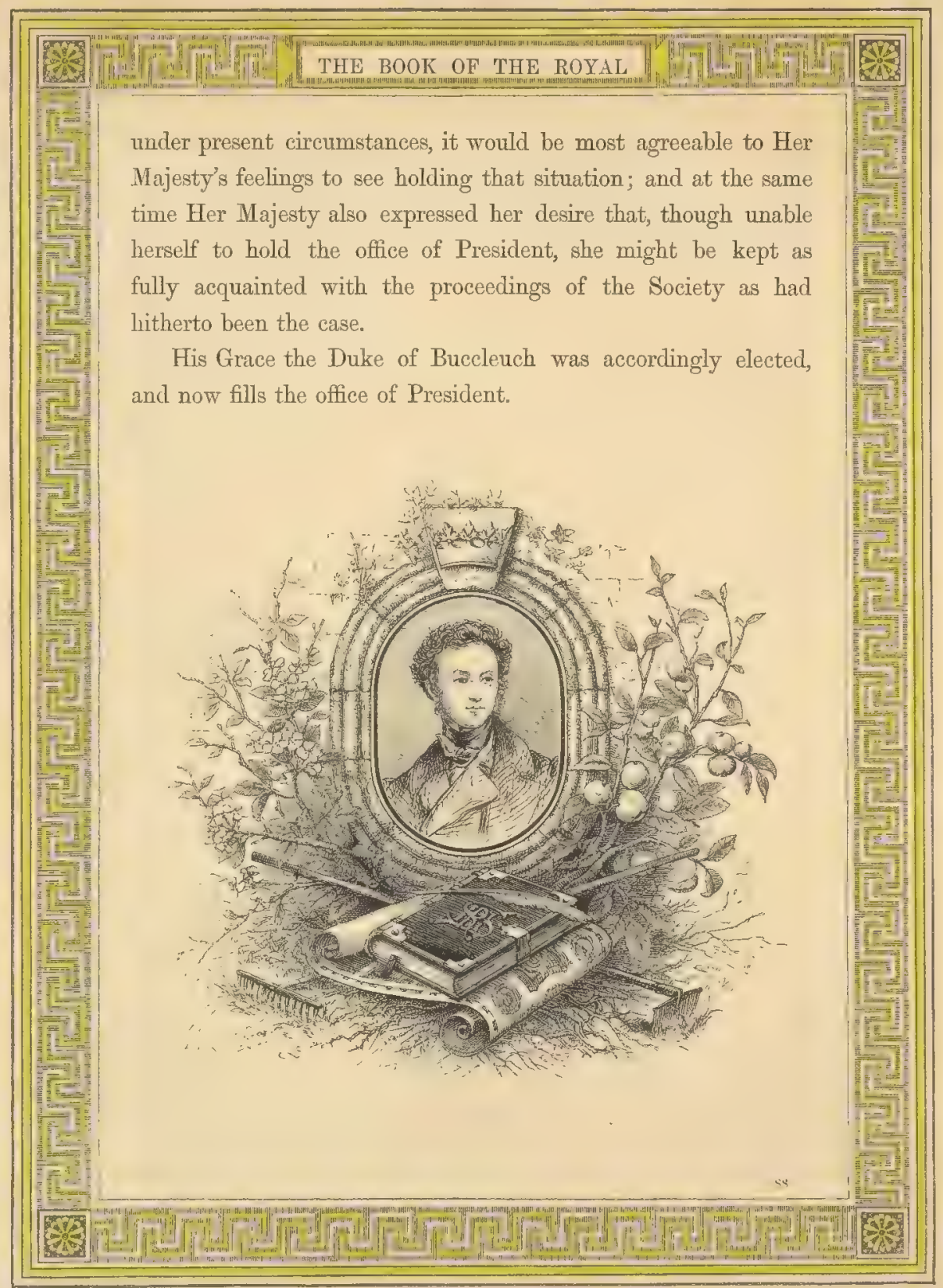





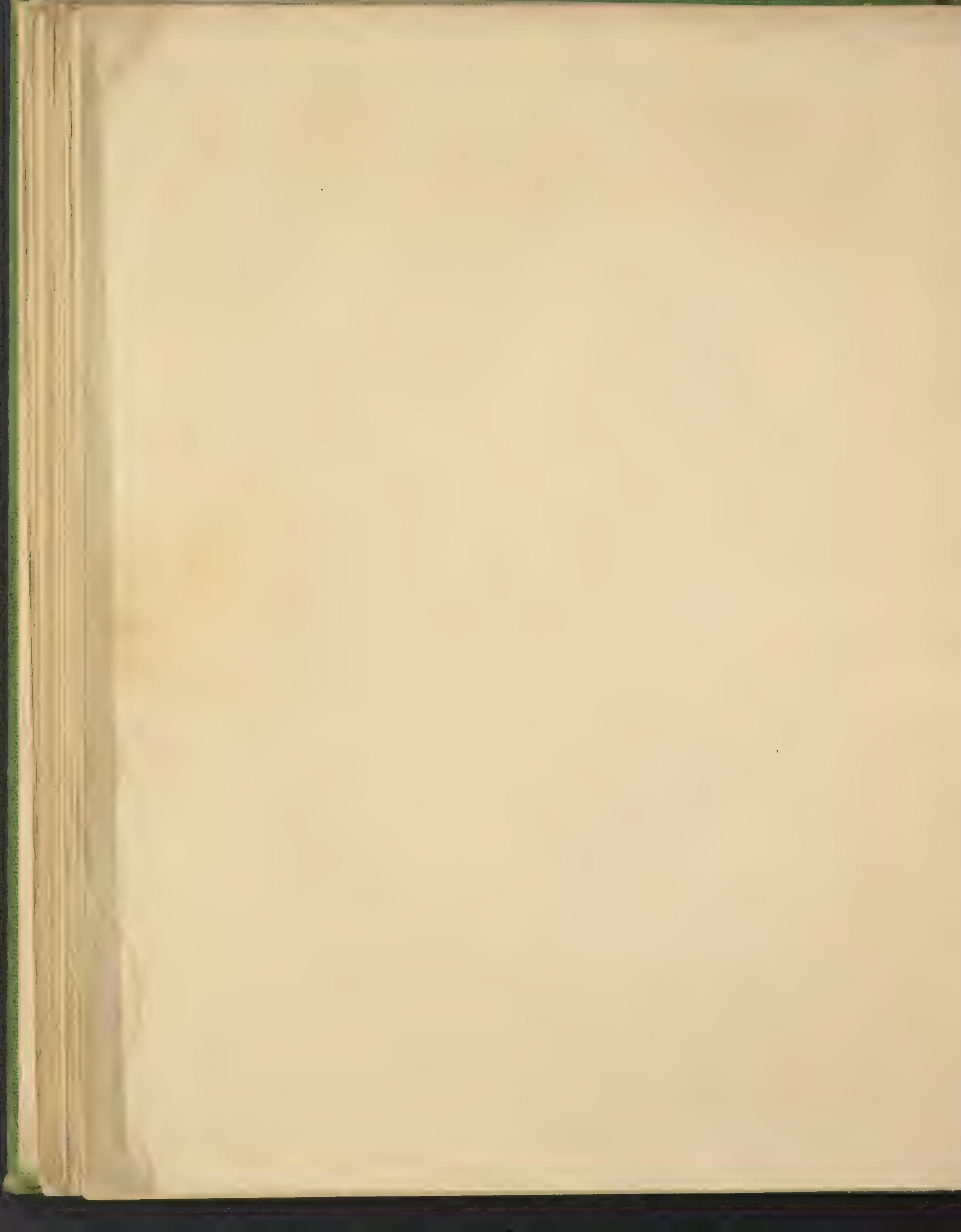




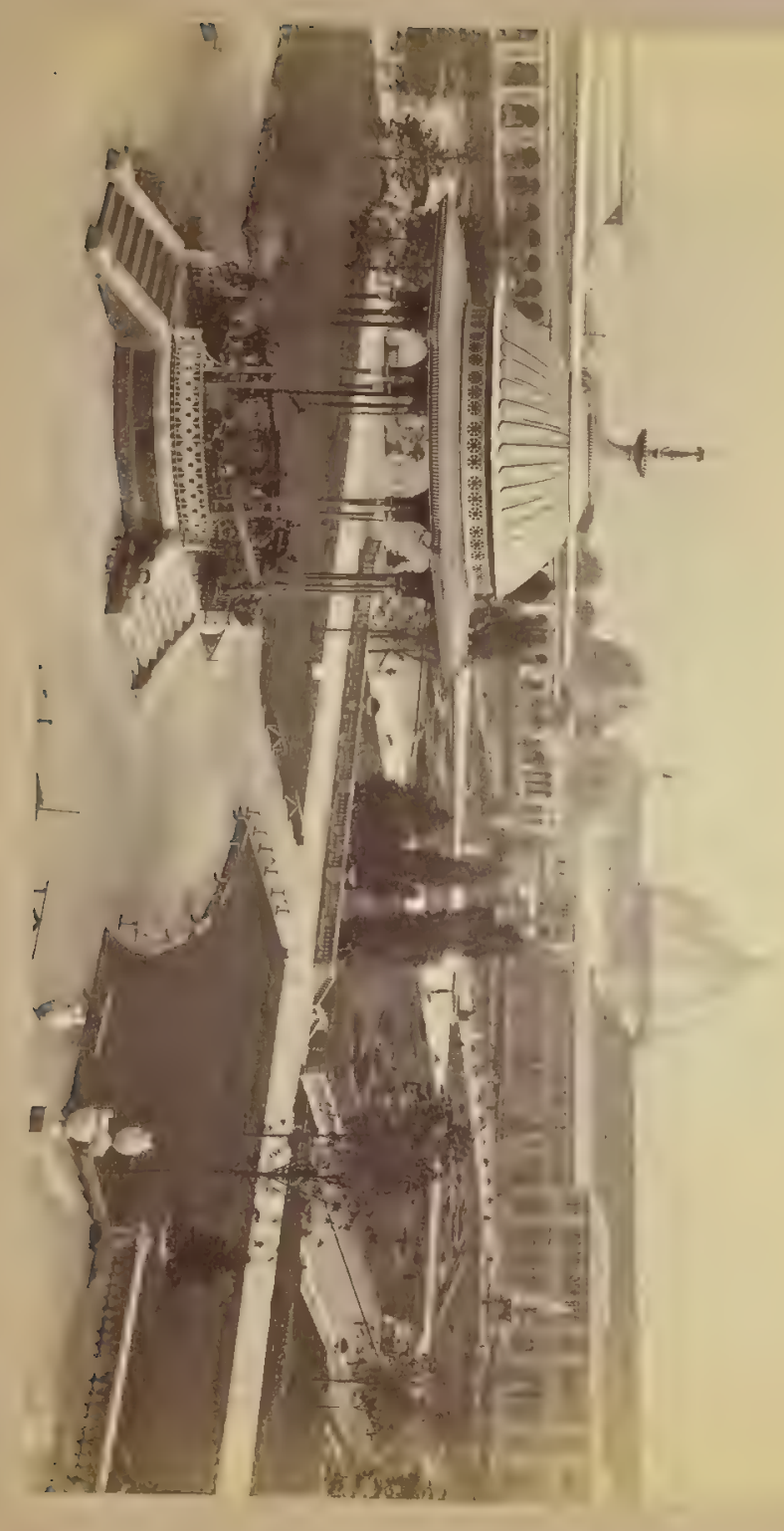




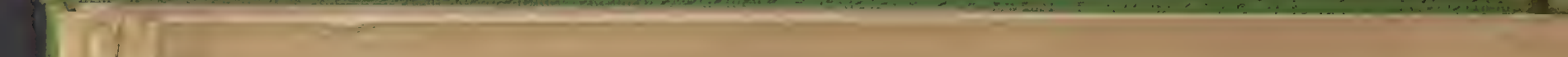




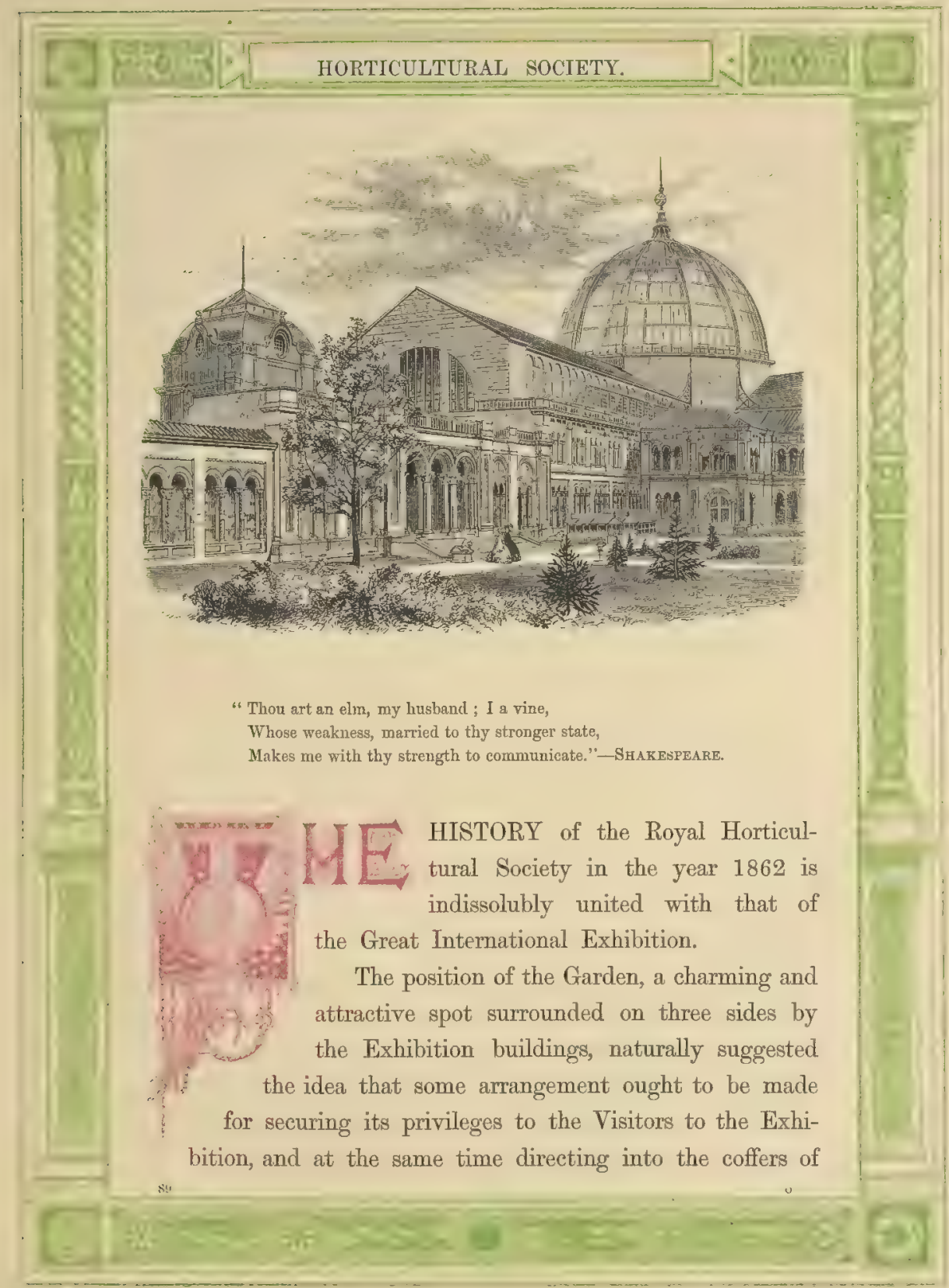




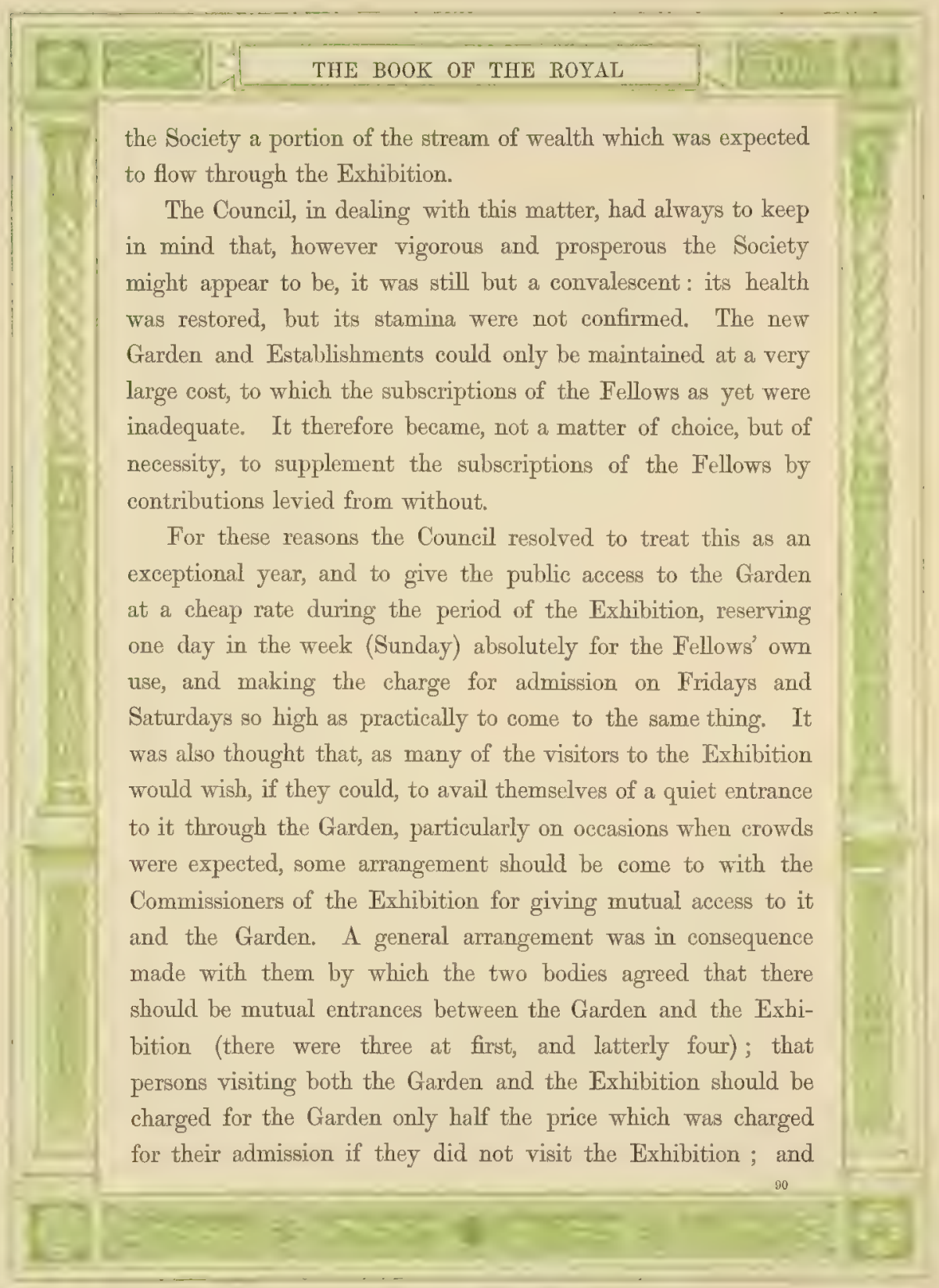




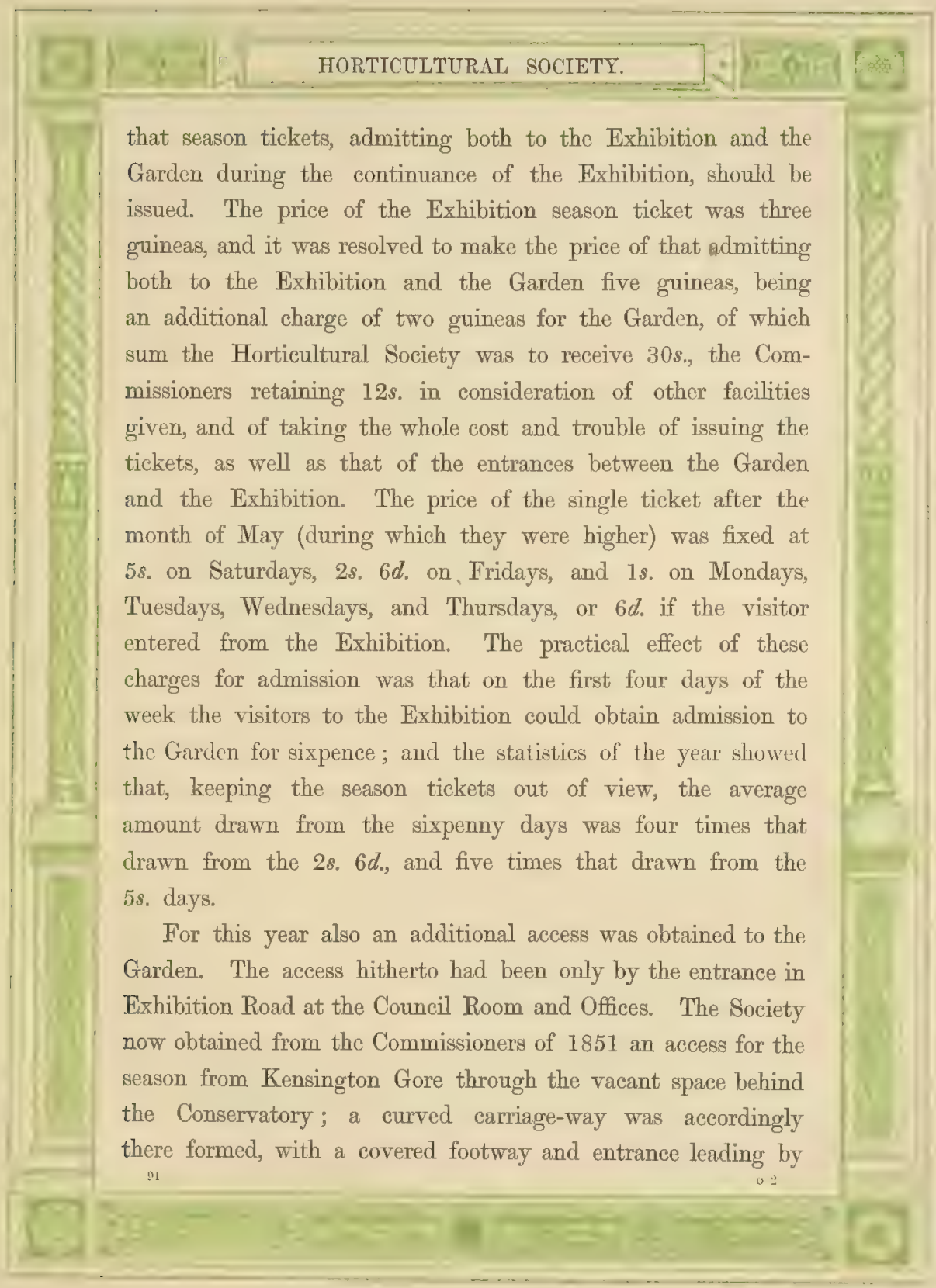




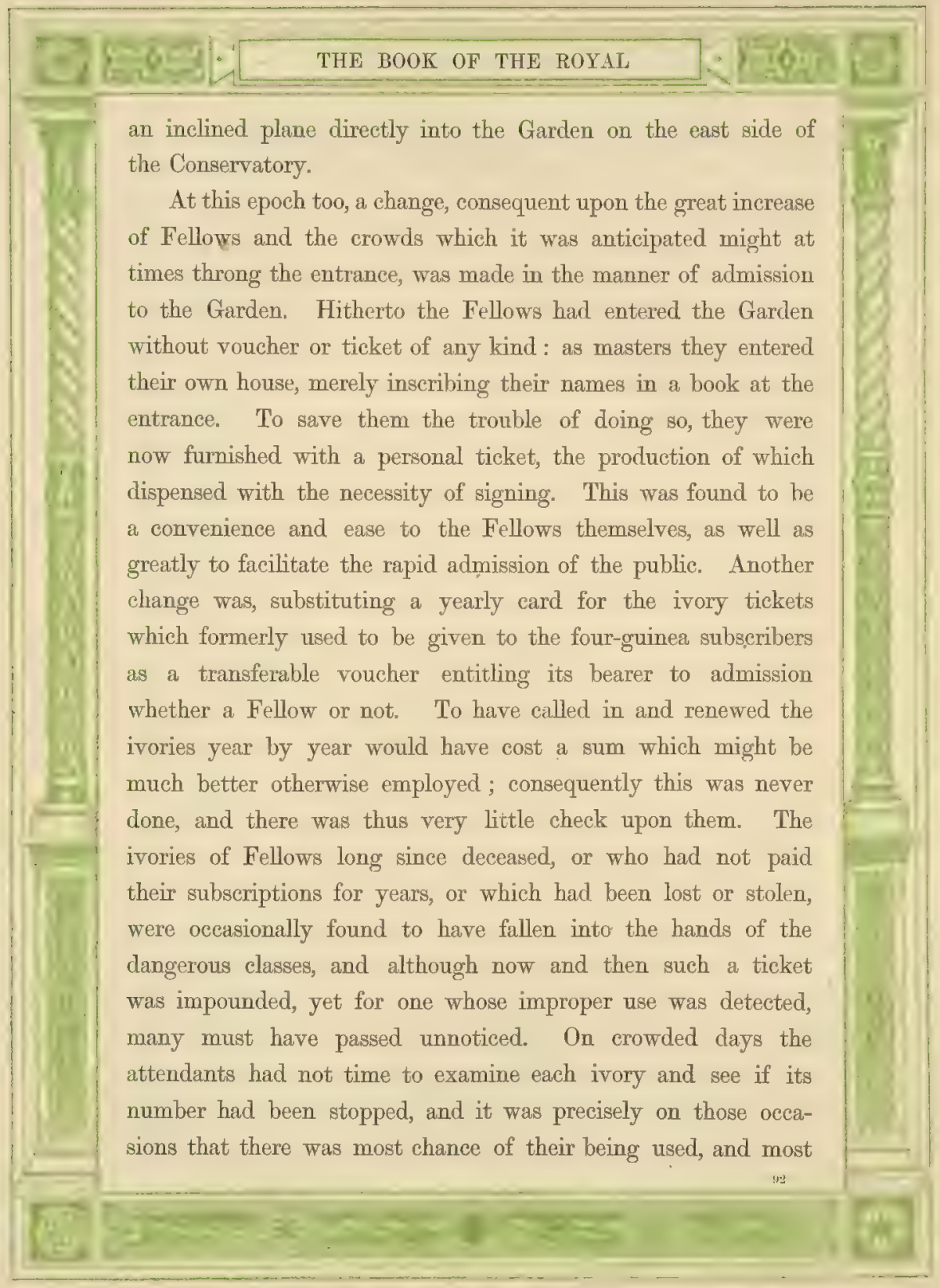




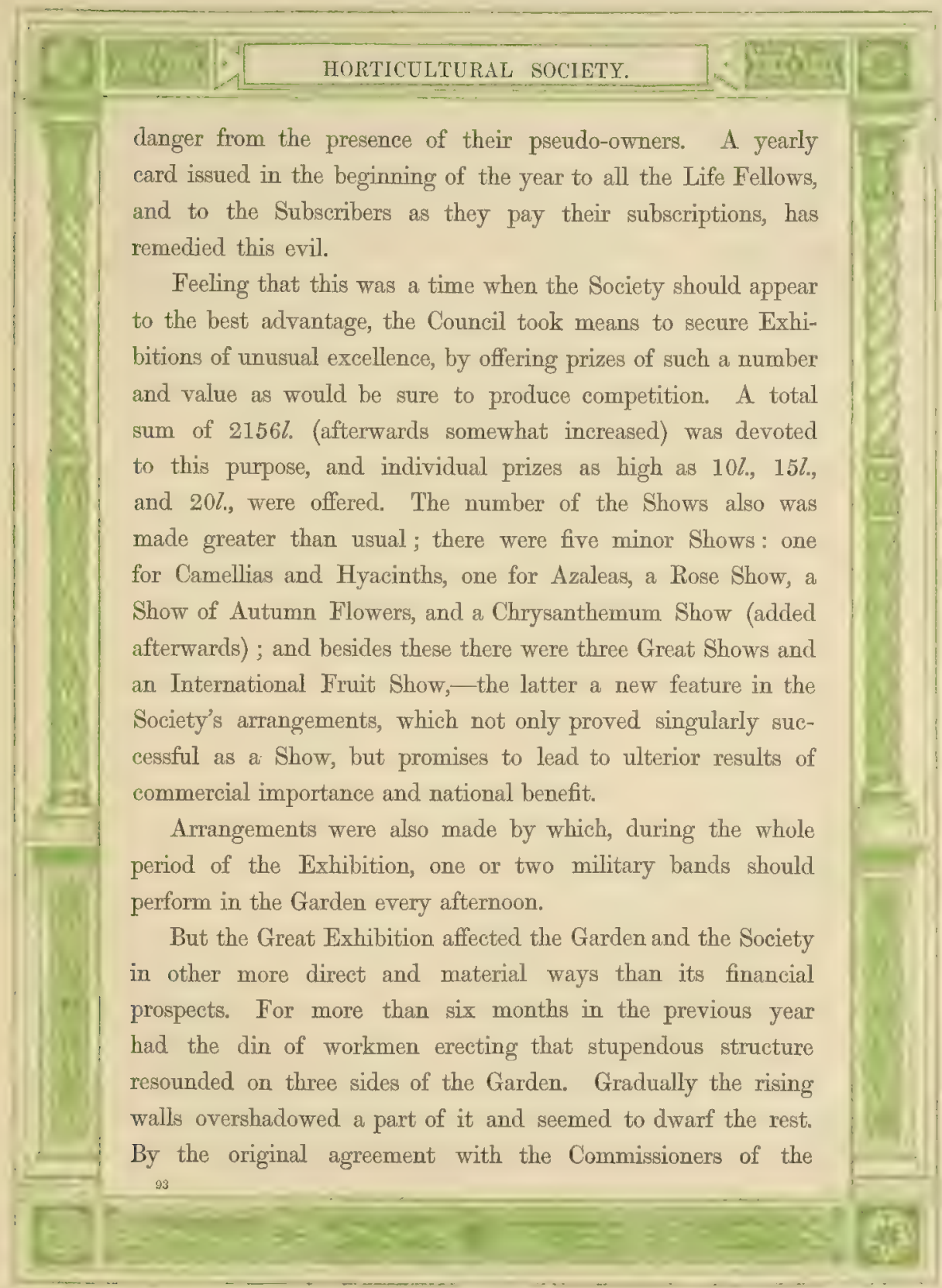




THE BOOK OF THE ROYA
Exhibition of 1851 , the right of placing stalls for the sale of
flowers, and similar objects, in the Southern or Lateran Arcades
had been reserved to the Commissioners, the interest of the Society
in them being limited to a right of promenade along them and on
their roof ; the intention being that a continuous walk should
extend all round the Gardens on the top of the areades. The
experience of the walk on the top of the Upper or Albani
Arcades has shown, however, that such a promenade was not
greatly prized, few people going up except to show the view to
their friends and then descend again.
When the Exhibition Building was being planned, a recom-
mendation was made by their architects to the Commissioners
of 1851 to erect an upper story on the top of the Southern
Arcades (to be used as refreshment-rooms during the Exhibition).
This of course could not be done without the consent of the
Council, but on application being made it was granted, and the
Commissioners of 1851 succeeded in making an arrangement
with the Commissioners of the Exhibition of 1862 by which this
story was to remain their own property after the close of the
Exhibition. To this arrangement is due the facade which
now furnishes a happy termination to the lower part of the
Garden. The the International Exhibition also the Society next owed
the offer for exhibition in the Garden of a variety of works of art
which had either been refused by the Commissioners of 1862 or
were too large to be contained in the building. As may be sup-
posed, the Council were not ambitious of converting the Garden
into a refuge for the destitute; and therefore, although they
did not pin their faith on the judgment of the Commissioners
19.


and their advisers, and all offers were fairly and impartially considered by their own Fine Arts Committee, still its having been rejected by the Commissioners did not by any means increase the chance of any work being accepted for the Garden. In point of fact there was no instance where an object rejected by the Commissioners on the score of quality found its way into the Garden. It was not so with those which were rejected for want of space : of these some were rejected, but more accepted ; the most prominent of which were two French fountains; both of the same material -iron, painted bronze; new in design and construction, having been prepared expressly for competition at the International Exhibition, and, although not quite of the same dimensions, sufficiently near in size and character to allow of their being placed in juxtaposition to each other, one on each side of the central walk between the two lower terraces, without destroying the symmetry of the Garden.

The circumstance of two large fountains having been offered for exhibition in the Garden tempted the Council into accepting both, and so almost necessitated their being thus treated as a pair. Had only one been offered or only one accepted, it would. have been placed in the central plot of the ground called the Ante-Garden, - a spot which had been laid down for a large fountain in the original plan. Where they were actually placed, two small basins had been projected; but the place for the fountain was in the centre of the Ante-Garden.

When these were first offered to the Council for exhibition in the Garden, the offer was accompanied with a condition that the Society should be at the expense of erecting and working them. On inquiry, it was found, in the first place, that a sum of 


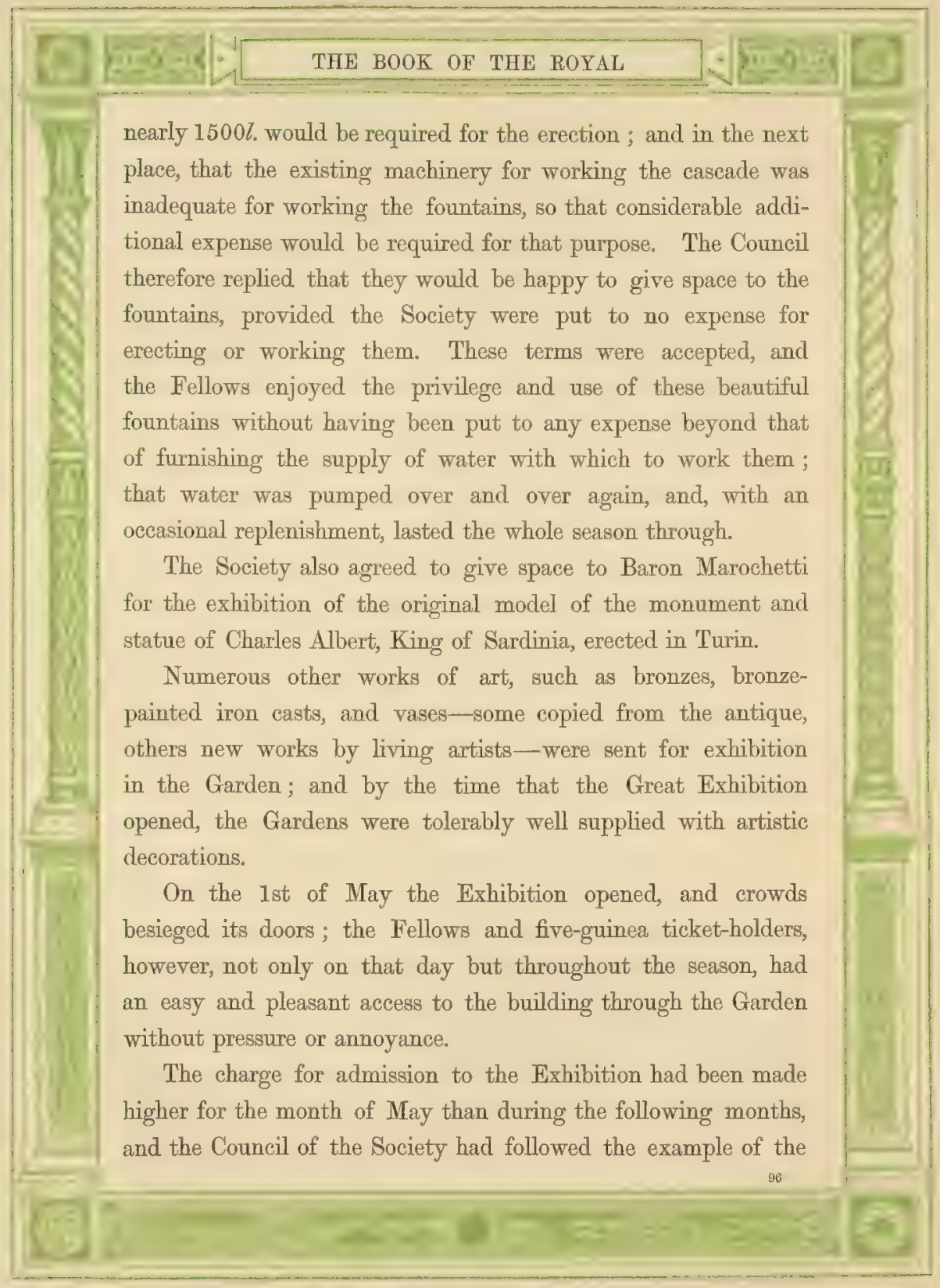




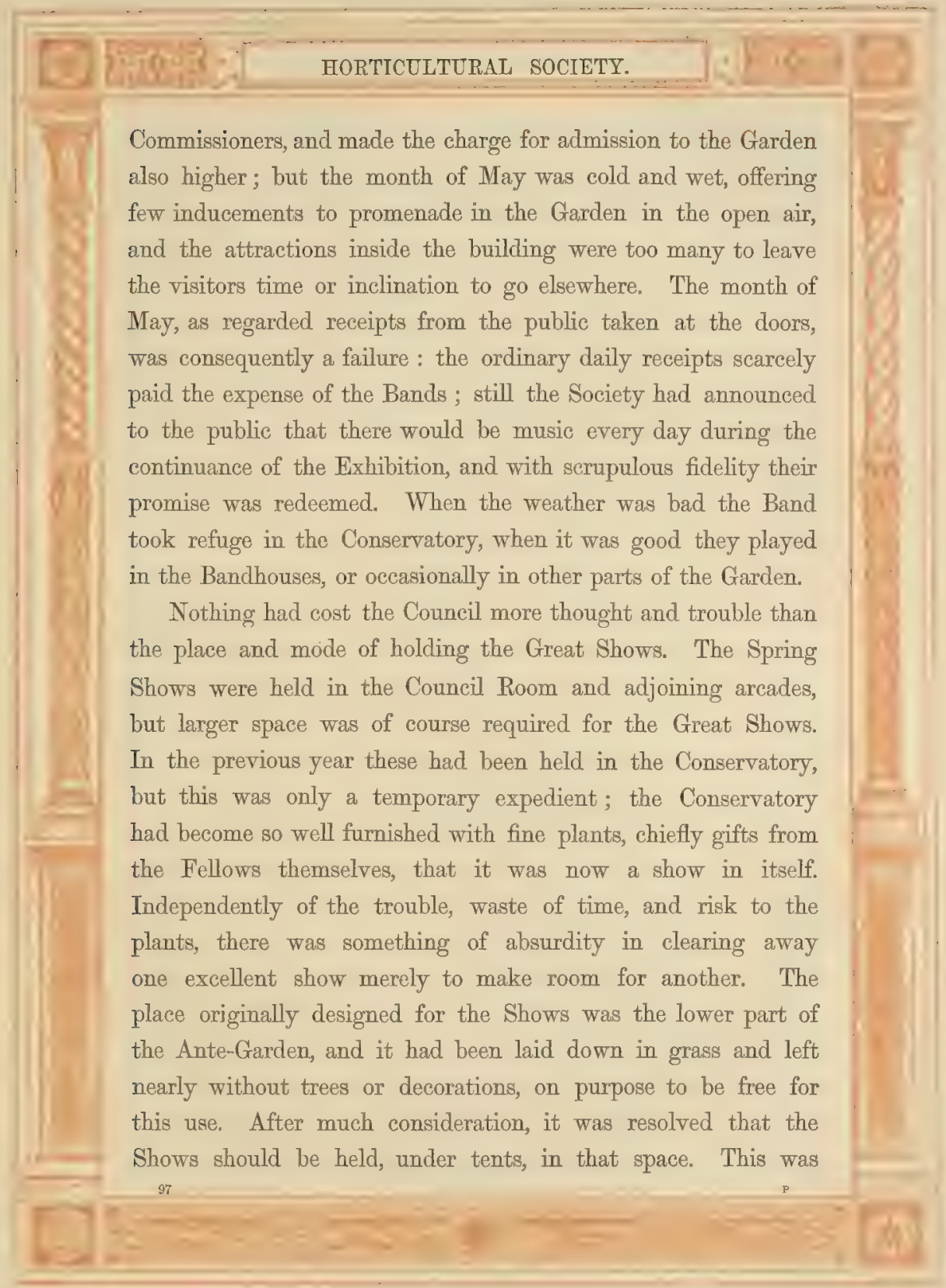




\section{THE BOOK OF THE ROYAL}

accordingly now prepared-on the west side for the American Show (which was to open on the 1st of June), and on the east side for the regular Shows of the Society. The ground was lowered in the centre of these spots, and prepared for their respective purposes: beds of peat-earth were put into the one for growing Kalmias and Rhododendrons, and grassy banks were made to serve as stages for plants in the other. Two enormous tents, of such lofty and airy proportions as would rival that of the fairy Pari-Banou, were provided, and by much exertion were erected in time for the Shows.

On the 21st of May the first Great Show was held, and, notwithstanding that the weather was indifferent, its success was complete. There are Fellows of the Society still living who remember the first small attempts at holding Flower Shows,who have watched their rise and progress until they have reached their present magnificence, and have been present at all the greatest, either in Britain or on the Continent. Such of these as were present at the Show on the 21st of May, 1862, emphatically expressed their opinion that as a show it was the finest they had ever seen. The tent was constructed without subdivisions, so that it allowed its whole extent to be seen in one view without interruption, and diffused such a subdued light as showed the flowers to the best advantage, it seeming to be accepted as an axiom by Horticulturists, that flowers never show to such advantage as under canvas. Those who saw this Show, therefore, may congratulate themselves on having seen the finest example of a Flower Show which has ever been held, or probably ever will be held. As often happens, so in this instance did vaulting ambition o'erleap itself; the 


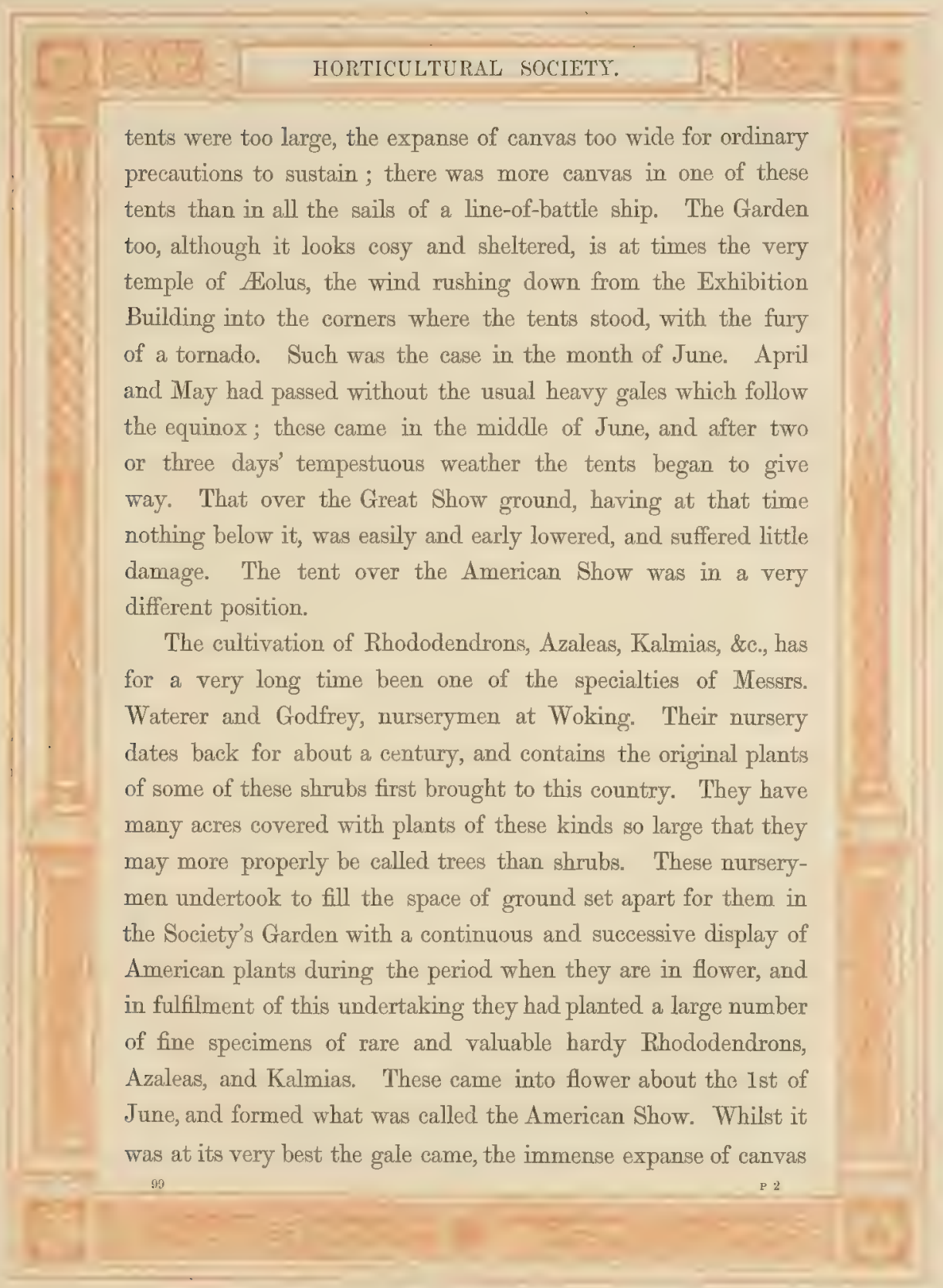




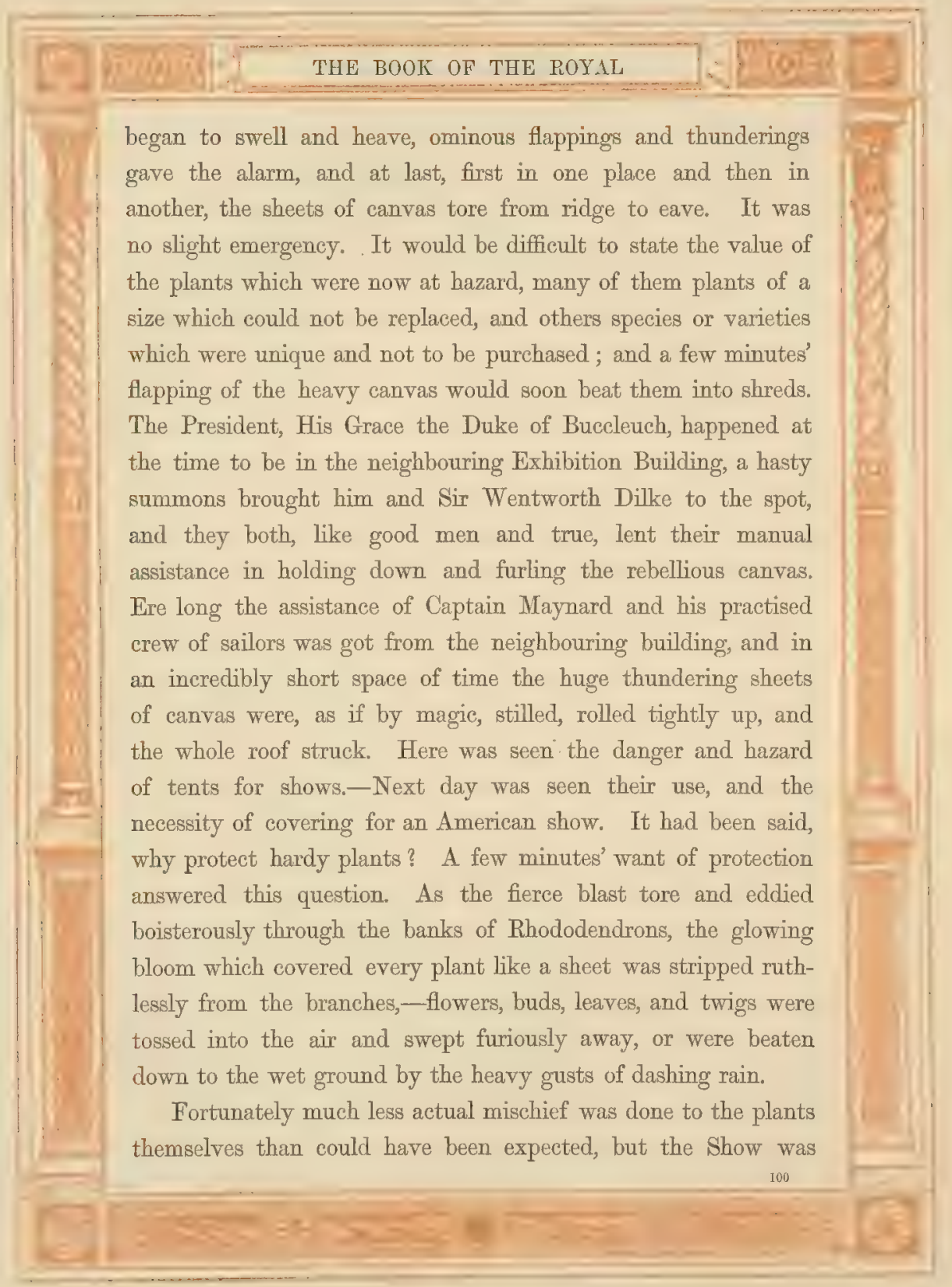




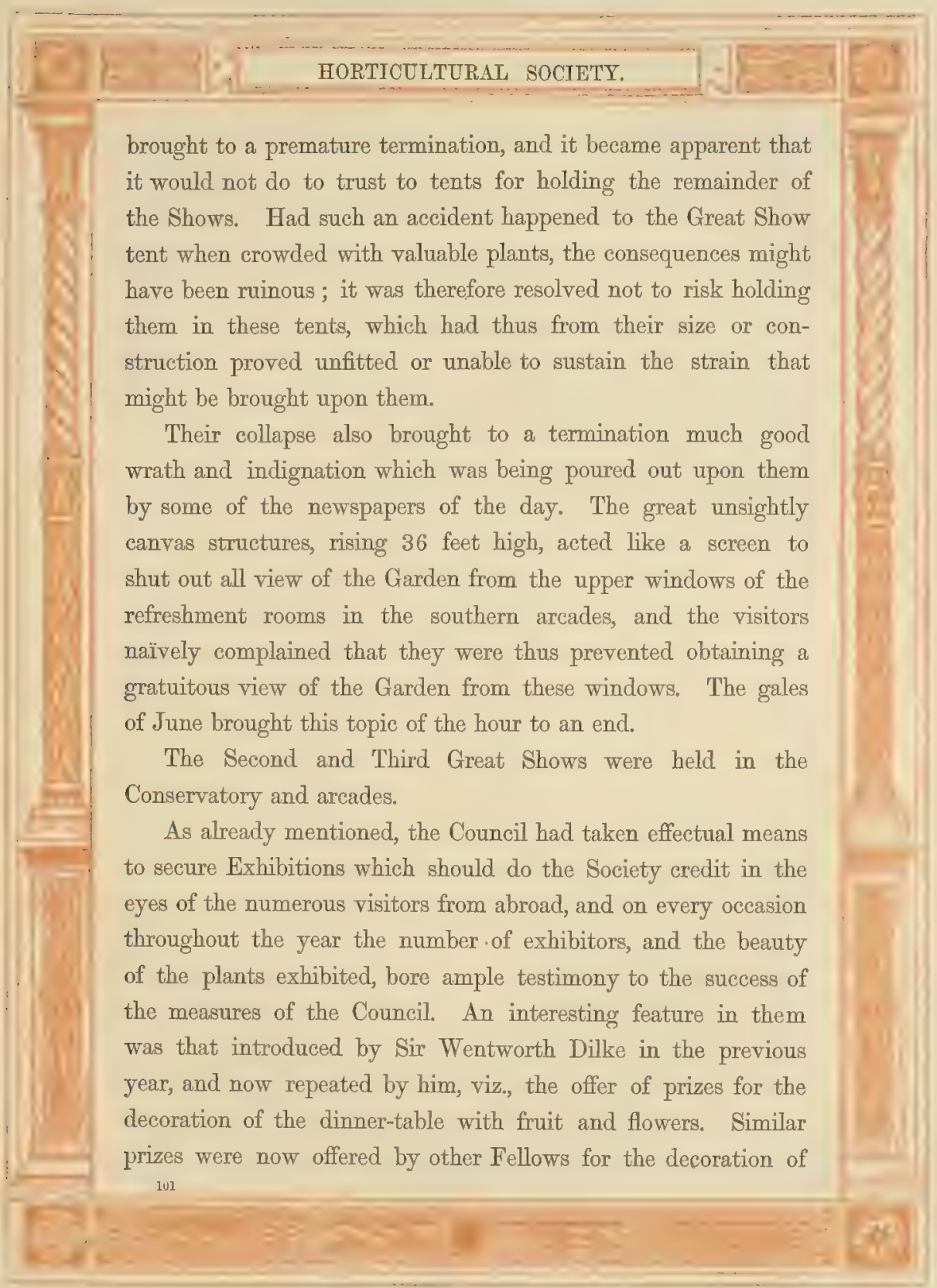


the drawing-room ; and the competition for these prizes excited a great deal of interest. At the second Great Show, when Sir Wentworth Dilke's prizes for dinner-table decoration were competed for, there were forty-six Exhibitors, each showing three vases or other vessels filled with flowers and fruit (many of the vessels being of magnificent plate, in themselves worthy of a prize), and the public took so much interest in the competition that it was difficult to get near the tables to see the articles exhibited.

The Great Shows in June and July gave large returns, but the promenades in the month of June (although at the cheapest price) were still unproductive, and it was not until after the 11th of July that a favourable change took place. That day, however, presented a combination of circumstances, of which the Council successfully availed themselves to improve the position of matters.

The Commissioners of 1862 had applied to them for permission to hold their great ceremonial, on the occasion of announcing the awards of their Juries, in the Society's Garden on the 11th of July. This the Council readily granted. It does not fall within the scope of this work to give an account of the proceedings on that day. That properly belongs to the history of the Exhibition. The Society's share in it was limited to the loan of the Garden for the day to the Commissioners, under reservation of the rights of their own Fellows. This stipulation secured to them the right to be present at the whole of the ceremonial, whether in the Exhibition or in the Garden; the two places were merged into one for the day. A magnificent dais and throne of colossal altitude, covered with crimson velvet 
and bearing golden stars and decorations, were erected on the hase on which the Memorial of 1851 now stands, then an empty spot over the cascade. To this, steps led up on either side; and here the chief feature and most important part of the ceremonial took place. The great dignitaries of our own and foreign countries met in the Conservatory. Here a crowd of those who have earned a place in the history of their country gathered together. Here rival statesmen and politicians assembled with but one object,-Lord Palmerston and Mr. Disraeli met without difference of opinion,--the leaders in Science and Art recognised by their presence the importance of the occasion, and the special International Representatives its universal and wide-spread interest. His Highness the Pasha of Egypt, as representative of Turkey, held a little court, or impromptu levée, every one apparently being anxious to pay their homage to a mind so far in advance of his country. Advantage was taken of the opportunity to secure the signature of this enlightened ruler on one of the illuminated pages on which the autographs of distinguished Visitors or Fellows are preserved. The occasion being sudden, no page had been prepared, but he promised to sign it if it could be got ready before he left England. The page was got ready in time, but no more than time: he signed it standing on the deck of his yacht, holding the page with one hand and the pen with the other, while preparations were making to set sail. The painting and decoration of the page pleased him. It was a well-executed painting, representing the pyramids and desert of Egypt-and he asked that a copy should be made for him. This was done; but before it reached him he was no more. The presence of the 
Prince of Carignan, representing Italy; the Count of Apponyi, representing Austria; M. Thouvenel, France; and numerous other Foreign Representatives, added to the interest and splendour of the scene. From the Conservatory the procession passed down to the dais, where H.R.H. the Duke of Cambridge took his place on the throne, as Her Majesty's Representative, to receive and distribute the awards to Committees representing the Exhibitors of the United Kingdom, and to the Commissioners of the Colonies and Dependencies. Around him stood the special Representatives of Foreign Countries, who were to receive and distribute the awards to the Foreign Commissioners. At this station the ceremonies commenced, and to it, after making the tour of the Garden and the Exhibition Building, the procession returned. All that passed was distinctly visible from the greater part of the Garden; the day was magnificent, and the Garden was, for the first time since its opening, fairly filled, no less a number than 44,000 having been counted.

No pecuniary benefit accrued to the Society from this day's proceedings, but it placed them in the position of having conferred a favour for which some return might fairly be asked. The Commissioners, in kindly recompense of that accommodation, gave them thereafter gratuitously every facility for advertising their bands and shows by placards in the Exhibition Building, and what was of still more importance, accorded (on payment of a moderate fine) the privilege to visitors of re-entering the Exhibition from the Garden without repayment.

The usual cessation of visitors which takes place after the close of July, when the London world of fashion goes out of town, did not take place this year, large numbers having 


\begin{tabular}{|c|c|c|}
\hline & HORTICULTURAL SOCIETY. & \\
\hline (2) & $\begin{array}{l}\text { continued to flock into the Garden on the cheap days in August, } \\
\text { September, and October. In the latter month took place the } \\
\text { most important Show for the practical advancement of that } \\
\text { science to which the Horticultural Society is devoted :- the } \\
\text { Great International Fruit Show. It has often been observed that } \\
\text { when the time is ripe for the development of an idea, it occurs } \\
\text { simultaneously to many minds. This seems to have been the case } \\
\text { with International congresses or exhibitions of fruit in } 1862 \text {. At } \\
\text { the same time that the Horticultural Society were planning their } \\
\text { Great Exhibition of Fruit on the 8th of October, the federated } \\
\text { societies of Belgium were convening a similar congress to be } \\
\text { held at Namur in September, and an exhibition at Vienna on the } \\
\text { 4th of October was in like manner organised by the Austrians. } \\
\text { The Horticultural Society exerted itself to assist the Pomological } \\
\text { Congress at Namur, and that body in return equally contri- } \\
\text { buted to the success of the International Fruit Show at London. } \\
\text { This was the first International Horticultural Show held in this } \\
\text { country, and consequently many points which should have been } \\
\text { attended to may have been overlooked, and it may reasonably } \\
\text { be expected that the next meeting of the same kind will greatly } \\
\text { excel this Show both in beauty and in importance. But that } \\
\text { lies in the future: so far as the past is concerned only one } \\
\text { opinion prevails; the great pageant of the year was the ceremony } \\
\text { of the } 11 \text { th of July, but the great horticultural event of the year } \\
\text { was the October International Fruit Show. This reflected more } \\
\text { credit on the Society than all the rest of their undertakings } \\
\text { during the year; it had a more liberal and comprehensive object. } \\
\text { That this was thought to be the case by those best qualified to } \\
\text { judge, may be inferred from the interest taken in it and support } \\
\text { 105 }\end{array}$ & \\
\hline & & \\
\hline
\end{tabular}




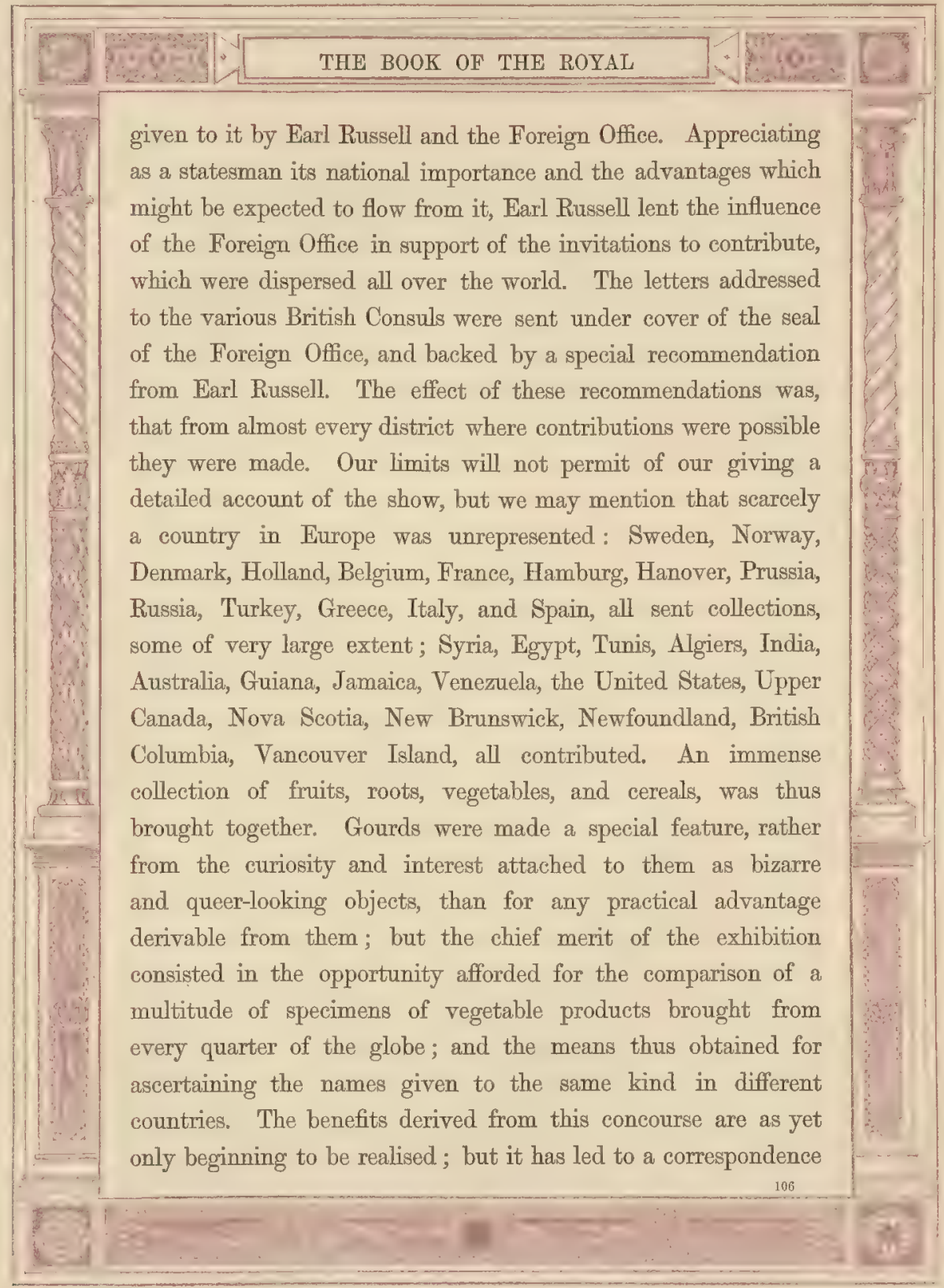




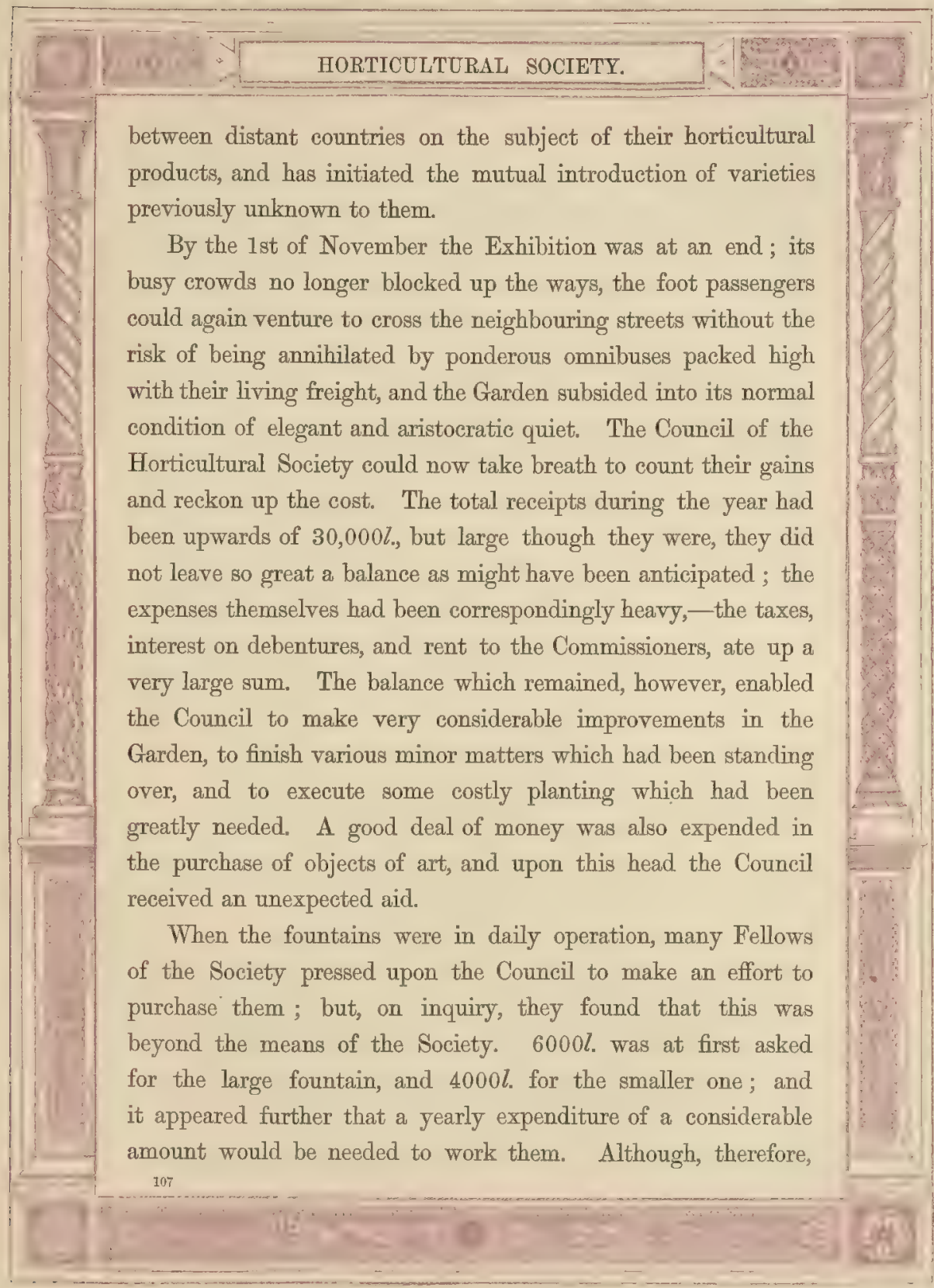




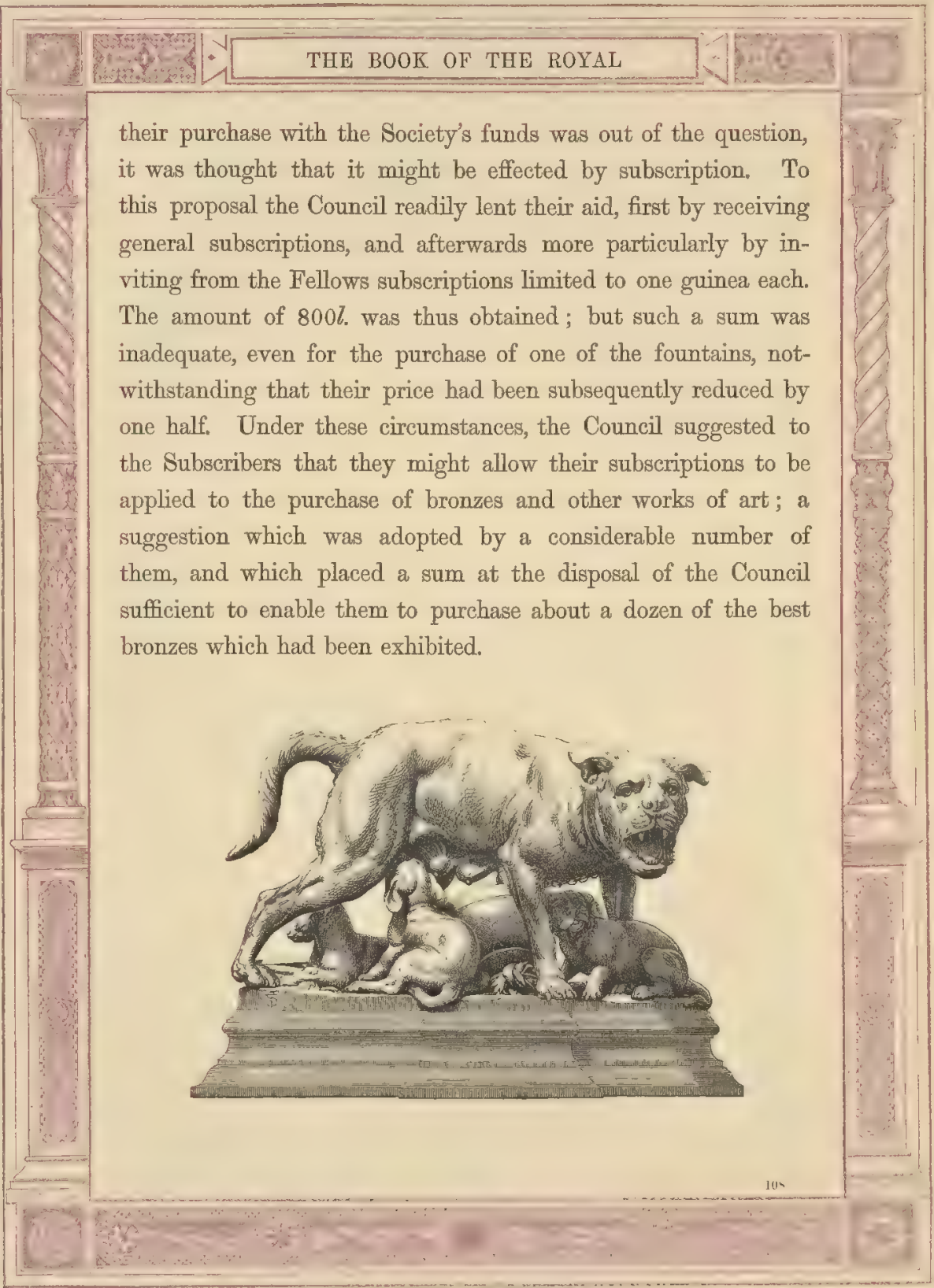


THE DESCRIPTION OF THE GARDEN, CONSERVATORY, STATUES, \&c. 


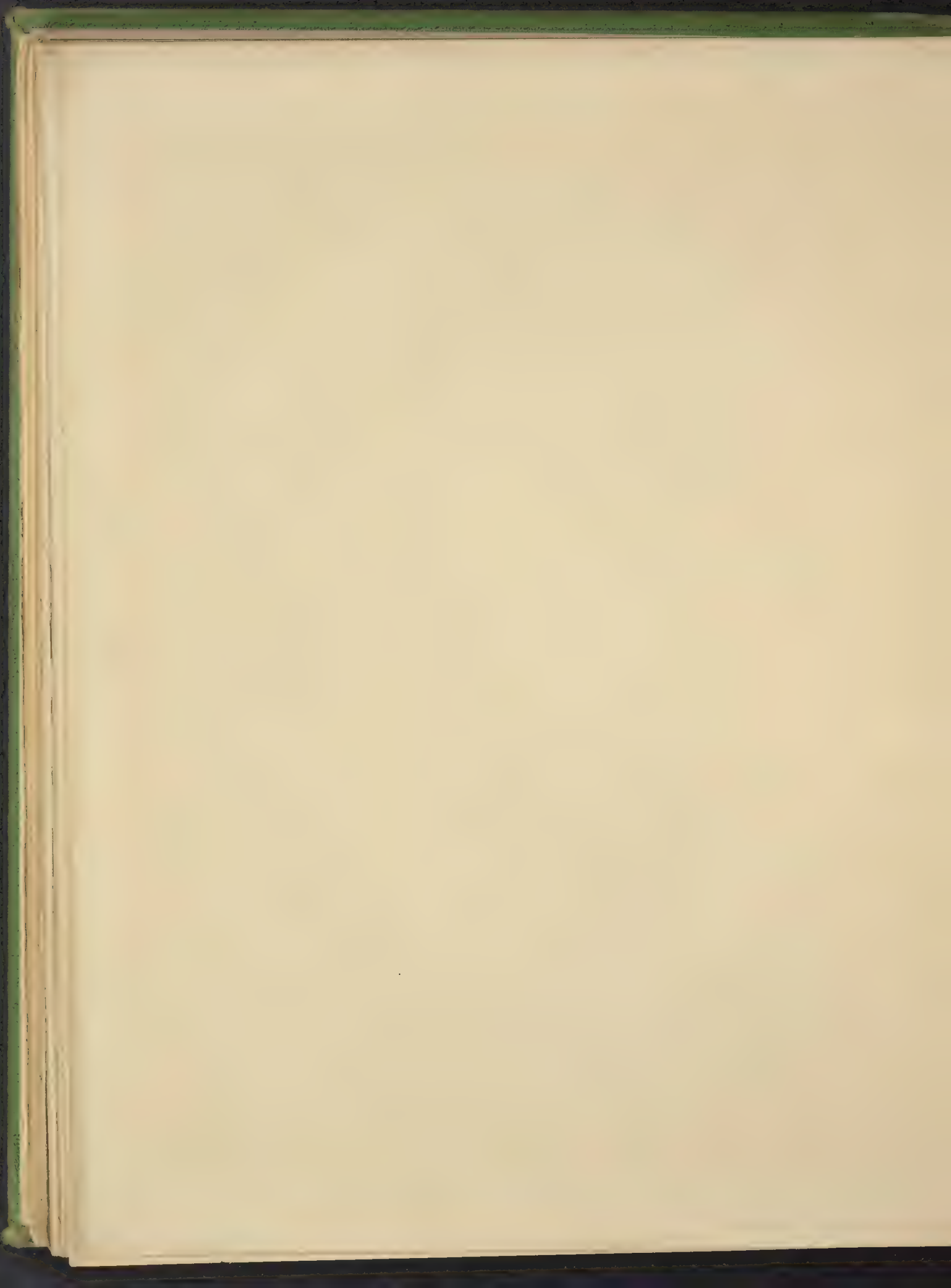




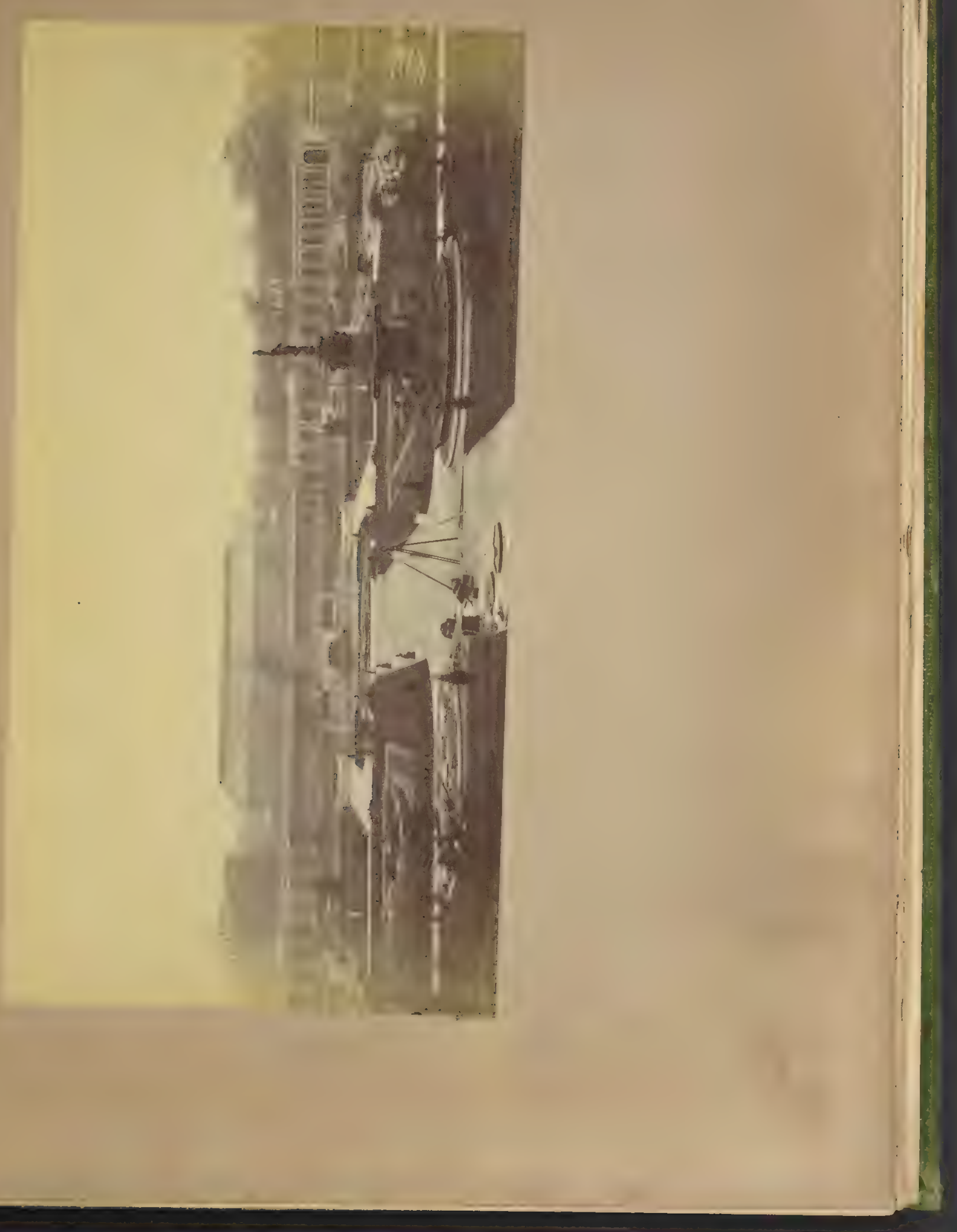





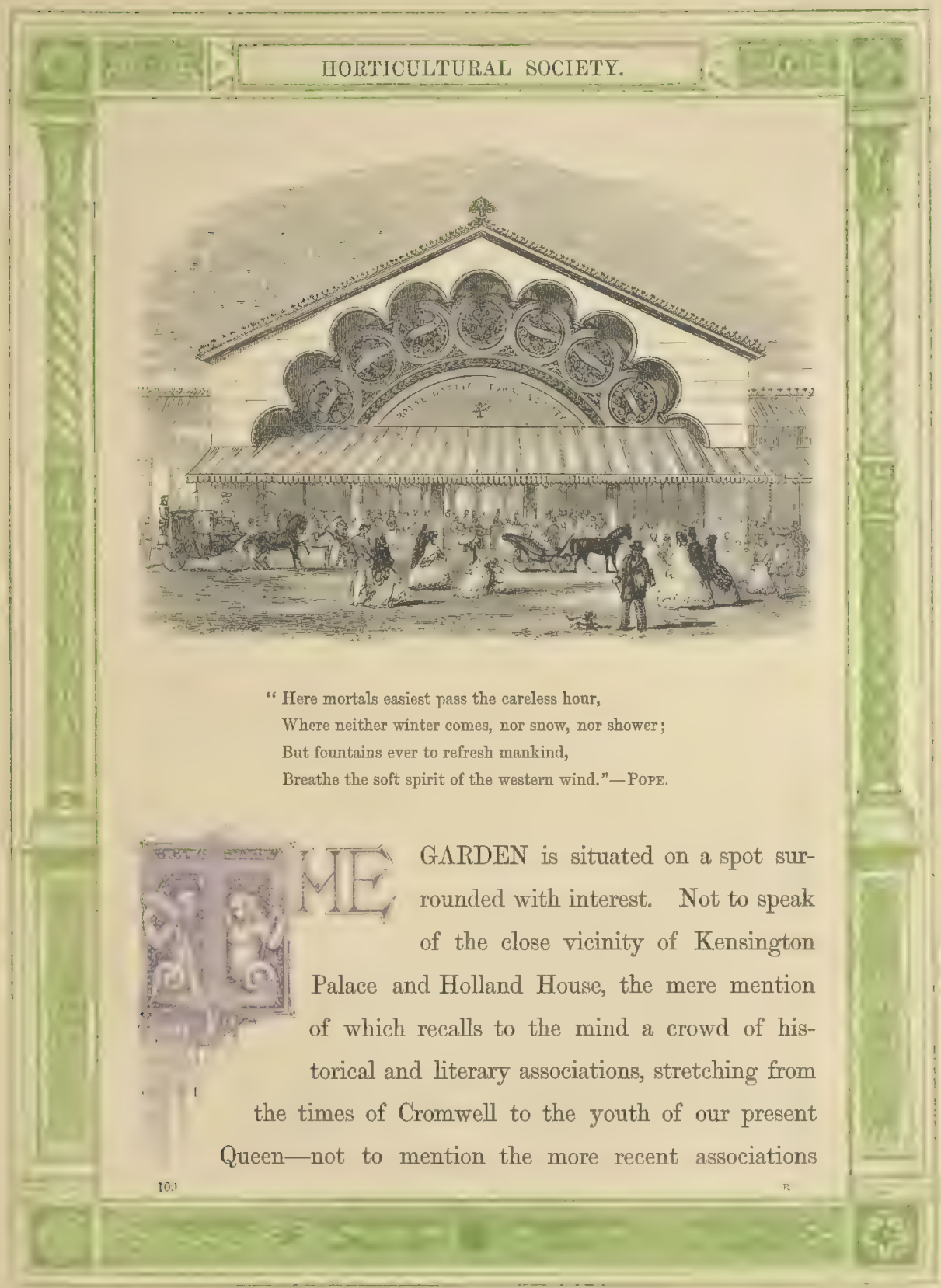




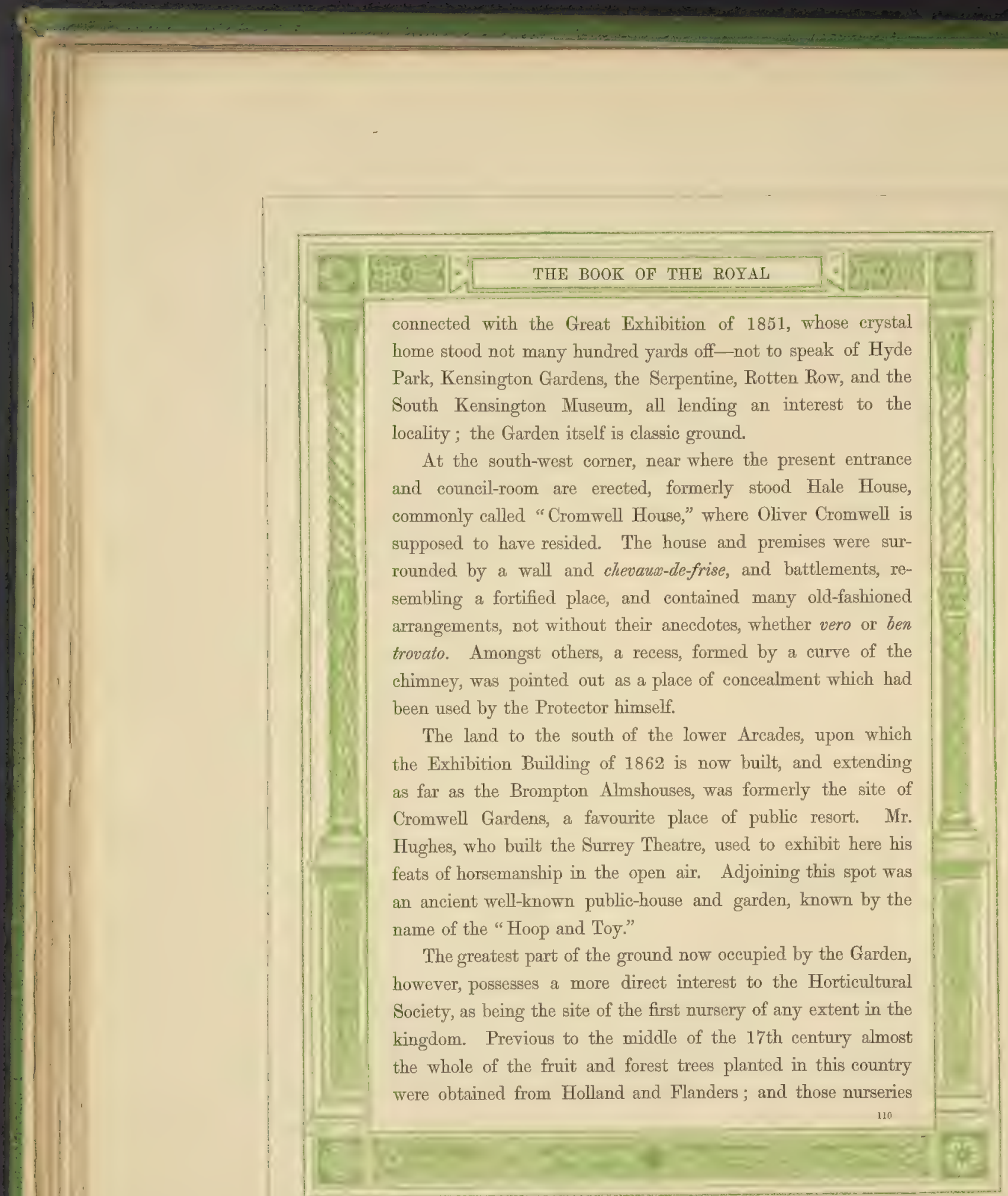




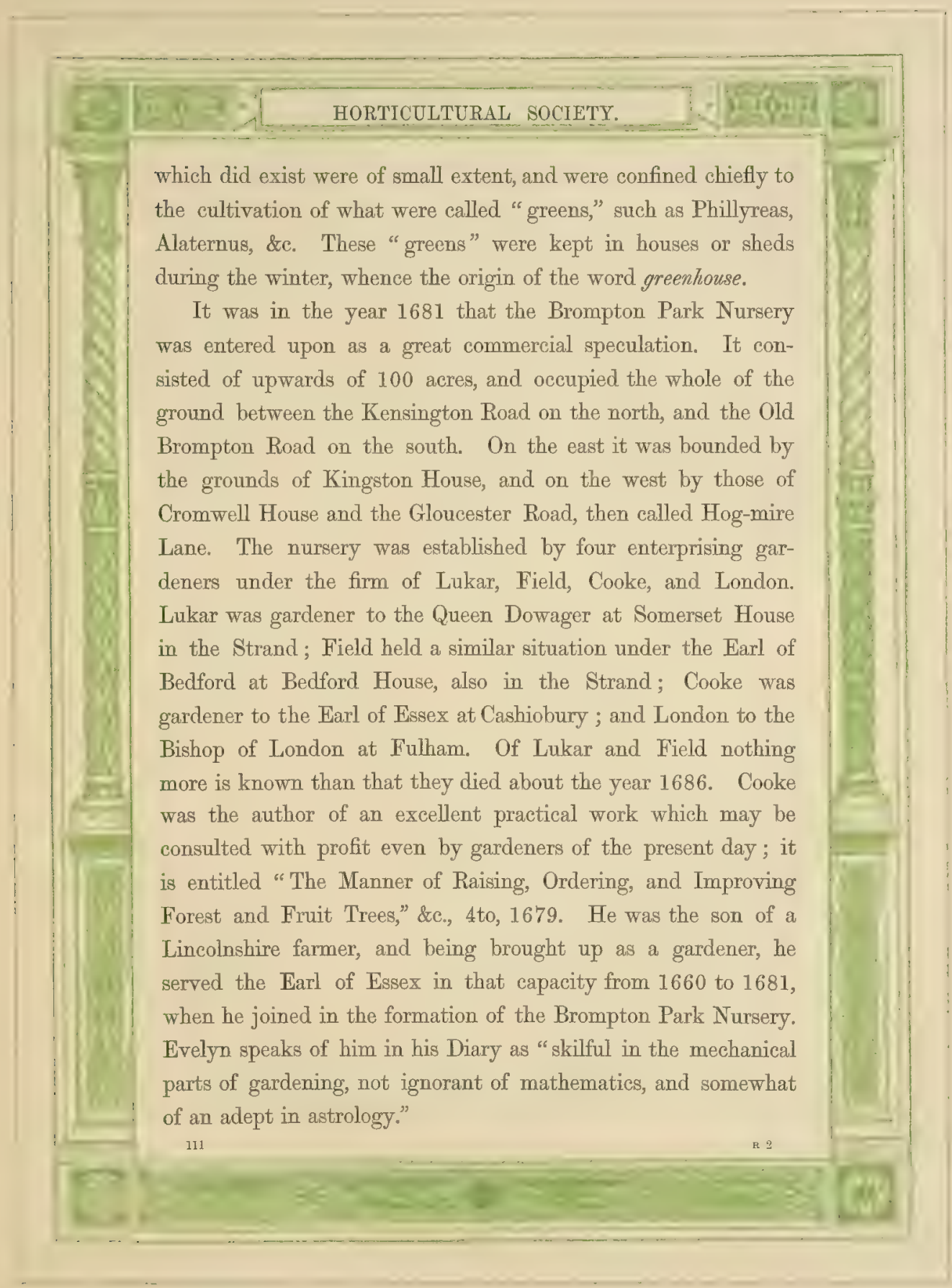




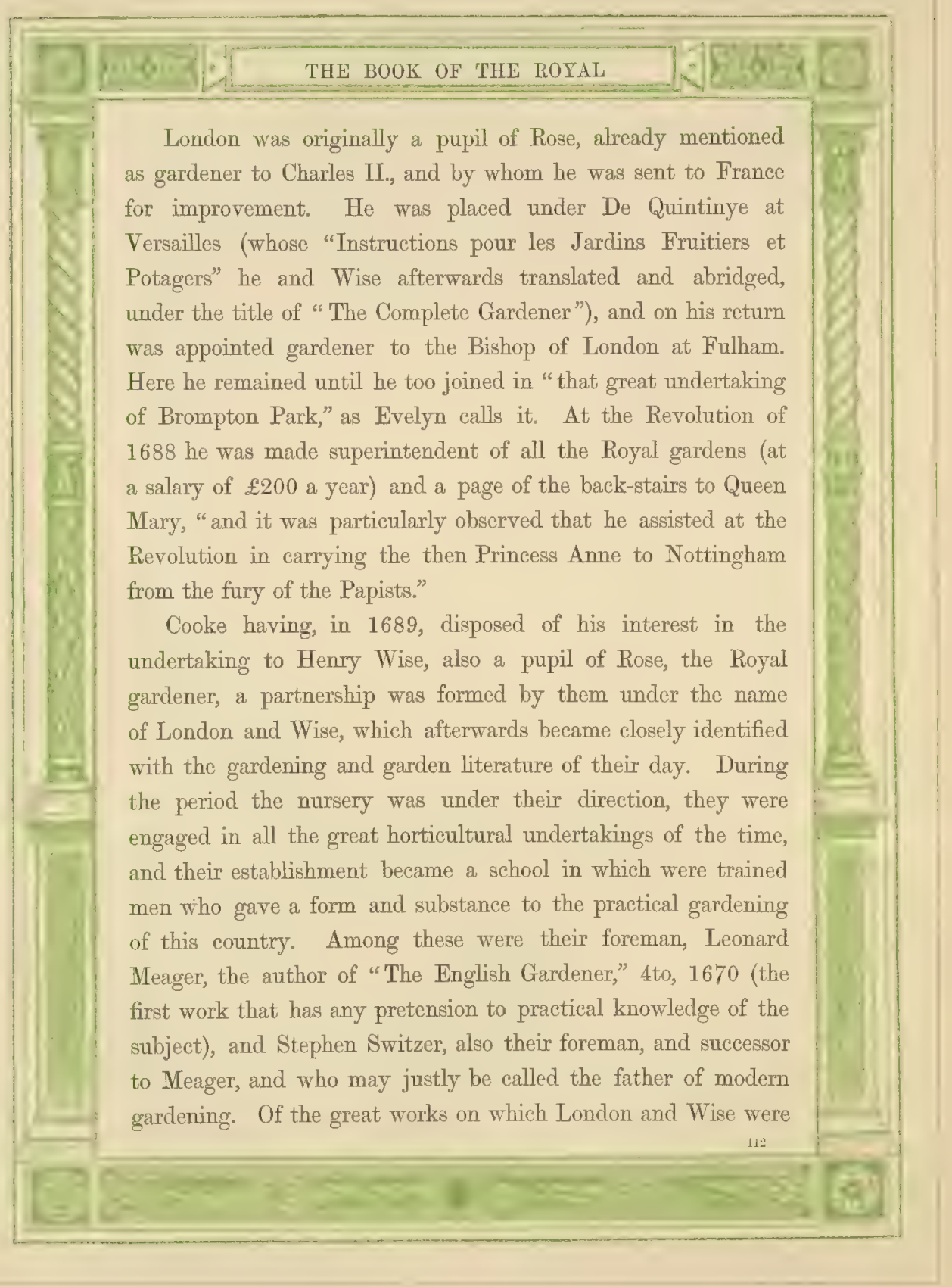




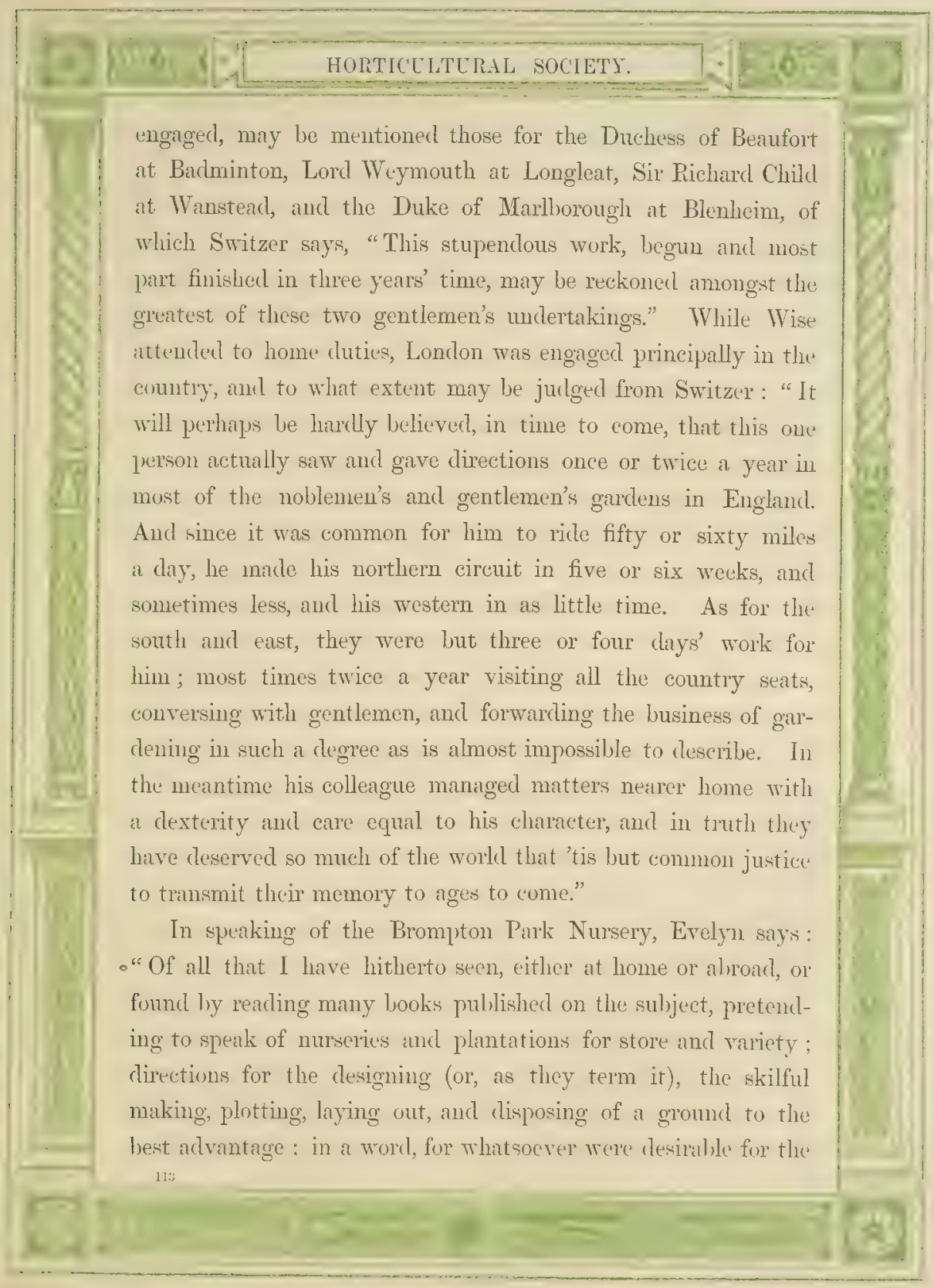


furniture of such a ground with the most excellent and warrantable fruit (I say warrantable, because it is particularly due to their honest industry, and so rarely to be met with elsewhere), and other accessories to gardens of all denominations, as in that vast, ample collection which I have lately seen and well considered at Brompton Park, near Kensington; the very sight of which alone gives an idea of something that is greater than I can well express without an enumeration of particulars ; and of the exceeding industry, method, and address of those who have undertaken and cultivated it for public use, I mean Mr. George London (chief gardener to their Majesties), and his associate Mr. Henry Wise.

"As for the nursery part, in voucher, and to make good what J have said on that particular, one needs no more than to take a walk to Brompton Park (upon a fair morning) to behold and admire what a magazine these industrious men have provided fit for age and choice in their several classes, and all within one enclosure; such an assemblage I believe as is nowhere else to be met with in this kingdom, nor in any other that I know of."

In 1714 the nursery passed into the possession of Smith and Carpenter; the latter of whom was author of an edition of the "Retired Gardener," a work which was originally a translation by London and Wise of Liger's "Jardinier Solitaire." It then passed into the hands of a succession of nurserymen, the chief of whom were Gray and Wear, by some members of whose families, or partners, it was held from 1756 to 1852 , when it was in the hands of John Adams, the successor of Gray, Adams, and Hogg. Various portions of the grounds had been disposed of, from time to time, as the suburban residences became general in the 


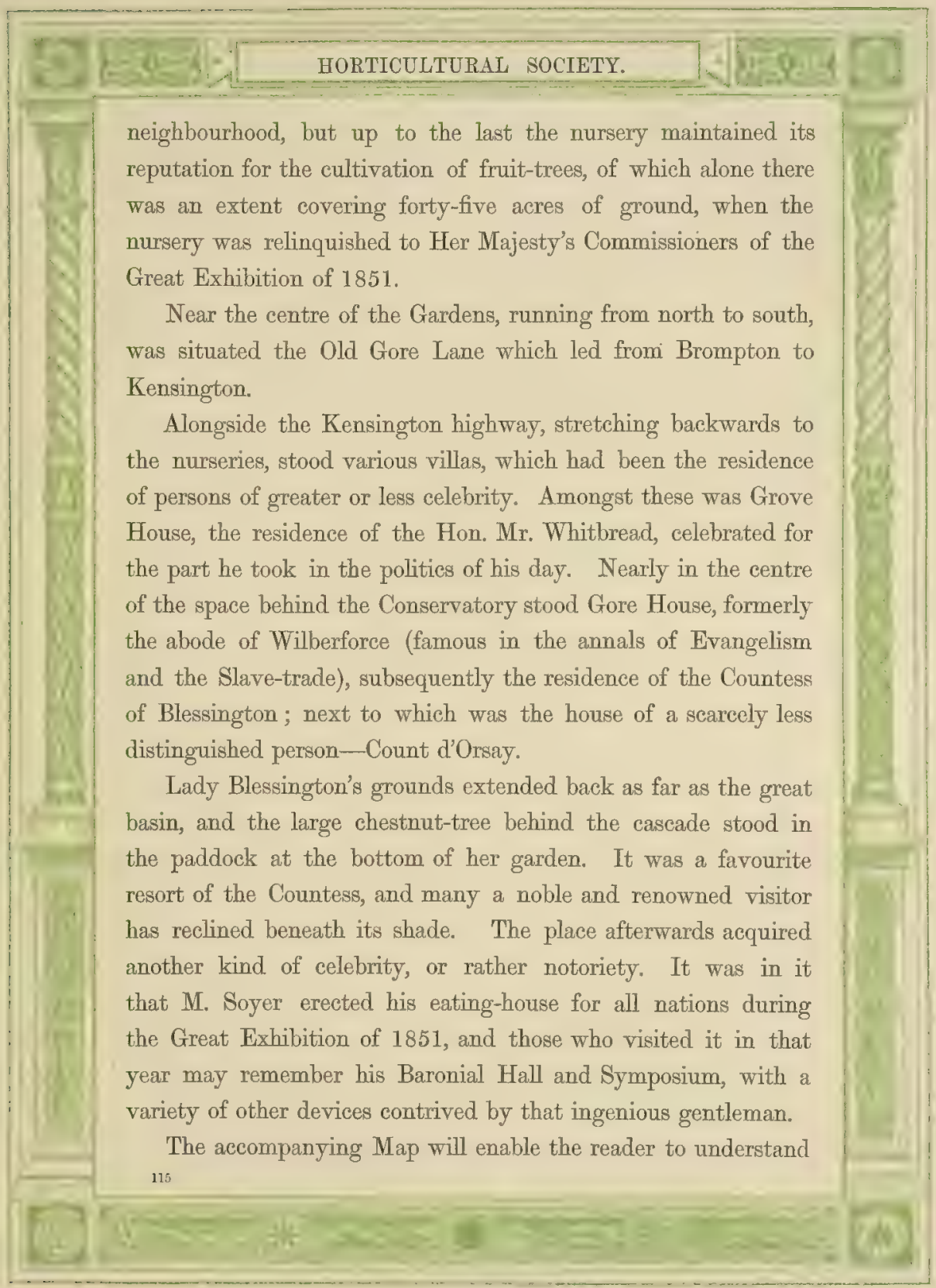




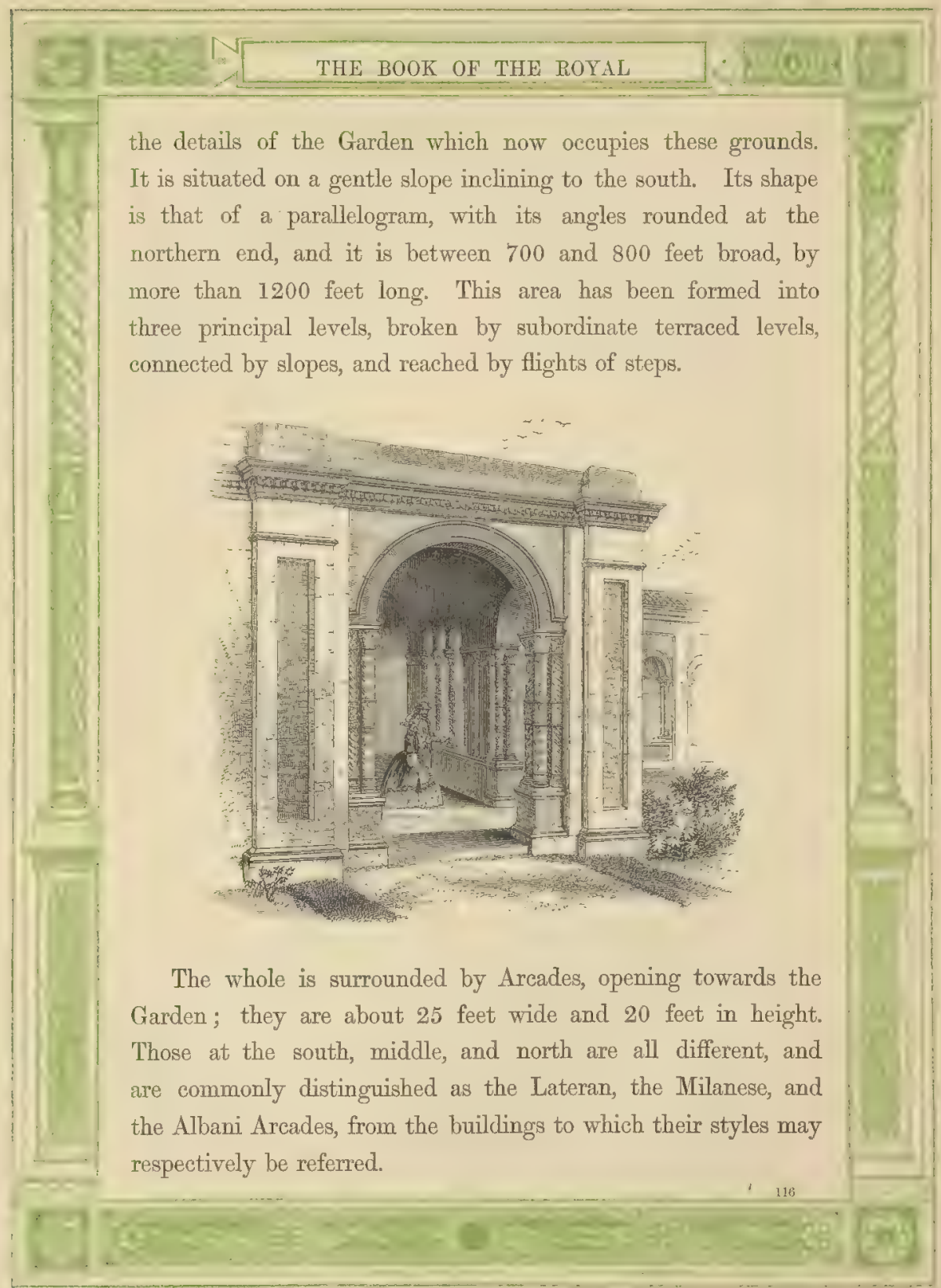




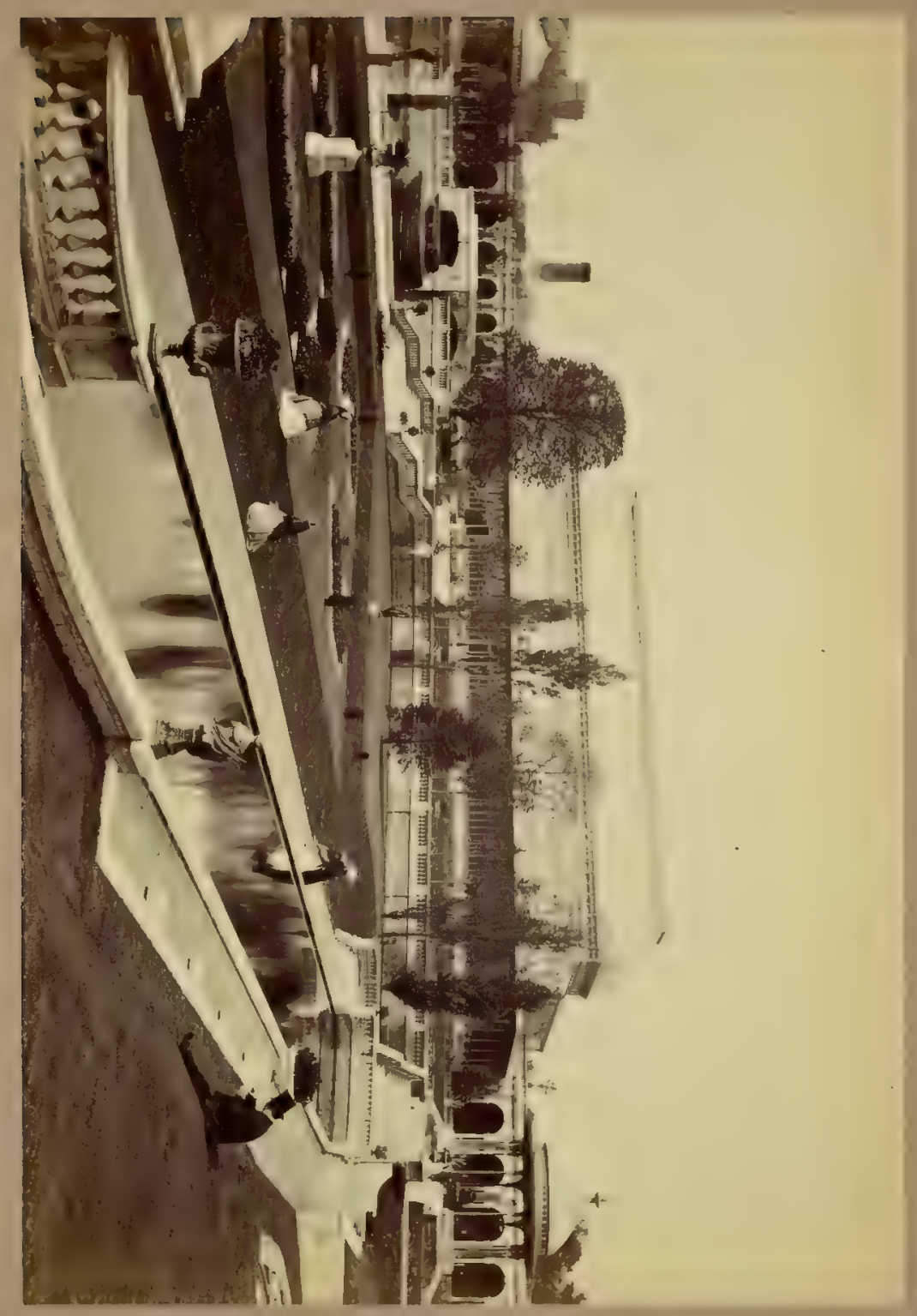



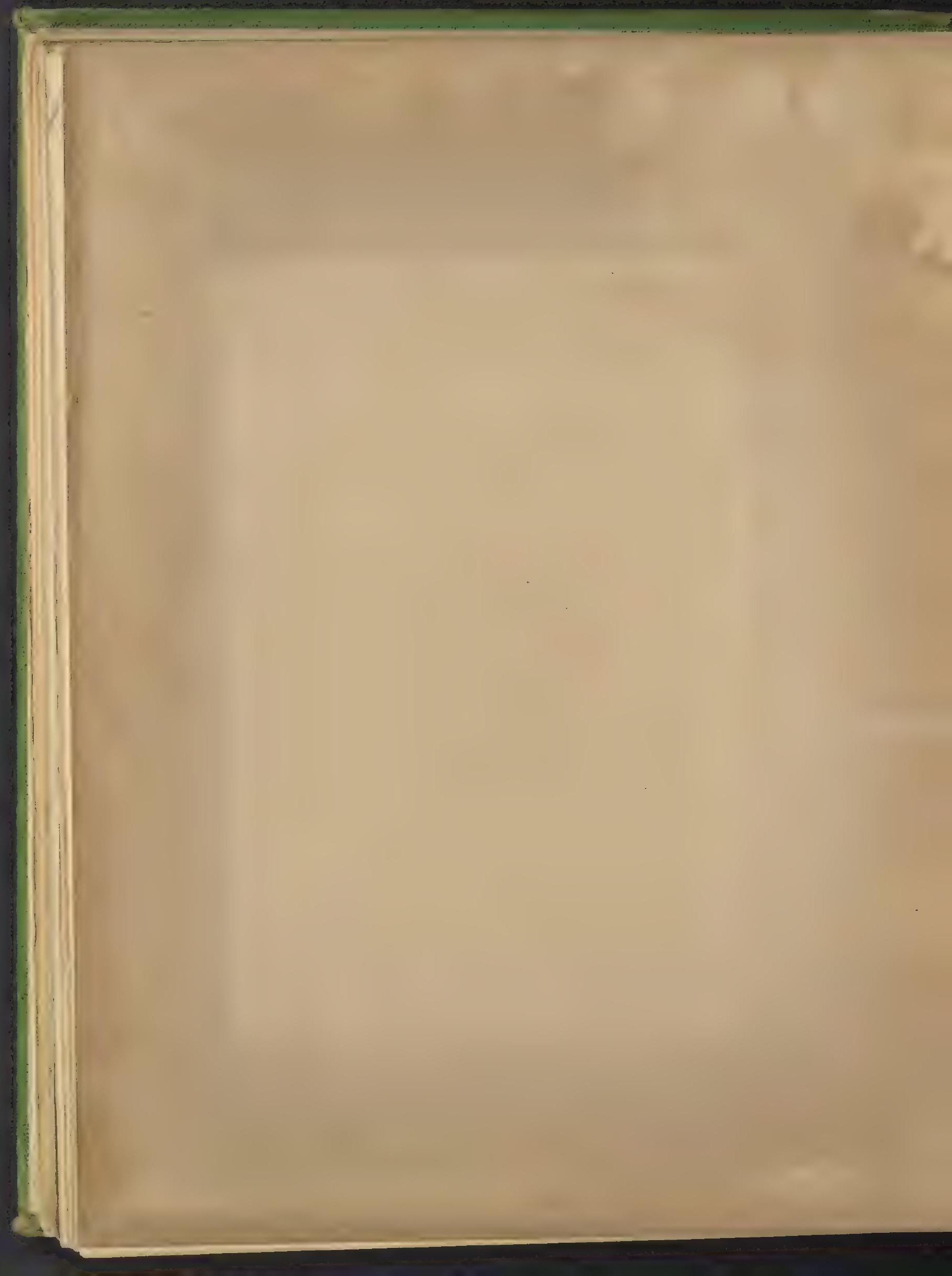


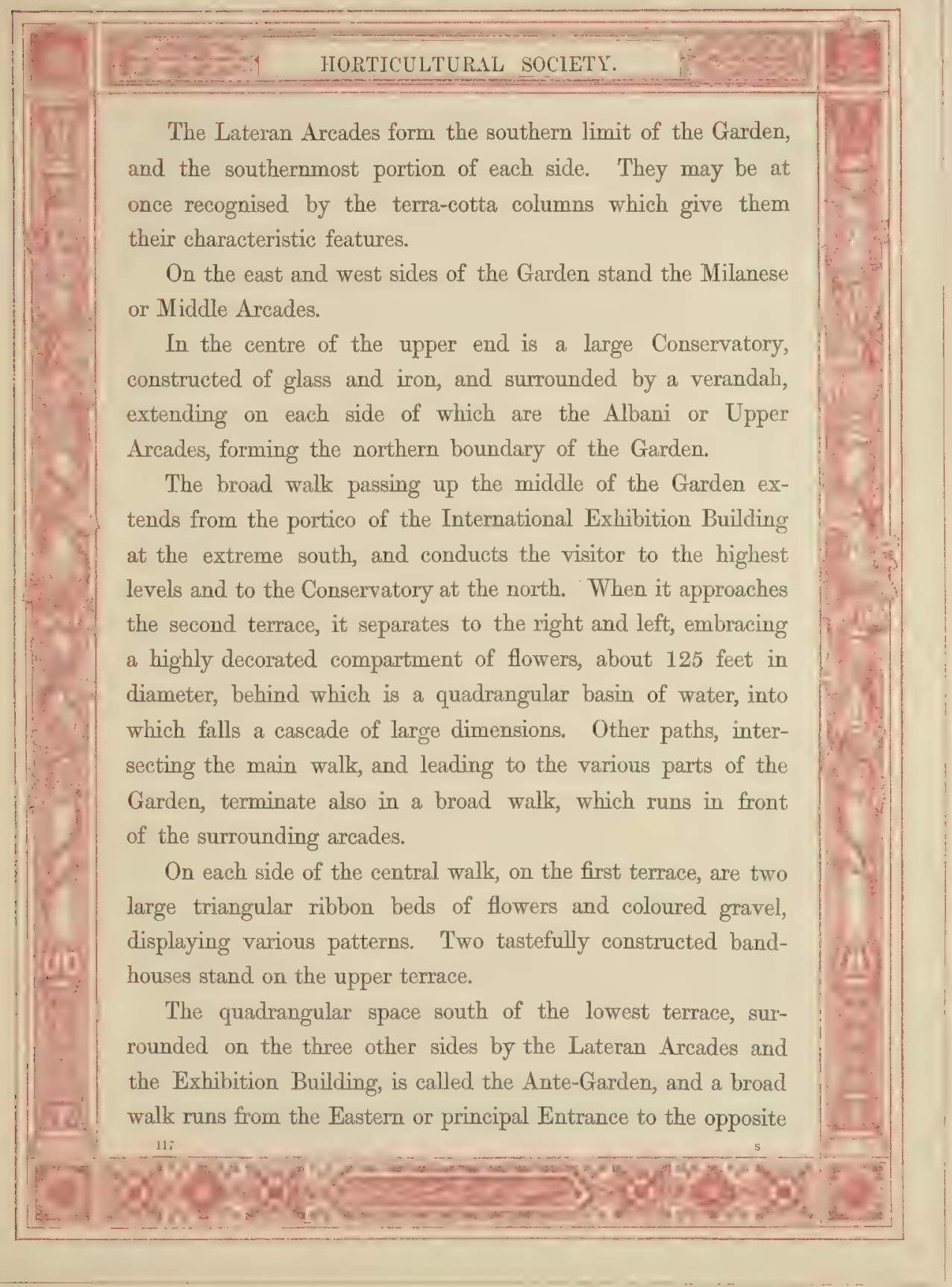




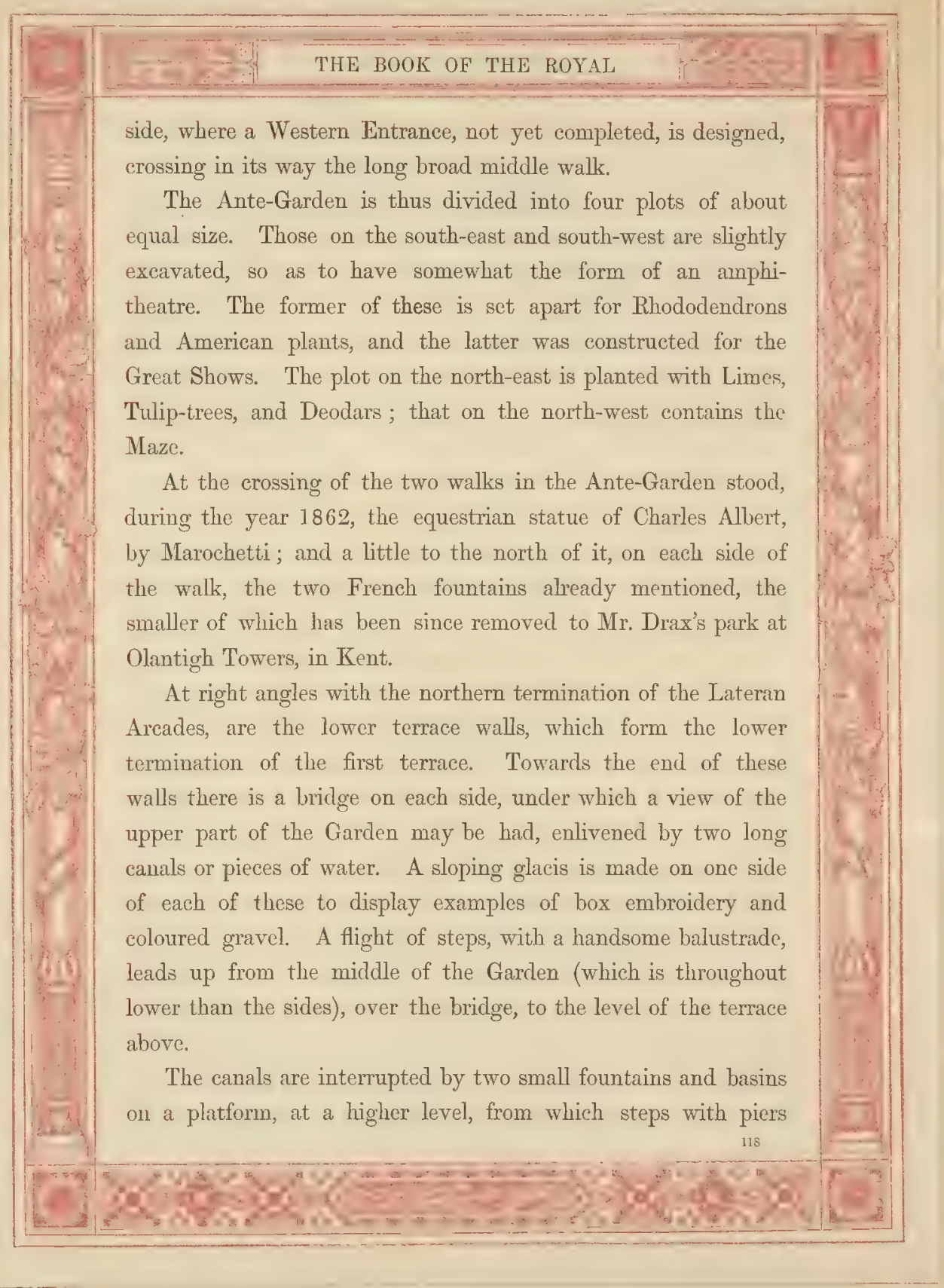




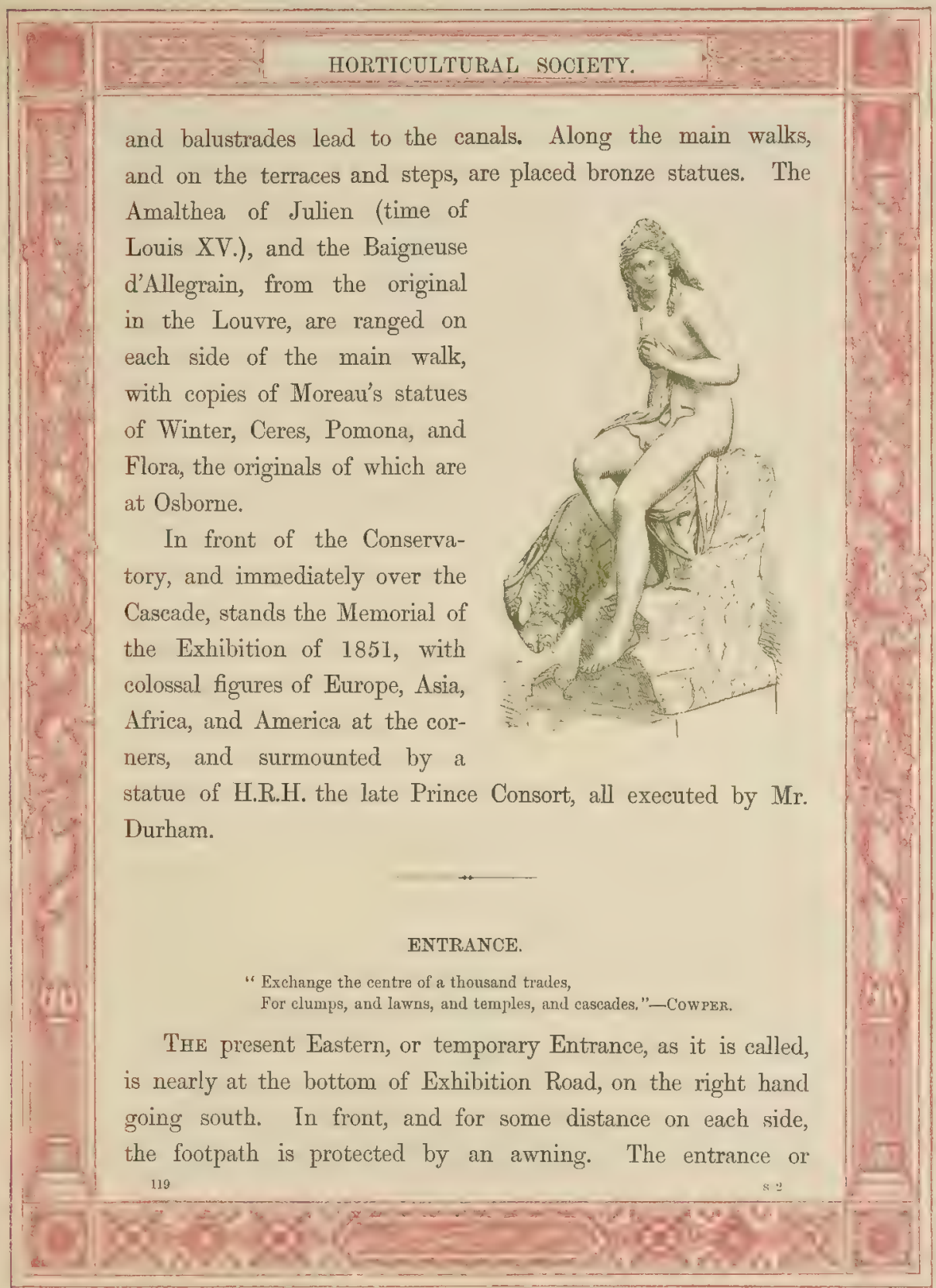




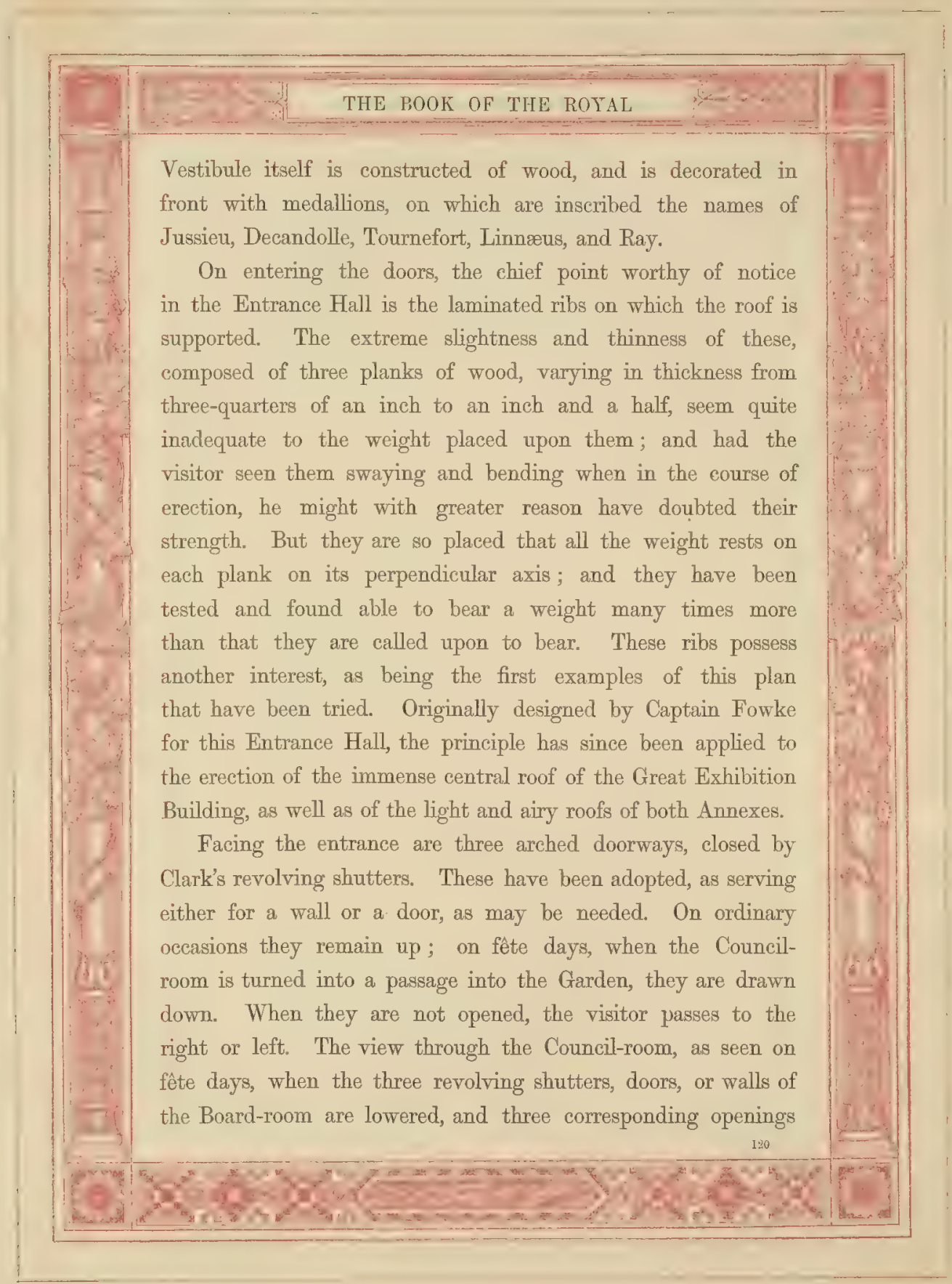




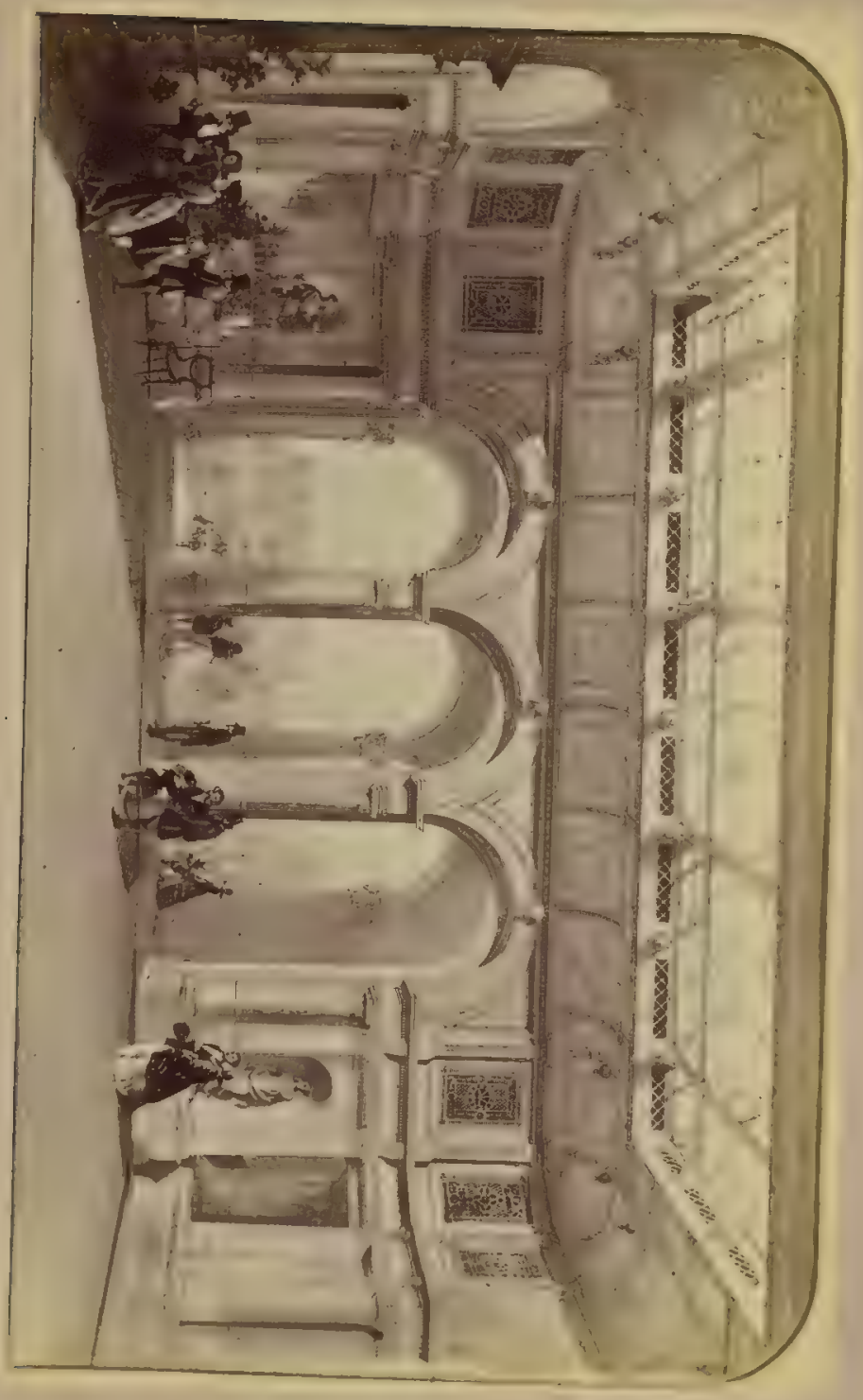



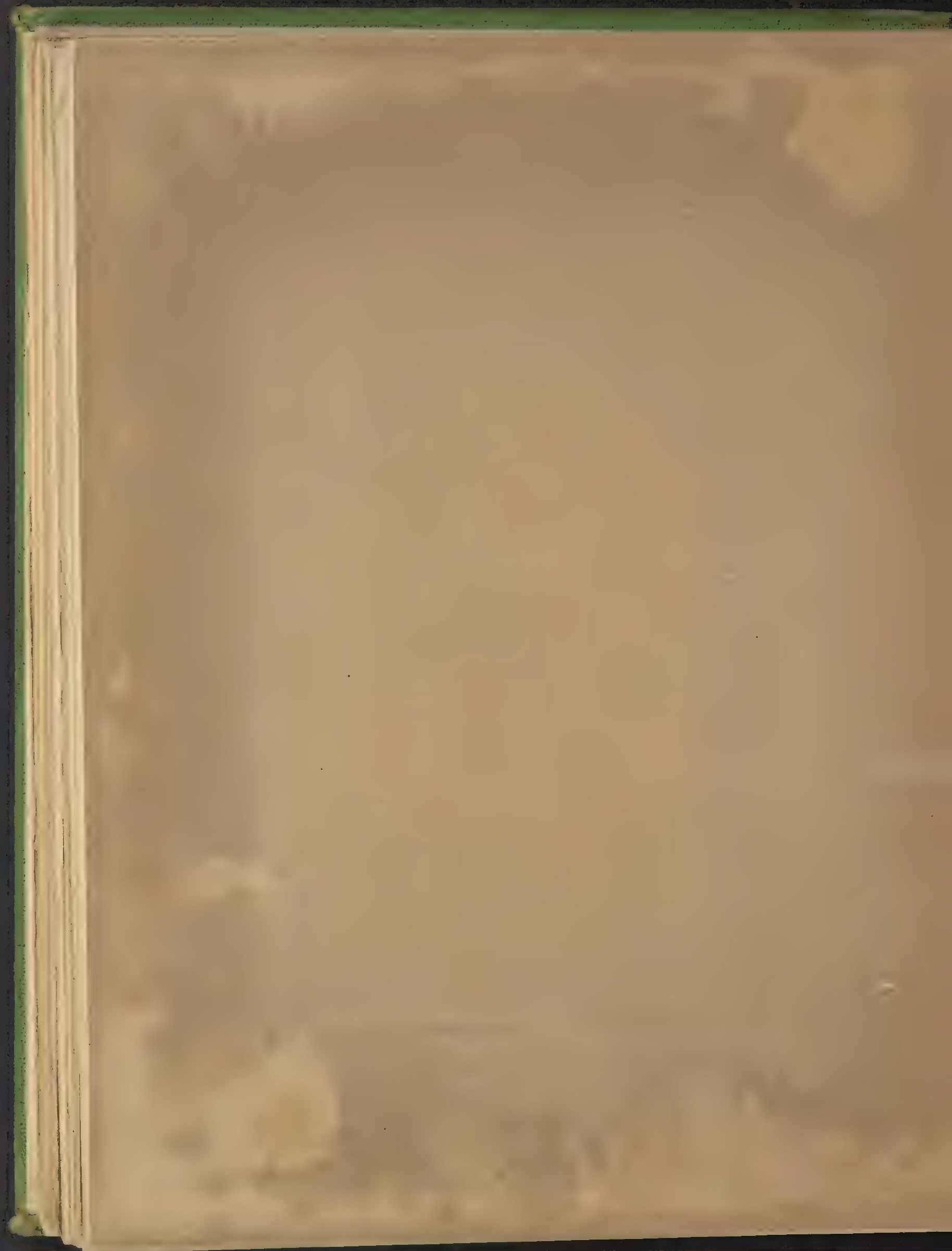


\begin{tabular}{|c|c|}
\hline & IL HORTICULTURAL SOCIETY. II \\
\hline$\frac{1}{31}$ & $\begin{array}{l}\text { on the opposite side of the Council-room are in like manner } \\
\text { opened, is shown in the accompanying photograph, } \\
\text { The Council-room was designed by Capt. Fowke. It is } \\
\text { entered (except when the large shutters are opened) from the } \\
\text { passage on the right, after passing through the Vestibule or } \\
\text { Entrance Hall. It is } 60 \text { feet long by } 40 \text { feet wide, and } 30 \text { feet } \\
\text { high; a portion of this space, however, is occupied by architec- } \\
\text { tural details. Its sides are formed by columns and pilasters of } \\
\text { Roman Doric, surmounted by a cornice, from which semicircular } \\
\text { arches take their source. Three of these arches, on the east and } \\
\text { west sides respectively, furnish the openings already mentioned, } \\
\text { which are used as entrances when required, forming a passage } \\
\text { into the Garden through the colonnades; a fourth arch occupies } \\
\text { the centre of the north end, and another the south. The four } \\
\text { angles are cut off and fitted with large mirrors, on each side } \\
\text { of which are niches for statues; and above, in each corner, are } \\
\text { three window-like openings, left to aid in ventilation, and fitted } \\
\text { with ornamental iron castings. The ceiling consists of horizontal } \\
\text { lights of ground glass, through which gas pendants descend. The } \\
\text { floor is paved with Minton's encaustic tiles, and the heating is } \\
\text { effected by hot-water pipes, which are carried beneath the floor } \\
\text { in channels covered with ornamental gratings. } \\
\text { Standing on easels are some frames, containing illuminated } \\
\text { pages bearing the signatures of various Royal personages who } \\
\text { have been Fellows of the Society, or have visited its Garden. } \\
\text { The illuminated paintings, for the most part, consist of fruits } \\
\text { and flowers, bearing some allusion to the person whose signature } \\
\text { they surround-or are used to suggest some sentiment, such as } \\
\text { those which the Italians call concetti. The illustration on the } \\
\text { 121 }\end{array}$ \\
\hline & \\
\hline
\end{tabular}




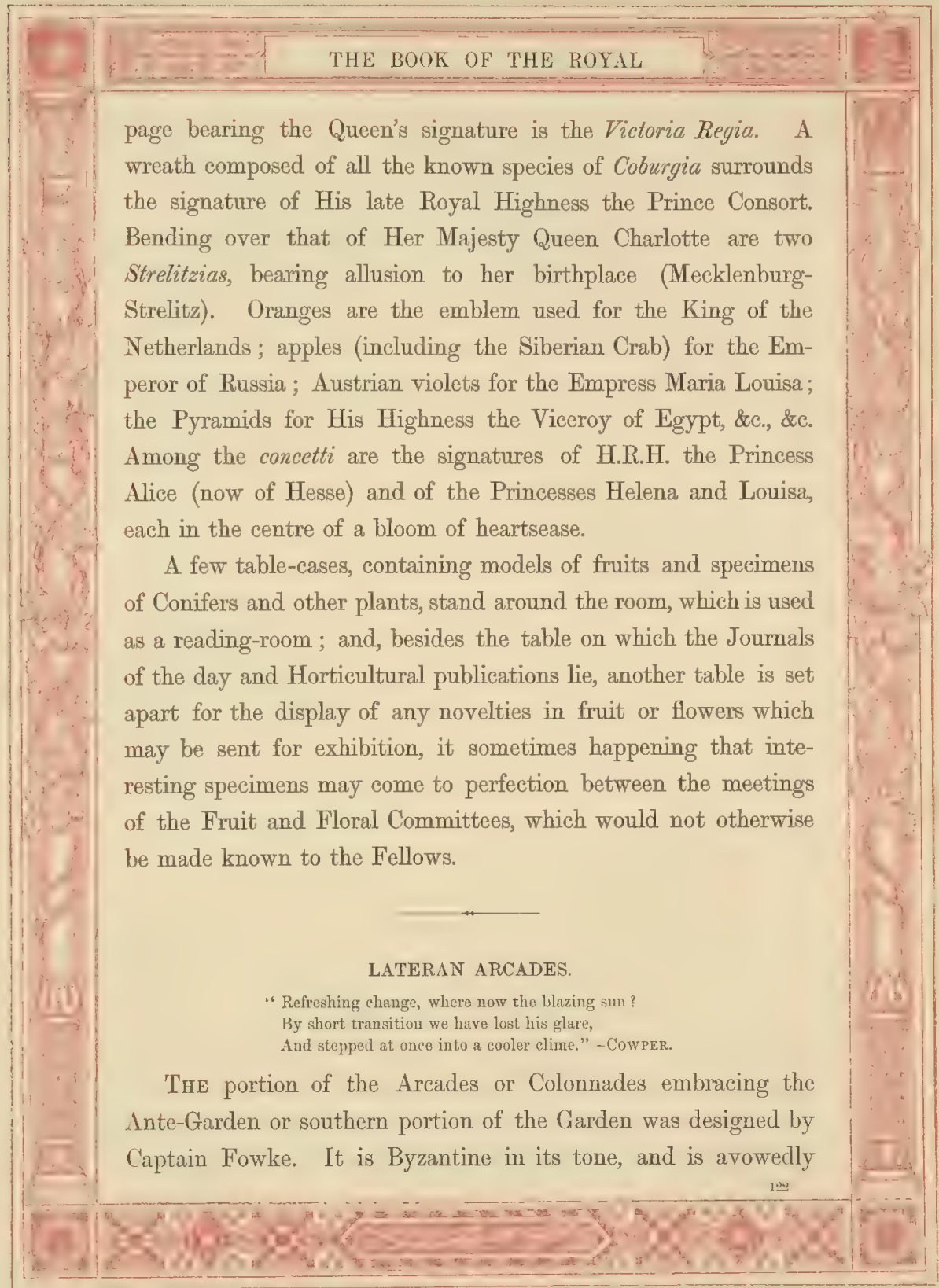




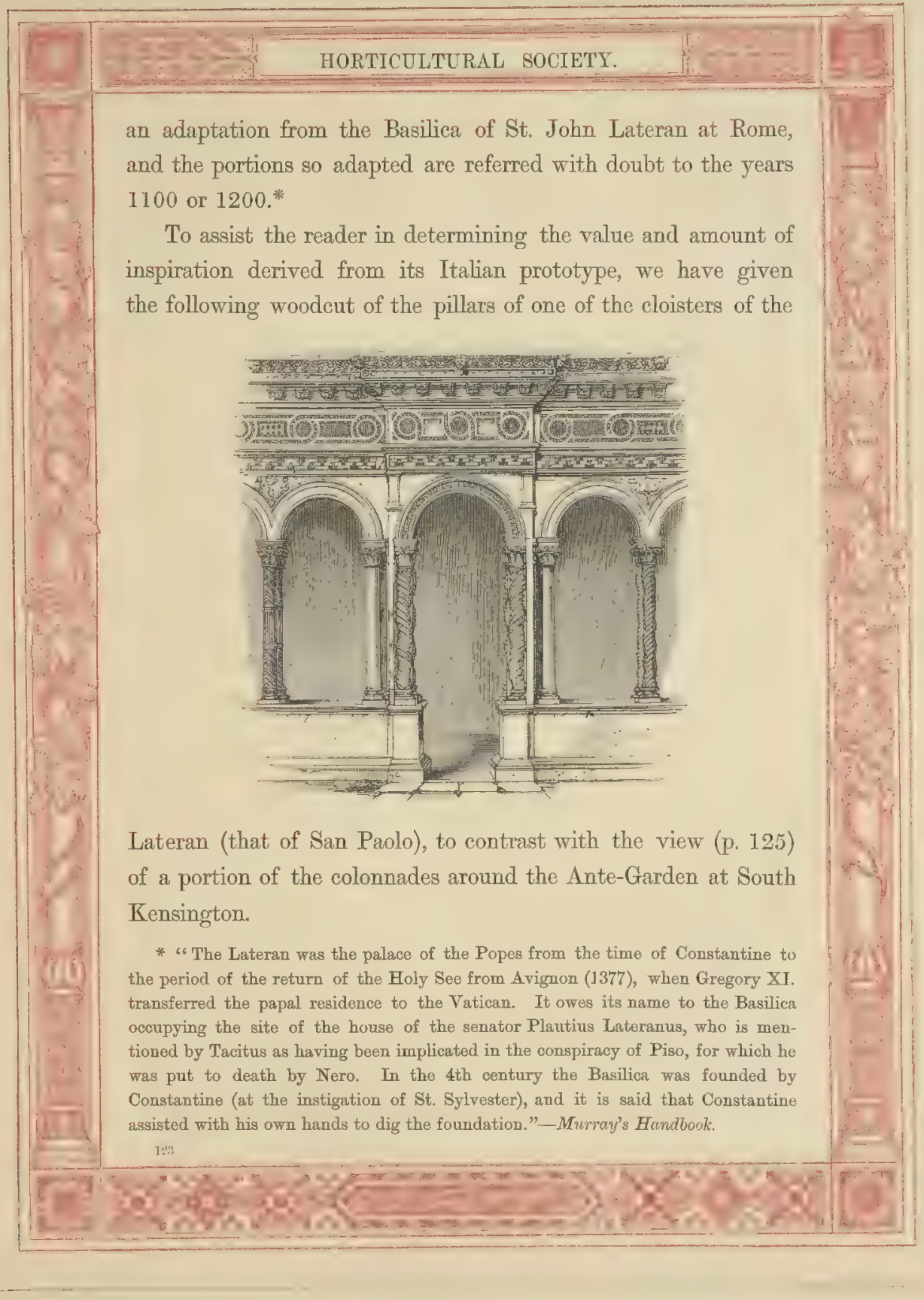




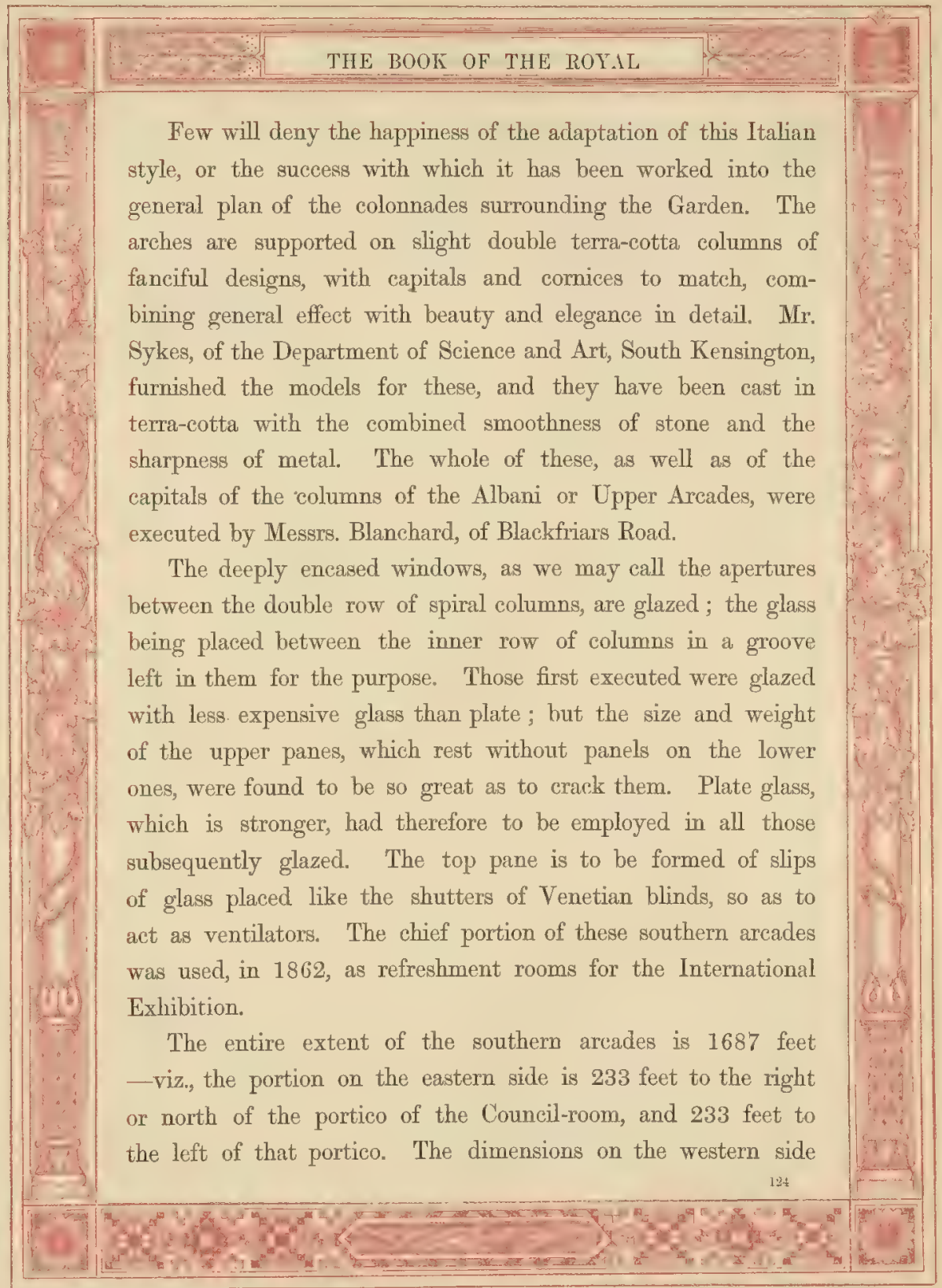




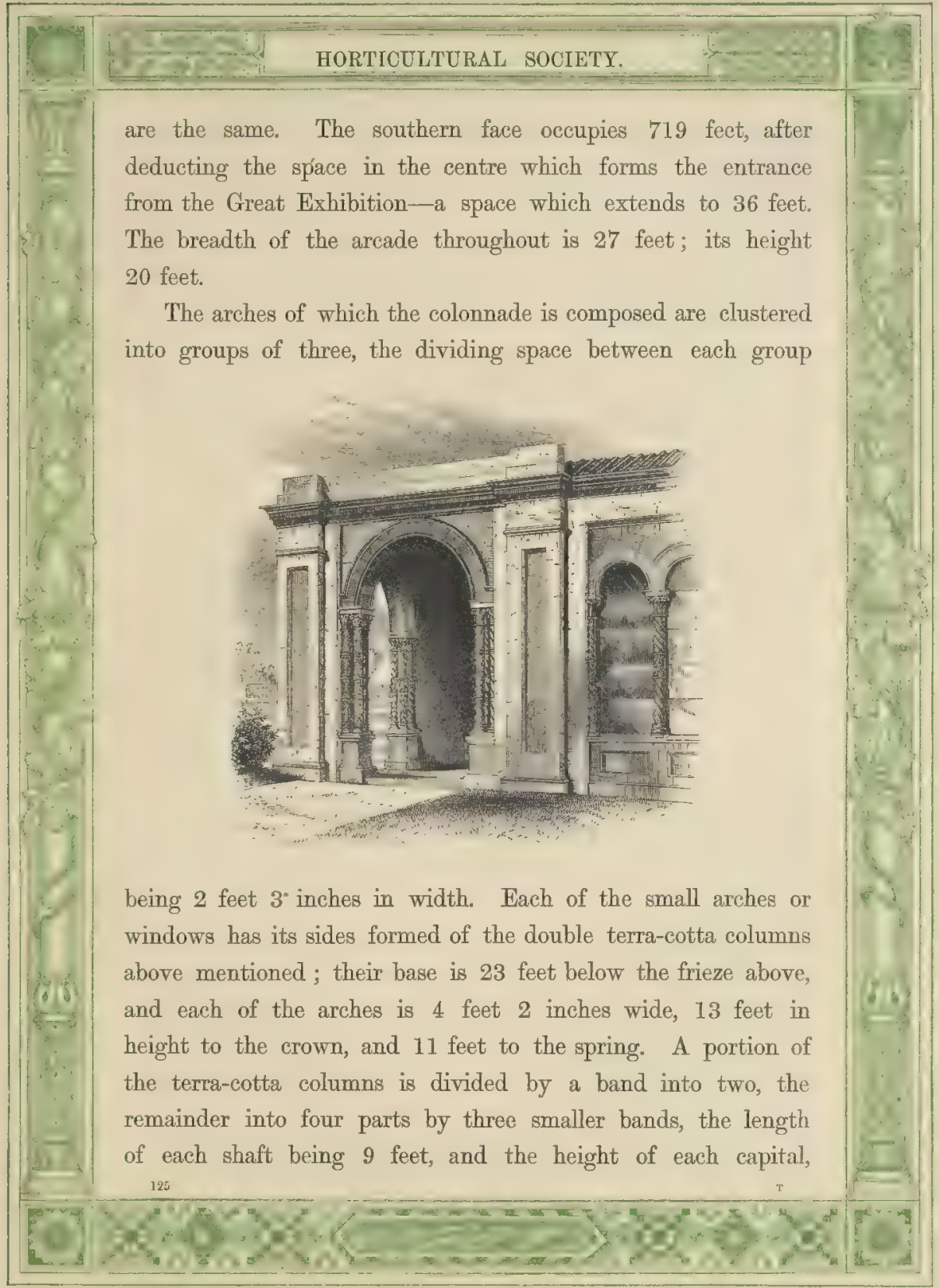


including an abacus of Portland stone, 1 foot 6 inches, making the height of the whole pillar 10 feet 6 inches. The thickness of the shaft is 8 inches. There are in all 203 arches, and 80 piers.

The wall is composed of red and yellow brick, and is surmounted by a frieze, as yet plain and unornamented, but which is intended at some future time to be richly decorated with fresco painting or majolica. Above the frieze, a cornice finishes the effect for the present, but hereafter the wall on the east and west portions of the Garden will be surmounted by a balustrade, in the same fashion as that on the top of the portico of the Council-room, the middle entrance from the Exhibition, and the western entrance.

The piers of the balustrades, which will be placed at distances of 18 feet, are to bear statues or large vases.

The whole south façade- except the central portion, which has a mezzanine interposed-is divided into two floors. The front is divided into five faces, in different lines of advance. By subdividing the centre mass into three sections, variety and relief of design have been obtained. The middle of the front is occupied by the entrance from the Exhibition Building to the Garden, through three 10-feet ornamented brick archways, supported by coupled stone columns; these are immediately opposite the southern entrance, from which point one unbroken vista is obtained across the whole Garden up to the Cascade and Conservatory at the north end.

The elevation of the five divisions of the façade (70 feet high) presents three levels - the terra-cotta arcades-the shallow mezzanine (interrupting the architectural arches) - and the upper refreshment rooms. On each side of the centre are the tripled 


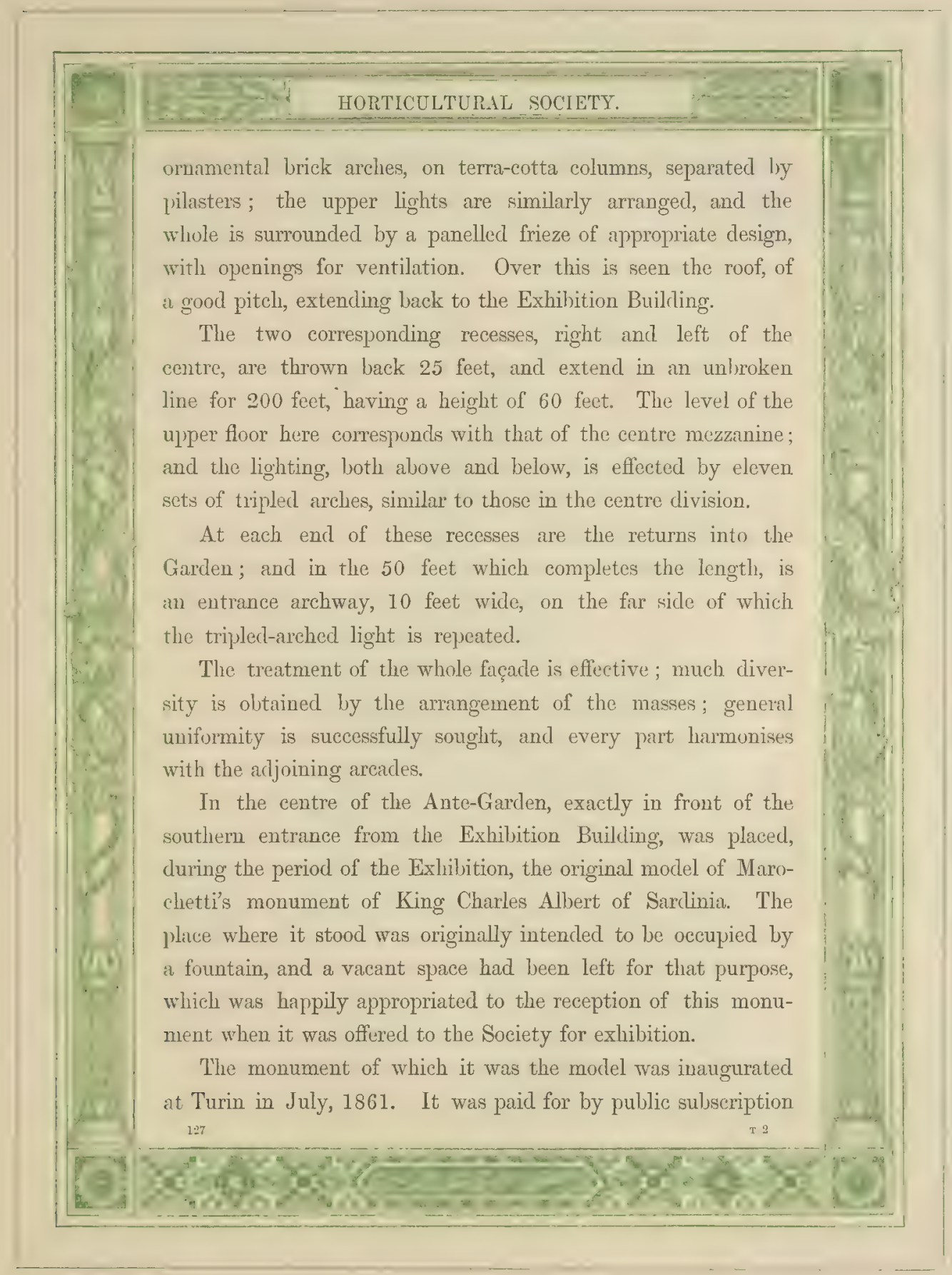




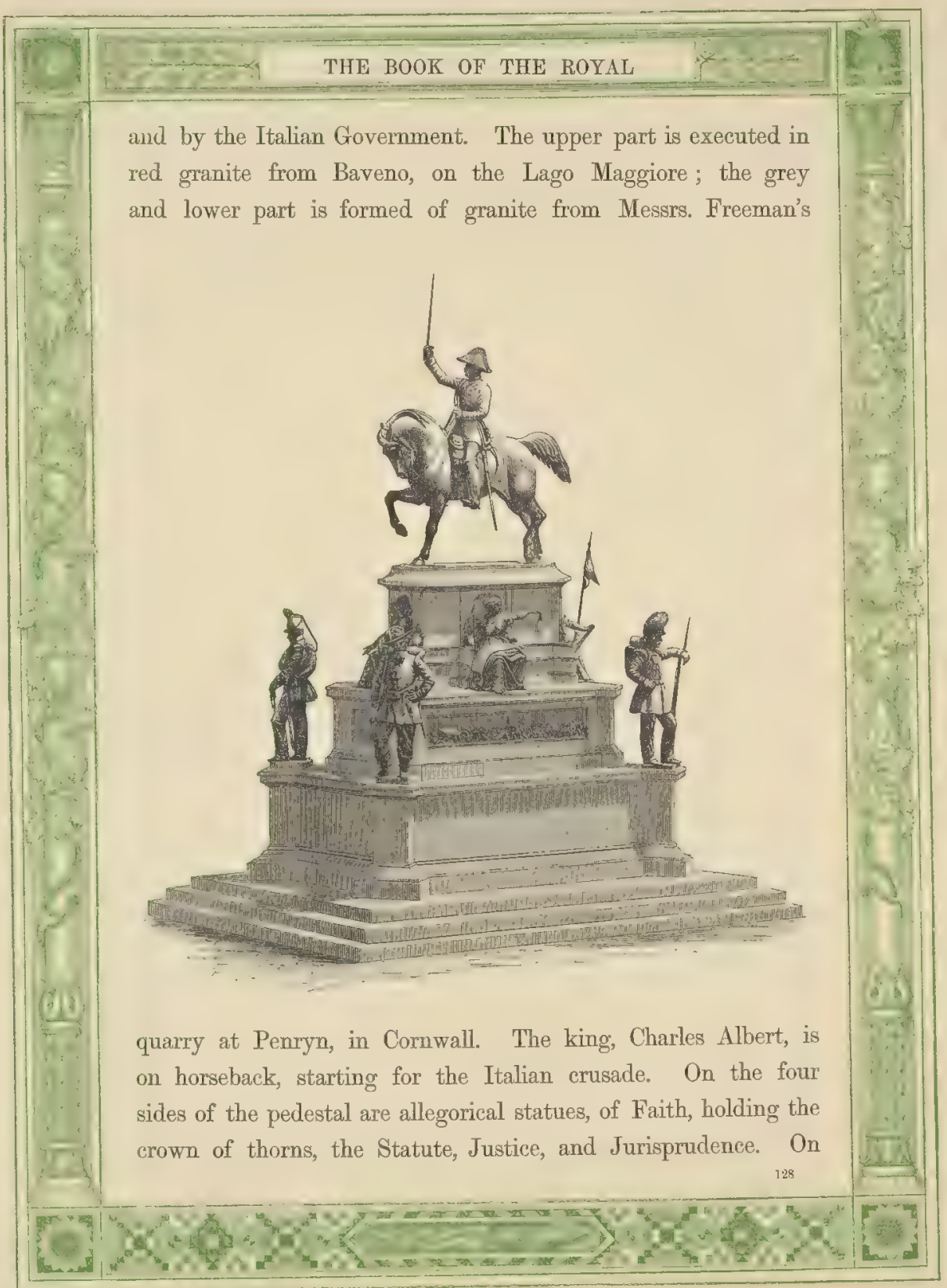




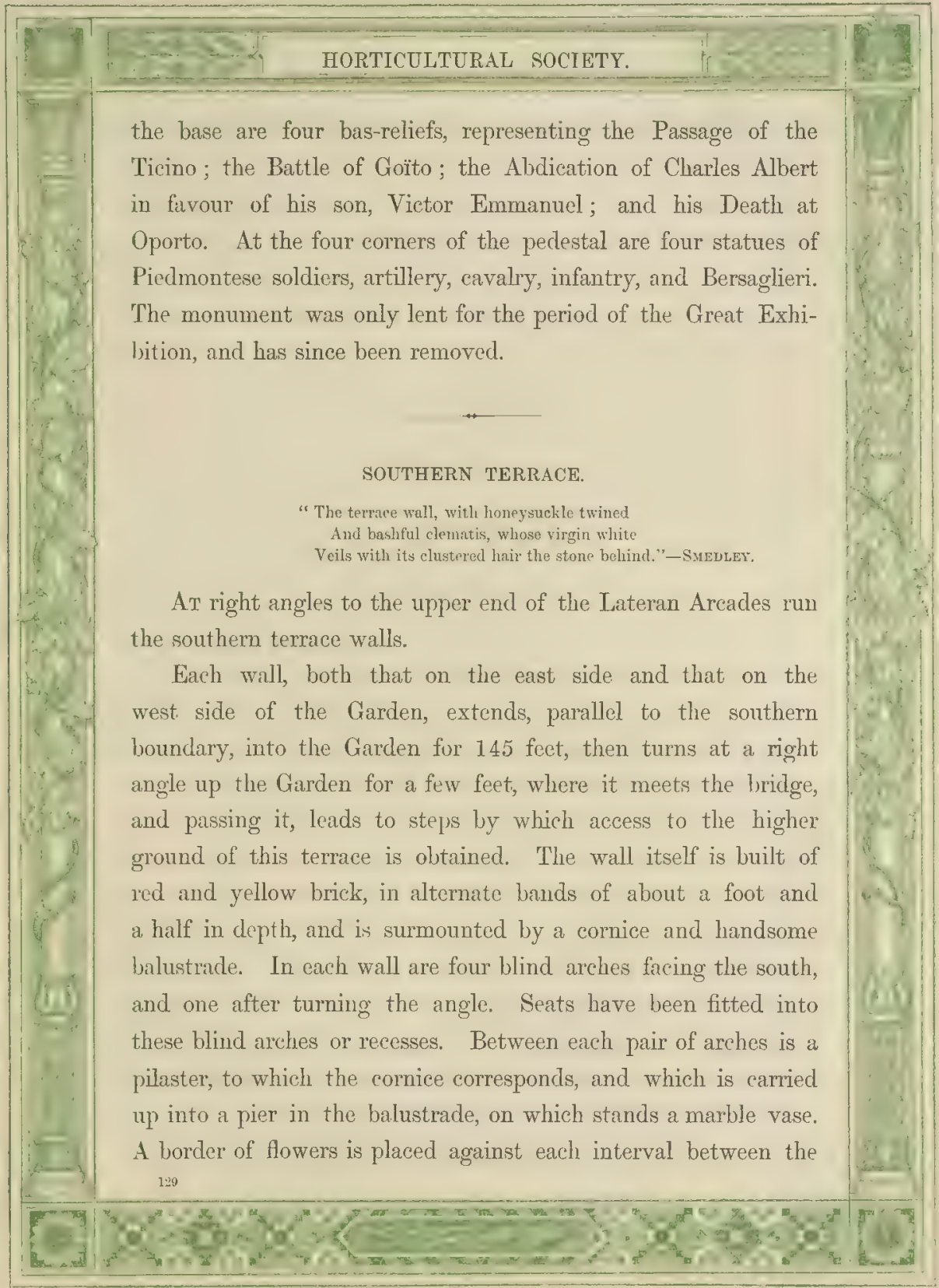




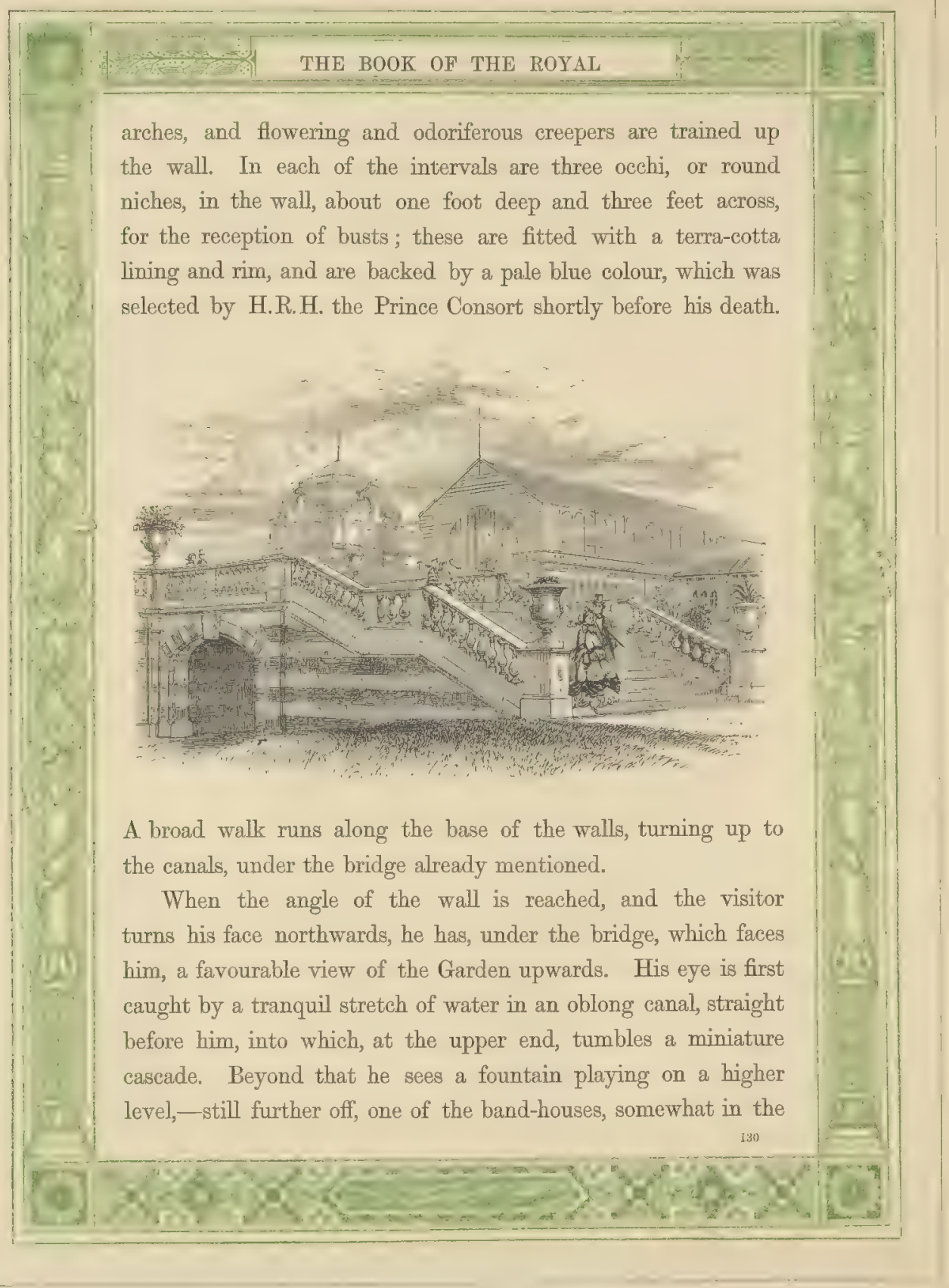




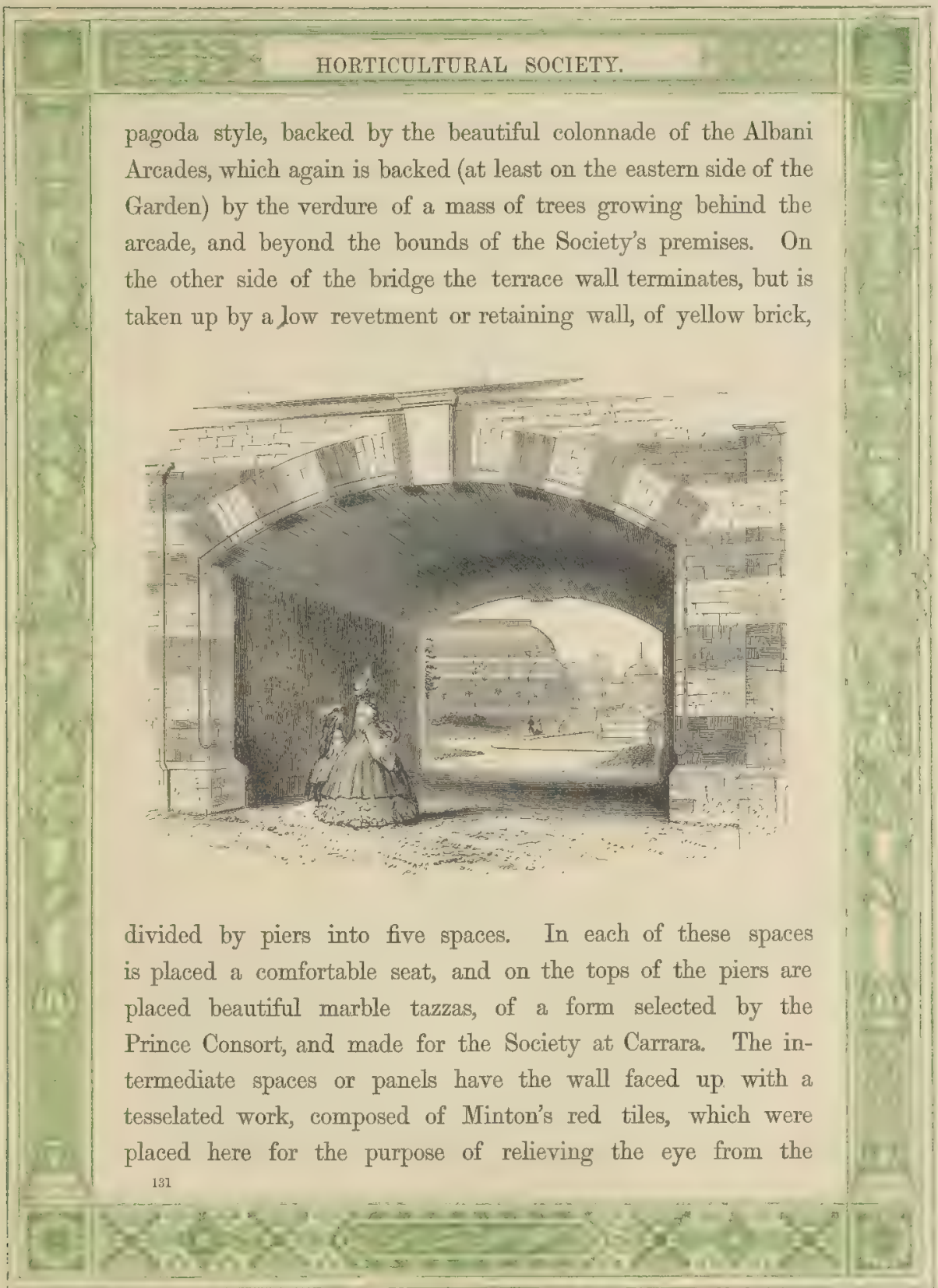




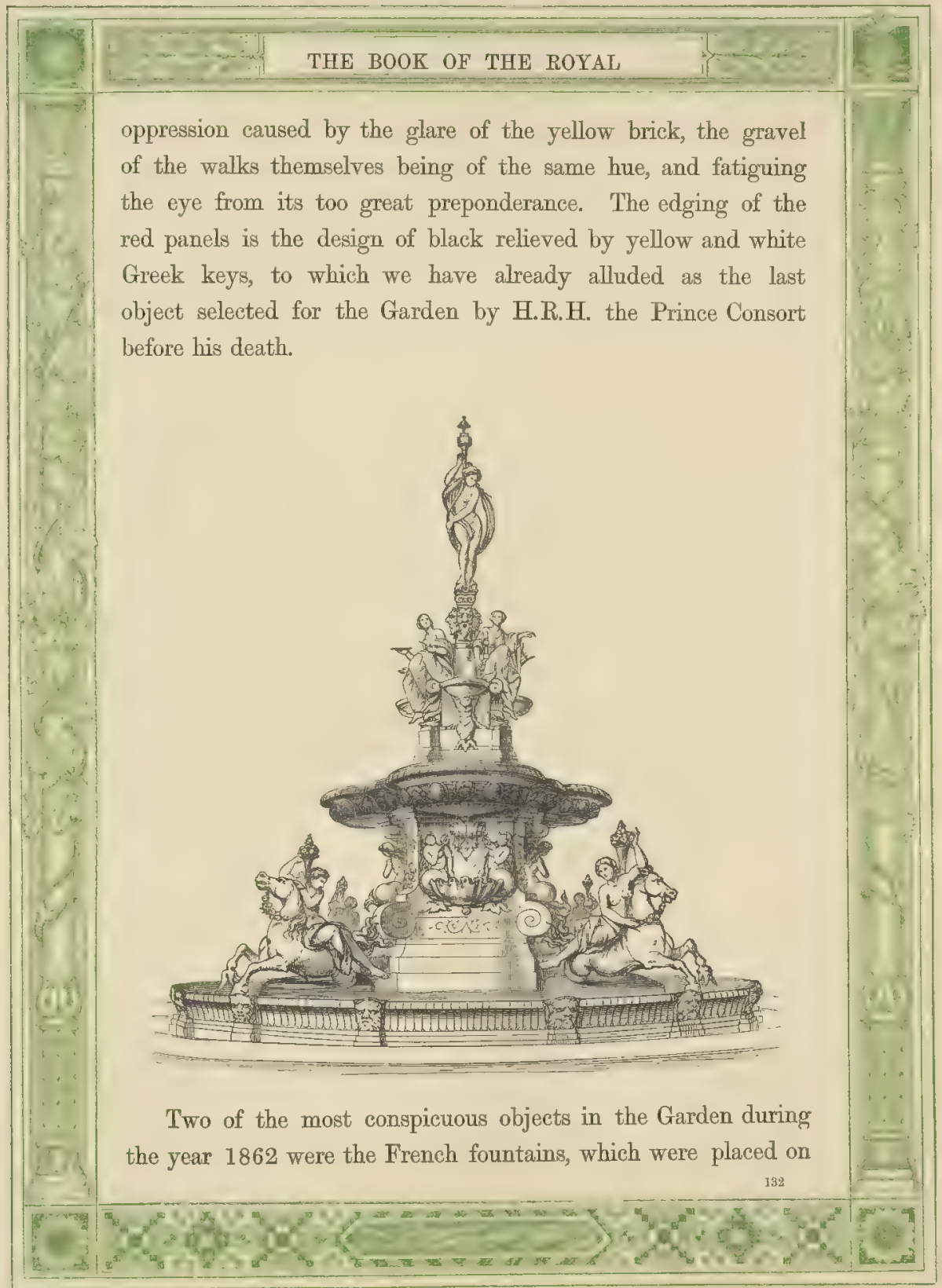




\section{HORTICULTURAL SOCIETY.}

each side of the middle walk, in a line with the southern terrace walls. The larger of them was constructed by M. Durenne, and was designed by Klagman, a French artist, from whose designs many of the iron and bronze castings shown by M. Durenne in the Exhibition were executed. It was intended for a much more extensive position than could

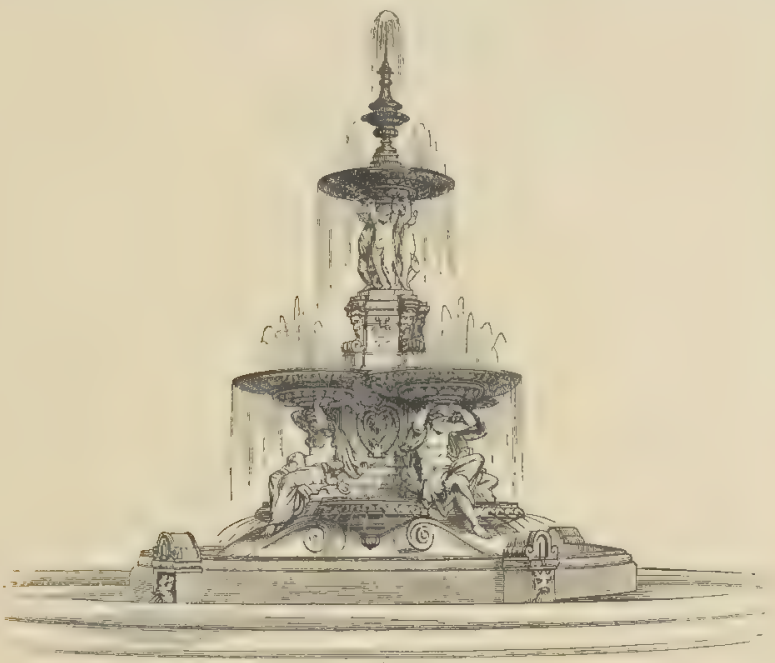

be given to it in the Garden. As it was, the outer basin, which (to correspond with the dimensions of the gigantic sea-horses disporting themselves in it) should have been a small lake, was cabined, cribbed, and confined within the smallest possible dimensions, so as to be symmetrical with its neighbour and kept within the space which could be afforded it. The spirited colossal sea-horses and the elaborate richness of the figures forming the central group have been much admired. 133 


\section{THE BOOK OF THE ROYAL}

The other fountain, the work of Messrs. Barbezat, was smaller in proportions, less ambitious in design, and better suited to the dimensions of the Garden. It was designed by M. Morean, another French artist, not less celebrated than M. Klagman.

The water display of the fountains in 1862 was rarely seen to full advantage; it was worked by the steam power used for the machinery in the Western Annexe of the Exhibition, the claims upon which were so overpowering that the fountains could seldom procure an adequate supply of steam, and when they did, it was only for a very limited period.

\section{MILANESE ARCADES.}

"Not distant far, a length of colonnade

Invites us. Moument of ancient taste!Our fathers knew the value of a screen From sultry suns." - COW PER.

THE central or Milanese Arcades are on a higher level than the southern arcades, and access is had to them under cover by steps leading from the southern or lower colonnade. Their style is borrowed from examples of Milanese brickwork of the fifteenth century, and they were designed by Mr. Sydney Smirke, R.A. They are 630 feet long, 20 feet high, and 24 feet wide. They consist of a series of arches (39 in number, on each side of the Garden) 10 feet 9 inches wide, 12 feet 6 inches in height to the spring of the arch, and 17 feet 8 inches to the crown of the arch. The arches are separated from each other by pilasters of red brick, with capitals of Portland stone, which, with the exception of one or two, cut as examples, are yet unhewn; and, shrouded within the solid stone, no one can say what 
lovely, grotesque, or striking idea may be evoked by the chisel of the sculptor, perhaps long after the fertile brains and critical eyes of those who planned it have ceased to work.

As already mentioned, throughout the works constructed in this Garden, the admirable plan has been adopted, wherever it could possibly be done, of having the effect of everything which has been executed previously tried, not only by a model, but by a full-sized model of the work. The models or full-sized paintings of these arches still remain on a blank wall behind the Kensington Museum, and show the steps by which they gradually advanced from the first germ to their present beautiful proportions.

At the top, centre, and bottom of each of these central arcades are three arches, separated from each other by wider piers, furnishing four spaces, in each of which is a niche for the reception of a statue.

The spandrils between the arches contain a round recess intended to contain a medallion in majolica or other ware, and the spandrils and frieze are intended to be decorated in the same manner, or by frescoes or tiles. The cornice is finished off much as in the southern arcades, and will, when completed, be like it.

It is intended that the floor of these arcades shall be laid with tiles, or asphalte, of different patterns, disposed in such a manner as to form a harmonious whole.

It was originally intended that the back wall and roof should be embellished with frescoes, and the roof ornamented with designs in panel, but it is not improbable that some modification may be made in this design. 


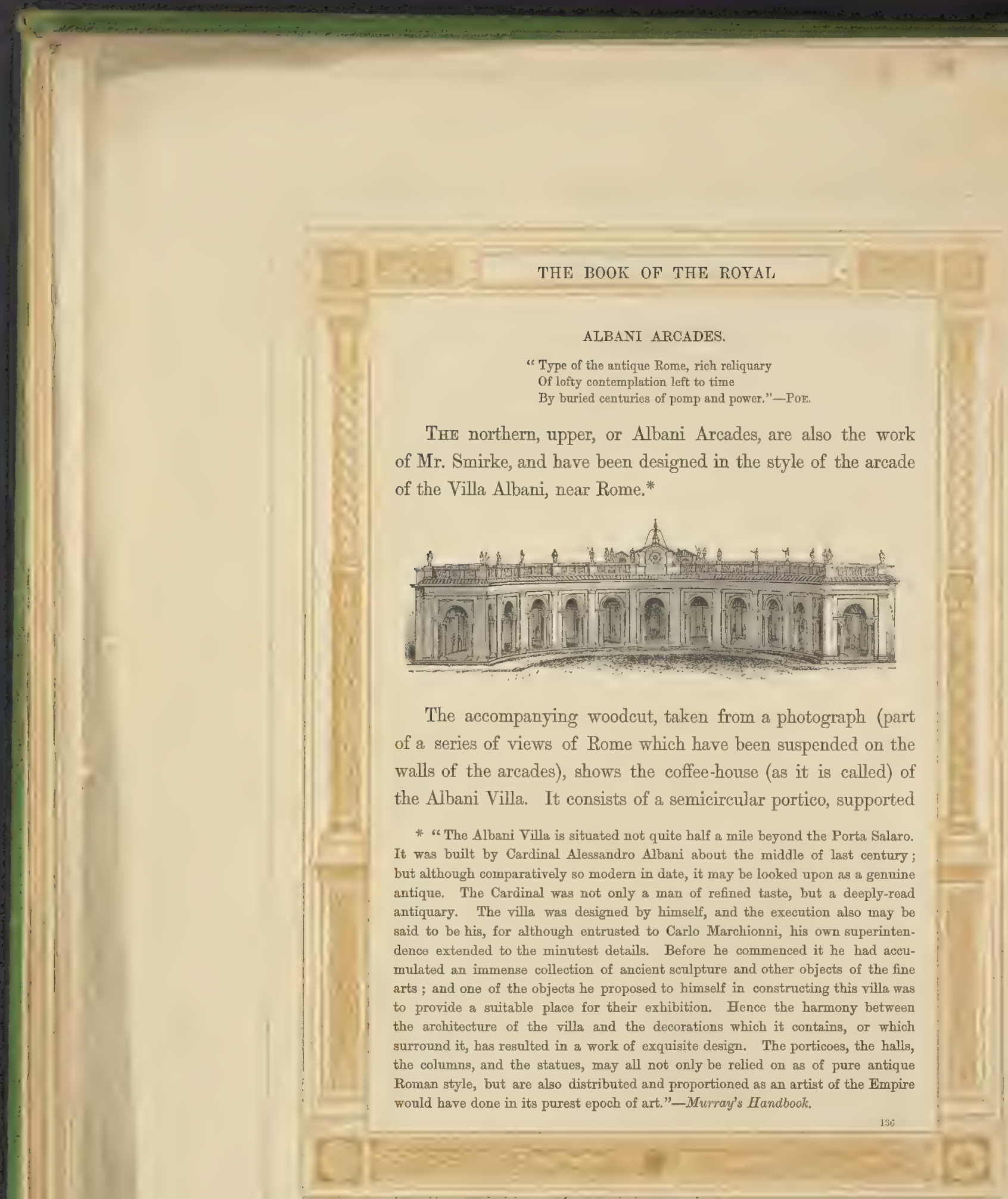




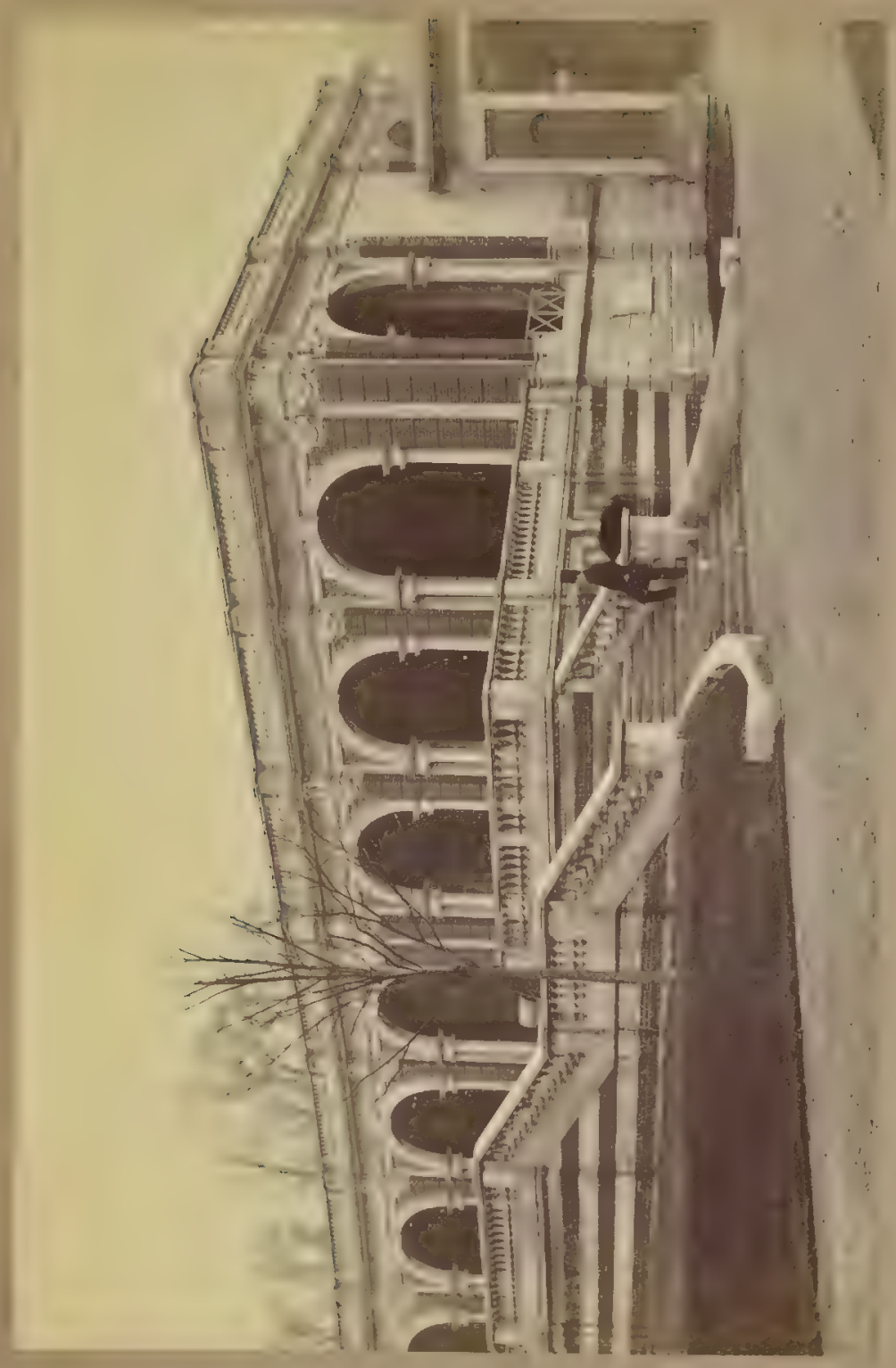



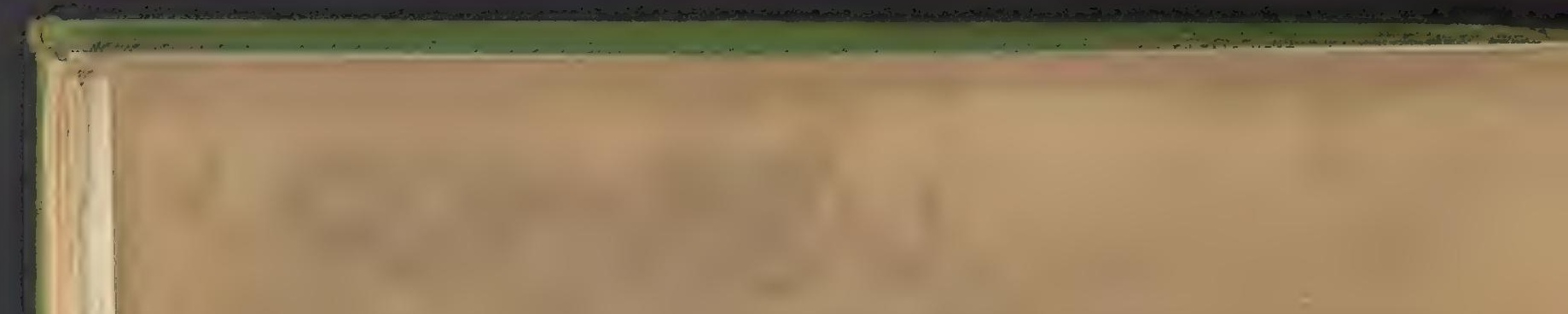
by columns of granite, forming an arcade, in which are arranged statues, busts, and other works of art. The engraving gives a general idea of the style of these buildings, and may suggest the origin of some of the arrangements in the Royal Horticultural Garden.

The casino, or villa, of the family of the Sachetti, at Rome, is quite in the same style, and may possibly also have contributed somewhat to the ideas introduced into the Garden at South Kensington.*

The arcade is semicircular, 600 feet long, 26 feet wide, and 22 feet in height, and embraces in its centre the Conservatory. The arches are 10 feet 7 inches wide, 18 feet 9 inches to the crown of the arch, and 13 feet 6 inches to its spring; the pillars on each side are 1 foot 1 inch in thickness, the pilaster or pier between them is 2 feet in breadth, and is finished by a capital executed in terra-cotta. There are 38 arches, 42 pilasters, and 42 shields.

The decorations of the frieze and spandrils have been completed on one arch, to show the style of decoration which is intended to be followed. Each pilaster has a shield over it, also executed in terra-cotta, and containing an impressed and painted or gilded figure of some one of the natural orders of plants, with its name below it.

On the occasion of the opening of the Society's Great Show, on the 5 th of June, 1861, and on some of the subsequent Flower Shows, the whole extent of the Albani Arcades has been crowded

* It was built from the plans of Pietro Barettini, of Crotona, and may be cited as an extreme example of the luxuriant richness of embellishment of the high Italian School. 


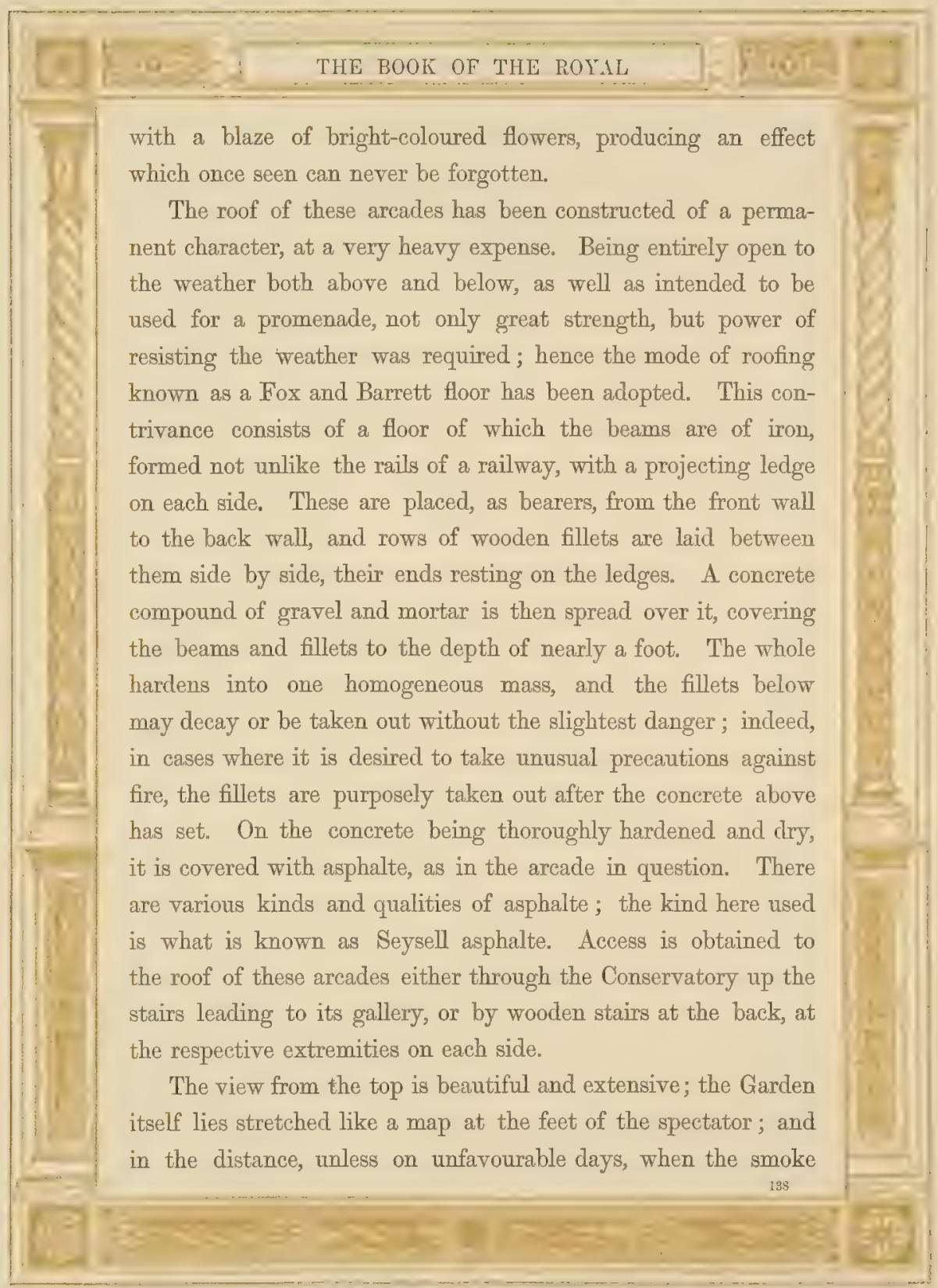




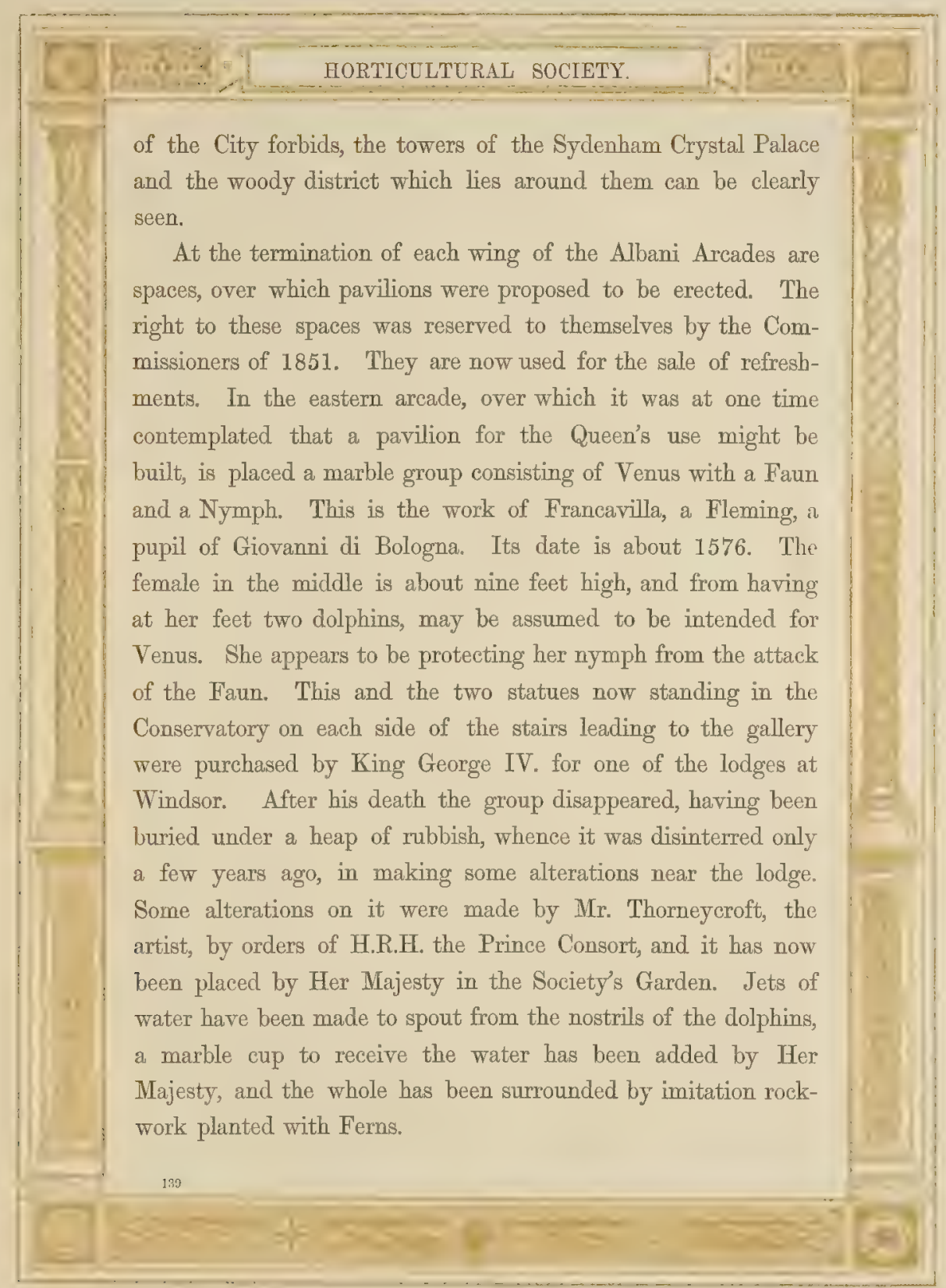




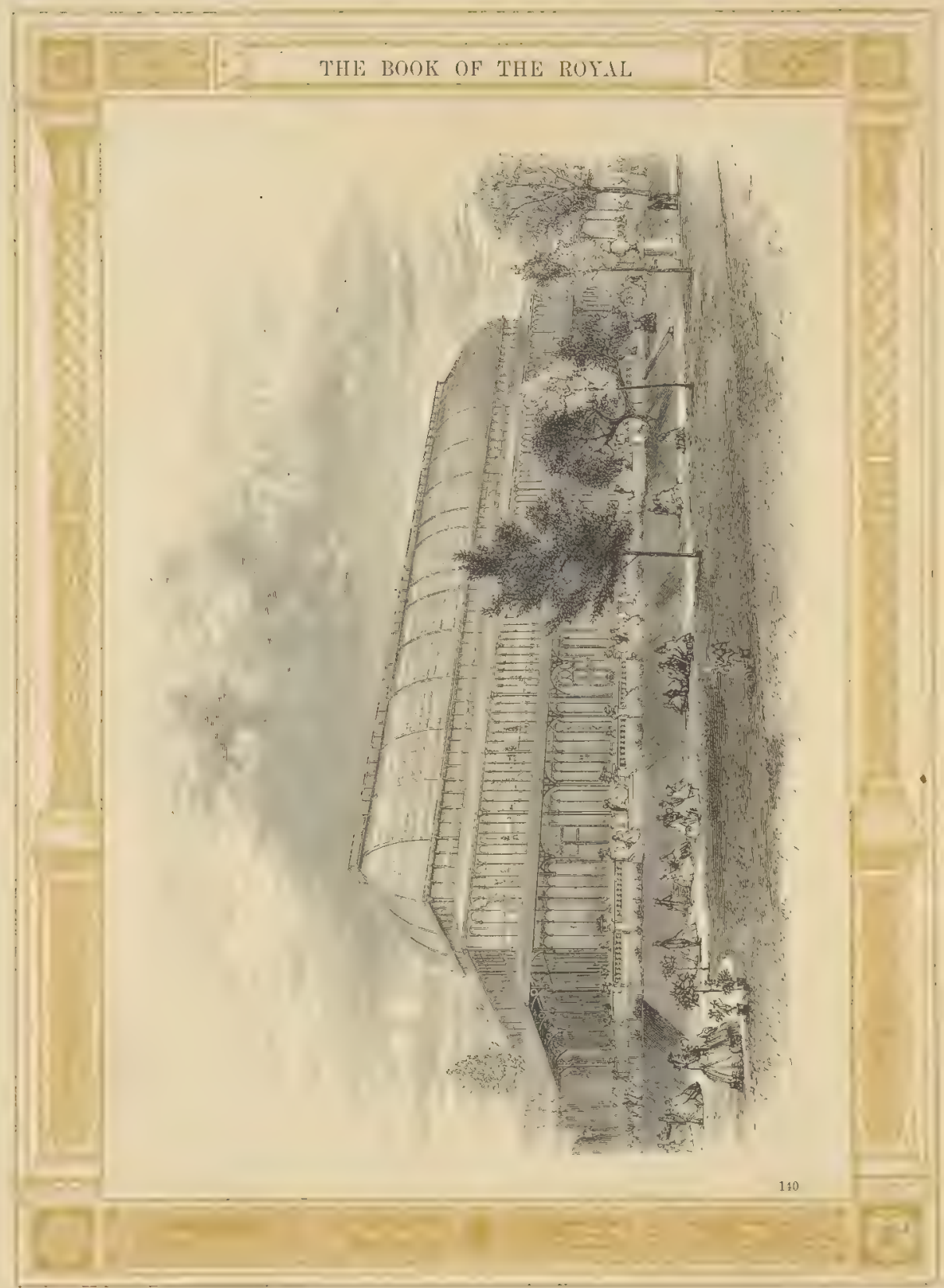




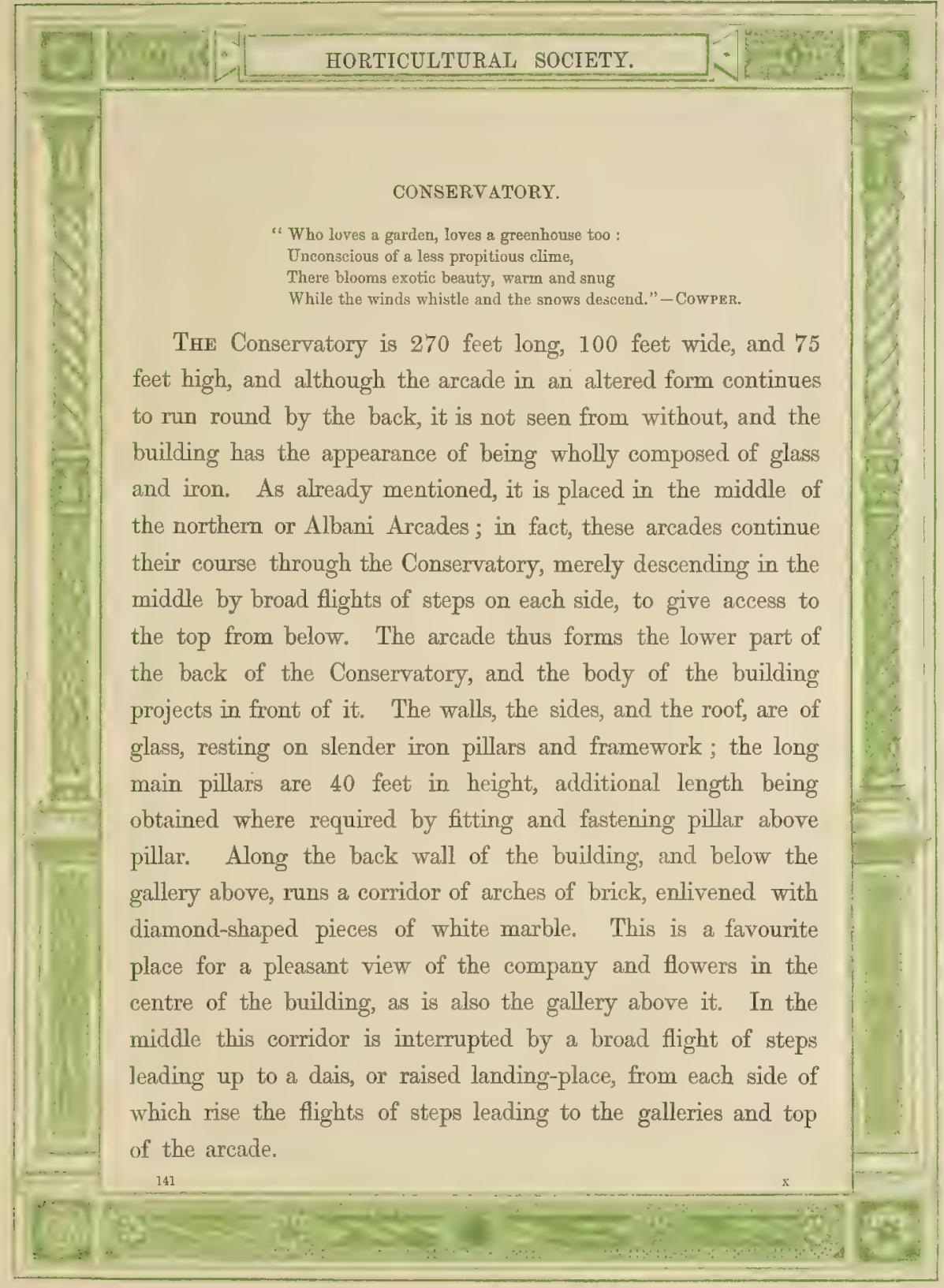




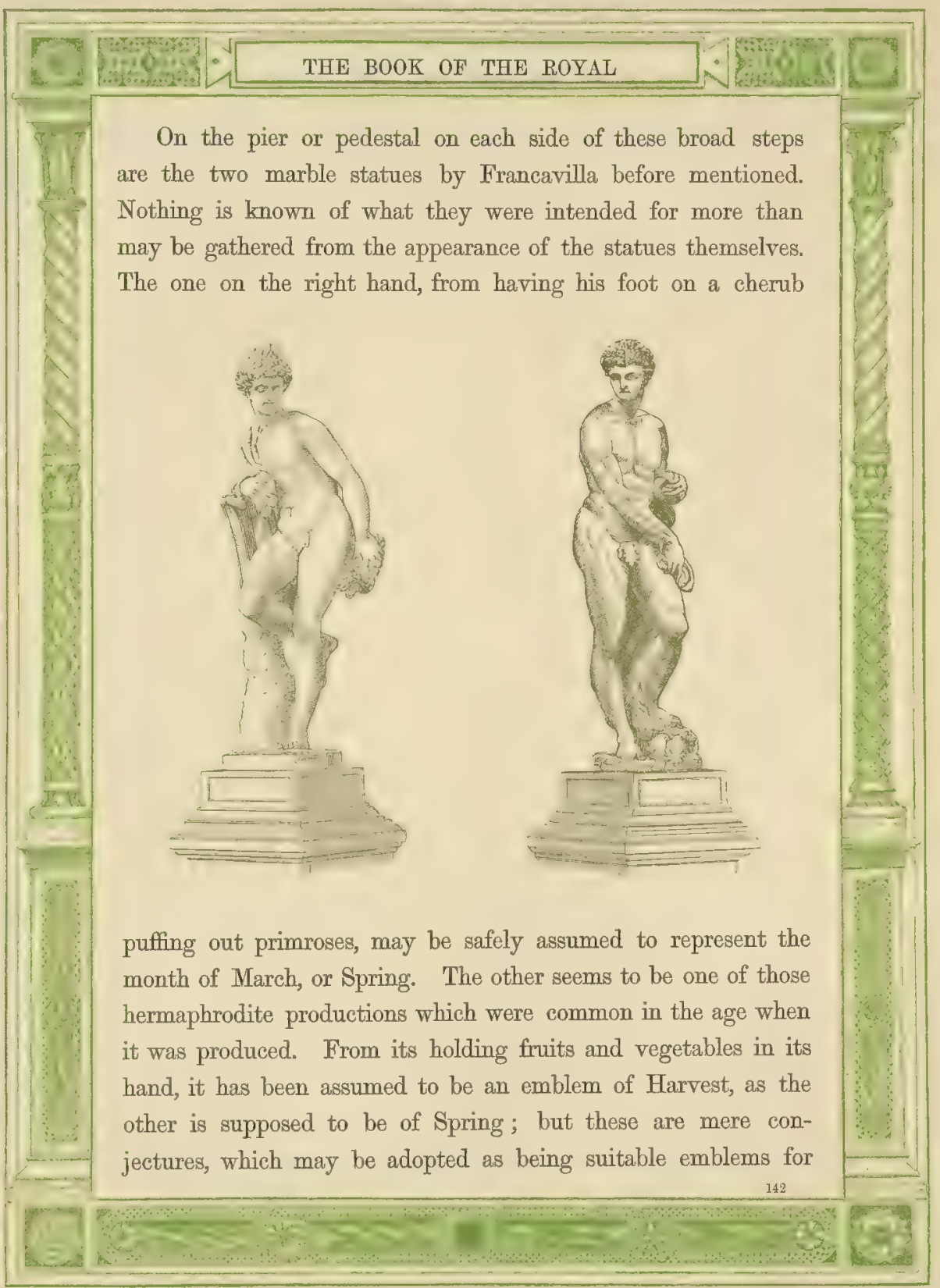




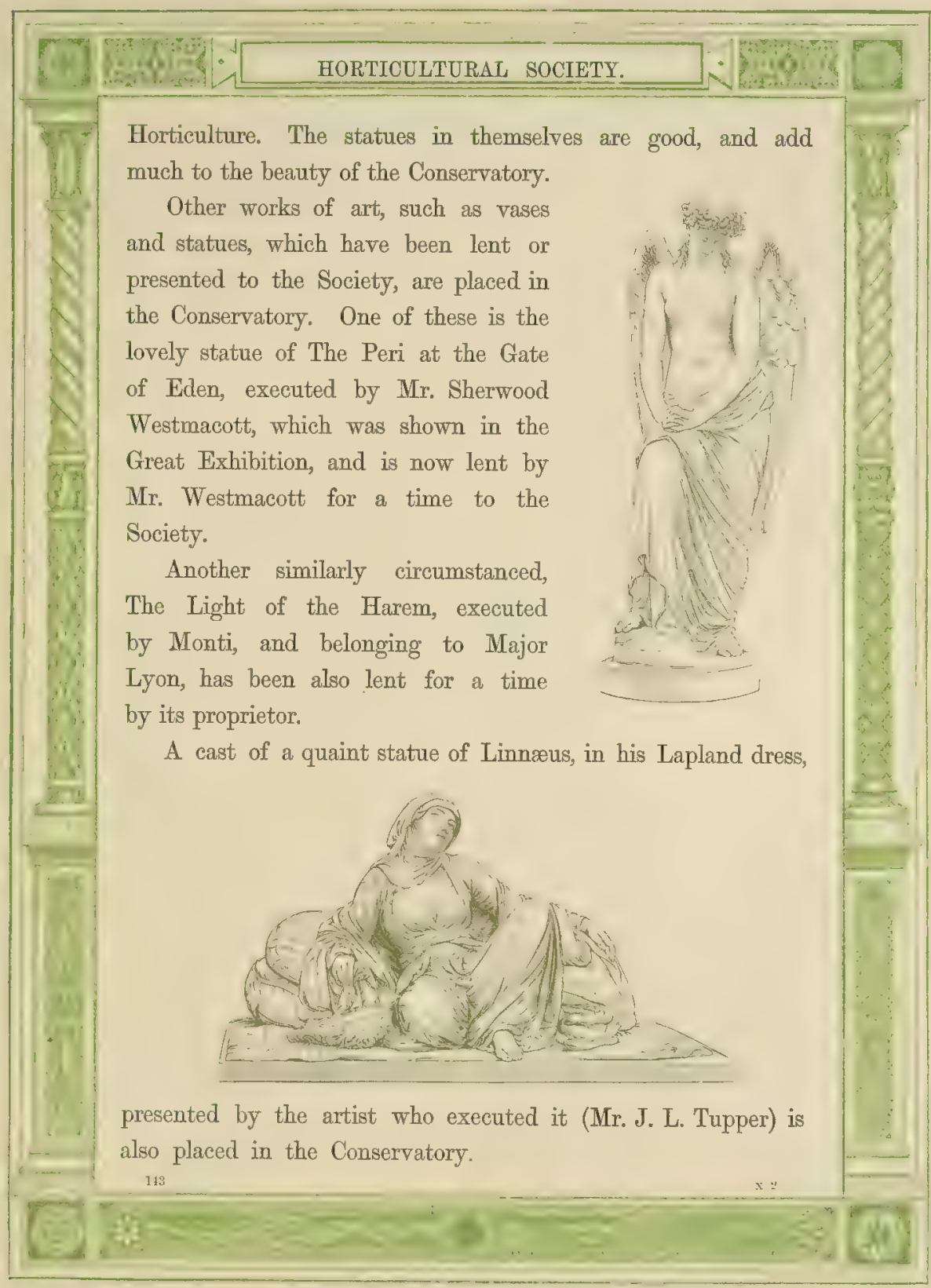




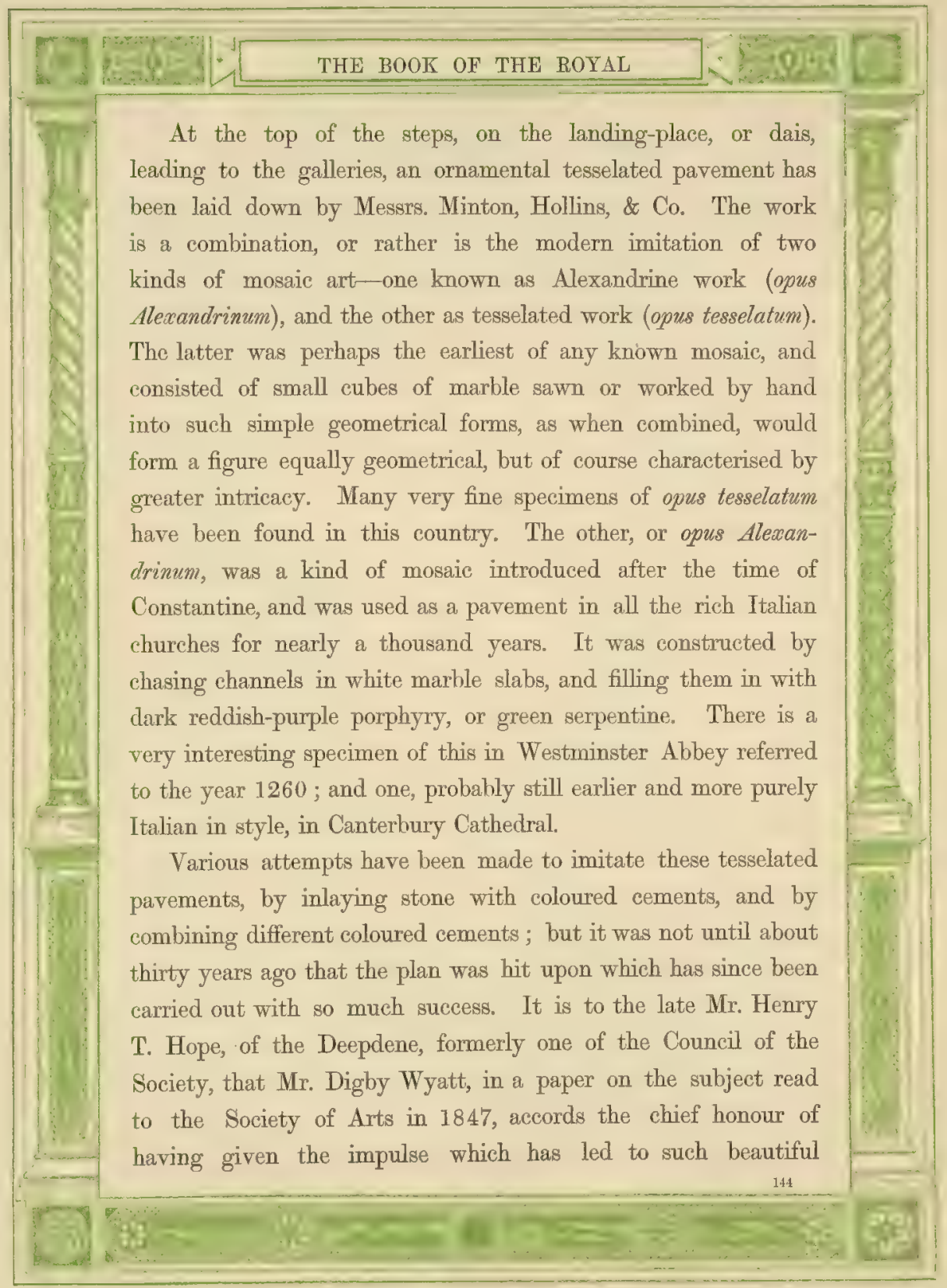




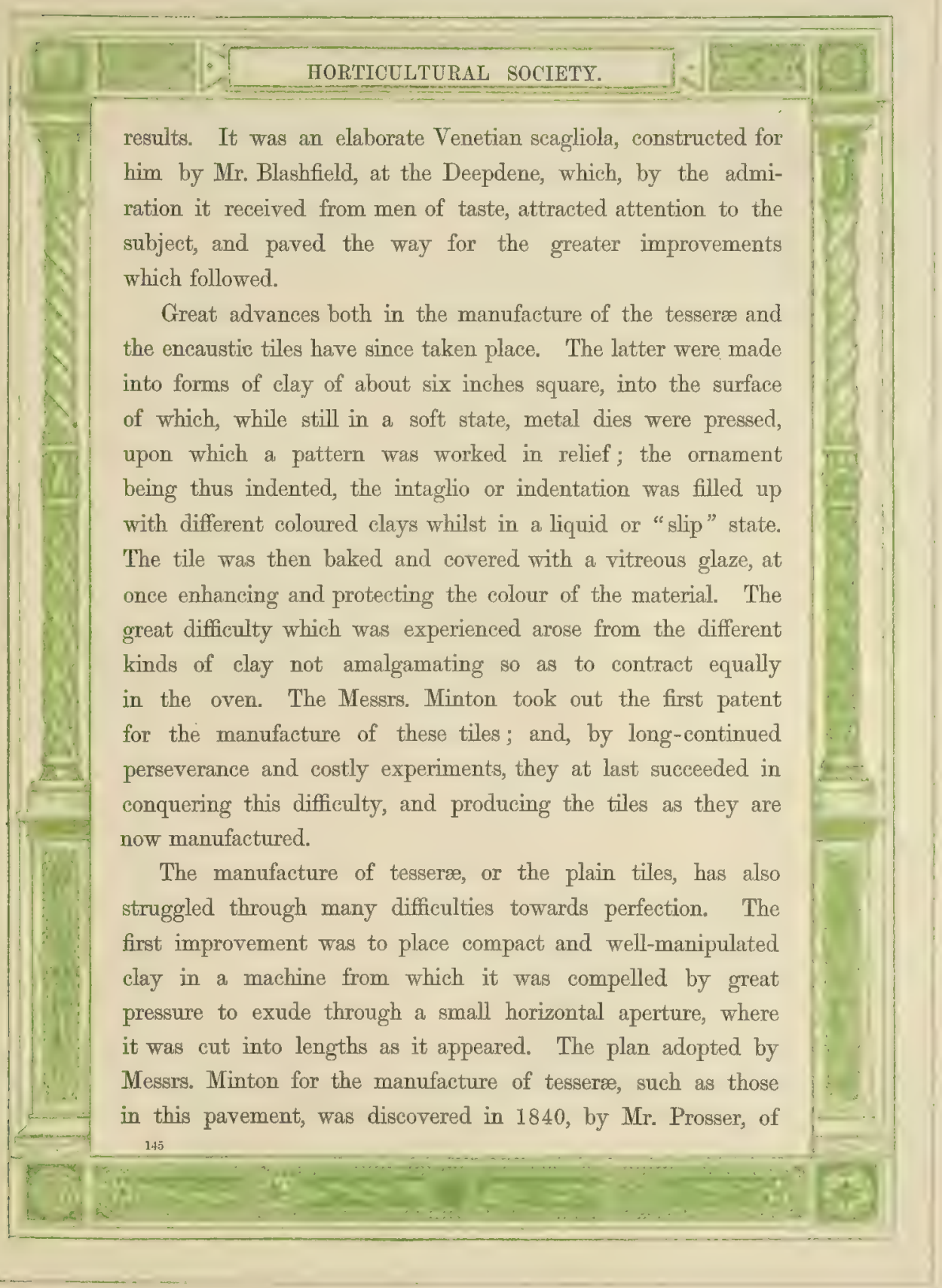




\begin{tabular}{|c|c|}
\hline & THE BOOK OF THE ROYAL \\
\hline & $\begin{array}{l}\text { Birmingham. "He found," to quote the words of Mr. Ward, in } \\
\text { a paper in Mr. Blashfield's work on mosaic floors, "that if the } \\
\text { material of porcelain (a mixture of flint and fine clay) be } \\
\text { reduced to a dry powder, and in that state subjected to strong } \\
\text { pressure between steel dies, the powder is compressed into about } \\
\text { a fourth of its bulk, and is converted into a compact substance } \\
\text { of extraordinary hardness and density, much less porous and } \\
\text { much harder than the common porcelain uncompressed and baked } \\
\text { in the furnace." Messrs. Minton \& Co. apply hydraulic pressure } \\
\text { to this part of the manufacture, under which, at every stroke of } \\
\text { the press, the powdered clay is converted into a solid tile. } \\
\text { The design of the pavement in the Conservatory is the work } \\
\text { of Mr. Harry Green, formerly a student in the Department of } \\
\text { Science and Art, and now attached as artist to Messrs. Minton \& } \\
\text { Co's establishment. It is not of any particular school or period, } \\
\text { but is derived from the Pompeian, Early Italian, and Renaissance } \\
\text { art. The white, green, and red tesselation has considerable } \\
\text { resemblance to an elaborate slab now placed in front of the } \\
\text { high altar in the church of Santa Maria in Transtevere at } \\
\text { Rome, and the same colouring and general effect may be met } \\
\text { with in most of the churches in Italy which contain any } \\
\text { pavement of this character. } \\
\text { This class of manufacture has now reached such perfection, } \\
\text { and has so much character of its own, that it can scarcely } \\
\text { perhaps be treated as an imitation, at least to the extent } \\
\text { of estimating its worth by the nearness of its approach to } \\
\text { the material imitated. The materials used by the Romans to } \\
\text { produce the different colours were these :-a slightly clouded } \\
\text { yellow Sienna marble gave the light buff ground; morsels of } \\
\text { a }\end{array}$ \\
\hline
\end{tabular}




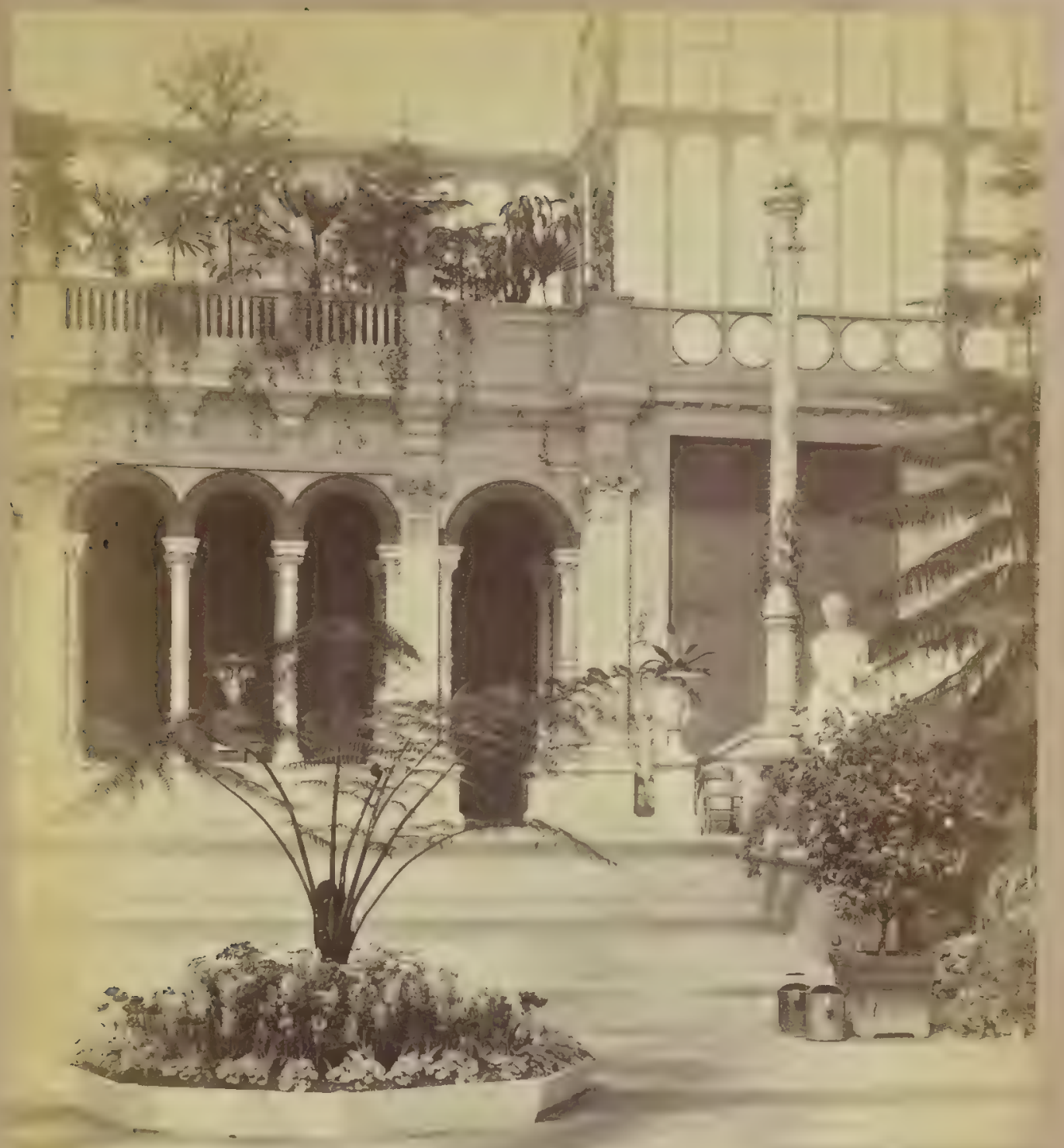





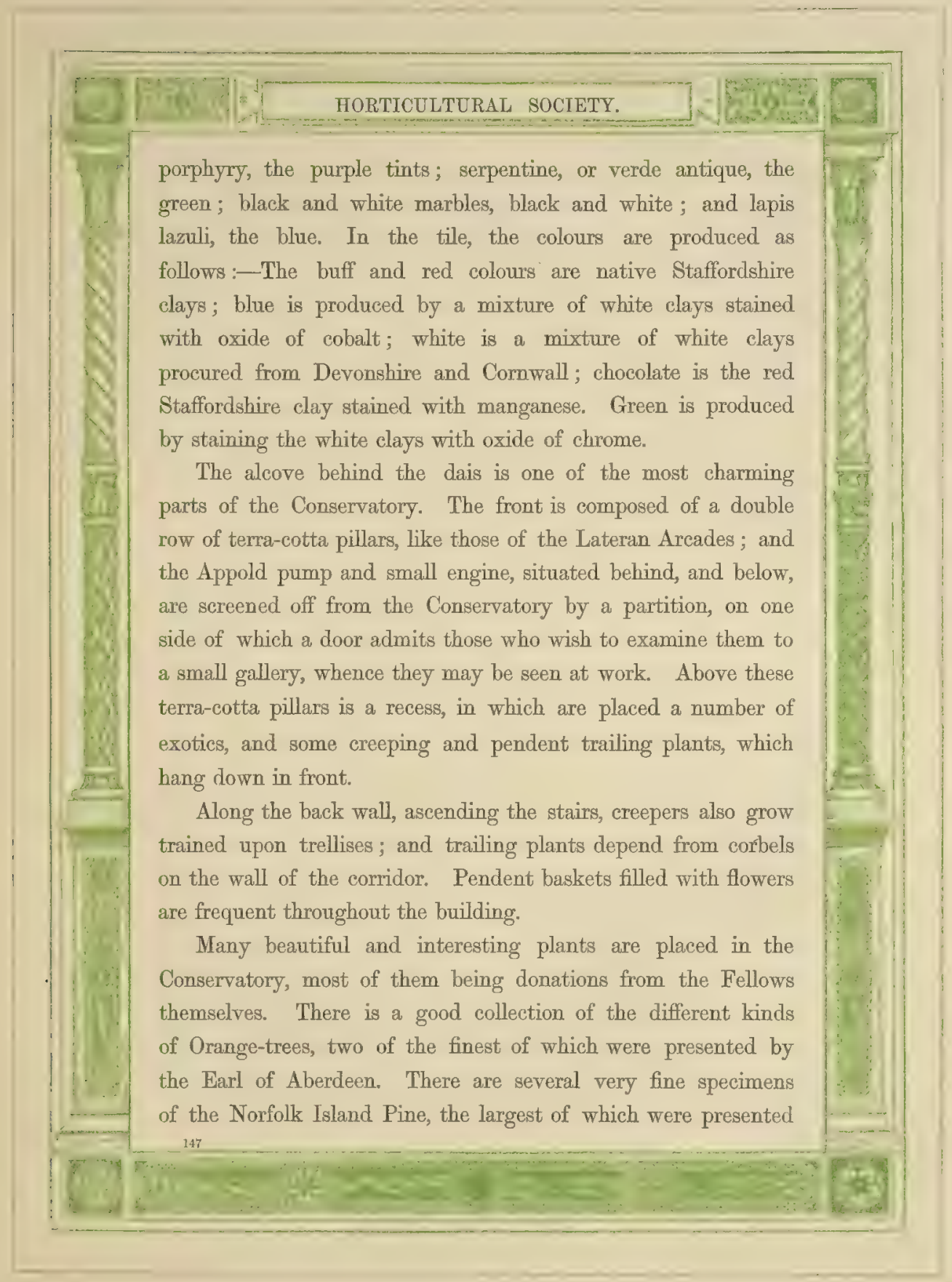




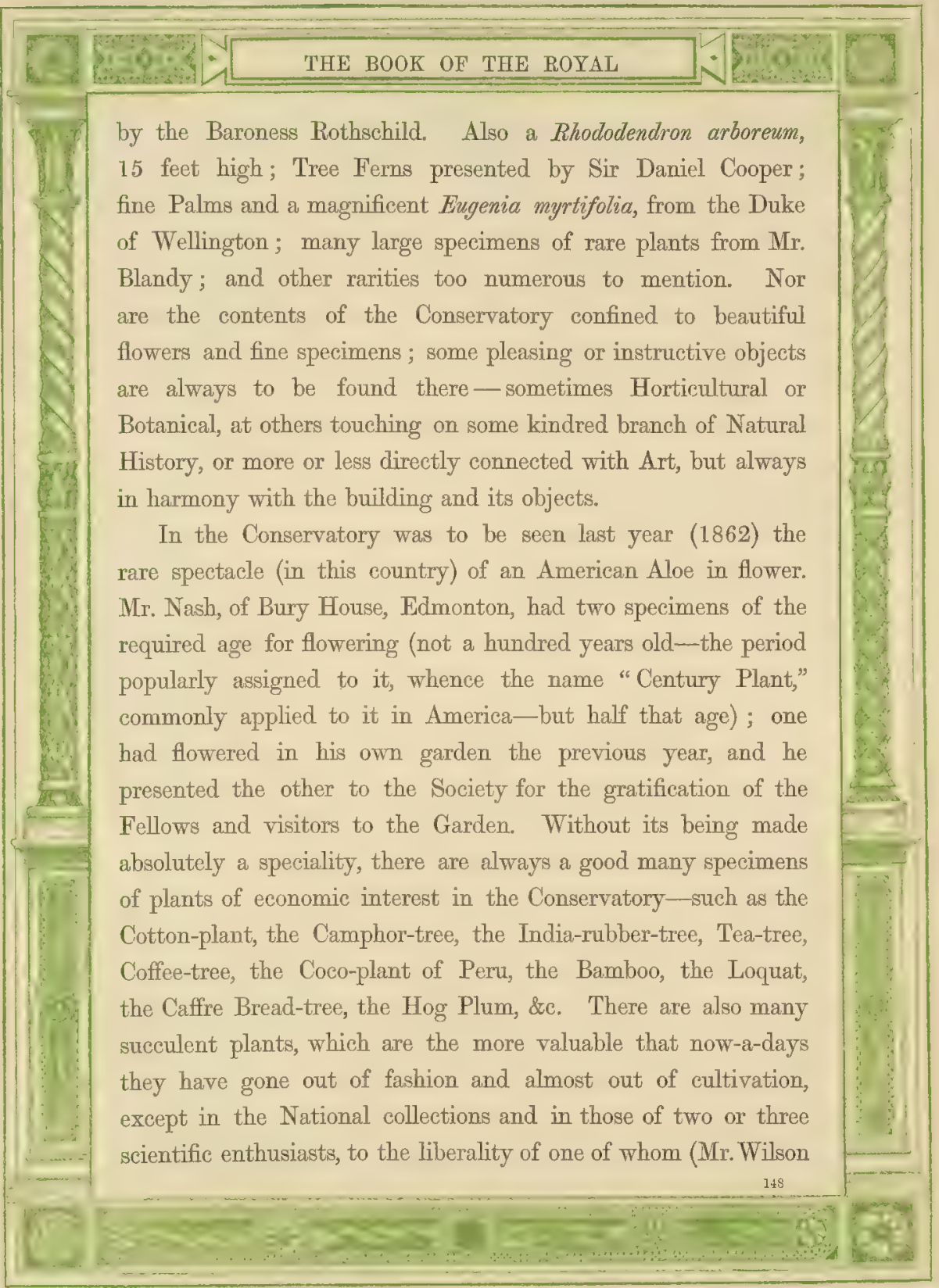


the wall, in which climbing plants may grow and creep up behind the tables, space being left for this purpose. The margin of each table is fitted with a handsome fringe or edging of wire, worked into a sort of ledge, expanding both upwards and downwards, looking like filagree work. Within this are placed the pots, the interspaces as well as the outer edging being filled with Lycopods and green Moss.

The heating of the Conservatory has been executed upon the most approved principles of modern science.

Since 1851 a considerable change has taken place in the plans commonly adopted for this purpose. It was then thought that the mere introduction beneath the floor of a number of pipes duly charged with hot water, with a grating in the floor for the ascent of the heated air, was sufficient to raise the temperature of the apartment to any desirable degree. It was believed that air, being heated, would ascend of itself, and that when the hot-water pipes were once laid down, all that was necessary had been done. It is now admitted that, unless there are some means of introducing a certain regulated quantity of cool air beneath the pipes, more than half their effectiveness will be wasted. The first idea would naturally be to bring cold air from the outside of the building, but on reflection it will be seen that this would not only supply the place of the ascending hot air, but also chill the house as much as the hot air heats it. What is wanted, therefore, is air only so much cooler than that affected by the pipes as to cause it to ascend, and the air most suited for this is the atmosphere of the building itself. The application of this fact to practice requires, if not scientific skill, at least some experience; and a good accidental illustration of the consequences of 


\begin{tabular}{|c|c|}
\hline & 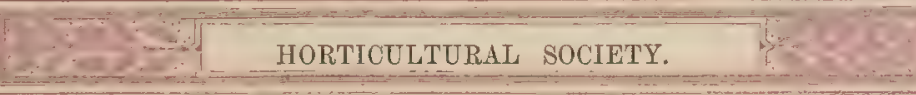 \\
\hline 8 & $\begin{array}{l}\text { not attending to it may often be seen in buildings, such as } \\
\text { churches, where there is a succession of galleries, the whole } \\
\text { floors usually forming series of natural gratings, and the descent } \\
\text { and ascent of cool and heated air going on continuously : but } \\
\text { from the absence of some contrivance to secure the application of } \\
\text { the atmospheric air to the hot-water pipes, the cool air descends } \\
\text { only to the first series of pipes, and an immense waste of power } \\
\text { is of course the result. The system of heating the Houses of } \\
\text { Parliament was found defective from this circumstance, the cool } \\
\text { air being brought at once from the outside instead of from } \\
\text { another part of the buildings; hence the succession of hot and } \\
\text { cold draughts, which were found so unbearable in winter and so } \\
\text { disagreeable at all seasons. In the system at present adopted by } \\
\text { the Royal Horticultural Society, provision is made not only for } \\
\text { heating, but also for circulating the atmospheric air throughout } \\
\text { the building, and conducting it beneath the hot-water pipes. } \\
\text { Channels for the introduction of cold air from the exterior } \\
\text { of the building, when necessary, are also provided; but these } \\
\text { channels are fitted with registered ventilators, so as to allow } \\
\text { the supply of fresh air to be regulated, and to admit only a } \\
\text { limited supply during inclement weather, as well as to prevent } \\
\text { draughts. } \\
\text { The hot-water apparatus erected in the Conservatory is in- } \\
\text { tended to accomplish a twofold object, namely, to warm the } \\
\text { building efficiently, and to promote a thorough and satisfactory } \\
\text { ventilation. } \\
\text { By means of boilers, circulating castings, ventilating grates, } \\
\text { air-passages, and valves, the heating and ventilating are made } \\
\text { in a great measure self-acting. } \\
\text { 151. }\end{array}$ \\
\hline
\end{tabular}


The boilers are of upright tubular construction, and connected with similar hollow furnace-bars, through which the whole of the water passes previous to entering the boiler. The water is thus made to pass beneath the fire, and so to secure the benefit of that heat which ordinarily descends into the ash-pit and is wasted. Each of these boilers contains 76 tubes, and exposes a heating surface of about 400 superficial feet to the immediate action of the fire; hence, by applying a simple formula (one foot of boiler surface acted on by the fire being capable of heating about 35 feet of 4 -in. pipe) we find that each of these boilers is capable of heating not less than 14,000 feet.

The boilers, placed in their respective positions, are connected at the top by circulating castings. These castings are fitted with two metal valves, 6 inches in liameter; so that by the regulation of the valves the water can be shut off from one boiler while the other is working the apparatus, as, for instance, during repairs or other alterations. Nor is this the only precaution adopted: two separate mains, of large diameter, are brought from the boilers into the Conservatory. These also are each fitted with additional valves, in order to render the whole doubly secure. Thus, if any portion of the apparatus were to become disarranged, half the quantity only of the pipes might be heated, and half the water withdrawn.

The galleries of the Conservatory are heated on a somewhat lifferent principle. Here there were no means of placing pipes below the floor, and an unsightly barrier of pipes four deep, ne above the other, running round the gallery, is avoided by adopting tubular coils, which are treated as pedestals, and used as stands for ornamental objects. A small boiler of similar con- 


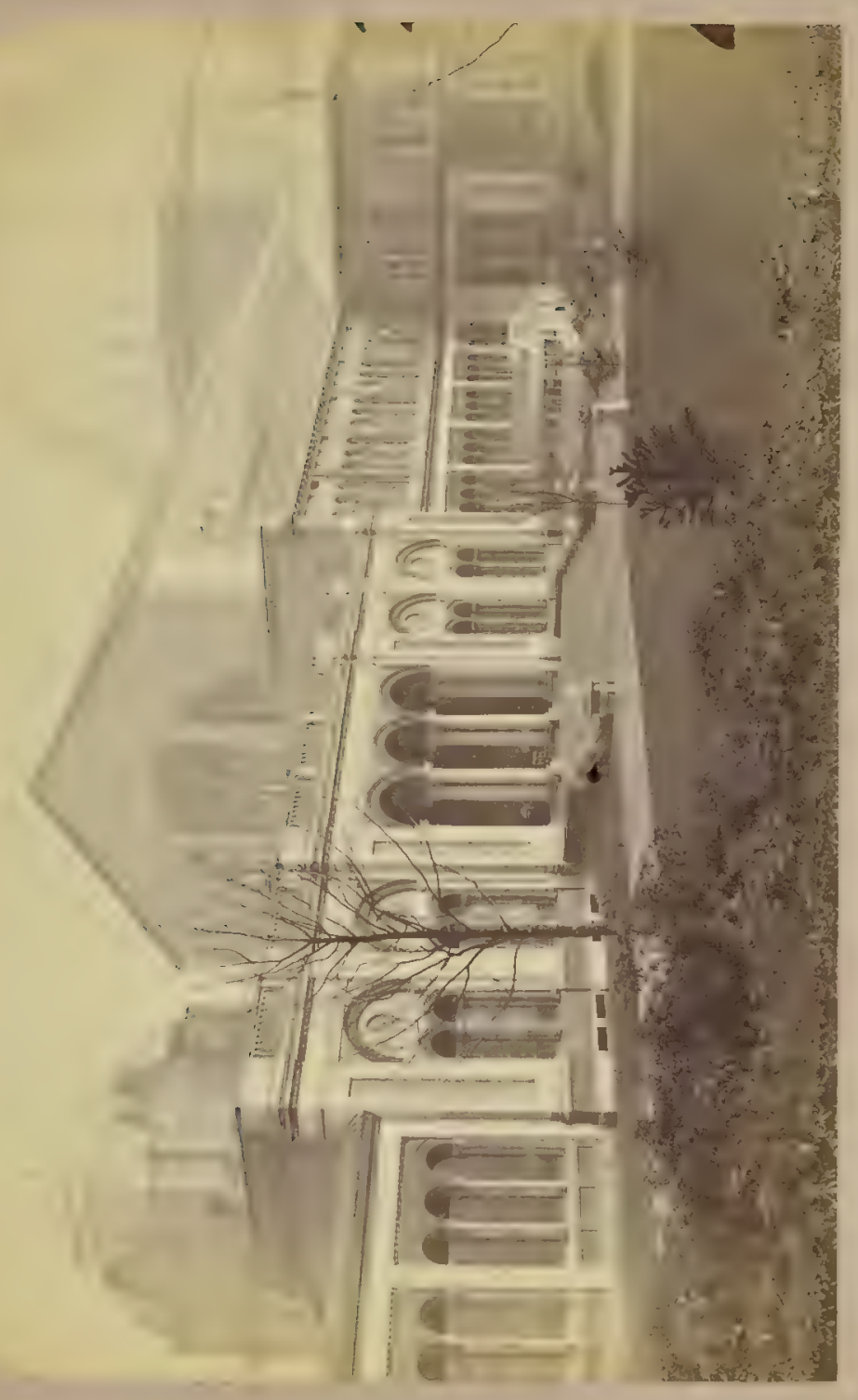





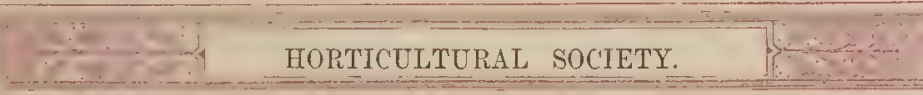

struction to the others is specially used for the purpose of heating these. It is fixed in the same stoke-hole, and close to those before described, but in no way connected with them. There is a main pipe leading from the top of the boiler, along the passage at the back, and beneath the gallery floor. This main is at equidistant points intercepted by the insertion of an extra-stout junction casting, which is employed for the purpose of connecting the ornamental pedestals fixed above the floor-line.

The quantity of piping in the Conservatory is about 9000 feet, in addition to various connections. The hot-water pipes beneath the ground-floor run in groups of 6,8 , and 10 respectively, in trenches varying from 2 feet to 3 feet wide, by about the same depth. On the level of the floor is a series of ormamental cast-iron gratings, through which the heated air ascends. These correspond to the gratings in other parts of the floor, through which the cooler air descends, and is conducted beneath each separate set of pipes. The gratings communicate directly with the circulating air-drains, and by this means the entire apparatus is kept in working order.

No dust, effluvium, or offensive vapour is generated by this apparatus: it produces perfect ventilation with uniform heat throughout the building, and for horticultural and other purposes it is commendable for its economy, its cleanliness, and its clurability.

The heating of the Conservatory has been executed loy Messrs. Weeks, of Chelsea, with whom several of the devices above mentioned originated. 


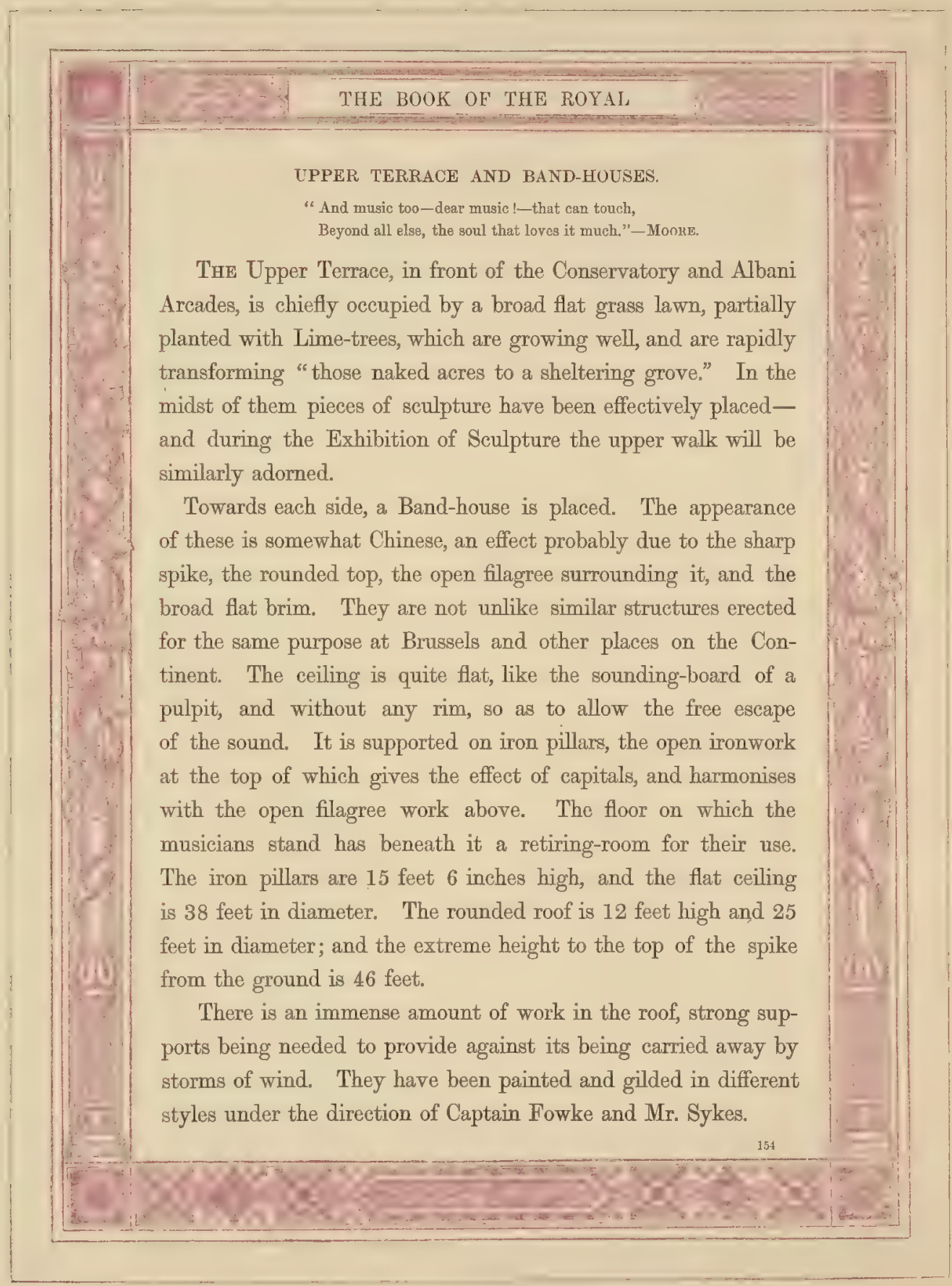




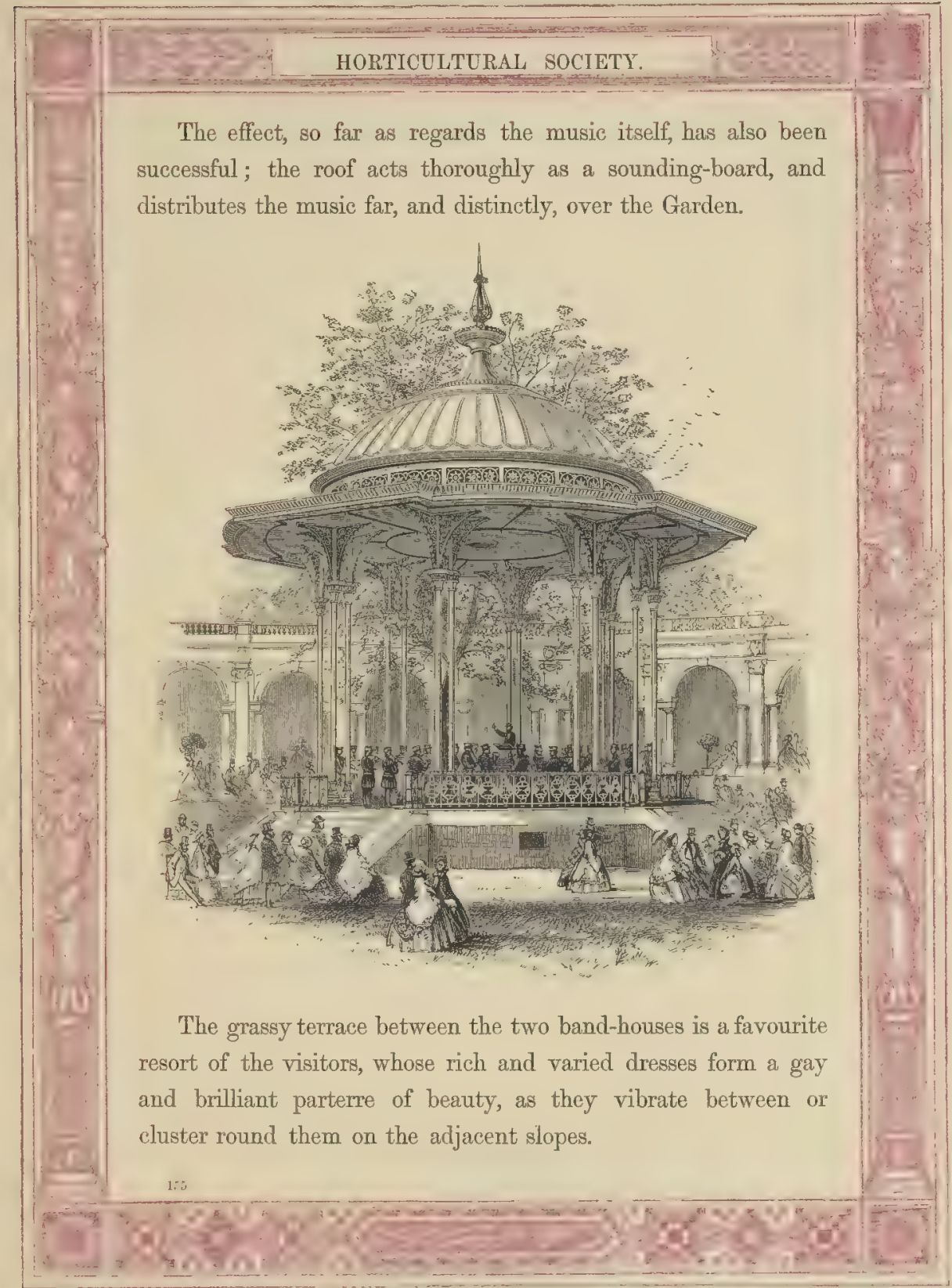




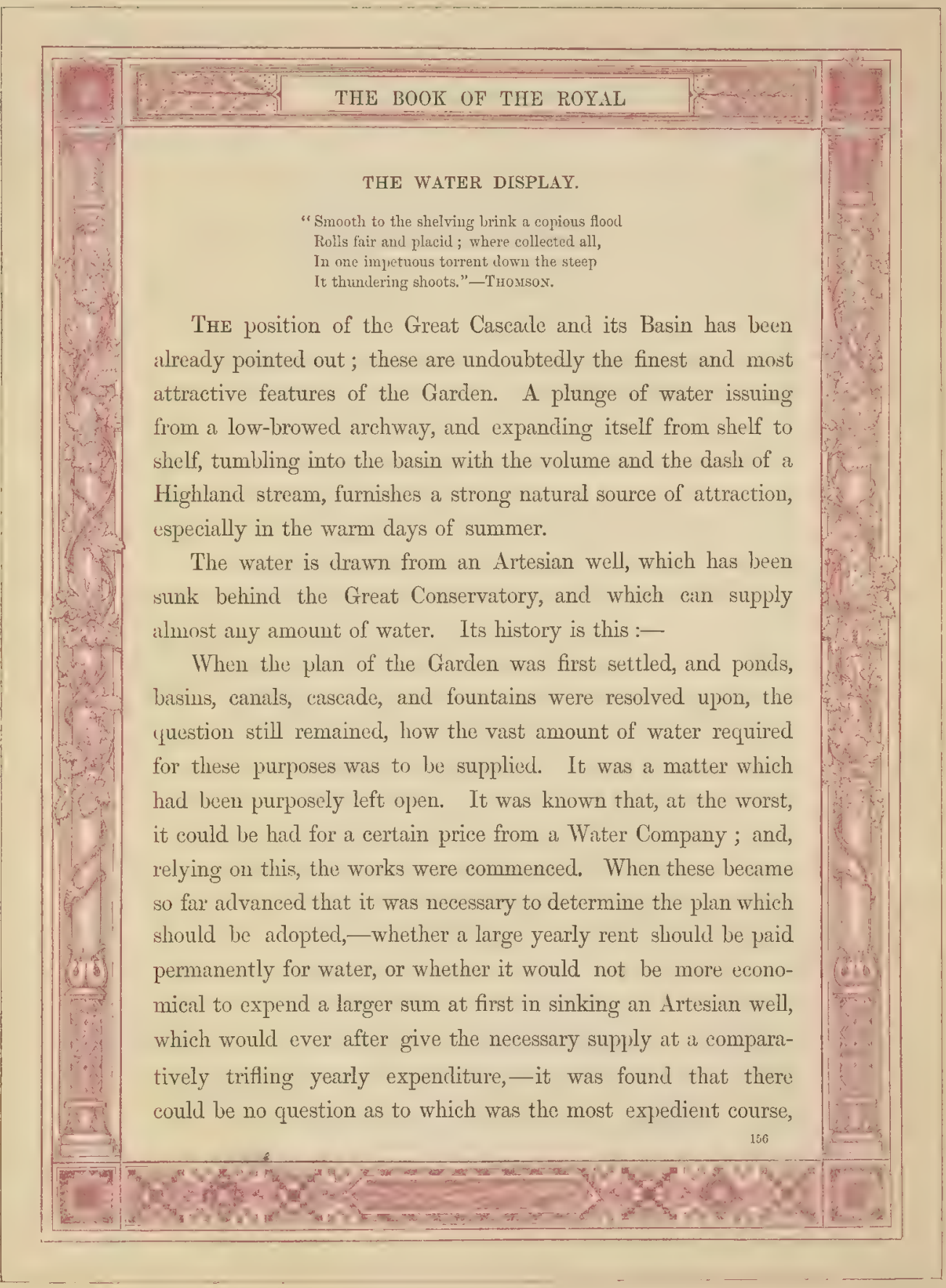




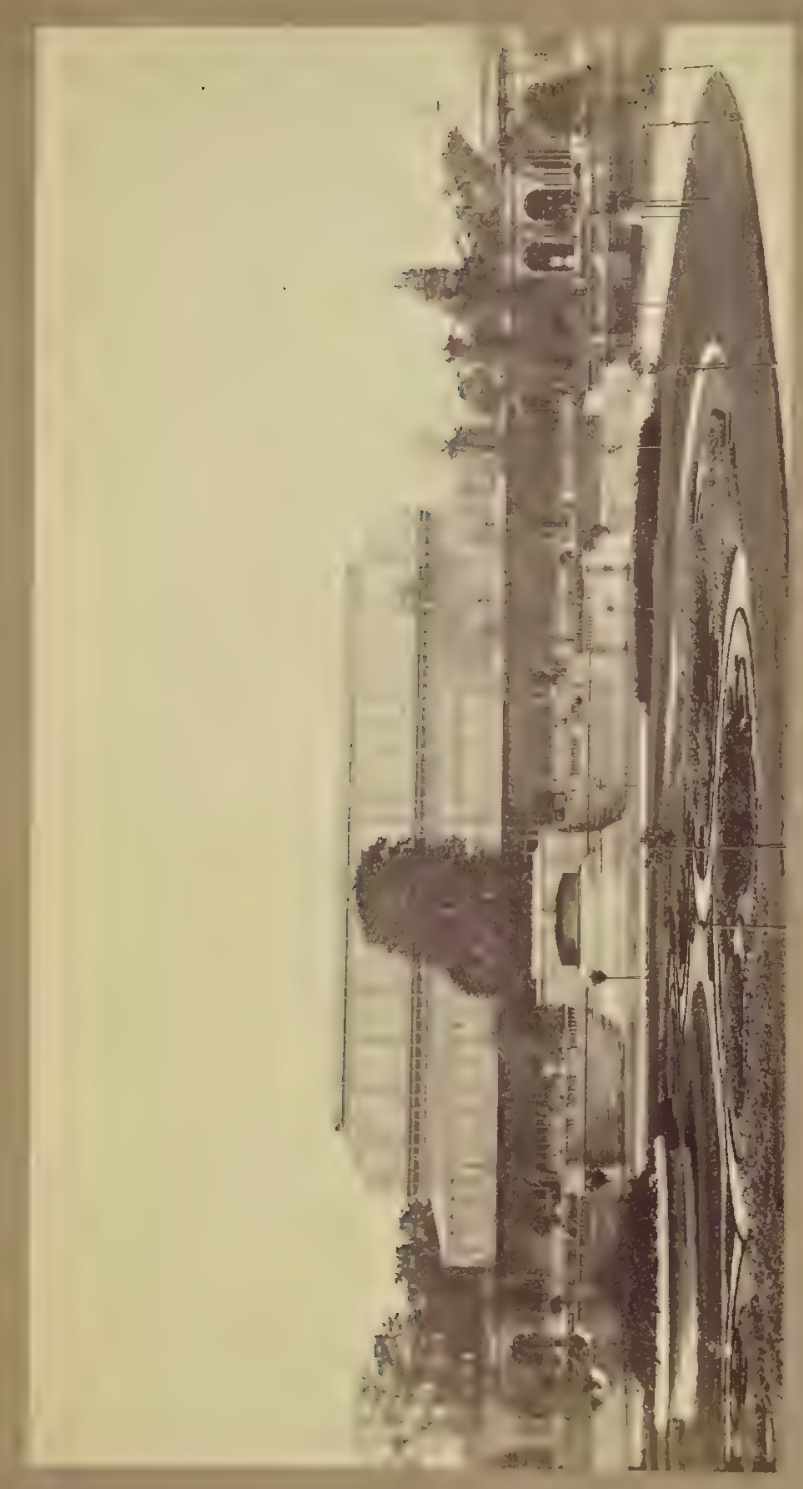





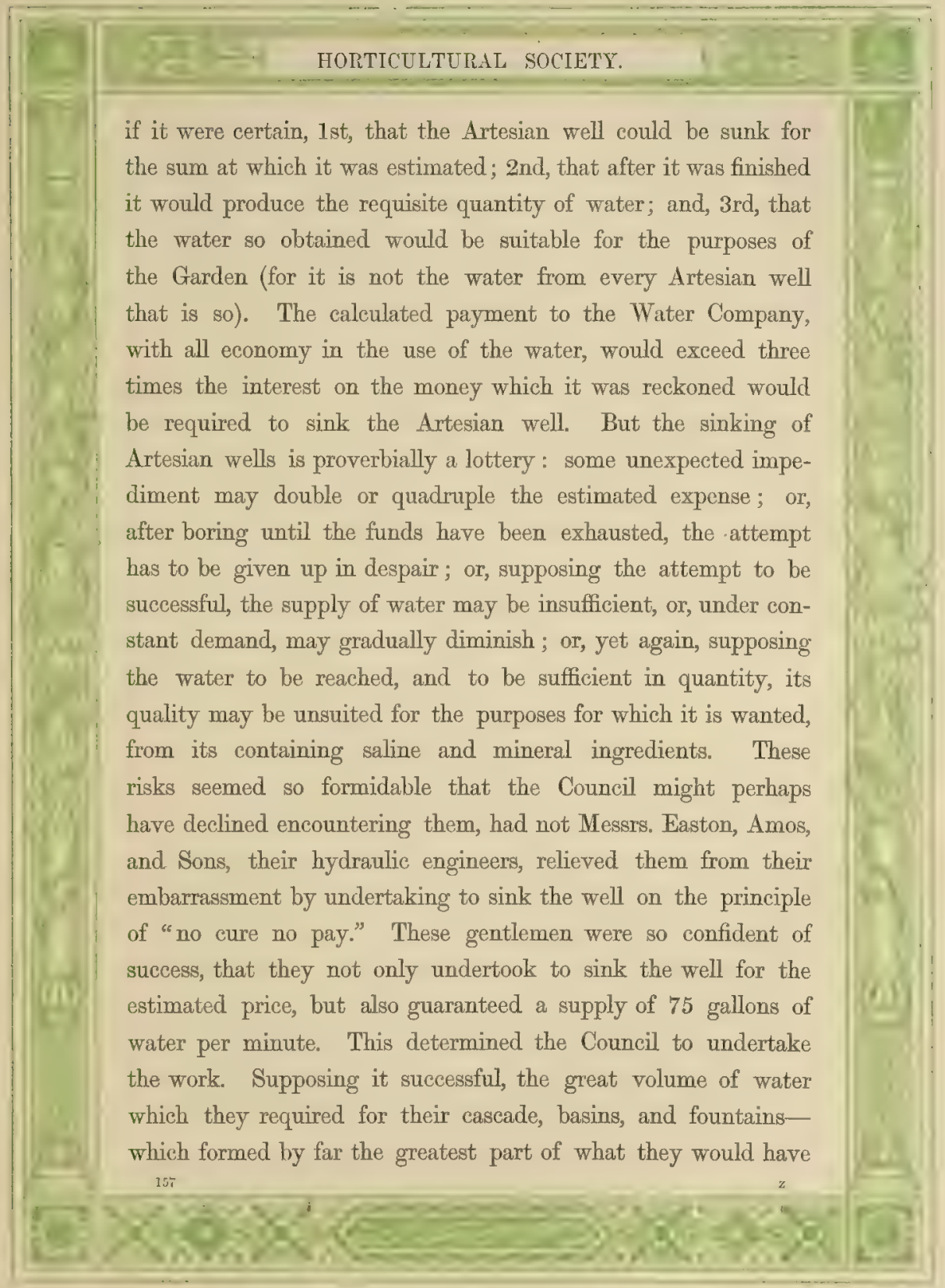


had to procure from the Water Company-would be supplied; and even although this water should turn out to be unfitted for gardening purposes, and it should be found necessary to oltain what was required for gardening from a Water Company, a large saving would still be effected by getting the main supply from the Artesian well.

The work has now been completed, the well bored; and the decision of the Council, as well as the confidence of the engineers, has been justified by the result. Not only has the well been sunk at the estimated cost, and water procured at the expected depth, but it has been found of the purest and softest quality, and in such abundance that, instead of supplying merely from 100,000 to 110,000 gallons in the 24 hours (the quantity stipulated for), it could readily supply a million gallons in that time if larger pumps and more powerful engines were employed. The total depth sunk and bored is 401 feet-a well having been sunk to the depth of 226 feet, and a bore thereafter carried down 175 feet farther.

The accompanying woodcut shows the nature and depth of the geological formations through which the well passed. For the sake of contrast, a similar cut of the Artesian well which supplies the Trafalgar Square fountains, the Palaces, and Public Offices, is placed alongside of it. The latter sketch, so far as the strata and their depths are concerned, very well represents the usual relations of these as found in numerous other Artesian wells which have been sunk in the London basin. It will be seen that the strata at the spot bored by the Socicty differ somewhat from the others - the London clay, especially, being found of much greater thickness than is usually the case. It would appear as if, in ancient days, the spot over which Kensington Gore now

1 is 


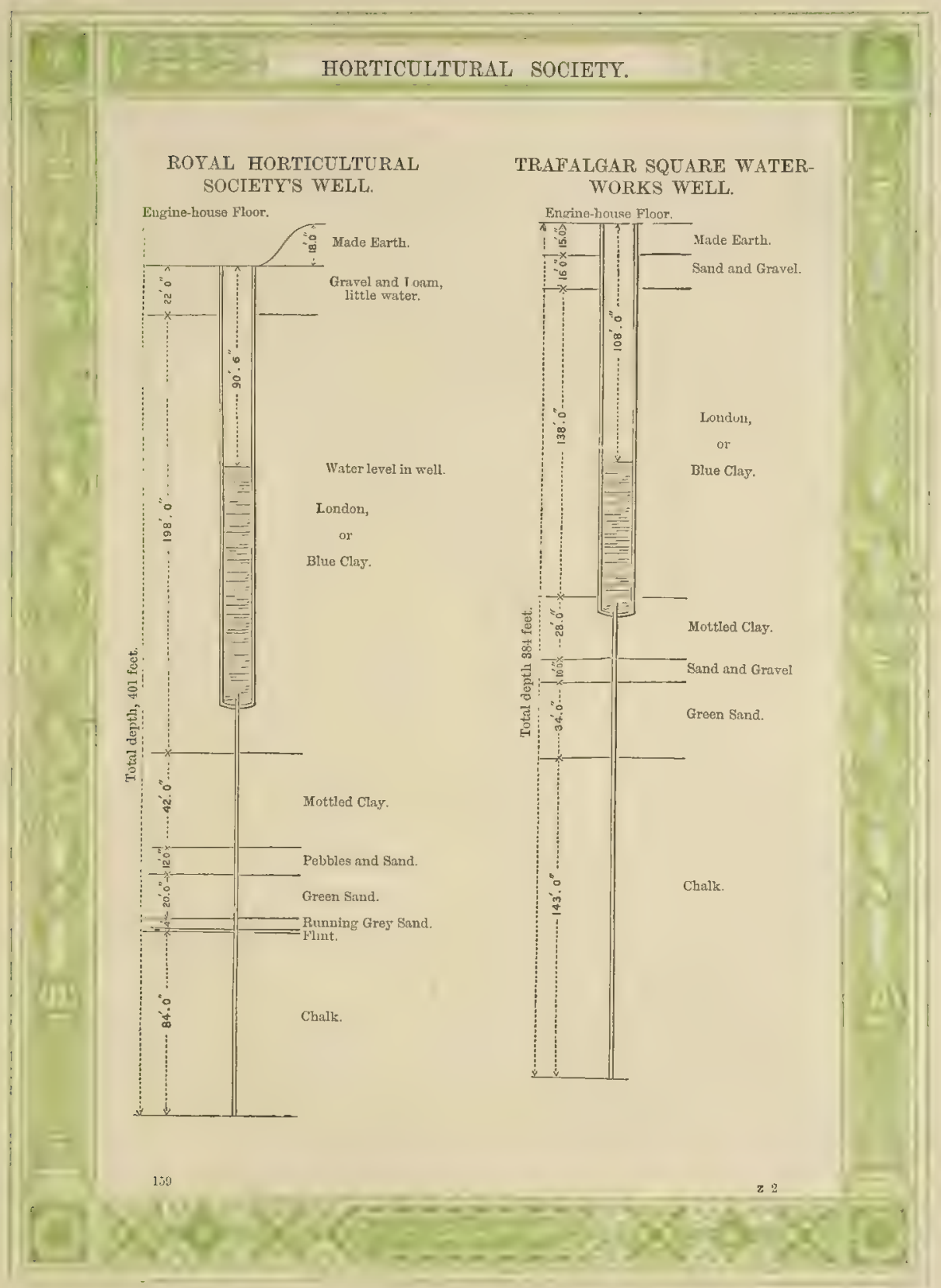


stands, had been one of the deep parts of the basin in which the London clay was being deposited. The two wells, however (that of Trafalgar Square and that of the Society), correspond in one point which is of excessively rare occurrence, wholly beyond provision, and a pure matter of chance: out of numerous wells bored by Messrs. Easton, Amos, \& Sons, for instance, these two are the only instances in which it has occurred. Whilst boring through the chalk, in both cases, the instrument came upon a fissure and dropped down a space of several feet. To understand the significance of this, it is necessary to remember that the manner in which the water in the chalk finds its way to the surface, or into the sea, is through such fissures. An example of its issuing at the surface from them may be seen in the river Wandle, which takes its rise at Carshalton, near Croydon, pouring out through such fissures a river ready made. An instance of its falling into the sea out of such fissures may be seen at low water near Brighton, where a succession of vertical fissures, from the narrowest chink to 6 inches wide, occurring at varying distances from each other, pours out an immense quantity of fresh water. Such fissures act as the main channels by which the water in the chalk finds its way to the sea. When a well sunk into the chalk does not fall upon one of these, it is dependent for water on what may pereolate through the surrounding chalk into the well; but if it light upon a fissure, its supply is drawn from a stream itself, and of course will depend upon the size of the stream how far it may be exhaustible. The quantity of water percolating through the chalk, however, is so great, that for all ordinary purposes, any well sunk for some depth in it is sufficient, if a very large supply is not wanted; the only draw- 


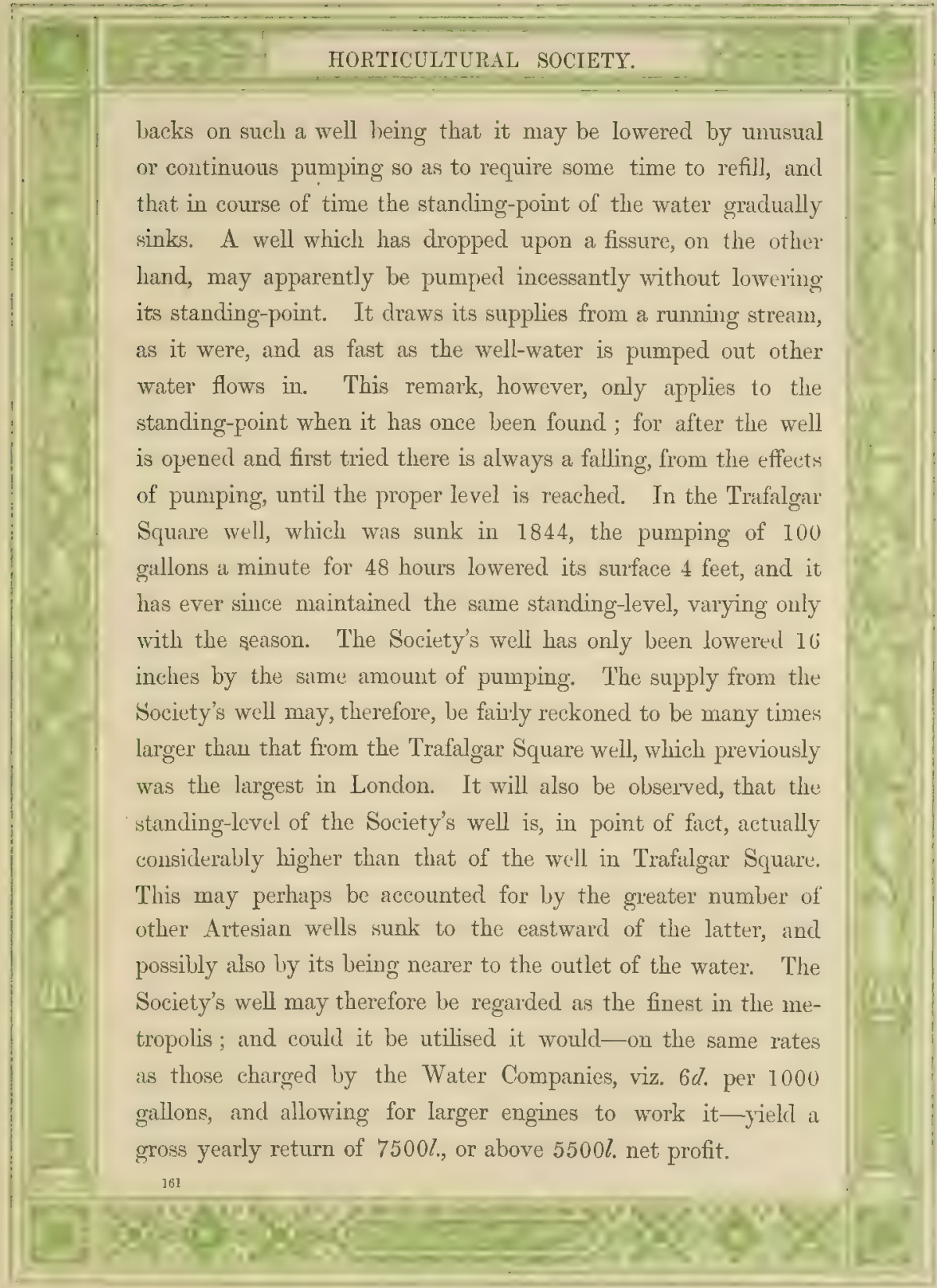


The water is pumped up from the Artesian well by a small engine in the back part of the Conservatory, which draws about 100 gallons in a minute, and empties it into the system of pipes or arteries by which all the basins and canals are connected together. Close beside the Artesian well, and also in the Conservatory, a powerful Appold pump is placed, connecting the two ends of these pipes together. When the whole of the pipes and basins are full, the Appold pump is set in motion. One condition of its doing its duty is, that these pipes and canals be full of water, as the pump has to set it in circulation, and, of course, unless they are full that cannot be done.

The principle of circulation is similar to that in our own bodies. One great aorta leads down to the reservoir, in the base of the Mentorial of the Exhibition of 1851, on each of the four sides of which there is a broad low arch, within which the water pours from the reservoir, forming four falls, facing respectively each quarter of the compass, North, East, West, and South. Issuing thus, in a mysterious way, under and within the archway, it is received by a basin which communicates with all these falls, and conducts the water to the front, where it pours itself in a fine sheet into a second large cup or basin, over the lip of which it falls in a still larger sheet into the great basin itself. The water in it flows over into pipes on each side-like the arteries leading to the limbs in the body-which pipes lead to the small basins between the canals. After receiving an addition there from the jets (worked separately and independently by the small engine), it overflows into a reservoir behind each basin, from which it again flows into a pipe emptying itself by a cascade into the canals. At the other end of these it over- 
flows into another reservoir, whence it is conducted in pipes back to a great culvert, the position of which may be known by a broad iron plate in the walk facing the Memorial on the south side of Mr. Nesfield's circular composition of gravel-beds in front of the great basin. This large culvert-up which a man might walk, and which, to continue the comparison of circulation, may be likened to the vena cava-receives all the water on its return from the four canals, and conveys it back to the Appold pump. That pump connects, or stands between, the two ends of the pipes, as the heart does between the veins and arteries, and, like it, draws the circulating fluid out of the one and throws it into the other. It does so by the excessively rapid revolution of a fan, which whirls the water round, exhausting it from the one pipe and forcing it into the other. By this means the whole of the garden waterworks are set in motion at once; and 5000 gallons are passed through the pump every minute. In two hours time it would exhaust the whole water in the canal and basins, which it takes the small engine four days and four nights constant working to fill. The ordinary purpose for which the Appold pump is used is merely to draw water out of one pipe; the forcing it into the other pipes is an additional application of the pump to another use.

The Appold pump is the work of one of those mechanical geniuses of whom England has produced more than any other nation. It is rather more than twelve years since, that Mr. Appold, on a visit to Cornwall, saw the steam cylinders which were being prepared there for the purpose of draining the Haarlem lake in Holland. These central steam cylinders, 12 feet in diameter, were to work several pumps around. One set 
of these pumps was to raise 250,000 gallons in a minute, and to discharge the contents only ten times in a minute. The waste of material and power struck him as excessive, and on the spur of the moment he declared that, with the fan working in Mr. Sim's neighbouring foundry at Redruth, he would undertake to pump up more water than could be done by all that immense apparatus in preparation. His friends disputed the possibility of its being so applied. He thought over it, and convinced himself that it could be done. He explainer his views to some of his engineering friends. They disputed them, and would not be convinced. Stimulated by this opposition and incredulity, he completed his plans, read a paper on the subject at the meeting of the British Association in Birmingham, and exhibited his pump in operation at the Exhibition in 1851. Had Mr. Appold chosen to patent his discovery he might have realised a large fortune from it, but, with characteristic liberality, he presented it to the nation. The beauty and simplicity, power and economy, of the contrivance have carried all before it, and pumps on this principle are now gradually spreading over the whole world.*

* Mr. Appold's mechanical genius applies itself with equal success to the most trifling household contrivance as to the most important plans of engineering. The Society protited from this in a trifle-which, however, may be repeaterl, in illustration of the readiness and fertility of his resources. On one occasion when he visited the Garden, one of the large panes of plate-glass in the heavy front doors at the entrance had just been broken. The day had been stormy, and the wind eatching one of the doors, which had been left open by a visitor, slammed it to with such violence that the glass-pane was shattered in pieces. The same nisfortune had happened before, and the precautions taken to prevent its recurrence having proved insufficient, Mr. Appold found the officers puzzling over the problem of how to prevent an open door slamming-to. He at once solved the problem for them. A bellows, inside a box, was placed over 


\section{HORTICULTURAL SOCIETY}

The central basin is well stocked with large carp and goldfish. Her Majesty most kindly supplied forty-four fine carp from Virginia Water : a few of the largest, weighing from 8 lbs. to 10lbs., must be of great age (perhaps not less than 100 years old), and have become grey and hoar with years. Some have spawned, and the basin literally swarms with young fish. They are fed daily between three and four o'clock, there not yet being a sufficiency of other food in these mudless waters. As yet, the mode of feeding practised at Fontainebleau has not been adopted. For many years, as narrated in a periodical of the day, the petting of the carp there has been a favourite pastime. Maids of honour and other ladies relieve the ennui of court-life by watching and feeding these fish from the windows of the palace, the walls of which are washed on one side by the lake; and now-a-days there are women who make a business of selling bread to visitors for the latter purpose. But they would have little amusement for their money if they threw in ordinary bread. Big carp have an enormous appetite; soft penny rolls, being mere mouthfuls, disappear with ostrich-like celerity. So, to prevent the immediate disappearance of these bonnes bouches, bread in the form of large balls is baked until it becomes as hard as biscuit, and with these balls the carp are regaled. When one is cast upon the water, it gives an idea of the enormous carp population of the lake. As soon as the bread touches the surface it is surrounded by hundreds of these fish, which dart

the door, to the top of which was fastened a peg placed upright and so arranged that, when the door was being elosed-to, the peg pressed against the bellows, and meeting with resistance offered by the air within, absolutely prevented any violence whatever in the shutting-to. 
from all parts of the lake to the object of attraction. Then, conscious, apparently, of their inability to crush the extremely hard balls, the carp combine with wonderful unanimity to guide the bread to that part of the lake bounded by the wall, and when there commence to butt at it, until, by repeated blows and the softening effect of the water, the ball is made to yield and open. Then is to be seen another curious sight. While shoals of carp have been pounding away at the bread-ball, preparing it for eating, some dozen monsters hover about, apparently indifferent to what is passing near them. But no sooner is the bread ready for swallowing, than one among these giants, probably the tyrant of the lake, rushing to the prize, cleaving his way through the swarm of smaller carp, and shouldering them to the right and left, seizes the bread with open jaws, between which it quickly disappears.*

Parallel to the Milanese Arcades, on each side of the Garden, are two oblong canals at a lower level than the surrounding ground. Their continuity is interrupted by a platform higher than their level, but a little lower than that of these arcades, and a small basin on the platform on each side supplies a cascade, which (on the same plan as that of the large cascade) flows out of a semicircular arch. A flat slab rests on the stonework over

* By-and-by similar scenes may be seen in the basin in the Horticultural Garden. The fish, during the summer of 1862, had become sufficiently familiar to appear regularly at the dinner hour at the spot where their food is distributed. During the following winter they disappeared, doubtless into the darkest and warmest of the culverts; but with the warm days of spring they have again appeared, leaping and throwing themselves out of the water.

"Nor undelighted by the boundless Spring

Are the broad monsters of the foaming deep;

From the deep ooze and gelid cavern roused,

They flounce and tumble in unwieldy joy."-THомsos. 


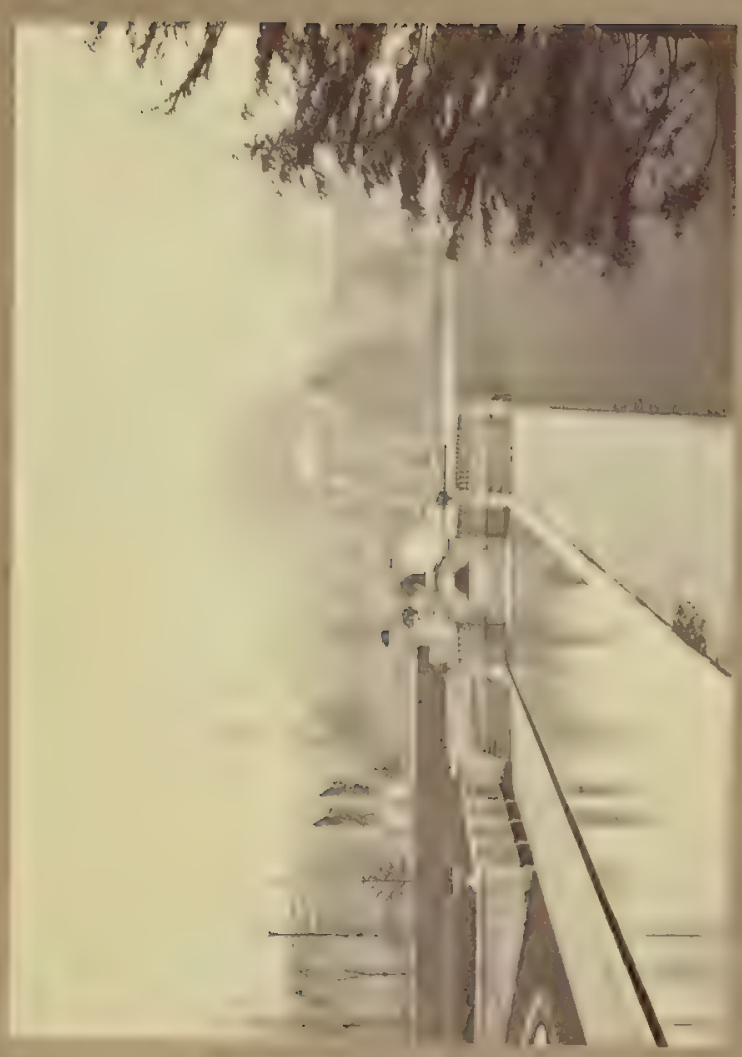


$\left\{\begin{array}{l}1 \\ 1\end{array}\right.$ 


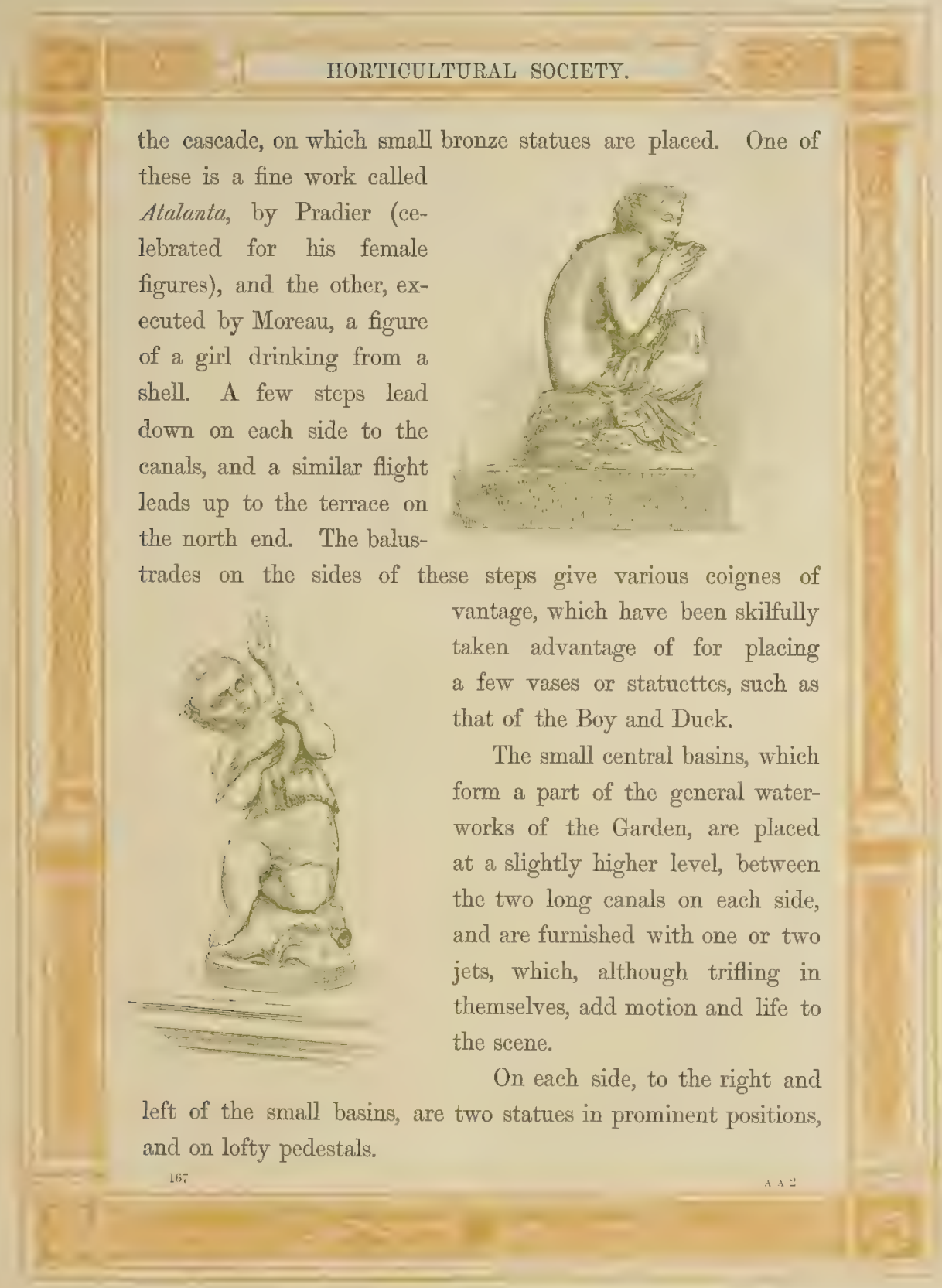




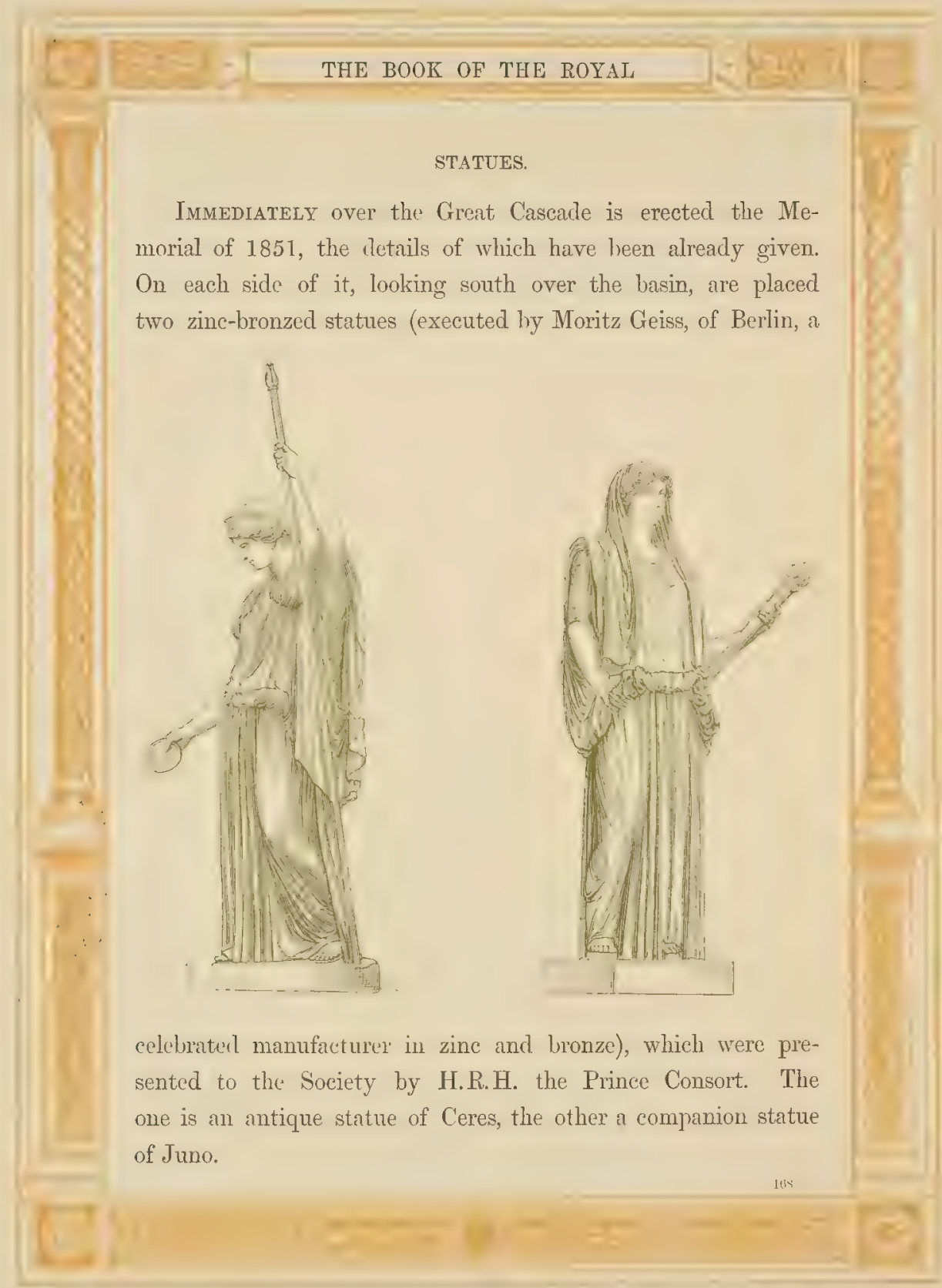




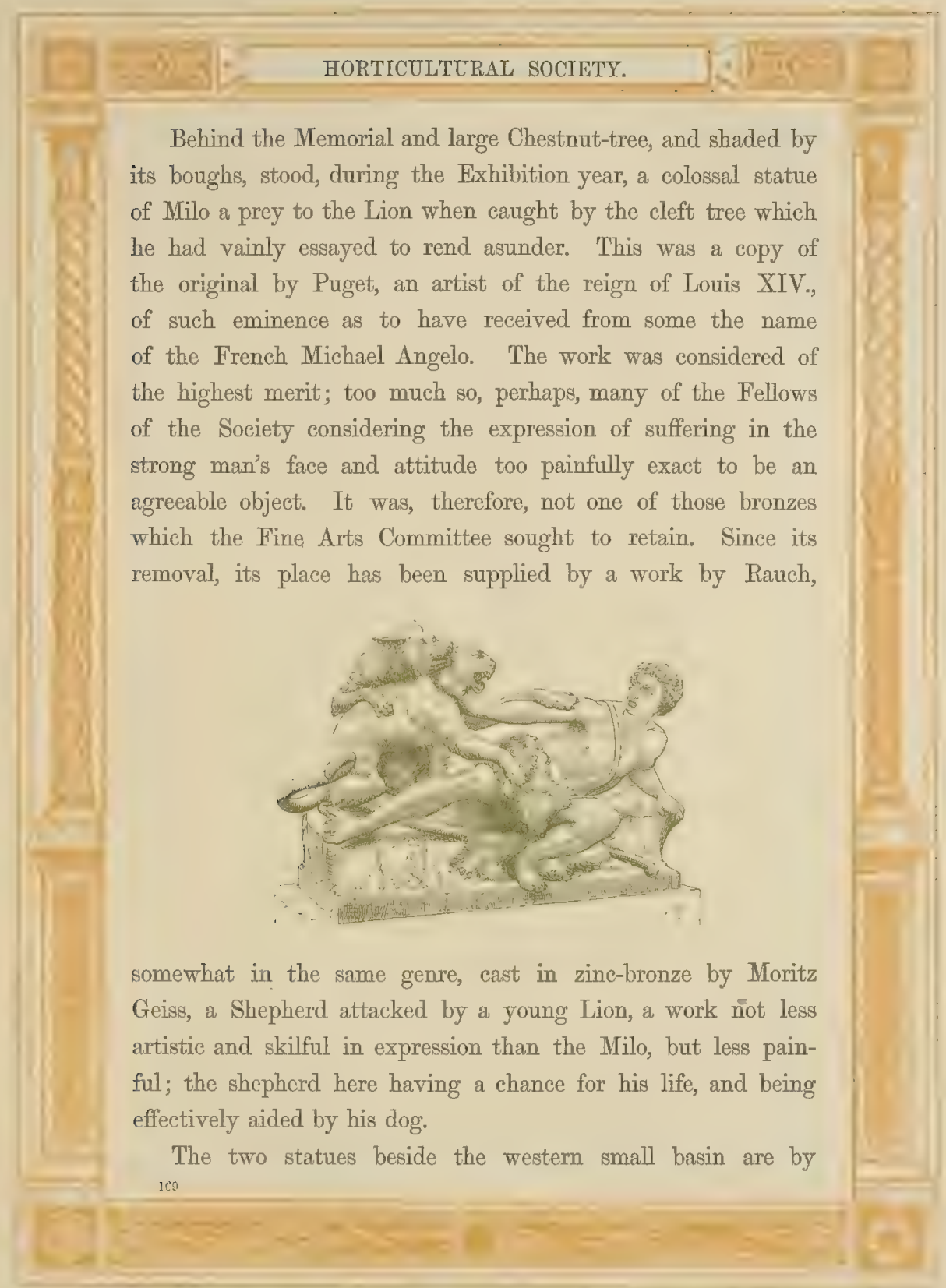


Rauch. This celebrated German sculptor was employed by the late King of Bavaria to execute six statues of Victory, in different attitudes, for the hall of the Walhalla at Ratisbon, where they are now placed: no easy task, as may be imagined. The fertility of the artist's genius, however, proved equal to the demand made upon it, and six statues, of great beauty, and varied in attitude, were executed by him. With a liberality seldom practised by those who purchase works of fine art for themselves, His Majesty the King of Bavaria allowed easts of these statues to be taken; and the Society, at the recom-

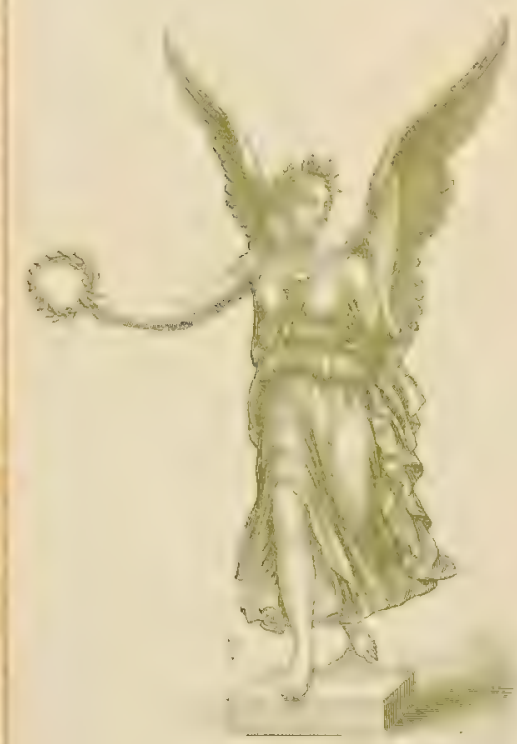
mendation of H.R.H. the Prince Consort, purchased two of them, cast in zincbronze, by Moritz Geiss. They are nine feet high, and have been placed behind the central basin on the west side instead of on the east side (which would have been preferred), on account of the protection the arcade on that side affords against the western blast, to which the halfexpanded wings of the Victories offer rather too much hold. They occupy a very effective position, their wings breaking the even outlines of the tops of the arcades, which form the horizon from 


\section{HORTICULTURAL SOCIETY.}

almost any point of view which the spectator can select. When these statues were being placed upon their pedestals, we accidentally overheard the remarks of the workmen employed in the work, and the criticism of one of them struck us as remarkably good :- "I like that one best; she is coming heartily forward, as if there was no doubt about it; the other one is holding her wreath half back, as if she had not quite made up her mind."

The statues beside the small basin on the east side are copies in zinc-bronze from the originals, of the well-known statues of Urania (in the Louvre), and the Vénus d'Arles.

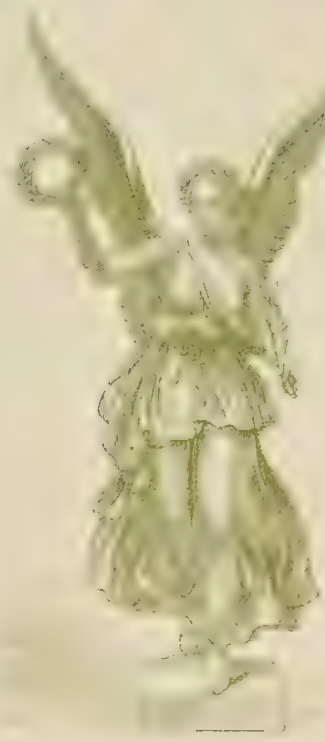

\section{RIBBON BEDS AND COLOURED GRAVELS.}

"And what a wilderness of flowers! It seem'd as though from all the bowers And fairest fields of all the year,

The mingled spoil were gathered here." - Moore

THERE are a good many (some think too many) examples of coloured gravel and ribbon beds in the Garden.

In the first place, we have four beds composed entirely of coloured gravels and Box, without any intermixture of bedding- 
out plants. They lie on the sloping glacis stretching up from the side of each of the four canals, and are designed so as to represent natural objects, such as the Rose, the Thistle, the Shamrock, and the Leek.

The gravels of which they are composed are as follow, viz. :-

White Derbyshire spar, for the white.

Blue John, or purple fluor spar, for the purple.

Welsh slate, for the pale blue.

Pounded red brick, for the red.

Pounded yellow brick, for the yellow.

Mixtures of the two last, for a lighter red or a darker yellow.

Fragments of coloured glass, uniform or mixed, for various other colours, which are less liberally distributed.

In addition to these, besides other small plots, mainly used as coloured walks or frames in which plants are set, there are seven large compartments in which the coloured gravel beds or paths form only portions of the compartments, and are intended to relieve their barrenness of flowers in winter, and combine with them in summer. To our taste the best of these are four beds, two on each side, on the level in front of the Milanese Arcades. These are traced in a continuous geometrical design, as a twisted ribbon or succession of circles, similar to designs, if not the same, as seen executed in marble on the floors of some of the churches in Italy.

The three larger composite beds are, -a circular one to the south of the central basin, and a triangular one on each side of the middle walk. These are enclosed in an edging of artificial 


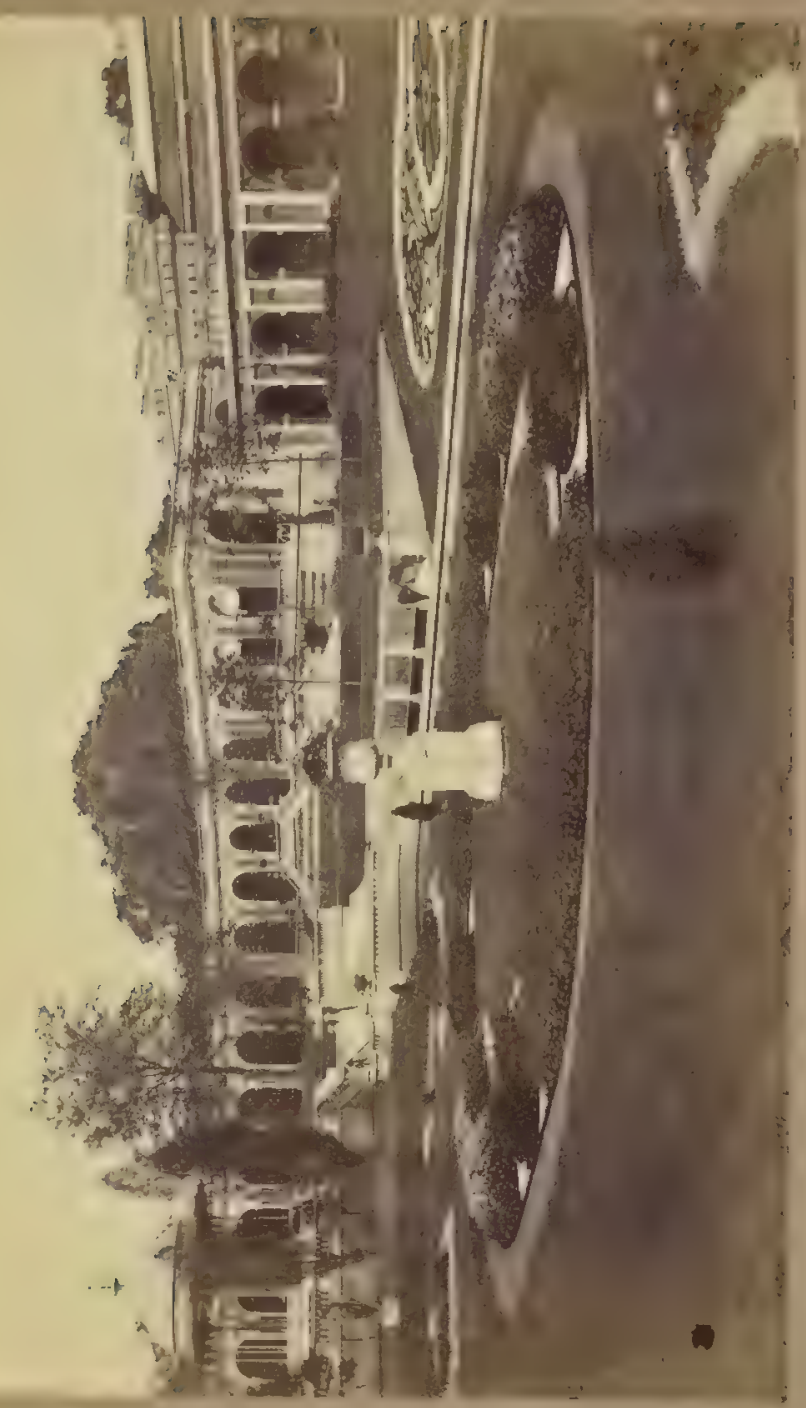




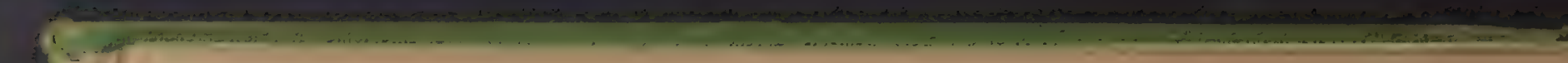




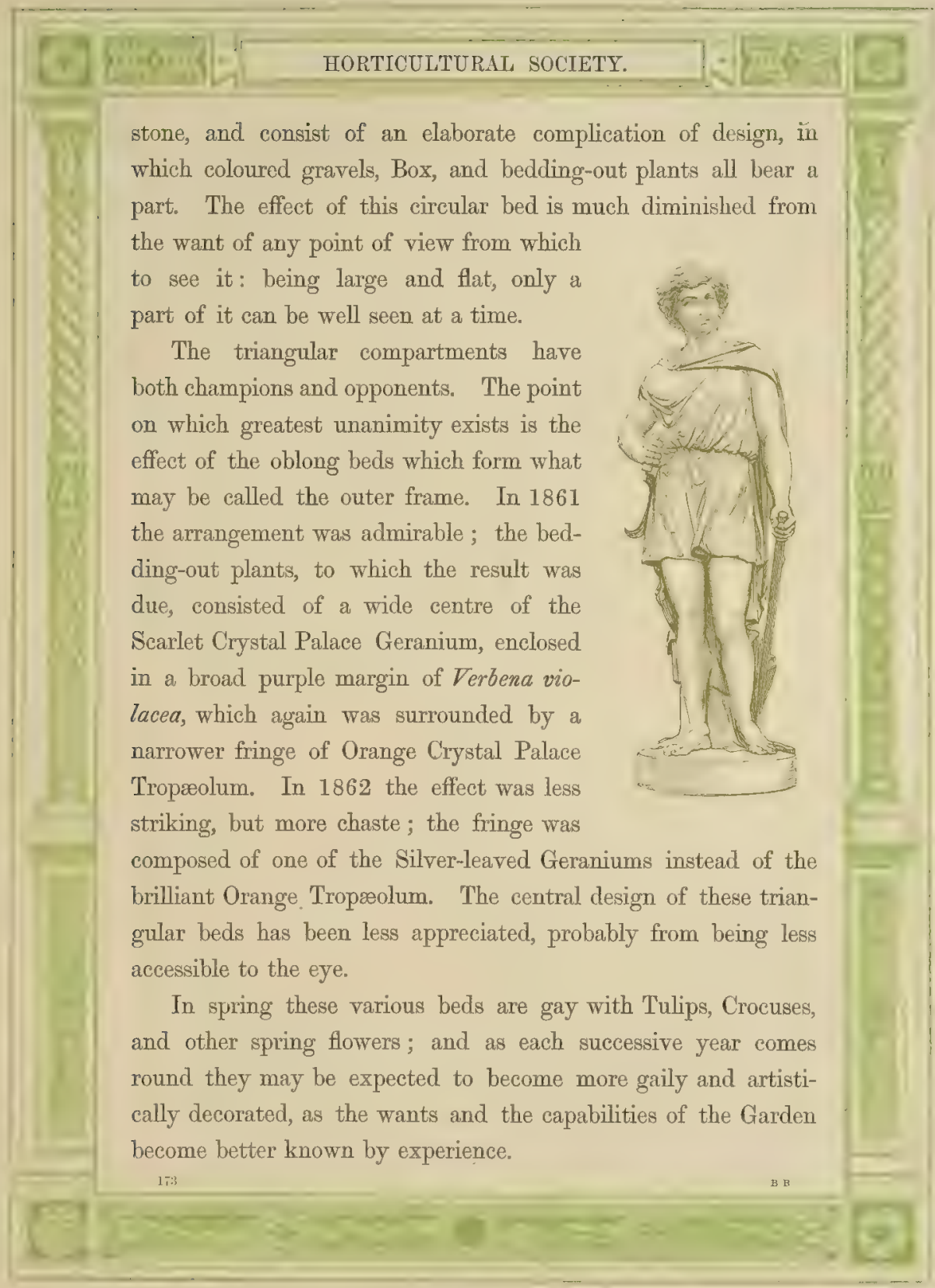





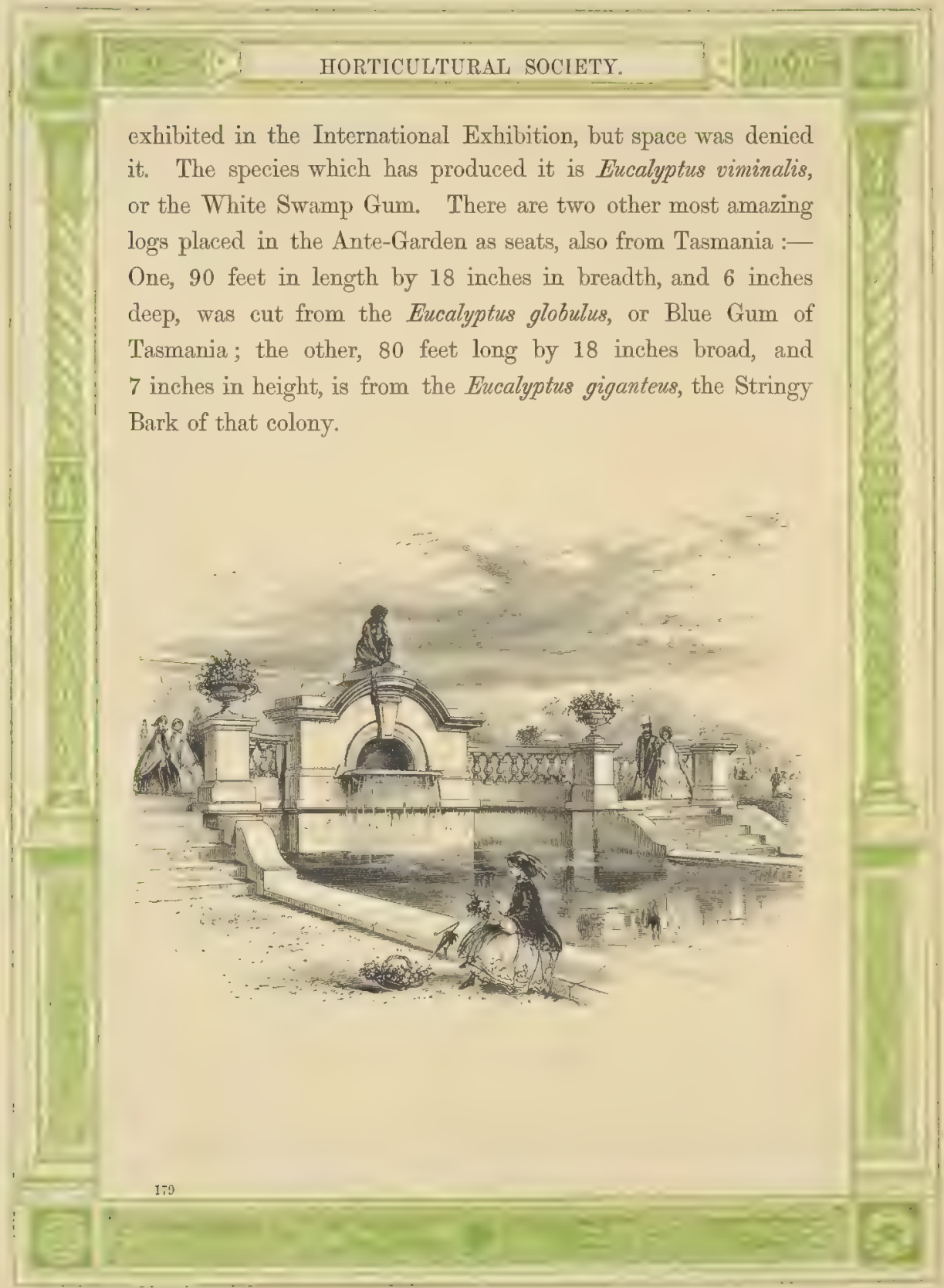




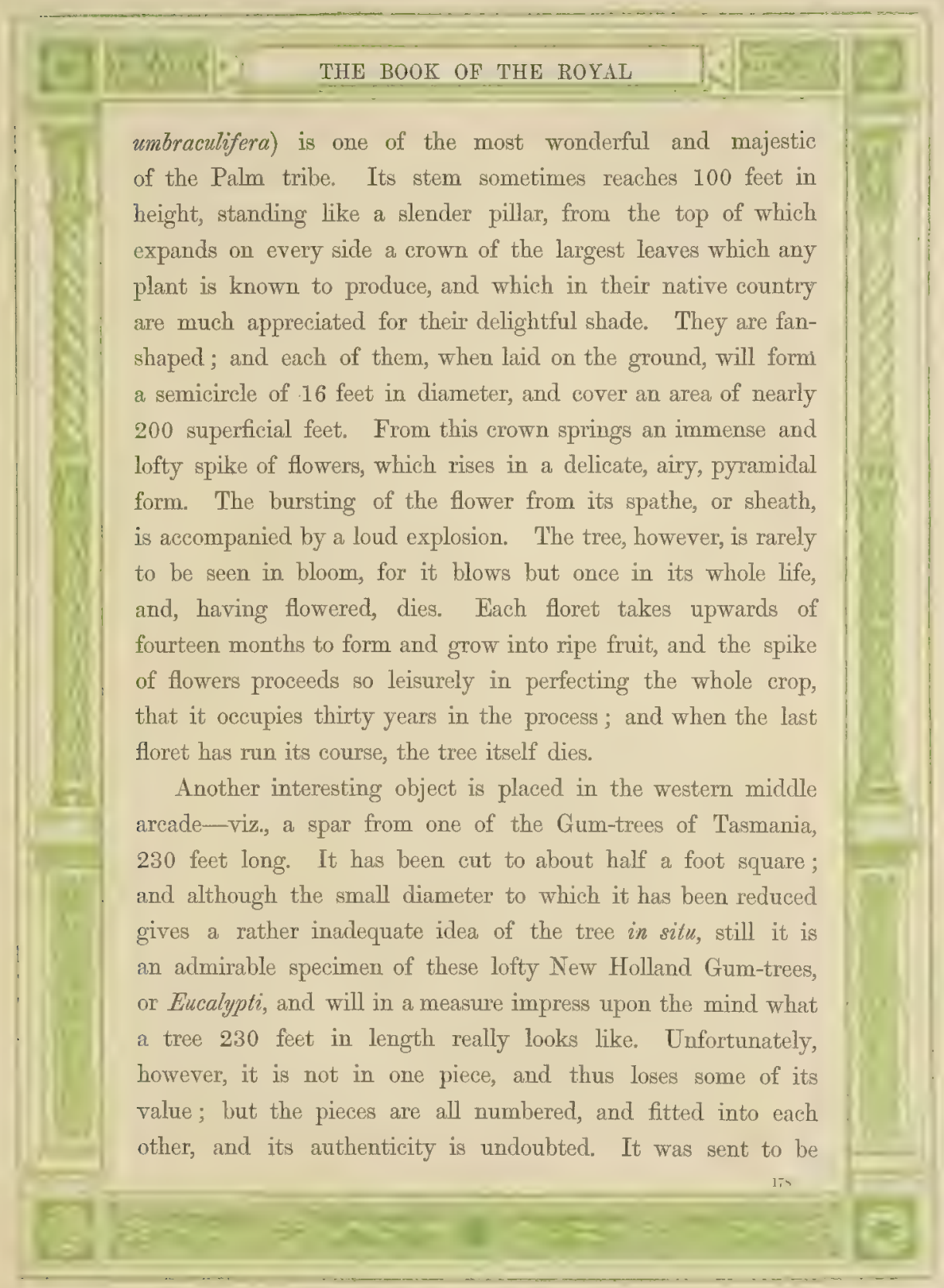




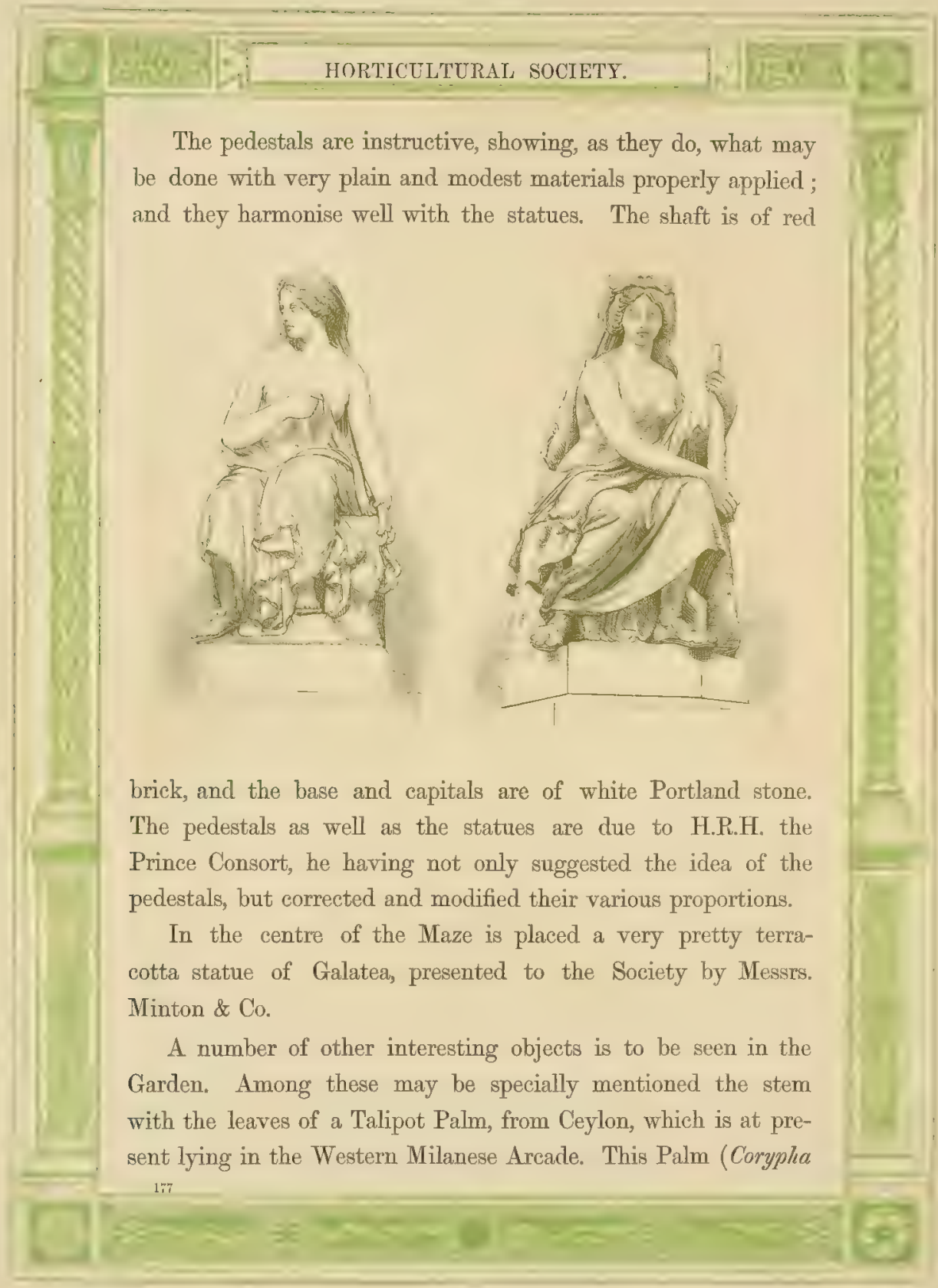




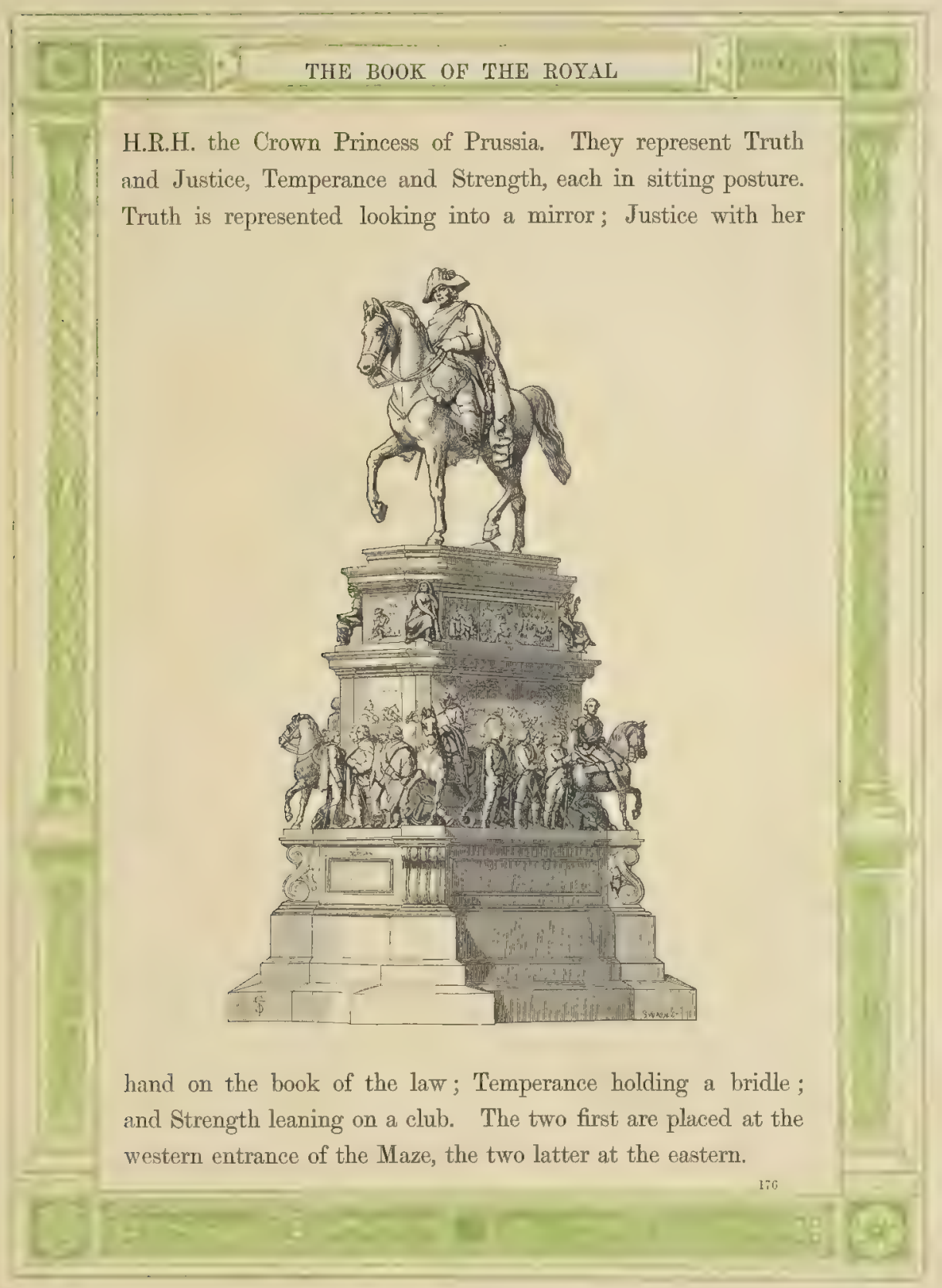




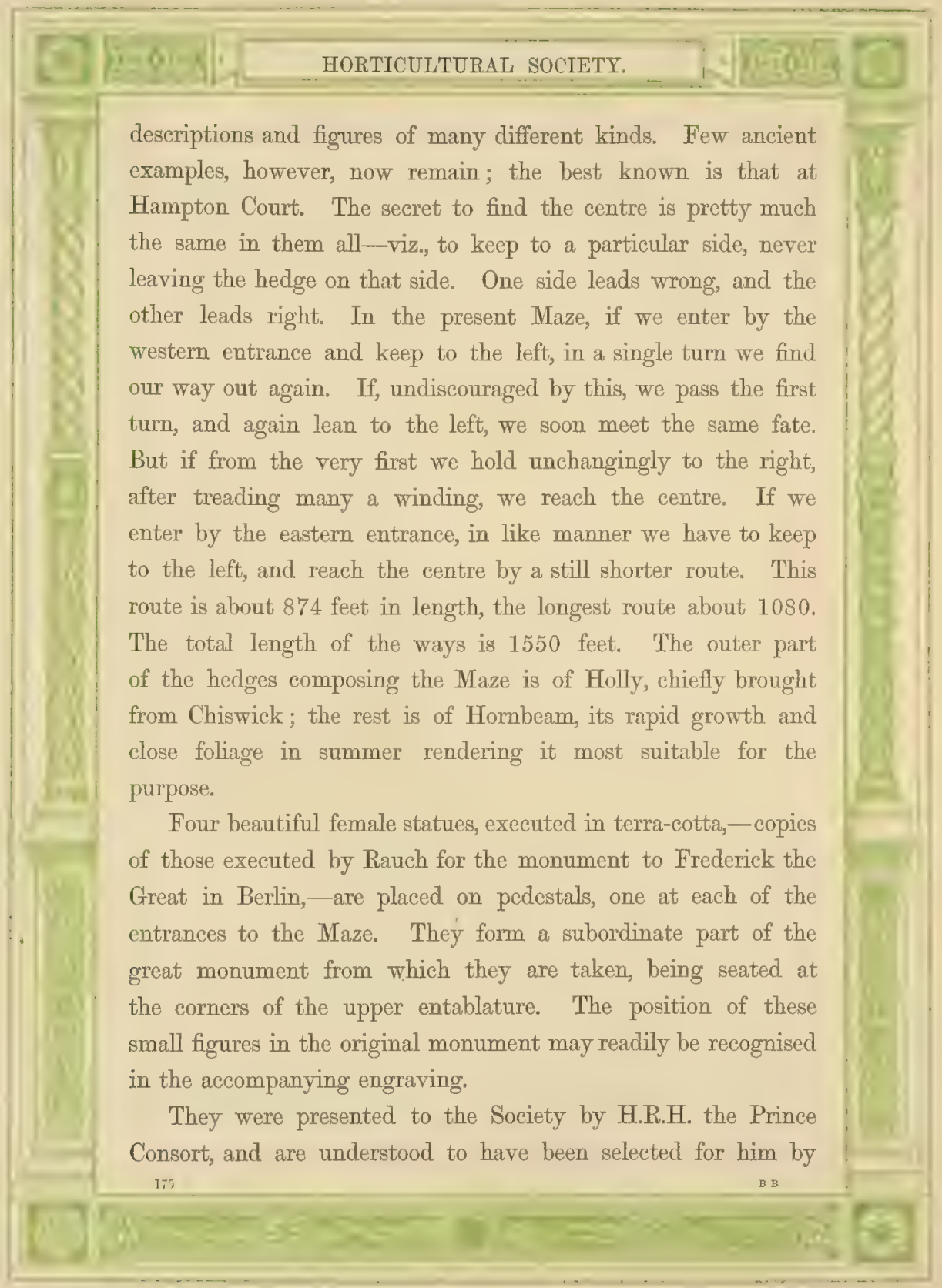




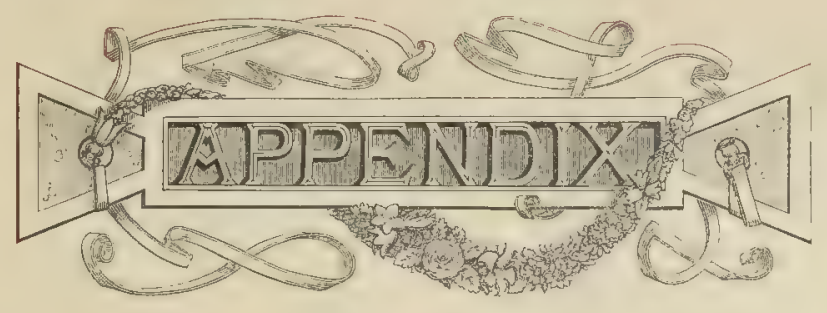

\section{I. - CORRESPONDENCE BETWEEN MR. WEDGWOOD AND SIR JOSEPII BANKS, RELATIVE TO THE ESTABLISHMENT OF THE HORTICULTURAL SOCIETY.}

\section{DEAR SIR,}

Etrutia, Jume 29, 1801.

I HAVE been turning my attention to the formation of a Horticultural Society, and have drawn up such heads as have appeared to me necessary for the first formation of the Society. It would be proper to add a preamble, just stating the ideas of the first founders of the Society, and intimating that we wish to clash with no society at present instituted whose plans are different from ours. By this means we shall give no offence to any party. By not binding ourselves to publish annually we shall not be obliged to expose ourselves to the world in an imperfect state by publishing papers not worth making public. When you have read the enclosed, I shall be happy to have your opinion on it.

I expect to be in London about the middle of July, and I hope you will have so settled your plans that you will be able to give me your company at Coote when I leave town the middle of August. I mention it to you now, that you may have time to arrange your affairs, that I may not be disappointed again. When you come again, I hope you will make some stay with me.

There is now a fine opportunity to try any experiments on trees, but nobody to do it. My stay is so uncertain that I have not begun to do anything, for $I$ could nothing effectually, as I must do every individual thing with my own hands. My direction now is Etruria, Staffordshire.

Believe me ever Yours Truly,

$$
\text { JOHN WEDGWOOD. }
$$

P.S. If you should see Sir Joseph Banks, will you be so good as to ask him 


\section{APPENDIX.}

his opinion of the plan, and learn how far we might have a chance of having his patronage of the scheme.

\section{W. Forsyth, Esq.,}

Royal Gardens, Kensington.

That a Society be formed to be called "The Horticultural Society."

That the object of this Society shall be to collect every information respecting the culture and treatment of all plants and trees, as well culinary as ornamental.

That every new member shall be balloted after a Society of original members has been formed, and that every such member at his admission shall pay one guinea besides his annual subscription.

That a certain number of honorary members may be elected, who shall be admitted to the sittings of the Society without paying any subscriptions; that two black balls be sufficient to reject such honorary candidate.

That the Society shall from time to time publish a volume of papers of the same size and form as the Transactions of the Adelphi Society, and that each member shall be entitled to a copy, but no honorary member unless he has furnished a paper judged worthy of publication.

That the Society shall annually choose a President, four Vice-Presidents, a Committee of Inspection, and a Secretary.

That the Committee shall have the power of selecting the papers for publication, and that no paper shall be published before it has been read at a sitting of the Society.

That no paper shall be published which does not treat of horticultural subjects.

That it shall be considered within the intention of this Society to give premiums for improvements in horticulture, whenever it shall be judged expedient so to do.

SIR,

SoHo SQUARE, July 31, 1801.

I RETURN with this, Mr. Wedgwood's letter, and his plan for an Horticultural Society. I approve very much of the idea: I know of no trade that conceals so many valuable branches of knowledge as that of a gardener, and few subjects where the public will be more benefited by the disclosures which such a society will immediately occasion. I shall be flattered if the gentlemen who are to arrange the plan do me the honour to set me down as an original member.

I am, Sir, Your very Humble Servant, JOHN WEDGWOOD.

W. ForsYTH, Esq.,

Royal Gardens, Kensington. 


\section{ORIGINAL MEMBERS OF THE SOCIETY.}

\section{II.-LIST OF ORIGINAT MEMBERS OF THE SOCIETY.}

The Marquess of Exeter.

$$
\text { " } \quad \text { Blandford. }
$$

The Earl of Dartmouth.

$$
\text { " Coventry. }
$$

Lord Cawdor.

$$
\text { "Seaforth. }
$$

The Right Hon. Sir Joseph Banks, Bart. Sir Robert Preston, Bart.

Dr. Jas. Edw. Smith.

"Lettsom.

"Anderson.

"Sims.

The Right Hon. Chas. Greville.

The Hon. R. F. Greville.

The Rev. John Grove Spurgeon.

$$
\text { " John Lloyd. }
$$

Messrs. W. T. Aiton.

$$
\text { , J. T. Aiton, }
$$

"James Anderson.

, John Bell.

" Wm. Corbett.

"Geo. Caswall

" Samuel Pepys Cockrell.

", James Dickson.

, P. Delafield.

" Wm. Forsyth.

" Wm. Forsyth, Jun.

, Thos. Forsyth.
Messrs. George Griffiths.

', John Hunneman.

,J John Hall.

, A. H. Haworth.

, George Hibbert.

, John Hawkins.

"Thos, Andrew Knight.

"Witshed Keen.

" A. B. Lambert.

"Wm. Meyers.

" Alex. Malcolm.

" Chas. Miller.

" John Maitland.

" John Leigh Philips.

, John Passingham.

"Wm. Price.

Thos. Poole.

"William Rashleigh.

"William Radley,

" R. A. Salisbury.

", William Salisbury.

"Geo. Sedley,

"Harry Stoe.

"James Stephens.

, Dawson Turner.

, John Trovelyan.

", Wm. Vaughan.

, James Vere.

, John Wedgwood.

The names of Lord Seaforth and Thos, Andrew Knight are not mentioned in the minutes of March 28, from which this list is taken; but it would appear from an entry on April 11, that it had been intended to include them. 


\section{III.-LIST OF OFFICE-BEARERS AND MEMBERS OF COUNOIL SINCE THE FORMATION OF THE SOCIETY.}

$1804-5$.

Earl of Dartmouth, President.

Rt. Hon. Sir Jos. Banks, Bart., K.B., James Diekson,

Rt. Hon. Chas. Greville,

Richard Anthony Salisbury,

James Sims, M.D.,

John Wedgwood, Treasurer,

Rev. Alexander Cleeve, Secretary.

Wm. Townsend Aiton, Sir Wm, Blizzard.

Rt. Hon. Isaac Corry. Wm. Forsyth.

Sir Christopher Hawkins, Bart.

John Hawkins. Thoras Hoy.

Lord Midileton.

Charles Miller.

William Meyers.

William Price

James Vere.

$$
1805-6 .
$$

Earl of Dartmonth, President.

Rt. Hon. Sir Jos. Banks, Bart., K. B,

James Dickson,

Rt. Hon. Chas, Greville,

Rich. Anthony Salisbury, Secretary, Presidents.

James Sims, M. D,

John Wedgwood, Treasurer,

Wm. Townsend Aiton. Sir Wm. Blizzard.

George Caswell

Wm. Forsyth.

Earl of Coventry.

John Hawkins.

Sir Chris. Hawkins.

Thomas Hoy.

lmer Bourke Lambert. William Meyers.

Charles Miller.

H. Ronalds,

Jolnn Trevelyan.

\section{6-7.}

Earl of Dartmouth, President.

Rt. Hon. Sir Jos. Banks, Bart, K.B., James Dickson,

Rt. Hon. Chas, Greville, Treasurer, Vice-

Rieh. Anthony Salisbury, Secrehary, Presidents.

James Sims, M.D.,

John Wedgwood,

W. T. Aiton.

George Caswell?

Wm. Forsyth.

Thoinas Hoy.

Charles Miller.

Earl Powis.
James Anderson.

Earl of Coventry.

Sir Chris. Hawkins.

T. Andrew Knight.

William Minier.

H. Ronalds.
$1807-8$.

Earl of Dartmouth, K.G., President.

R.t. Hon. Sir Jos, Banks, Bart., K. B, James Diekson,

Rt. Hon. Chas, Greville, Treasibrer, Vice-

Rich. Authony Salisbury, Secretary, Presidents.

James Sims, M.D.

John Wedgwood,

W. T. Aiton.

William Corbett.

William Forsyth.

A. H. Haworth.

T. A. Knight.

William Minier.

W. Smith.

James Anderson.

John Elliot.

Sir Chris. Hawkins

Thomas Hoy.

Charles Miller.

Earl Powis.

D. P. Watts.

$$
\text { 1808-9. }
$$

Earl of Dartmonth, President.

Rt. Hon. Sir Jos. Banks, Bart., K.B.,

James Dickson,

Rt. Hon. Chas. Greville, Treasurer, Vice.

Rich. Anthony Salisbury, Secretary, Presidents. James Sims, M.D.,

John Wedgwood,

W. T. Aiton.

Marquis of Blandford. George Caswell.

Thomas Hoy.

John Elliot.

Charles Miller

Earl Powis.

William Smith.

T. A. Knight.

William Minier.

Lord Selsey.

D. P. Watts

John Trevelyan.

Bishop of Winchester:

1809-10.

Earl of Dartmouth, President. James Dickson,

Rt. Hon. Charles Greville, Vice-Presidents. Charles Miller,

John Eilliat, Treasurerem. $\int$

Richard Anthony Salisbury, Secretary.

W. T. Aiton.

Rt. Hon. Sir Joseph Banks, Bart.

T. Hoy. Thomas Andrew Knight,

Earl Powis. Lord Selsey.

William Smith. John Trevelyøn.

Bishop of Winchester. 


\section{OFFICE-BEARERS AND MEMBERS OF COUNCIL.}

$1810-11$.

Earl of Dartmouth, President.

James Dickson,

Sir Chris. Hawkins, Bart., , Fiec-Presidents.

Charles Miller,

John Elliot, Treasurer,

Richard Anthony Salisbury, Secretary.

W. T. Aiton.

R. Hon. Sir Juseph Banks, Bart.

Right Hon. Lord Dundas.

II. Grimston.

T. Hoy.

William Minier.

Lord Selsey.

William Smith. Bishop of Winchester.

$$
1811-12 .
$$

Thomas Andrew Knight, President,

James Dickson,

Sir Chris. Hawkins, Bart.,

Charles Miller,

John Elliot, Treasurer,

Richard Anthony Salisbury, Secretary.

Rt. Hon. Sir Joseph Banks, Bart.

John Bell.

Right Hon. Lord Dundas.

H. Grimston.

T. Hoy.

Roger Pettiward,

William Smith.

Thomas Reynolds. Bishop of Winchester.

$$
1812-13 .
$$

Thomas Andrew Knight, President.

Rt. Hon. Sir Jos. Banks, Bart.,

James Dickson,

Vive-

Sir Chris. Hawkins, Bart,

John Elliot, Treasurer,

Presidents.

Richard Anthony Salisbury, Secretary.

George Anderson.

John Bell.

Right Hon. Isord Dundas.

H. Grimston.

T. Hoy.

Roger Pettiward.

Thomas Reynolds.

Joseph Sahine. Roger Wilbraham.
$1813-14$.

Thomas Andrew Knight, President.

Rt. Hon. Sir Jos, Banks, Bart.,

James Dickson,

Sir Chris. Hawkins, Bart., Y Presidents.

John Elliot, Treasurer,

Richard Anthony Salisbury, Secretary.

George Anderson.

William Anderson.

Anthony Carlisle.

John Cresswell.

Right Hon. Lord Dundas.

Roger Pettiward.

Thomas Reynolds.

Joseph Sabine. Roger Wilbraham.

$1814-15$

Thomas Andrew Knight, Prasident.

James Dickson,

John Elliot, Treasurer, Yice-Presidents.

Joseph Sabine,

Roger Wilbraham,

Richard Anthony Salisbury, Secrotory.

George Anderson.

William Anderson.

Sir Joseph Banks, Bart.

A. Carlisle.

John Cresswell.

Thomas Cuffe

John Maher.

George Henry Noehden. Roger Pettiward.

$1815-16$.

Thomas Andrew Knight, President.

James Dickson,

Joseph Sabine,

Roger Wilbraham, Vice-Presidents.

John Elliot, Treasurer,

Richard Anthony Salisbury, Secretary.

William Anderson.

Sir Joseph Banks, Bart., K. B.

Anthony Carlisle.

John Cresswell.

William Dickinson.

Joseph Kirk.

John Maher.

Roger Pettiward. Thumas Reynolds. 


\section{APPENDIX}

$$
1816-17 .
$$

Thomas Andrew Knight, President.

John Cresswell,

James Dickson,

John Elliot, Treasurer,

Roger Wilbralıam,

Joseph Sabine, Secratary.

Thomas Hare, A ssistont-Secretary.

George Anderson.

William Anderson.

John Braddick.

Right Hon. Lord Dundas.

Joseph Kirke.

Roger Pettiward.

Thomas Reynolds. Richard Anthony Selisbury.

$$
1817-18 .
$$

Thomas Andrew Knight, President.

John Cresswell,

James Dickson,

John Elliot, Treasurer,

Vice-Presidents

Roger Wilbraham,

Joseph Sabine, Secretary.

Thomas Hare, Assistant-Secretary.

George Henry Noehden, Vice-Secretary.

John Braddick.

Joseph Kirke.

William Malcolm.

George, Earl of Mountnorris.

Roger Pettiward.

Thomas Reynolds. Alexander Seton.

$$
1818-19 .
$$

Thomas Andrew Knight, President.

John Cresswell

James Dickson,

Johu Elliot, Treasurer,

Roger Wilbraham,

Joseph Sabine, Secretary.

Vice-Presidents

Thomas Hare, Vice-Secretary, August, 1819.*

Geo. Henry Noehden, Vice-Sec., May, 1819.*

John Braddick.

Alez. MacLeay.

William Malcolm.

Sir O, Moseley.

Earl of Mount Norris.

Hugh Ronalds.

Richard Anthony Salisbury. Alexander Seton.

- Dr. Noebden resigned 17th August, in consequence of going abroad, and Mr. MacLeay was elected member of Council in his piace, and MIL. Hare to thll the offlec of Vice Seeretary
$1819-20$.

Thomas Andrew Knight, President.

John Cresswell,

James Dickson,

John Elliot, Treasurer,

Roger Wilbraham,

Joseph Sabine, Secretary.

Thomas Hare, Vice-Secrelary.

Alexander MacLeay.

William Maleolm. John Motteux.

George Henry Noehden, elected 18 Jan, 1820.

Thomas Reynolds, *

Hugh Ronalds. Richard Anthony Salisbury. Claude Scott. Alexander Seton.

- Replaced, on his death, by George Henry Yoehden.

$$
1820-21 .
$$

Thomas Andrew Knight, President.

James Dickson,

John Elliot, Treasurer,

John Motteux,

Roger Wilbraham,

Joseph Sabine, Secretary.

George Henry Noehden, Fíce-Secretary.

Edward Barnard.

John Cresswell.

Thomas Hare.

George Loddiges.

Sir Charles Long.

Alexander MacLeay.

William Malcolm. Claude Scott.

$$
1821-22 \text {. }
$$

Thomas Andrew Knight, President.

James Dickson,

John Elliot, Treasurer,

Claude Scott,

Vice-Presidents

Roger Wilbraham,

Joseph Sabine, Secretary.

George Henry Noehden, Tice-Secretary.

Edward Barnard.

George Loddiges.

Sir Charles Long.

Alexander MacLeay.

John Motteux.

Richard Anthony Salisbury.

Alexander Seton. John Walker. 


\section{OFFICE-BEARERS AND MEMBERS OF COUNCIL.}

$$
\text { 1822-23. }
$$

Thomas Andrew Knight, President.

James Dickson,

John Elliot, Treasurer, Vice-Presidents.

Alezander MacLeay,

Sir Claude Scott,

Joseph Sabine, Secretary.

Edward Barnard, Vice-Secretary.

The Earl of Aberdeen.

William Griffin.

Robert Henry Jenkinson.

George Henry Noehden.

Hugh Ronalds.

Richard Anthony Salisbury.

Alexander Seton. John Walker:

$$
1823-24 .
$$

Thomas Andrew Knight, President.

The Earl of Aberdeen,

John Elliot, Treasurer,

Alexander MacLeay,

Vice-Presidents.

John Walker,

Joseph Sabine, Secretary.

Edward Barnard, Vice-Secretary.

Samuel Brookes.

Alexander Henderson.

Charles Holford.

Robert Henry Jenkinson.

Joseph Kirke.

Hugh Ronalds.

Sir Claude Scott. Alexander Seton.

$$
1824-25 .
$$

Thomas Andrew Knight, President.

The Earl of Aberdeen,

John Elliot, Treasurer,

Robert Henry Jenkinson,

John Walker, and after his deatl

Alexander MacLeay,

Joseph Sabine, Secretary.

Edward Barnard, Vice-Secretary.

Samuel Brookes.

Henry Moreton Dyer.

Alexander Henderson, M.D.

Charles Holford.

Joseph Kirke.

George Loddiges.

Richard Anthony Salisbury. Sir Claude Scott.
$1825-26$.

Thomas Andrew Knight, President.

The Earl of Aberdeen,

John Eilliot, Treasurer,

Alexander Henderson, M. D., Vice-Presidents

Robert Henry Jenkinson,

Joseph Sabine, Secretary.

Edward, Barnard, Vice-Secretary.

The Duke of Bedford.

Samuel Brookes.

Charles Holford.

George Loddiges.

Richard Anthony Salisbury.

Sir Claude Scott.

Alexander Seton. James Young.

$$
1826-27 .
$$

Thomas Andrew Knight, President.

Duke of Bedford,

$\left.\begin{array}{l}\text { John Elliot, Treasurer, } \\ \text { Alexander Henderson, M.D., }\end{array}\right\}$ Fice-Presilents.

Robert Henry Jenkinson,

Joseph Sabine, Secretary.

Edward Barnard, Vice-Secretary.

Earl of Aberdeen.

William Thomas Brande.

John Lee.

George Loddiges.

Sir Claudo Seott.

Alexander Seton.

Comte de Vandes. James Young.

$$
1827-28 .
$$

Thomas Andrew Knight, President.

John Elliot, Treasurer,

Alexander Henderson, M.D., Vice-Presiden/s.

Robert Henry Jenkinson,

Sir Claude Scott,

Joseph Sabine, Secretary.

Edward Barnard.

Duke of Bedford.

Heary Moreton Dyer.

Right Hon. William Huskisson.

John Lee.

William Malcolm.

Alexander Seton.

Comte de Vardes. James Young.

187 


\section{$1828-29$.}

Thomas Andrew Knight, President.

Henry Moreton Dyer,

John Elliot, Treasurer, *

Alexander Henderson, M.D.,

Robert Henry Jenkinson,

Joseph Sabine, Secretary.

Edward Barnard.

John Lee.

George Loddiges,

William Malcolm.

Roger Pettiward.

The Marquess of Salisbury. Sir Claude Scott. Alexander Seton.

\section{Comte de Vandes.}

- Replaced, on his resignation, Dec. 9th, 1828, in consequence of ill-health, by Mrr. R. FT, Jenkinson, as Treasurer.

$$
\text { 1829-30. }
$$

Thomas Andrew Knight, President.

Henry Moreton Dyer,

Alexander Henderson, M.D., Vice-Presidents. R. H. Jenkinson, $\uparrow$ Treasurer,

Joseph Sabine, Secretary. $\uparrow$

Edward Barnard.

Earl of Dartmouth.

Thomas Hoblyn.

John Lee.

George Loddiges.

Roger Pettiward. +

William Malcolm.

4 Resigned March 16th, and repliged on Apri1 6 th by - George Bentharn, Richard Rligh, The Earl of Carnarpon, Peter Grant, and Willam Harrison.

$$
1830-31 .
$$

Thomas Andrew Knight, President.

Edward Barnard,

Earl of Carnarron,

Henry Moreton Dyer, Vice-Presidents.

Alexander Henderson, M. D.,

Alexander Seton, Treasurer.

George Bentham, Secretary.

Richard Bligh.

Peter Grant.

William Harrison.

John Alexander Henderson.

Thomas Hill.

John Lee.

George Loddiges. Nicholas Aylward Vigors.

$$
1831-32 .
$$

Thomas Andrew Knight, President.

Edward Barnard,

The Earl of Carnarvon,

Heary Moreton Dyer,

Alexander Henderson, M.D.,

Alexander Seton, Treasurer.

George Bentham, Secretary.

Richard Bligh.

N. W. Ridley Colborne, M.D.

James Gooden.

Peter Grant.

John Alexander Henderson.

Thumas Hill.

George Loddiges. Earl of Powis.

$$
1832-33 .
$$

Thomas Andrew Knight, President.

Edward Barnard,

The Earl of Carnarvon, ${ }^{*} \quad$ Vice-Presidents.

Henry Moreton Dyer,

Alexander Henderson, M.D.,

Alexander Seton, Treasurer.

George Bentham, Secretary.

Richard Bligh.

Richard Chandler.

Major-General Thomas Bligh St. George

James Gooden.

Peter Grant. Thomas Hill.

Aylmer Bourke Lambert. George Loddiges. - Died during the jear.

$$
\text { 1833-34. }
$$

Thomas Andrew Knight, President.

Edward Barnard,

Henry Moreton Dyer Vice-Presidents.

Alexander Henderson, M. D.,

Alexander Seton, Treasurer.

George Bentham, Secretary.

Dr. Bostock.

Hasler Capron.

Richard Chandler.

Earl Fitzwilliam.

Major-General Thomas Bligh St. George.

James Gooden.

Peter Grant.

Joseph Kirke. Aylmer Bourke Lambert. 
OFFICE-BEARERS AND MEMBERS OF COUNCIL.

$$
1834-35 .
$$

Thomas Andrew Knight, President. $\left.\begin{array}{l}\text { Edward Barnard, } \\ \text { Henry Morton Dyer, } \\ \text { Alexander Henderson, M.D., }\end{array}\right\}$ Fice-Presiddents. Alexander Henderson, M.D. Alexander Seton, Treasurer. George Bentham, Sccrotcory. Charles Barclay.

Dr. Bostock.

Hasler Capon.

Richard Chandler.

Major-General Thomas Bligh St. George. Joseph Kirke.

Aylmer Burke Lambert.

George Loddiges, R. H. Sally.

$$
1835-36 .
$$

Thomas Andrew Knight, President. Edward Barnard,

$\left.\begin{array}{l}\text { Edward Barnard, } \\ \text { Henry Morton Dyer, } \\ \text { Alexander Henderson, M.D., }\end{array}\right\}$ Vice-Presidents. Thomas Edgar, Treasurer.

George Bentham, Secretary.

Charles Barclay.

Dr. Rostock.

Charles Brown.

Haslet Capon.

James Robert Gower.

Joseph Kike.

Aylmer Bourse Lambert.

George Loddiges. R. H. Sally.

$$
1836-37 .
$$

Thomas Andrew Knight, President.

$\left.\begin{array}{l}\text { Edward Barnard, } \\ \text { Henry Morton Dyer, } \\ \text { Alexander Henderson, M.D., }\end{array}\right\}$ Vice-Presidents.

Alexander Henderson, M. D.,

Thomas Edgar, Treasurer.

George Bentham, Secretary.

Dr. Bostock.

Haslet Capon, now Hollist.

James Robert Gown.

John Alexander Henderson.

Charles Holford.

Joseph Kirke.

George Loddiges.

R. H. Sally. Sir Henry Willock.

189
1837-38.

Thomas Andrew Knight, President.

$\left.\begin{array}{l}\text { Edward Barnard, } \\ \text { Henry Morton Dyer, } \\ \text { Alexander Henderson, M.D., }\end{array}\right\}$ Vice -Presidents.

Alexander Henderson, M.D.,

Thomas Edgar, Treasurer.

George Bentham, Secretary.

Duke of Devonshire.

James Robert Gower.

John Alexander Henderson.

Charles Holford.

Lancelot Holland.

George Lorldiges.

Hon. W. F. Strangways.

R. H. Solly. Sir Henry Willock.

$$
\text { 1838-39. }
$$

T. A, Knight,*

The Duke of Devonshire, Presidents.

Edward Barnard,

Henry Morton. Dyer,

Alexander Henderson, M.D.,

George Loddiges,

Thomas Edgar, Treasurer.

George Bentham, Secretary.

Henry Bevan.

Sir Philip de Malpas Grey Egerton, Bart.

John Alexander Henderson. Charles Holford.

Lancelot Holland. Sir Charles Lemon, Bart. Sir Oswald Moseley, Bart.

Hon. W. F. Strangways.

- Died May 11 th, 18s8, and replaced by the Duke of Detonslitre.

$$
\text { 1839-40. }
$$

Duke of Devonshire, President.

Edward Barnard,

Henry Morton Dyer,

Alexander Henderson, M.D.

George Loddiges,

Thomas Edgar, Treasurer.

George Bentham, Secretary.

Henry Bevan.

Sir Philip de Malpas Grey Egerton, Bart.

James Robert Goren.

Thomas Harris.

Sir Charles Lemon, Bart.

Sir Oswald Moseley, Bart.

E. W. Pendarves. R. H. Dolly.

D D 
APPENDIX.

$1810-41$.

Duke of Devonshire, Presidcrt.

Heury Moreton Dyer,

Alexander Hesuterson, M.D.,

Sir Charles Lemon, Bart.,

Tiee-Presilents.

George Iorddiges,

Thomas Edgar, Treasurer.

George Bentham, Secretary.

Sir Philip de Malpas Grey Egerton, Bart.

Edward Forster.

James Robert Gowen.

Thomas Harris.

E. W. Pondarves

John Rogers, Jun.

R. H, Solly, William Henry Fox Talbot.

$$
1841-42 .
$$

Duke of Devonshire, President.

Henry Moreton Dyer,"

R. H. Solly,

Sir Charles Lemon, Bart.,

George Loddiges,

Sir Oswald Moseley, Bart.,

Thomas Edgar, Treasurer.

Alexander Henderson, M.D., Secretary.

Edward Barnard.

George Bentham.

Earl of Dartmouth.

James Robert Gowen.

Edward Forster.

William Haseldine Peny .

E. W. Pendarves.

- Died during the year, and replaced an Vice-President by $R$. H. Solly, and as member of Council by tie Earl of Dartanouth.

$$
1842-43 .
$$

Duke of Devonshire, President.

Sir Charles Lemon, Bart.,

$\left.\begin{array}{l}\text { George Loddiges, } \\ \text { Sir Oswald Moseley, Bart., }\end{array}\right\}$ Vice-Presidents.

R. H. Solly,

Thomas Edgar, Treasurer.

Alexander Henderson, M. D., Secretary.

R. W. Barchard.

Edward Barnard.

Earl of Dartmouth.

James Robert Gowen.

Sir William J. Hooker.

Earl of Ilchester.

William Haseldine Pepys. John Rogers.

$$
\text { 1843-44. }
$$

Duke of Devonshire, President.

The Earl of Auckland,

Sir Philip de M. G. Egerton, Bart., Trice-

Sir Charles Lemon, Bart.,

Sir Oswald Moseley, Bart

Thomas Edgar, Treasurer.

Alexander Henderson, MI. D., Secretary.

R. W. Barchard.

Edward Barnard.

Earl of Dartmouth.

Rohert Hutton.

Earl of Ilchester.

George Loddiges.

William Haseldine Pepys. R. H. Solly.

$$
1844-45 .
$$

Duke of Devonshire, President.

Earl of Auckland,

Sir Philip de M. G. Egerton, Bart., Vice-

Sir Charles Lemon, Bart.,

Sir Oswald Moseley, Bart.,

Thomas Edgar, Treasurer.

Alexander Henderson, M.D., Secretary.

R. W. Barchard.

Robert Hutton.

George Loddiges.

Sir Willian Middleton.

William Haseldine Pepys.

Lord Prudhoe.

Sigismund Rucker, Jun. $\quad$ R. H. Solly.

$$
1845-46 .
$$

Duke of Devonshire, President.

Earl of Auckland,

R. W. Barchard,

Sir Philip de M. G. Egerton, Bart.,
Sir Charles Lemon, Bart.,

Thomas Edgar, Treasurer.

James Robert Gowen, Secretary.

Robert Hutton.

George Loddiges.

Sir Willinm Middleton.

William Haseldine Pepys.

Henry Pownall.

Iord Prudhoe.

Sigisnund Rucker, Jun. $\quad$ C. B. Warner. 


\section{OFFICE-BEARERS AND MEMBERS OF COUNCIL.}

$$
1816-47 .
$$

Duke of Devoushire, President.

Earl of Auckland,

R. W. Barchard,

Sir Philip de M. G. Egerton, Bart., \} Presidents.

Sir Charles Lemon, Bart.,

Thomas Edgar, Treasurer.

James Robert Gowen, Secretary.

Colonel Edward Baker.

Frederick George Cox.

Robert Hutton.

Sir William Middleton.

Henry Pownall. Sigismund Rucker, Jun. Sir George Staunton. C. B. Warner.

$$
1847-48 .
$$

Duke of Devonshire, President.

Earl of Auckland,

R. W. Barchard, "

Sir Philip de M. G. Egerton, Bart., ( Presidents.

Sir Charies Lemon, Bart.

Thomas Edgar, Treasurer.

James Robert Gowen, Secretary.

Colonel Edward Baker.

John Jackson Blandy.

F. G. Cox.† R. W. Eyles.

Robert Hutton. Duke of Northumberland.

W. W. Salmon. R. H. Solly.

Sir George Staunton. C. B. Warner.

- Died Feb. 1848, and replaced by W. W. Salmon. t Died June, 1847, and replaced by $\mathrm{g}$. $\mathrm{H}$. Solly.

$$
1848-49 \text {. }
$$

Duke of Deronshire, President.

Lord Ashburton,

Earl of Auckland, \pm

J. J. Blandy, Tice-Presidents.

Sir Charles Lemon, Bart.

Duke of Northumberland,

Robert Hutton, Treasurer.

James Robert Gowen, Secretary.

Dr. Daniel.

J. E. Denison.

Sir Philip de Malpas Grey Egerton, Bart. R. W. Eyles.
W. W. Salmon.
J. S. Schroder.

Sir George Staunton.

C. B. Warner.

* Died Jan. $[8 \nless 9$, and replaced by Lord Ashburton.

$$
1849-50 \text {. }
$$

Duke of Devonshire, President.

Lord Ashburton,

Sir Philip de M. G. Egerton, Bart., $\quad$ Vice-

Sir Charles Lemon, Bart.,

Duke of Northumberland,

Robert Hutton, Treasurer.

James Robert Gowen, Secretary.

John Jackson Blandy.

Colonel Challoner.

Dr. Daniel.

J. E. Denison.

R. W. Eyles.

Dr. Jackson.

W. W. Salmon, Bishop of Winchester.

$$
1850-51 .
$$

Duke of Devonshire, President.

Lord Ashburton,

J. E. Denison,

Duke of Northumberland, Presidents.

Bishop of Winchester,

James Robert Gowen, Treasurer.

Dr. Daniel, Secretary.

J. Barchard.

John Jackson Blandy.

Colonel Challoner.

R. S. Holford.

Rowert Hutton.

Dr. Jackson.

W. W. Salmon. James Morgan Strachan.

$$
1851-52 .
$$

Duke of Devonshire, President.

Lord Ashburton,

Sir Philip de M. G. Egerton, Bart., Tice-

Duke of Northumberland,

Bishop of Winchester,

James Robert Gowen, Treasurer.

Dr. Royle, Secretary.

John Barehard.

John Jackson Blandy.

Colonel Challoner.

Robert Hutton.

Dr. Jackson.

Sir Charles Lemon, Bart.

W. W. Salmon, James Morgan Strachan. 


\section{APPENDIX.}

$$
1852-53 .
$$

Duke of Devonshire, President. Lord Ashburtou,

Sir Philip de M. G. Egerton, Bart., Sir Charles Lomon, Bart., James Morgan Strachan,

James Robert Gowen, Treasurer.

Dr. Royle, Sccretary.

John Jackson Blandy.

Colonel Challoner.

R. S. Holford.

Robert Hutton.

Dr. Jackson.

Sir Peter Pole, Bart.

G. Rushout. W. W. Salmon.

$$
1853-54 .
$$

Duke of Devonshire, President Sir Philip de M. G. Egerton, Bart., Robert Hutton,

Duke of Northumberland, James Morgan Strachan,

James Robert Gowen, Treasurer.

Dr. Royle, Secrelary.

John Jackson Blandy.

Colonel Challoner.

James Gadesden.

R. S. Holford.

Dr. Jackson.

Sir Peter Pole, Bart.

George Rushout. Rt. Hon, Laurence Sulivan.

$$
\text { 1854-55. }
$$

Duke of Devonshire, President.

Sir Philip de M. G. Egerton, Bart., Robert Hutton,

Vice-

James Morgan Strachan, Presidents.

Right Hon. Laurence Sulivan,

James Robert Goweu, Treasurer.

Dr. Royle, Secretary.

John Jackson Blandy.

Colonel Challoner.

General Fox.

James Gadesden.

Rev. W. L. Hawkins.

Dr. Jackson.

George Rushout. J. C. Whiteman. Presidents.
$1855-56$.

Duke of Devonshire, President Sir Philip de M. G. Eigerton, Bart., Duke of Northumberland, ViceSir Sarnuel Morton Peto, Bart., (Presidents. Right Hon, Laurence Sulivan, * Dr. Jackson, Treasurer. +

Dr. Royle, Secretary.

John Jackson Blandy. Colonel Challoner James Gadesden. James Robert Gowen.* Rev. W. B. L. Hawkins. Robert Hutton. Sir Joseph Paxton. James Morgan Strachan. *

- Resigned Feb. 1856, and replaced by the Rev. Levison Vernon Harcourt, James Veitch, Jun., John Spencer. + Replaced on his death hy Mr. William Wilson Saunders, who

$$
1856-57 .
$$

Duke of Devonshire, President.

John Jackson Blendy,

Rev. Levison Vernon Harcourt,

Sir Joseph Paxton, M.P., ViceSir Samuel Morton Peto, Bart., W. Wilson Sauuders, Treasurer. Dr. Royle, Secretary.

H. G. Bohn.

Colonel Challoner.

Rev. W. B. L. Hawkins.

John Lee.

Conrad Lodidiges. Sigismund Rucker John Spencer, James Veitch, Juu.

$$
1857-58 .
$$

$\left.\begin{array}{l}\text { H.R.H. the Prince Consort, } \\ \text { Duke of Devonshire, } t\end{array}\right\}$ Presidents. John Jackson Blandy, Charles Wentworth Dilke, Rev. Levison Vernon Harcourt, Presidents, Bishop of Winchester,

W. Wilson Saunders, Treasurer. Dr. Royle, Secretary. \&

H. G. Bohn.

Colonel Challoner.

John Lee. Conrad Loddiges.

Sigismund Rucker. J. R. Scott.

John Spencer. James Veitch, Jun.

‡ Replseed on his death by H.R. I. the Prince Consort, who

was elected March snd, 1F58. 


\section{OFFICE-BEARERS AND MEMBERS OF COUNCIL.}

\section{$1858-59$.}

H.R.H. The Prince Consort, President.

John Jackson Blandy,

Charles Wentworth Dilke, Vice-

Rev. Levison Vernon Harcourt, Presidents

Sir John W. Ramsden, Bart.,

W. Wilson Saunders, Treasurer.

Dr. Lindley, Secretary.

H. G. Bohn.

Colonel Challoner.

Robert Glendinning.

S. H. Godson.

John Lee.

J. R. Scott.

John Spencer.

James Veitch, Jun.

$$
1859-60 .
$$

H.R.H. The Prince Consort, President. John Jackson Blandy, Charles Wentworth Dilke, Earl of Ducie, $\left\{\begin{array}{c}\text { Vice- } \\ \text { Presidents. }\end{array}\right.$

Rev, Levison Vernon Harcourt,

W. Wilson Saunders, Treasurer.

Dr. Lindley, Secretary.

H. G. Bohn.

Colonel Challoner.

Earl of Ducie.

Charles Fimonds.

Professor Henfrey.

John Lee.

J. R. Scott.

James Veitch, Jun.

MAY, 1860, to FEB. 1862.

H.R.H. The Prince Consort, President,* John Jackson Blandy,

Sir Wentworth Dilke, Bart, Earl of Ducie,

Rev. Levison Vernon Harcourt, $\left.{ }^{+}\right\}$Presidents. The Bishop of Winchester,

- Died Dec. 14th, 1861, and not replaced until next anniversary meeting, Feb. 11th, 186 ?

+ Replaced on his death by the Bishop of winchester, who Fins elected Sept. 4 th, 1860 .
MAT, 1860, to Fев. 1862 (continued).

W. Wilson Saunders, Trecasurer.

Dr. Lindley, Secretary.

John Clutton.

Charles Edrnonds.

S. H. Godson.

Henry T. Hope.

John Lee.

Hezry Pownall.

James Veitch, Jun.

Robert Wrench.

1862.

Duke of Buccleuch, Presidcrt.

John Jackson Blandy,

Sir Wentworth Dillke, Bart.,

Earl of Ducie, Vice-Presidents.

Bishop of Winchester,

W. Wilson Saunders, Treasurer

Dr. Lindley, Secretary.

John Clutton.

R. Cooper.

John Fleming.

S. H. Godson.

John Lee.

Henry Pownall.

Earl Somers.

James Veitch, Jun.

\section{3.}

Duke of Buccleuch, President.

John Jackson Blandy,

Sir Wentworth Dilke, Bart.,

Earl of Ducie,

Dr. Lindley,

John Clutton, Treasurer.

W. Wilson Saunders, Secretary.

Sir Daniel Cooper, Bart.

R. Cooper.

Rev. Joshua Dix.

John Fleming.

S. H. Godson.

John Kelk.

John Lee.

James Veitch. 


\section{APPENDIX.}

\section{IV.-ORIGINAL OHARTER OF THE HORTICULTURAL SOCIETY OF LONDON.}

GEorge THe ThIRD, by the Grace of God, of the United Kingdom of Great Britain and Ireland King, Defender of the Faith, to all to whom these presents shall come, Greeting : Whereas several of our loving Subjects are Object of desirons of forming a Society for the Improvement of Horticulture in all its
the Society. branches, ornamental as well as useful, and having subscribed considerable sums of money for that purpose, have humbly besought us to grant unto them and such other persons as shall be approved and elected as hereinafter is mentioned, Our Royal Charter of Incorporation for the purposes aforesaid:

Know $\mathrm{Ye}$, that $\mathrm{We}$, being desirous to promote such improvement, have, of our especial grace, certain knowledge, and mere motion, Given and Granted, and we do hereby Give and Grant, that Our Right Trusty and Wellbeloved Cousin and Counsellor George Earl of Dartmouth, Knight of the Most Noble Order of the Garter, Our Right Trusty and Wellbeloved Cousin and Counsellor Edward Earl Powis, our Right Reverend and Wellbeloved Father in God Brownlow Lord Bishop of Winchester, Our Right Trusty and Wellbeloved John Lord Selsey, Our Right Trusty and Wellbeloved Counsellor Charles Greville, Our Right Trusty and Wellbeloved Counsellor Sir Joseph Banks, Baronet and Knight of the Most Honourable Order of the Bath, Our Trusty and Wellbeloved William Townsend Aiton, John Elliot, Thomas Andrew Knight, Charles Miller, Richard Anthony Salisbury, and John Trevelyan, Esquires, and James Dickson, Thomas Hoy, and William Smith, Gardeners, and such others as shall from time to time be appointed and elected in the manner hereinafter directed, and their Successors, be and shall for ever hereafter continue to be, by virtue of these Presents, one Body Corponte
Name. Politic and Corporate, by the name of "THe HorTicultural SOCIETY or LoNDON;" and them and their Successors, for the purposes aforesaid, We do hereby constitute and declare to be one Body Politic and Corporate, and by the same name to have perpetual Succession, and for ever hereafter to

Pusver to purvintse Lands. be Persons able and capable in the Law, and have power to purchase, receive, and possess any Coods and Chattels whatsoever, and (notwithstanding the Statutes of Mortmain), to purchase, hold, and enjoy, to them and their Successors, any Lands, Tenements, and Hereditaments whatsoever, not exceeding, at the time or times of purchasing such Lands, Tenements, and Hereditaments respectively, the yearly value at a Rack Rent of One Thousand Pounds in the whole, without incurring the penalties or forfeitures of the Statutes of Mortmain, or any of them : and by the name aforesaid to sue and 
THE ORIGINAL CHARTER.

be sted, plea and be impleaded, answer and be answered unto, defend and be defended in all Courts and places whatsoever, of Us, our Heirs, and Successors, in all Actions, Suits, Causes, and Things whatsoever ; and to act and do in all Things relating to the said Corporation in as ample manner and form as any other Liege Subjects, being Persons able and capable in the Law, or any other Body Politic or Corporate, in our said United Kingdom of Great Britain and Ireland, may or can act or do : and also to have and to To use a use a Common. Seal, and the same to change and alter from time to time as Seal. they shall think fit.

And We do hereby declare and grant that there shall be an indefinite Number of number of Fellows of the said Society; and that they the said George Earl Fellows in of Dartmouth, Edward Earl Powis, Brownlow Lord Bishop of Winchester, First FelJohn Lord Selsey, Charles Greville, Sir Joseph Banks, William Townsend Aiton, John Elliot, Thomas Andrew Knight, Charles Miller, Richard Anthony Salisbury, John Trevelyan, James Dickson, Thomas Hoy, and William Smith, shall be the first Fellows of the said Society, and that any five or more of them, all having been first duly summoned to attend the Meetings of the said Fellows, shall and may, on or before the First day of May next ensuing the date of these presents, under their respective hands, in writing, appoint such other persons to be Fellows, Honorary Members, and Foreign Members of the said Society, as they may respectively think fit.

And We do further declare and grant, that, for the better Rule and conncilami Government of the said Society, and for the better direction, management, and execution of the Business and Concerns thereof, there shall be thenceforth for ever a Council, President, Treasurer, and Secretary of the said Society, to be elected in manner hereinafter mentioned; and that such Council shall consist of fifteen Members to be elected from among the Fellows as hereinafter directed, whereof any five shall be a quorum; and We do hereby Firstcounnominate and appoint the said George Earl of Dartmouth, Edward Earl cil and onti. Powis, Brownlow Lord Bishop of Winchester, John Lord Selsey, Charles Greville, Sir Joseph Banks, William Townsend Aiton, John Elliot, Thomas Andrew Knight, Charles Miller, Richard Anthony Salisbury, John Trevelyan, James Dickson, Thomas Hoy, and William Smith, to be the first Council; the said George Earl of Dartmouth to be the first President; the said Charles Greville to be the first Treasurer; and the said Richard Anthony Salisbury to be the first Secretary to the said Society: all and each of the aforesaid Officers and Counsellors to continue in such their respective Offices until the First day of May One Thousand Eight Hundred and Ten : and that the said George Earl of Dartmouth shall bave power to appoint such four Persons from and amongst the Members of the said Council, to be Vice-Presidents of the said Society, as he shall think fit, until some other Persons shall be chosen in their respective rooms, in the manner hereinafter mentioned.

And it is Our further Will and Pleasure that the Fellows of the said Annual ReSociety, or any eleven or more of them, shall and may, on the First day of three Mem1 1.5 


\section{APPENDIX.}

bers of Colection of alection of thethers

$$
\text { las }
$$
manner by method of Ballot elect three other discreet Persons from amongst the Fellows of the said Society to supply the places and offices of such three as may have been so put out and removed; it being our Royal Will and Pleasure that one-fifth of the said Council and no more shall be annually

Annual Annual
Offiction of
Ofice changed and removed by the Fellows of the said Society : And also that they the said Fellows, or any eleven or more of them, shall and may at the time and in manner aforesaid, by method of Ballot, elect from amongst the Members of the said Council, when formed and elected in manner aforesaid, three fit and proper Persons ; one of such Persons to be President, another of such Persons to be Treasurer, and the other of such Persons to be Secretary Vacancios occasioned the said Society for the year ensuing : And also, in like manner, shall and may, in case of the death of any of the Members of the Council, or of the President, Treasurer, or Secretary for the time being, within the space of two months next after such death or deaths, in like manner elect other discreet Persons, being Fellows of the said Society, to supply the places and Offices of such Members of the said Council, or of the President, Treasurer, or Secretary so dying: And also shall and may appoint such other Persons to be Officers of the said Society for the year ensuing as they may think proper and necessary for the transacting and managing the Business thereof.

And it is Our further Will and Pleasure that, so soon after the Elections aforesaid as conveniently may be, the Person who shall at any time hereafter be elected to be President of the said Society, in manner aforesaid, may and shall nominate and appoint four Persons, being Members of the said Council, to be Vice-Presidents of the said Society for the year ensuing.

Flection and And We do further declare and grant, that, from and after the first day of Remuval of
Members. May now next ensuing, the Fellows of the said Society, or any seven or more of them, shall and may have power from time to time at the general Meetings of the said Society, to be held at the usual place of meeting of the said Society or at such other place as shall have been in that behalf appointed, by method of Ballot, to elect such Persons to be Fellows, Honorary Members, and Foreign Members of the said Society, and all Fellows, Honorary Members, and Foreign Members, to remove from the said Society as they shall think fit. Provided that no such Fellow, Honorary Member, and Foreign Member shall be declared elected or removed, unless it shall appear upon such Ballot that twothirds of the Fellows present at such Meeting shall have voted for the same.

And We do further declare and gxant that the Council hereby appointed, and the Council of the said Society for the time being, or any three or more of them (all the Members thereof having been first duly summoned to attend
The Councis to make $\mathrm{BY}$ Laws. 
THE ORIGINAL CHARTER.

the Meetings thereof), shall and may have power according to the best of their judgment and discretion to make and establish such By-Laws as they shall deem useful and necessary for the Regulation of said Society, and of the Estate, Goods, and Business thereof, and for fixing and determining the times and places of meeting of the said Society, and also the times, place, and manner of electing, appointing, and removing all Fellows, Honorary Members, and Foreign Members of the said Society, and all such Subordinate Officers, Attendants, and Servants as shall be deemed necessary or useful for the said Society; and also for filling up from time to time any vacancies which may happen by death, removal, or otherwise, in any of the Offices or Appointments constituted or established for the execution of the Business and Concerns of the said Society; and also for regulating and ascertaining the qualifications of Persons to become Fellows, Honorary Members, and Foreign Members of the said Society, respectively; and also the Sum and Sums of Money to be paid by them respectively, whether upon admission or otherwise, towards carrying on the purposes of the said Society ; and such By-Laws, from time to time, to vary, alter, or revoke, and make such new and other By-Laws as they shall think most useful and expedient, so that the same be not repugnant to these Presents or the Laws of this our Realm.

Provided that no By-Law hereafter to be made, or alteration or repeal of By-Laws to any By-Law which shall hereafter have been established, by the said Council by Ballot at hereby appointed, or by the Council for the time being of the said Society, Meeting. shall be considered to have passed and be binding on the said Society, until such By-Law or such alteration or repeal of any By-Law shall have been hung up in the Common Meeting-Room of the said Society, and been read by the President, or any one of the Vice-Presidents for the time being, at two successive General Meetings of the said Society, and until the same shall have been confirmed by Ballot by the Fellows at large of the said Society ; such Ballot to take place at the ensuing Meeting next after such two Successive General Meetings of the said Society, seven at least of the Fellows of the said. Society being then present : and Provided that no such By-Law, or alteration or repeal of any By-Law, shall be deemed or taken to pass in the affirmative, unless it shall appear upon such Ballot that two-thirds of the Fellows present at such Meeting shall have voted for the same.

Witness His Majesty at Westminster, the 17th day of April, in the Fortyninth year of Our Reign.

By Writ of Privy Seal,

WILMOT.

$19 \%$

E E 


\section{APPENDIX}

\section{V.-NEW CHARTER AND AGREEMENTS OF THE ROYAL IIORTICULTURAL SOCTETY.}

VICTORIA, by the Grace of God, of the United Kingdom of Great Britain and Ireland Queen, Defender of the Fuith, to all to whom these presents shall come, Greeting :

First Ineot: the Society by Letters Patent, 48

First igrcement Culninis. sioners of this Exlibition of 1sin and

1. WHEREAS the Horticultural Socrety of London, hereinafter referred to as "the said Society," was incorporated by Royal Letters Patent under the Great Seal of our said United Kingdom, bearing date at Westminster the 17th day of April in the 49th year of the reign of His late Majesty King George the Third, for the purpose of the improvement of Horticulture in all its branches, ornamental as well as useful.

2. And whereas it has been represented to Us, that the said Society has sedulously pursued and successfully promoted the objects for which it was incorporated: And it has been also represented to Us that, with the view of still further promoting such objects, an arrangement was lately entered into between the Commissioners for the Exhibition of 1851 (hereinafter referred to as "the Commissioners") and the said Society, which is contained in certain Articles of Agreement, dated the 24th day of July, 1860, and sealed with the corporate seals of the Commissioners and the said Society respectively, whereby it was agreed (amongst other things) : first, that a piece of land at Kensington Gore, containing 20 acres, or thereabouts, part of the estate of the Commissioners, should be leased to the said Society for a term of years; secondly, that the said Society, immediately after the execution by the said Commissioners of certain earthworks, should lay out and construct on the land an ornamental garden, with walks, trees, shrubs, terraces, steps, fountains, band-houses, statues, and rases, and at the north end of the said land a conservatory or winter garden, and expend not less than $£ 50,000$; and, thirdly, that the Commissioners, simaltaneously with the progress of the works of the said Society, should at their own cost enclose the said land with arcades, distinguished as the upper arcades, central areades, and lower arcades respectively, and that the upper arcades (except the parts thereof coloured green in the plan annexed to the said Articles of Agreement), and certain rights and easements as to the use or enjoyment of the central and lower arcades and the excepted parts of the upper arcades, should be included in the lease of the said land, and that the Commissioners shall expend the sum of $£ 50,000$ about such earthworks, and in erecting the said arcades. And it is also represented to Us, that under the said Articles of Agreement the sum of $£ 40,000$ (part of the $£ 50,000$ to be expended by the said Society) is to be raised by debentures 


\section{NEW CHARTER AND AGREEMENTS.}

(the remainder of the $£ 50,000$ having been already raised by donations and First Agrec fees on the admission of Life Members), and divers stipulations or agreements comminsare made thereby or contained therein for the application and disposition of 4 (unu $d$ i the income of the said Society, it being part of such arrangements that the "receipts from the gardens," consisting of and including the moneys and income therein mentioned in that behalf, should be applied or disposed of in the following manner, viz., out of the gross amount of the "receipts from the gardens," such a sum as shall from time to time be allowed by the Committee hereinafter mentioned, in respect of the expenses therein mentioned of the said Society, and of carrying on the operations and concerns thereof, is in the first place to be retained by the said Society ; secondly, there is to be then retained by the said Society, out of such receipts, the amount which may be, from time to time, payable by the said Society in respect of interest, not exceeding $£ 5$ per cent. on the sum of $£ 40,000$, to be borrowed on debentures as aforesaid, or on so much of the said sum of $\mathfrak{E} 40,000$ as may remain unpaid or undischarged; and, thirdly, there is then to be paid by the said Society to the Commissioners, as rent, the yearly sum of $£ 2145$, if the receipts shall be adequate for such payment, after retaining to the said Society the sums authorised to be retained by them, as therein mentioned, for the expenses and for the interest respectively aforesaid; but otherwise, such a sum only as shall be equal from year to year to the residue of the receipts over and above the sums so in precedence; and if there shall remain any surplus over and above the several payments hereinbefore mentioned, out of the "receipts from the gardens," there is to be paid to the Commissioners for their own use and as additional yearly rent, a sum equal to half such surplus ; and, further, that by the said Articles of Agreement, it is provided or stipulated that for the purpose of regulating the amount to be retained by the said Society in each year for expenses, a Committee shall be appointed annually, which Committee is to consist of six persons, three of whom are to be appointed by the Commissioners and three by the said Society, and any three of such Committee are to form a quorum, so as one, at least, shall be a person appointed by the Commissioners, and one shall be a person appointed by the said Society; and as vacancies occur in each year, by death, incapacity, or resignation, such vacancies are to be filled up respectively by the Commissioners or the said Society, according as the original appointments were made by them respectively; and further, that the Committee is from time to time to select one of those Committee-men who have been appointed by the Commissioners as Chairman of such Committee, and he is to have an equal rote with the other Committee-men for the time being acting, and in case of equality a casting vote in addition; and the Committee is to have power to make bye-laws for their own government in the execntion of the duties confided to them; and that it is also thereby provided or stipulated that the said Society shall devote and apply towards the liquidation of the debt of $£ 40,000$, to be raised by debentures as aforesaid, three-fifths of the money actually received by them 


\section{APPENDIX.}

from time to time, in respect of the "receipts from the gardens," after the retentions and payments aforesaid from and out of the "receipts from the gardens," for expenses and interest by the said Society and the rent to the Commissioners, and divers other agreements or stipulations for carrying into effect, or consequent on, or relating to the said arrangement are contained in the said Articles of Agreement.

3. And whereas it is further represented to Us, that by a Supplemental

Necond Agreement
with Commissioners.

Agreement, dated the 20th day of November in the year 1860, and made and entered into in like manner between the said Commissioners of the one part, and the said Society of the other part (in which the said piece of land is referred to as "the gardens"), an arrangement has been made between the said parties for the occupation by the said Society of some additional land of the Commissioners shown on the plan annexed to such supplemental Agree. ment by a red colour adjoining or near "the gardens" (which additional land the Commissioners had, for the reason therein mentioned declined to include in the lease to be granted under the first-mentioned Agreement), and for an access to "the gardens" by means of a lane or path shown on the same plan, marked with the colour "brown," and by the said supplemental Agreement the interest of the said Society in or with respect to the said additional land, and the right of the said Society with respect to such access, with the duties and rights of the said Society concerning the said additional land and access respectively are defined (the rent payable by the said Society in respect thereof being the nominal rent of 1s.), and power is reserved to the Commissioners at any time to resume possession of such additional land, and also, upon providing another road as therein mentioned, to stop up or take away the said road by or over which there is such access as aforesaid afforded to "the gardens."

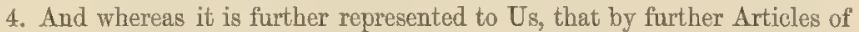
Third Agree-
ment with ment with
Lummissioners. Agreement, dated the 1st day of March, in the year 1861, made and entered into in like manner between the said Commissioners of the one part, and the said Society of the other part ; after reciting the aforesaid Articles of Agreement of the 24th day of July, 1860, and setting forth divers of the clauses or provisions contained in the same Articles, and reciting that the said Bociety and the Commissioners are each desirous of respectively having the right of increasing the outlay by them respectively undertaken to be made by the said therein-recited Agreement, to any amount not exceeding as to each of them the sum of $£ 10,000$ over and above the respective sums of $£ 50,000$ by them respectively undertaken to be laid out as aforesaid, and of acquiring such rights and privileges as in the said further Agreement now in recital appear in respect of such additional outlay if made, it is thereby mutually agreed between the Commissioners and the said Society (amongst other things) that the said Society may at any time before the 1st day of January, 1864 , borrow, or take up on their debentures or other securities, any sum or sums of money not exceeding in the whole the sum of $£ 10,000$ in addition to the sum of $\$ 40,000$ in the said therein-recited Agreement mentioned as 
NEW CHARTER AND AGREEMENTS.

having been borrowed, or for the borrowing of which arrangements had been Third Agree made, and may within the like period lay out and expend the sum or sums so commisborrowed in addition to the original sum of $£ 50,000$ therein mentioned of the sioners (consaid Society, in and about such works and things as are in the clause in the said Agreement now in recital referred to as the 1st clause of the said thereinrecited Agreement (being the clause secondly mentioned in the recital hereinbefore contained of such Agreement) undertaken to be done by them, and in and abont which such original sum of $£ 50,000$ is required by that clause to be expended, and that the Commissioners may at any time before the 1st day of January, 1864, lay out and expend such sum or sums of money as they may think fit, not exceeding in the whole the sume of $£ 10,000$, in addition to the original sum of $£ 50,000$ in the clause in the said Agreement now in recital referred to as clause 2 of the said therein-recited Agreement (being the clause thirdly mentioned in the recital hereinbefore contained of such Agreement) mentioned in and about such works, matters, and things as by that clause are undertaken to be done by them, and in and about which the same sum of $£ 50,000$ is required by that clause to be expended by them, and further that in case both or either of the parties thereto should think fit to make any such outlay, such parties respectively or party shall have no claim or demand against the other of them or against the gardens, or against the receipts from the gardens, save and except as thereinafter mentioned; videlicet, that with a view to compensate such parties respectively, or party, in some degree for such additional outlay, the following alterations should be made in the said therein-recited Agreement and in the lease to be granted pursuant thereto, videlicet, the 14th clanse (which provides for the application and disposition of the "receipts from the gardens," as hereinbefore mentioned) shall be altered and amended as follows, viz:-Out of the gross amount of the receipts from the gardens there shall be first retained by the said Society such a sum as shall from time to time be allowed by the Expenses Committee, mentioned in the therein and first herein-recited Agreement in respect of the expenses mentioned in the said Agreement now in recital, being the same expenses as in the said therein and first herein-recited Agreement are directed to be first retained by the said Society from and out of the "receipts from the gardens." 2ndly. There shall be then retained by the said Society out of such receipts the amount which may be from time to time payable by the said Society in respect of interest not exceeding $£ 5$ per cent. per annum, on the sum of $£ 40,000$ originally borrowed or agreed to be borrowed by them on debentures as aforesaid and on any further sum or sums they may borrow and expend in accordance with clause 1 of the Agreement now in recital, not exceeding $£ 10,000$, or on so much of the original and additional sums as for the time being may have been raised and shall not have been paid off; and, 3rdly, there shall then be paid by the said Society to the said Commissioners, as rent, the yearly sum or sums therein and hereinafter in that behalf mentioned, if the receipts shall be adequate for such payment, after retaining to the said 201 


\section{APPENDTX.}

Third Apreoment with

Commis

tinued). recital they shall expend a larger sum, then an addition shall be made to such rent at the rate of $£ 45$ s. for every additional $£ 100$ which the Commissioners shall think fit to expend in accordance with that clause, not exceeding $£ 10,000$ in the whole. And if there shall remain any surplus over and above the said several payments thereinbefore directed to be made or retained out of the "receipts from the gardens," there shall be paid to the Commissioners for their own use, and as additional rent, yearly (whether or not they make any additional outlay), a sum equal to half such surplus, and that it is by the said Agreement now in recital also provided (inter alia) that the clause (therein referred to as the 17 th clanse) of the said therein and first herein-recited Agreement relating to the application of the three-fifth shares of the said Society towards the liquidation of the said debenture debt of $£ 40,000$ shall be altered as follows : videlicit, the said Society shall devote and apply towards the liquidation of their debenture debt (whether it amount to the original sum of $£ 40,000$ only, or any increased amount under the authority of clause 1 of the Agreement now in recital,) three-fifths of the money actually received by them from time to time in respect of the "receipts from the gardens," after the payments directed to be retained out of the said receipts for expenses and interest by the said Society and the rent to the Commissioners, and that certain alterations consequential on the execution of the said Agreement now in recital are thereby made in the other agreements or stipulations contained in the said therein and first herein-recited Agreement and hereinbefore mentioned or referred to.

The neces- 5. And whereas it is further represented to Us that, in consequence of the

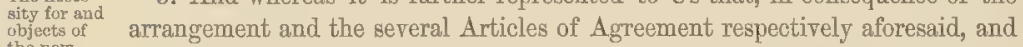
the new in order that the same and the objects thereof may, so far as regards the said Society, be fully carried into effect, it is necessary or expedient that the constitution of the said Saciety should be in some respects altered, and that the powers of the said Society should be enlarged, and it is also represented to Us that the usefulness of the said Society would be increased thereby, and that the said Society has consented thereto. Therefore We have been besought to grant unto the persons now composing the Horticultural Society of London, and such other persons as shall be approved of and elected as hereinafter mentioned, Our Royal Charter of incorporation for the purposes aforesaid, and with and under such powers and directions as hereinafter mentioned. And it is Our will and pleasure that such Society shall henceforth be called "The Royal Horticulturat Society."

Incorpora-
tion of the 
NEW CHARTER AND AGREEMENTS.

said Society, and of increasing the usefulness thereof, have, of Our especial grace, certain knowledge, and mere motion, given and granted, and We do hereby give and grant, That Our right, trusty, and well-beloved Cousin Henry John, Earl Duce, Fellow of the Royal Society; Charles Richard, I ord Bishop of Winchester, Prelate of the Most Noble Order of the Garter; John Jackson Bandy, John Glutton, Charles Wentworth Dike the younger, Charles Edmonds, Septimus Holmes Godson, Henry Thomas Hope, John Lee, Henry Pownall, James Veitch the younger, and Robert Wrench, (being respectively some of the persons now composing the Horticultural Society of London,) and all other persons now (with the persons respectively hereinbefore named) being Fellows or Members of the said Society, and such others as from time to time shall be appointed and elected in the manner hereinafter directed, and their successors, be and shall for ever hereafter continue and be, by virtue of these presents, one body politic and corporate, by the name of "The Royal Horticultural Society;" and them and their successors, for the corporate purposes for which the Horticultural Society of London was incorporated by the same Letters Patent, and with and subject to such additions and modifications to or in the same purposes as appear in and by or flow from, or are consequent on, the said arrangement between the said Commissioners and the said Society, and the said Articles of Agreement of the 24th day of July, 1860, and of the 20th day of November, 1860, and of the Mst day of March, 1861, respectively, We do hereby constitute and declare to be one body politic and corporate, and by the same name to have perpetual succession, and for ever hereafter to be persons able and capable in the law, and to have power to hold and to purchase, receive and possess the goods and chattels already rested in or belonging to the Horticultural Society, incorporated by the recited Letters Patent, and any other goods and' chattels whatsoever, and (notwithstanding the Statutes of Mortmain) to hold and to purchase, hold and enjoy to them and their successors, any lands, tenements, and hereditamints whatsoever, including as well the lands, tenements, and hereditaments now vested in or belonging to the said Society, or agreed to be leased to them as hereinbefore recited, as all other lands, tenements, and hereditaments wheresoever situate, such other lands, tenements, and hereditaments not exceeding in the whole the annual value of $£ 5000$, without incurring the penalties or forfeitures of the Statutes of Mortmain or any of them, and by the name aforesaid to sue and be sued, plead and be impleaded, answer and be To sue and answered unto, defend and be defended, in all courts and places whatsoever of Us, Our heirs and successors, in all actions, suits, causes, and things whatsoever, and to act and do in all things relating to the said corporation in as ample manner and form as any other Our liege subjects being persons able and capable in the law, or any other body politic or corporate in our said United Kingdom of Great Britain and Ireland, may or can act and do, and Torse also to have and to use a common seal, and the same to change and alter from seal. time to time as they shall think fit.

203
Power to hold good ing to the ti s linteliane other grids and lands. be sunned. sent and apinter onfirmitof the listing now belong 


\section{APPENDHX.}

Fellows.

7. And We do hereby declare and grant that the several persons who respectively now are as aforesaid Members or Fellows of the first-mentioned Society, shall be or continue Members or Fellows, and shall be and continue subject and liable to all such duties and obligations as they are now subject or liable to as Members or Fellows of the first-mentioned Society, and that all such persons as shall be appointed and elected as hereinafter mentioned shall likewise become or be Fellows or Members of "the Society" hereby incorporated, which is hereinafter referred to as "the Society."

Council and 8. And We do further declare and grant, that for the better rule and Council and
officers. government of "the Society," and for the better direction, management, and execution of the business and concerns thereof, there shall be henceforth such bodies and officers as are respectively hereinafter mentioned; that is to say, there shall be for ever a Council, one President, a Treasurer, and a Secretary of "the Society," appointed, and to be elected in manner hereinafter mentioned, and with reference to the said Articles of Agreement, dated the 24th day of July, 1860, between the said Commissioners and the "said Society," and so long as "the Society" shall hold and use or enjoy as aforesaid the said lands mentioned in the same Articles of Agreement of the Commissioners at Kensington Gore in pursuance of the said arrangement,

President. Treasurer.

Secretary.

Vice-PresiVice-Pre
dents. there shall be a Committee for regulating the amount to be retained by "the Society" in each year from the "receipts from the gardens" for expenses. The said Council shall consist of fifteen members appointed and to be elected as hereinafter mentioned, whereof any five shall be a quorum. The said Committee shall be appointed as hereinafter mentioned. And We do hereby nominate and appoint or confirm Our well-beloved Consort His Royal Highness Prince Albert, K.G., the said Earl Ducie, the said Bishop of Winchester, the said John Jackson Blandy, the said John Clutton, the said Charles Wentworth Dilke the younger, the said Charles Edmonds, the said Septimus Holmes Godson, the said Henry Thomas Hope, the said John Lee, John Lindley, F.R.S., the said Henry Pownall, William Wilson Saunders, F.R.S., the said James Veitch the younger, and the said Robert Wrench (who constitute the present Council of "the Society") the Council. And we do hereby further nominate and appoint or confirm His Royal Highness the Prince Consort (now being President) the President, the said William Wilson Saunders (now being the Treasurer) the Treasurer, and the said John Lindley (now being the Secretary) the Secretary, of "the Society," (all and each of the aforesaid Councillors and Officers to continue in such their respective offices until the second Tuesday in the month of February, 1862 ; and as regards such of the said Councillors as shall not be balloted out from time to time as hereinafter mentioned, they shall continue in office until so balloted out). And We do also hereby nominate and appoint and confirm the said Earl

Ducie, Bishop of Winchester, John Jackson Blandy, and Charles Wentworth Dilke (being the present four Vice-Presidents) to be the Vice-Presidents of 
NET CHARTER AND AGREEMENTS.

"the Society," until some other persons shall be chosen in their respective rooms in the manner hereinafter mentioned.

9. And with respect to the said Committee to be appointed for regulating the amount to be retained by "the Society" for the expenses aforesaid from the "receipts from the gardens," We do hereby further declare and grant that such Committee shall consist of six persons, three of whom shall be appointed by the Commissioners, and three by the Council of "the Society," as hereinafter mentioned, and any three of such Committee shall form a quorum, so as one at least shall be a person appointed by the Commissioners and one appointed by "the Society." As vacancies occur in each year by death, incapacity, or resignation, such vacancies may be filled respectively by the Commissioners and "the Society" respectively, according as the original appointments were made by them respectively. The Committee shall from time to time select one of those Committee-men who have been appointed by the Commissioners as Chairman of such Committee, which Chairman shall have the power of voting on all occasions equally with the other Committeemen for the time being acting; and such Chairman, in case of equality, shall have a casting vote in addition, and the said Committee shall have power to make bye-laws for their own government in the execution of the duties confided to them.

10. And it is our will and pleasure also, that the Fellows of "the Society," or any 11 or more of them, shall and may, on the second Tuesday in the month of February in the year 1862, and on the second Tuesday in the month of February in every succeeding year, assemble together at the then last or other usual place of meeting of "the Society," or some other convenient place (which meeting shall be called the "Annual Meeting,") and that at each and every such meeting the Fellows then present shall proceed by method of ballot to put out and remove some three of the Members of the Council of the preceding year, and shall and may, by method of ballot, elect three other discreet persons from amongst the Fellows of "the Society," to supply the places of such three as shall have been so put out and removed (so that onefifth of the Council shall be yearly removed and renewed by ballot as aforesaid). And it is Our will and pleasure also, that at each and every annual meeting the Fellows then present shall and may, in manner aforesaid, elect from among the Members of the Council for the year next ensuing, the President, Treasurer, and Secretary of "the Society" for such ensuing year (each of such offices to be filled by a distinct person), and also elect, as well in the first instance as annually from time to time afterwards from the members of "the Society," three persons, to form (with the three Committeemen appointed or to be appointed by the Commissioners, the Expenses Committee aforesaid for the year ensuing; and in case of the death or incapacity from any cause whatever of any of the Members of the Council, or of the President, Treasurer or Secretary for the time being, or of any of "the Society"s" Committeemen aforesaid, either before the first of the annual meetings ขบ

FF 


\section{APPENDIX.}

Annual rembers of Council and appoint. ment of ther officers (con-

\section{(t)}

aforesaid or between any two of such annual meetings, the said Council shall and may nominate or appoint some other discreet person or persons, being a Fellow or Fellows of "the Society," to supply the place or places of the Member or Members of Council and of the President, Treasurer, and Secretary respectively, and of the Committee-man or Committee-men respectively, or any or either of them respectively, so dying or becoming incapable, until the annual meeting next following such nomination or appointment ; and such Member or Members of Council, President, Treasurer, and Secretary, and Committee-men or Comnaittee-man respectively so nominated or appointed as aforesaid, shall until and on such next annual meeting be deemed to stand respectively for all purposes in the place of the person or persons respectively, or officers respectively, in or to whose place they respectively shall have been so nominated or appointed or should have succeeded; and further, as regards any Member or Members of Council dying or becoming incapable before the first annual meeting aforesaid, or in the interval between any two such annual meetings as aforesaid, and whose place or places shall not be supplied by the said Council as aforesaid, the place or places of such Member or Members of Council shall at the first or next annual meeting after the vacancy be supplied from the Fellows of "the Society," by ballot as aforesaid, and in such case the number of Fellows to be balloted out at such meeting shall be proportionably reduced, it being Our will and pleasure that the vacancy or vacancies by reason of death or incapacity, not supplied by the Council, and actually existing at the time of any annual meeting, shall be Resignation treated and supplied as and in lieu of a vacancy by ballot. And it is also our of Members of Council. will and pleasure that any such annual meeting as aforesaid may accept the resignation of, or for incapacity remove, any one or more of the Members of the Council for the time being, and elect in manner aforesaid any person or persons from among the Fellows in the place or places of the Members so retiring or being removed, in addition to the Member or Members which the Fellows present at such meeting are hereinbefore authorised to elect. And

Secretary may be a paid officer.

Expenses further, that it shall be lawful for any such annual meeting to resolve that the Secretary of "the Society" shall be a paid officer, and, accordingly, that such salary or compensation shall be paid to him as shall be determined by the said meeting, but in such case the Secretary shall be incapable of being a Member of the Council, and such meeting shall in manner aforesaid therempon appoint a Member of Council in his place. And it shall also be lawful for any such annual Meeting to resolve that the three Members appointed by the Society to form part of the Committee for regulating the amounts to be retained by the said Society for the expenses aforesaid shall be paid, and accordingly that such salary or compensation shall be paid to them as shall be determined by the said meeting, but in such case the said Members of such Committee shall be incapable of being Members of the Counci, and such meeting shall in manner aforesaid thereupon appoint Members of Council in their place.

11. And it is Our further will and pleasure, that so soon after the elections 
NEW CHARTER AND AGREEMENTS.

aforesaid as conveniently may be, the person who shall at any time hereafter be elected to be President of the said Society in manner aforesaid may and shall nominate and appoint four persons, being Members of the said Council, to be Vice-Presidents of "the Society" for the year ensuing.

12. And it is Our further will and pleasure that the three persons who shall be appointed by the Commissioners Members of the said Expenses Committee shall be appointed simultaneously with or immediately before or after the appointment of the Members of the said Committee who shall be appointed by the Council, and that notice thereof shall be given by the Commissioners to "the Society" at the time of or immediately after the said appointment by "the Society," and that such Committee shall continue for the year ensuing. Nevertheless, on the death or incapacity of any or either of the Committee-men appointed by the Commissioners before the expiration of their or his year of office, the place of such deceased or incapable Committeemen respectively, or Committee-man, may be forthwith supplied by the Commissioners, and the person or persons so appointed shall continue in office until the time at which the deceased or incapable Committeeman would have vacated his office, if living.

13. And We do further declare and grant, that on, or at any time and from time to time after, the said second Tuesday in February, 1862, the Fellows of "the Society," or any seven or more of them, shall and may have power at the general meetings of "the Society," to be held at the usual place of meeting of the Society, or at such other place as shall have been in that behalf appointed by open voting (unless five or more Fellows then present shall in writing require a ballot, and in such case by method of ballot,) to elect such persons to be Fellows, Honorary Members, and Foreign Members of "the Society" as they shall think fit, and any of the Fellows, Honorary Members, and Foreign Members for the time being to remove from "the Society," the majority of the Fellows voting, in case of open. voting, to bind the minority; in case of equality the Chairman to have a second or casting vote, but in case of a ballot no Fellow, Honorary Member, or Foreign Member shall be declared elected or removed, unless by a majority of twothirds of the Fellows voting at such ballot. In case of a ballot scrutineers to be appointed, and the ballot to be taken at an adjourned meeting, in the like manner as is hereinafter mentioned in the 16 th and 17th clauses; and further. that all such persons as shall be elected Fellows or Members of "the Society" (other than Honorary and Foreign Members) shall, at the time of their election, or before they shall be entitled to enjoy the rights or privileges of members, sign a note or memorandum in writing, binding them to observe, perform, and abide by all the rules, laws, and regulations of "the Society," and that such note or memorandum shall constitute an agreement to the effect thereof with "the Society," and shall or may be enforced by "the Society ;" and provided also that if any Member should refuse or neglect to pay his first Renewal , or any annual subscription for the space of six calendar months next after the

$20 \pi$

F $F$ ? 
APPEYDIX.

Remural of (contruner)

\section{The arrange} lwont lis: fween the
Connuis simners ind
the Societ the Society into effoet

\section{t}

$$
\text { of }
$$
of July 1860, and the 20th day of November 1860, and the 1st day of March 1861, respectively entered into between the said Commissioners and the firstmentioned Society, and in particular shall or may proceed to raise the said sum of $£ 40,000$, which by the first-mentioned Articles of Agreement is mentioned to be intended or to be then about to be raised by debentures, or such part or parts thereof as has not now already been or for the time being shall not have been raised, and also when and as the said Council shall think

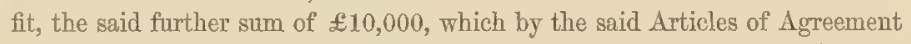
of the 1st day of March 1861, the said Council are to have liberty to borrow, or any part or parts thereof, and shall or may from time to time raise again or re-borrow any part or parts or sum or sums of money, in respect of any money which shall at any time or from time to time be paid off or discharged, of or in respect of the said sums of $\mathfrak{\&} 40,000$ and $\mathfrak{£} 10,000$, or any part thereof respectively, and shall or may for the purposes aforesaid, or any of them, or by way of security to the lenders, issue and deliver such debentures or other securities on behalf of or upon the property of "the Society" as the Council shall think fit, and without incurring any personal responsibility on account or in respect of the moneys now already raised or so to be raised or borrowed or raised again or re-borrowed, or by virtue of or under such debentures or securities, or in anywise howsoever in respect thereof, or of the matters aforesaid, or any of them; and We do hereby declare and grant that neither the Council of "the Society" nor any persons acting for or on behalf of "the Society" in the matter of the arrangement and the several Articles of Agree-

same shall, according to the rules or regulations of "the Society," become
due or payable, or shall neglect or fail in the observance or performance of the same rules or regulations in anywise, then such non-payment, neglect, or as a forfeiture by the Fellow so making defanlt as aforesaid of his rights and privileges as a Fellow or Memaber of "the Society," and in case of any resolupurpose, and generally for carrying into effect and performing on the part of ment, shall be personally responsible on account or in consequence thereof 

days nor more than ten days from the original meeting, for taking or continuing such ballot, of which adjourned meeting, and of the object thereof, notice shall be given in some newspaper circulating in London two days at least before the day of such adjourned meeting.

17. And, lastly, every annual meeting shall be deemed a general meeting,

Annual meeting
shall bo deemed a general one and the Council may call at any time and from time to time any other general meeting of the Fellows of the Society. In case of a ballot under the 13th and 16th clauses respectively, the ballot shall be taken at an adjourned meeting on some day to be appointed at the general meeting at which the same shall be required within ten days next after such general meeting between the hours of twelve o'clock at noon and three in the afternoon. In Witness whereof We have caused these Our Letters to be made patent-

Witness Ourself at Our Palace at Westminster this Eighth day of May in the 24th year of Our reign.

\section{Agreements between Her Majesty's Commissioner's for the Exhibition of 1851 and the Horticultural Society for the Lease to the Society of a portion of the Commissioners' estate at Kensington Gore.}

\section{ORIGINAL AGREEMENT.}

Pห⿻iเu1\}le.

ARTTCLES of AGREEMEXT made this 24th day of July in the year of our Lord 1860, between the Commissioners for the Exhibition of 1851 (hereinafter referred to as "the Commissioners "), of the one part, and the Horticultural Society of London (hereinafter referred to as "the Society") of the other part. Whereas the Society being desirous of obtaining a suitable area in or near the metropolis for an ornamental garden, in which they may exhibit and display the progress of Horticulture, and to which they propose to admit not only their Members and the holders of transferable tickets to which certain Life Members are and will be entitled, and also the holders of such debentures as are hereinafter mentioned (without any payment), but other visitors on payment (by such visitors) of fees for admission, have applied to the Commissioners for a lease for that purpose of a portion of their estate at Kensington Gore hereinafter described; and the Commissioners, being satisfied that the intended operations of the Society will extend the influence of the Science and Art of Horticulture npon productive industry, and that the formation of the said garden will be beneficial to their neighbouring property, have agreed to grant such lease on the terms hereinafter appearing. And whereas it has been agreed that certain earthworks for altering the levels of the land to be demised, as well for the permanent improvement thereof as for facilitating the operations of the Society, and certain arcades on the bound- 
NEW CHARTER AND AGREEMENTS.

aries of the said land which as to some of them or some part or parts thereof shall be leased to the Society as hereinafter mentioned, and as to others or other part or parts of such arcades, shall or may be used by the Society as hereinafter mentioned, and may be available for other improvements on the estate of the Commissioners, and which may be connected with buildings which the Commissioners may hereafter cause or allow to be erected on their estate, should be formed and erected at the expense of the Commissioners, and that the other works upon the ground to be demised should be constructed and done at the expense of the Society. And whereas the land proposed to be demised as aforesaid is that piece or parcel of land at Kensington Gore, in the county of Middlesex, containing 20 acres or thereabouts, the abuttals and boundaries of which, and the sites of the proposed erections thereon or connected therewith, are particularly delineated on the plan hereunto annexed, and the Commissioners have caused to be commenced the earthworks hereinbefore mentioned. And whereas the Society, for the purpose of defraying the expense of the works to be done by them on the premises to be demised, have entered into engagements for raising the sum of $£ 40,000$ by debentures, the residue of the sum of $£ 50,000$ (the amount agreed to be expended by the Society) having been obtained by them by donations and fees on the admission of Members for life. Now it is hereby mutually coveranted and agreed between the Commissioners and the Society, each covenanting for alt matters and things to be done and forborne by them respectively as follows :-

1. The Society shall, immediately after the execution of the earthworks which have been commenced as aforesaid, enter upon the said land for the purpose of laying out and constructing, and will forthwith lay out and construct an ornamental garden, with walks, trees, shrubs, terraces, steps, fountains, band-houses, statues, and vases, and in addition thereto with a conservatory or winter garden at the north end. The Society may also erect on the said land such offices and other buildings as may be necessary and convenient for the carrying on the affairs and business of the Society. The whole of the above-mentioned works to be done to the satisfaction and subject to the approval of the Commissioners ; and the said ornamental garden, with the works connected therewith, to be in a state fit for opening to visitors within six months after the Commissioners shall have finished the arcades hereinafter referred to. The Society will expend in laying out and construtting the said garden, with the works and buildings aforesaid, a sum of not less than $£ 50,000$.

2. The Commissioners, simultaneously with the progress of the works hereby undertaken by the Society, will at their own cost enclose the said ground with arcades of an architectural character, as indicated in the said plan. As respects the upper arcades coloured orange in the said plan, such arcades shall be substantial and finished buildings. But as respects the central and lower arcades, coloured blue and yellow in the said plan, the same
Preamble continued) 
APPENDIX.

may be of a more temporary nature. The Commissioners will expend the sum of $£ 50,000$ in and upon such earthworks as aforesaid, and in erecting the said arcades.

3. If the Society shall complete the works undertaken by them as

Commissioners to grant a expressed in the first clause of this Agreement, the Commissioners will grant to the Society a lease of the land and the garden and of the erections to be made or built thereon by the Commissioners and the Society respectively, as after-mentioned, for a term of 31 years, to be computed from the lst day of June 1861, on the terms and conditions following.

Buildings which are to be included

4. The buildings to be included in the lease shall be all such as are to be erected by the Society, and also the said upper arcades, except the parts coloured green in the said plan. The said excepted parts of the upper arcades, and the central and lower arcades shall not be so included, but shall remain the absolute property of the Commissioners, subject to a right of way Right of way and promente portions of the arcades not include in lease.

Right to erect stalls Commissioners, with such access may bo allowed by Society. or promenade therein or therennder during the continuance of the said lease, to be allowed to the Society and their visitors in such mode and to such extent nevertheless as respects the lower arcades, as not to prejudice or prevent the erection or letting of stalls in such lower arcades by and for the benefit of the Commissioners, which privilege, and the granting to the occupiers of stalls (but not to strangers, unless by payment by or for them to the Society of the usual charge for the admission of strangers to the gardens on the day on which snch right shall be enjoyed, ) right of way thereto by such access as may from time to time be appointed by the Society, the Commissioners expressly reserve to themselves; and the Commissioners also reserve to themselves the moneys received from such occupiers in respect of the stalls; and such moneys are not to be considered for the purpose of the provisions hereinafter contained as receipts from the garden, but shall belong wholly to the said Commissioners. And the said Society is not, without the consent of the Committee hereinafter mentioned, in any of the arcades to be demised to them, to let any part thereof for stalls or the sale of any matters (except refreshments). And with respect to the sale of refreshments, the sale thereof in the arcades to be demised to the Society shall continue only until suitable permanent arrangements for the supply of the refreshments shall (with the consent of the Society) have been made by the Commissioners.

5. It is understood that the Commissioners or their assigns are to have Cornmissiuner's to

to arch ove entrances

into garden. full power to arch over, if they should think fit, all or any part of the entrances or ways into the garden, for the purpose of erecting over the space thereof any buildings, and to erect for the purposes of the arches, or of the superstructure, piers or columns on any part of the ground appropriated to such entrances or ways, so far as the same may be done without obstructing the convenient access to the garden so far as respects the entrance on the west side ; and in regard to that on the east side, so far as may not interfere with the meeting rooms and offices proposed to be erected there by the Society;

Right is and the demise and grant of rights to the Society, of or in respect of the 
NEW CHARTER AND AGREEMENTS.

arcades, is not to prejudice the right of the Commissioners to erect, or allow to be erected, any superstructure on or building connected with the arcades, (except that no superstructure shall be erected on the demised part of the upper arcades), or to take down any of such arcades for the purpose of erecting others of a more substantial or different character, and to suspend, so far as may be necessary, during the progress of such works the right of promenade, and use by the Society of such arcades.

6. No buildings shall be erected by the Society during the said lease without the sanction of the Commissioners, except strictly temporary buildings.

7. The Society shall keep in good repair all buildings to be included in the said lease, and all other the buildings which may be erected on the land to be demised, except the excepted parts of the upper arcades and the central and lower arcades, and the buildings by the Commissioners mentioned in Clause No. 5, which last-mentioned arcades and buildings shall be kept in good repair by the Commissioners ; and the Society shall, at the end of the term, give up such buildings except as aforesaid, in good repair, together with all the statues and works of Art which may be placed or put up in the gardens, and with all fixtures, including conservatories, greenhouses, and other erections at any time put up on the ground, and with all shrubs, trees, and plants that may be growing thereon: Provided that the Society be at liberty to remove all statues and works of Art, temporary conservatories, greenhouses and other temporary structures put up by them, or with their consent, and paid for out of their own funds, after the commencement of the said term (except in the cases where the payments for such statues or works, conservatories, greenhouses, or other structures, shall have been allowed to them out of, or as part of, the current expenses of the said garden, by the Committee hereinafter mentioned).

8. The Society shall use the demised premises for the purpose for which they have applied for the lease of the same as hereinbefore expressed, and for no other ; and if, in the management or dealings with the demised premises, the Society do or propose any act, matter, or proceeding which, having regard to the terms and stipulations of these presents, shall, in the judgment of the Commissioners, be held unreasonable, and be deemed to be prejudicial to the demised premises, or the other property of the Commissioners, or to their rights, the Commissioners shall have full power to prohibit the act, matter, or proceeding in question, and the Society shall abstain or forthwith discontinue the act, matter, or proceeding so prohibited.

9. The Society shall insure from loss by fire all such of the buildings to Society to be erected on the premises demised as the Society is under Clause No. 7 insure from bound to repair.

10. The Society shall not assign, underlet, or otherwise part with the lease Society not to be so granted, or the premises to be so demised, except with the consent in writing of the Commissioners.

11. All moneys received from Fellows of the Society, who have already to anderigu without sanction of Commit
stoners. 213

G 0 


\section{APPENDIX.}

Whint moneys to be cupital.

signified their intention of compounding, and who have paid or shall pay such composition, and all sums received from new Life Members elected prior to the 1st day of June, 1861, shall be considered capital, and belong to, and may be invested or used by the Society for the purpose of redeeming outstanding debentures, or otherwise.

12. The Society shall cause to be kept an account of all moneys received Iccoints to be kept by
Society. by them in respect of the admission to the gardens, and of all moneys received by them from Members for annual subscriptions (not compositions from Fellows nor life-memberships) received or subscribed for subsequent to those which are included in the amount of $£ 50,000$ mentioned in the recital to these presents, and all moneys paid or to be paid for admission of any person to the Society on terms conferring any right of entering the gardens, all which moneys and such proportion or annual sums from time to time as hereinafter mentioned, of or in respect of the moneys received for compositions from Fellows who shall, after the execution of these presents, signify their intention of compounding, and for life-memberships of Fellows elected after the said 1st day of June, 1861, are to be considered and are hereinafter referred to, as "receipts from the gardens," and such accounts shall be rendered, and the rents hereinafter stipulated for, so far as they can be ascertained, paid half-yearly to the Commissioners.

13. With respect to moneys received for compositions from Fellows, who, after the execution of these presents, shall signify their intention of compounding, and for life-memberships of Fellows elected after the said 1st day of June, 1861, the same shall be accounted for and disposed of in manner following (viz.), the annual receipts of the Society from such compositions from Feliows and from such Life Members as last aforesaid, shall be taken in making out the account above referred to according to the number of such Fellows and Members respectively in existence at the commencement of each financial year, and at the rate for each of such Fellows and Members respectively, of one-fifteenth of the sum which he may have paid for composition, or in lieu of annual payments, or for admission, namely, at the rate of $£ 216 s$. for each Fellow or Member who may have paid $\mathfrak{£} 42$, and at the rate of $\mathfrak{£} 18$ s. for each Fellow or Member who may have paid $£ 21$, and the Society shall be charged in such financial year with such "annual receipts" as part of the "receipts from the gardens ;" and subject to the stipulation in the present clause, all sums of money paid to the Society for the composition of annual payments by Fellows, and for the admission of Fellows as Life Members, may be applied and disposed of as part of the general funds of the Society, or in such manner as the Society shall think fit.

nisposal of 14. Out of the gross amount of the "receipts from the gardens" there moneys shall be first retained by the Society such a sum as shall from time to time be allowed by the Committee hereinafter mentioned, in respect of the expenses of the Chiswick garden, or other garden in lieu thereof, to be kept up for 1. In pay. experimental or scientific purposes, the reasonable expenses of the manage- 
NEW CHARTER AND AGREEMENTS.

mont of the Society, including the expenses of the exhibition in the demised (ox) went if grounds (or elsewhere, with the consent of the Commissioners) of flowers, expwsiss. fruits, and other articles; bands, police, and other general and necessary expenses; and also sums to be given for medals or prizes for competition for articles shown at such exhibitions; and further in respect of the current expenses of the gardens, to be laid ont and constructed under these presents, including the repairs to be done by the Society, costs of insurance and any structural or other improvements or ornaments which the Committee may think fit, which allowance shall from time to time proceed and be made upon a fair and reasonable basis, and so as to keep and maintain the said gardens and all the buildings, improvements, and ornaments upon and belonging thereto in thoroughly good order and condition. 2ndly. There shall be then retained by the Society out of such receipts, the amount which may be from time to time payable by the Society in respect of interest, not exceeding 5 per cent., on the sum of $£ 40,000$ which they have borrowed on debentures as aforesaid, or on so much of the said sum of $£ 40,000$ as may remain unpaid or undischarged; and, 3rdly. There shall then be paid by the Society to the 3. In mas said Commissioners as rent, the yearly sum of $£ 2,145$, if the receipts shall be Rent. adequate for such payment after retaining to the Society the sums authorised to be retained by them under the 1 st and 2 nd heads of the present clause, but otherwise such a sum only as shall be equal from year to year to the residue of the receipts over and above the sums so in precedence. And if there shall remain any surplus over and above the said several payments hereinbefore directed to be made or retained out of the "receipts from the gardens," there shall be paid to the Commissioners for their own use and as additional rent yearly, a sum equal to half such surplus.

15. For the purpose of regulating the amount to be retained by the Exyemke: Society in each year for expenses, a Committee shall be appointed annually, which Committee shall consist of six persons, three of whom shall be appointed by the Commissioners, and three by the Society, and any three of such Committee shall form a quorum, so as one at least shall be a person appointed by the Commissioners, and one a person appointed by the Society. Seven days' notice of every meeting of the Committee shall be given in writing to each member of the Committee by a letter to be sent by the post. As vacancies may occur in each year by death, incapacity, or resignation, such vacancies may be filled up respectively by the Commissioners or the Society according as the original appointments were made by them respectively.

16. The Committee shall from time to time select one of those Committeemen who have been appointed by the Commissioners as Chairman of such Committee, which Chairman shall have the power of voting on all occasions equally with the other Committeemen for the time being, acting; and such Chairman, in case of equality, to have a casting rote in addition; and the Committee shall have power to make bye-laws for their own government in the execution of the duties confided to them.

utiminite. 4. Division
of the surphis. 3. In paylent of centares 215

1. 1.2 


\section{APPENDIX.}

Society to apply three fifths of

their share debentures Consefailure tu

Commis sioners' title accepted as

Renewal of Rene

Condition on which

sommis-

deeline to rencer.

17. The Society shall devote and apply towards the liquidation of the debt of $£ 40,000$ (being the amount which they have so raised by debentures as hereinbefore recited), three-fifths of the money actually received by them from time to time in respect of the "receipts from the gardens," after the payments directed to be retained out of the said receipts for expenses and interest by the Society, and the rent to the Commissioners.

18. In case it shall happen, after the expiration of the first five years of the lease, that the sum or sums payable thereunder to the Commissioners as rent, shall fail in every one of any five consecutive years subsequent to the first five years to be equal to the sum of $£ 2,145$ per ammum, then, and in any such case, it shall be lawful for the Commissioners to re-enter upon the said demised premises, and to resume full and absolute possession thereof, with all improvements therein, and all erections thereon, and with all the plants, shrubs, and trees in and about the same, and out of whatever fund the same may have been paid for, and that without making any compensation whatsoever to the Society. Provided always, that the right of re-entry shall not arise if the Commissioners, from the commencement of the term, have under the aforesaid provisions, received such a sum of money for rent as would, reckoning from such commencement to the expiration of the last year in which such continued deficiency shall occur, amount to an average sum of $£ 2,145$ per annum.

19. The Society shall not require the Lessors' title to be deduced, nor shall any objection be made on the ground that a part or the whole of the ground to be demised is on mortgage, and that the mortgagees do not concur.

20. The Society shall have the right of giving to the Commissioners, two years before the expiration of the term of 31 years (provided such lease shall not have been previously determined or become subject to be determined under the proviso for re-entry hereinbefore mentioned or contained), a notice in writing calling upon the Commissioners to renew the lease to be so granted for a further term of 31 years, to commence at the expiration of the first term of 31 years, subject to all and every the terms and conditions on which the original term is to be granted, except the right of renewal, and except as hereinafter appears. And in case of such notice being given, the Commissioners (provided the original term shall not have become liable to forfeiture after the giving of such notice) will either grant a renewal in accordance with such notice and these presents, or, at their option, may decline to grant such renewal on the terms and conditions of their taking upon themselves at the end of the original term of 31 years, the payment of such amount of the original debenture debt of $£ 40,000$ as may remain unpaid and undischarged at the expiration of that term, provided such amount do not exceed $£ 20,000$, or upon condition of taking upon themselves the payment of $£ 20,000$ part of such debt, if there remain owing a larger sum than $£ 20,000$ at the expiration of such term, which sum of $£ 20,000$ so to be paid by the Commissioners shall be applied in discharge or satisfaction of the unpaid debentures for the time being rateably and without preference 
NEW CHARTER AND AGREEMENTS.

or priority. If, on the other hand, the debenture debt shall at the expiration of such term be less than $£ 15,000$, or in case there should be no part of the said debenture debt then owing or unpaid, the Commissioners, in the former case, shall pay to the Society such a sum as when added to the amount of debenture debt then owing or unpaid, shall constitute a total sum of $£ 15,000$; and the Commissioners shall in the latter case pay to the Society the full sum of $£ 15,000$; and the Commissioners shall make their election to renew or take upon themselves such payment within six calendar months from the receipt of the notice requiring a renewal. If the Commissioners elect to renew, a renewal shall take place accordingly, but the proviso for reentry shall be so framed as to operate immediately and without a suspension of the first five years of the renewed term.

21. If the Commissioners elect not to renew, they shall give a bond under their common seal to the Society, to secure the due performance of the obligation which they are to undertake in respect of the portion of debt of the Society, not exceeding $£ 20,000$ remaining unpaid, or of the payment of the sum not exceeding $£ 15,000$ as aforesaid, as the case way be, in which bond some certain day, not being more than 12 months from the date thereof, shall be named for the principal sum of money thereby conditioned to be paid, and in the meantime interest at the rate of $£ 5$ per cent. per annum shall be payable thereon.

22. The costs of the original lease and counterpart, and of any renewal, and of these presents shall be paid by the Society.

23. If either of the parties hereto shall differ as to the construction of the

Costs of lease and renewal. to Society. terms and provisions herein contained, or the mode in which this present Differences to be settled agreement is to be executed, or as to the provisions to be contained in any by arbitrallease to be granted in pursuance of these presents, then all questions in ion. difference shall, on the application of either party, be determined by an arbitrator to be named in writing by Her Majesty's Attorney-General for the time being: and the decision of such arbitrator in writing, within the time, and as shall be directed by the said Attorney-General, shall be binding on all parties. In witness whereof, the Commissioners and the Society have hereunto affixed their Common Seals above written.

SUPPLEMENTAL AGREEMENT.

Articles of AgReEment made this 20th day of November in the year of Preamble. our Lord 1860, between the Commissioners for the Exhibition of 1851 (hereinafter referred to as "the Commissioners") of the one part, and the Horticultural Society of London (hereinafter referred to as "the Society") of the other part. Whereas by certain articles of agreement bearing date the 24th day of July 1860, and made between the Commissioners of the one part and the Society of the other part, it hath been covenanted and agreed between

217 


\section{APPENDIX.}

Prenmlle the Commissioners and the Society that certain works shall be done and (continuted). executed by the Commissioners and the Society respectively in and upon a piece of land part of the estate of the Commissioners at Kensington Gore, which piece of land is agreed and intended to be used as an ornamental garden in which may be exhibited the progress of Horticulture, and which land is hereinafter referred to as "the gardens," and that on certain terms and subject to certain conditions therein specified a lease of the gardens should be granted by the Commissioners to the Society renewable as therein mentioned. And whereas the intended works are now in progress; and whereas the Society require for purposes connected with their said undertaking the use of some additional land adjoining or near "the gardens," and the Commissioners have allowed the Society to take and have possession for such purposes of certain land adjoining the gardens which is shown on the plan hereunto annexed and specified by a red colour, and which land is hereinafter referred to as " the additional land," but the Commissioners have declined to include such land in the lease to be granted, as they may require to resume possession of the same for other purposes; and whereas an access to the gardens is at present afforded by means of a lane or path shown on the said plan and marked with the colour brown, but the Commissioners have declined. to include in the lease the use of such way, as it might interfere with other arrangements to be made by them of and concerning other parts of their estate at Kensington Gore; and whereas with \& riew to the mutual convenience of the Commissioners and the Society, it hath been agreed to make and enter into this agreement as supplemental to the said recited agreement of the 24th day of July 1860: now it is hereby mutually covenanted and agreed between the Commissioners and the Society, each covenanting for all matters and things to be done and forborne to be done by them respectively as follows, viz. :-

Additional 1. The Society shall have and continue to hold possession of the additional land, viz.g of all that piece of ground shown in the plan hereto annexed and marked with the colour red, as tenants thereof from year to year under the Commissioners, such tenancy to be held and understood as commencing on the 24th day of June last, until the Commissioners shall think fit to resume

Leise terThinable on six nontins either side. possession of the same, which they shall be at liberty to do at any period of the year without reference to that on which the tenancy commenced, on giving six calendar months' notice in writing of their intention so to do, and subject to the stipulations and conditions hereinafter contained; or the Society may give up the same on six months' notice at the end of any current year of their tenancy.

2. The Society shall build thereon a gardeners house, an engine-house, tardeners hourse, engine-house, and other buildings to thereon, subject to subject to tanks, and other buildings required for the purpose of the said undertaking, with the necessary works and appliances, but no other erections or buildings whatsoever, and all such buildings except strictly temporary buildings, shall be erected in accordance with plans previously submitted to and approved by 
NEW CHARTER AND AGREEMENTS.

the Commissioners, and shall be completed to their entire satisfaction, or otherwise the Society shall not be entitled to the benefit of this agreement; and the said additional land shall be used only for the purposes of the said undertaking, and shall not be underlet or assigned by the said. Society to any person or persons whorasoever, and shall not be so used as to allow the public or any other person or persons to obtain any rights or easements over the same that can or may in any way interfere with the use thereof by the said Commissioners for any purposes or purpose whatsoever ; and the Society will, at the request of the Commissioners, do and allow to be done all acts and things the Commissioners may think necessary to prevent any such rights or easements being obtained.

3. Until the Commissioners shall resume possession of the said additional Rent, 18. land under the provisions in that behalf hereinbefore contained, the Society will yearly pay to the Commissioners the rent of $1 s$. as an acknowledgment of the tenancy of the said land and of the use of the easement hereinafter agreed to be granted to them, the first yearly payment to be made on the 24th day of June 1861.

4. The Society shall, so long as the Commissioners think fit, have a right to use the road or way specified by the colour brown on the said plan as an access to the gardens, and the Commissioners shall not stop up or interfere with such right unless and until they shall provide another road for the use of the Society in lieu thereof; and in case the Commissioners think fit to stop the said access to the said gardens, the said Commissioners shall find and provide some other fit access to such gardens, which access they shall be at liberty nevertheless from time to time to alter as they shall think fit.

5. In case the Commissioners shall desire to resume possession of the additional land and the Society shall continue at the time of the service of the six months' notice entitled to the lease agreed to be granted to them under the said agreement of the 24th day of July 1860 (such lease not being forfeited or liable to forfeiture), the Commissioners shall, before the expiration of such notice, appropriate for the use of the Society, as tenant from year to year, and subject to like provisions to those herein contained, some portion of their estate at Kensington Gore convenient for the purposes for which it is intended to use the additional land; and also that they the said Commissinners shall and will within the period of six months after service of such notice, and at their cost and expense, reinstate upon the land to be so appropriated as aforesaid the buildings and works as nearly as possible in the same condition as the buildings and works erected on the additional land.

6. All land to be substituted for the additional land shall be held by the Society, subject to all the stipulations herein contained, particularly the right of the Commissioners again to resume possession thereof on terms similar to those herein specified as regards the additional land, and nothing herein

Society's right of gardens.
Commit-

lowers

Society not to underlet, or allow ensernents to be ob 


\section{APPENDIX.}

particular portion of the estate of the said Commissioners, so as to prevent them doing as they may think fit with their said estate.

7. The Commissioners shall have foll power and absolute right to take

Commisright of resimption without compons tion if commit a forfoituro. and resume possession, without paying any compensation whatever, of all the additional land for the time being appropriated for the purposes of the said Society as aforesaid, and all erections and buildings thereon, in case the Society shall do or commit any act or default which would be or amount to a forfeiture of the lease agreed to be granted to them by the said agreement of the 24th day of July 1860 ; and in the event of such forfeiture such possession may be taken without the six months' notice; and they may also, in the event of the Society doing or committing any such act or default, stop up the aforesaid access altogether without any such notice.

8. The Society shall, so long as any tenancy shall continue under this Society to and taxes for this addiagreement, either as regards the land, the immediate subject matter thereof, or any other land to be appropriated in lieu thereof, pay all rates and taxes payable in respect of such land, and keep the same in good order and condition, and shall insure and keep insured all buildings and erections thereon, and shall keep such buildings and erections in good and tenantable repair, and generally in all cases not hereby expressly provided for, the said land hereby agreed to be let and any laad to be substituted for it shall be used and dealt with as if comprised in the agreement of the 24 th day of July 1860 , or in the lease to be granted pursuant thereto.

9. If either of the parties hereto shall differ as to the construction of the terms and provisions herein contained, or the mode in which this present agreement is to be executed, or as to what might or ought to be done or forborne in pursuance or by virtue of or under the terms and stipulations herein, or in reference to any other matter or thing arising under these presents, then all questions in difference shall, on the application of either party, be determined by an arbitrator to be named in writing by Her Majesty's Attorney-General for the time being, and the decision of such arbitrator in writing within the time and as shall be directed by the said Attomey-General shall be binding on all parties. In witness whereof the said Commissioners and the said Society have hereunto affixed their Common Seals above written.

\section{SECOND SUPPLEMENTAL AGREEMENT.}

Preamble.

Articles OF Agremuent made the 1st day of March in the year of our Lord 1861, between the Commissioners for the Exhibition of 1851 (hereinafter referred to as "the Commissioners") of the one part, and the Horticultural Society of London (hereinafter referred to as "the Society") of the other part. Whereas, by certain articles of agreement bearing date the 24th day of July 1860 , and made between the Commissioners of the one part and the Society 
NEW CHARTER AND AGREEMENTS.

of the other part, it was mutually covenanted and agreed between the Com-

Preamble missioners and the Society that certain works should be done and executed by (continued) the Commissioners and the Society respectively in and upon a certain piece of land, part of the estate of the Commissioners at Kensington Gore, which piece of land is agreed and intended to be used as an ornamental garden, and is in the now reciting agreement, as well as hereinafter, referred to as "the gardens;" and that, on certain terms and subject to certain conditions therein specified, a lease of the gardens should be granted by the Commissinners to the Society for the term of 31 years computed from the dst day of June 1861, renewable as therein mentioned. And whereas it was by Clause 1 of that agreement provided that the Society should expend in laying out and constructing the said gardens, with the works and buildings in the said agreement in that behalf specified, a sum of not less than $£ 50,000$; and it was by Clause 2 of that agreement provided that the Commissioners, subject to the conditions therein mentioned, should expend the sum of $£ 50,000$ in and upon the works by them to be done in accordance with the said agreement. And whereas it is provided by Clause 14 of the said agreemont that out of the gross amount of the receipts from the gardens certain expenses therein mentioned should be retained by the Society; and, secondly, that there should be then retained by the Society the amount which might be payable by the Society in respect of interest not exceeding $£ 5$ per cent. on the sum of $£ 40,000$, which it appears by the recitals therein contained they had borrowed or arranged to borrow on debentures, or on so much of that sum as might remain unpaid or undischarged; and, thirdly, there should be paid by the Society to the Commissioners, as rent, the yearly sum of $£ 2145$, if the receipts should be adequate for such payment after retaining to the Society the sums authorised to be retained by them under the first and second heads of that clause, but otherwise such a sum only as should be equal from year to year to the residue of the receipts over and above the sums so in precedence, and if there should remain any surplus over and above the several payments thereinbefore directed to be made or retained out of the receipts from the gardens, there should be paid to the Commissioners for their own use, and as an additional rent, yearly; a sum equal to half such surplus. And whereas Clause 17 of such agreement provides that the Society shall devote and apply towards the liquidation of the debt of $£ 40,000$ three-fifths of the money actually received by them from time to time in respect of the receipts from the gardens after the payments directed to be retained out of such receipts for expenses and interest by the Society, and the rent to the Commissioners ; and it is by the 18th Clause of such agreement provided that the Commissioners shall have a right of reentry in certain events in case of such continued nonpayment of the rent of $£ 2145$ as therein mentioned. And whereas it is provided by the 20th Clause of such agreement that the Society shall have a right to give such notice as therein mentioned, calling for a renewal of the lease to be granted to them, and the Commissioners may either grant such

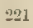

H $\mathrm{H}$ 


\section{APPENDIX.}

Preamble (continued) payment of such amount of the original debenture debt of $£ 40,000$ as should
remain unpaid and undischarged at the expiration of that term, provided such amount do not exceed $£ 20,000$, or upon condition of taking upon themselves the payment of $£ 20,000$ part of such debt, if there remain owing a larger sum than $£ 20,000$, with a provision that if the debenture debt shall be less than $£ 15,000$, or in case no part of the debenture debt shall be then unpaid, the Commissioners would pay a sum of $£ 15,000$ in manner and for the purposes in that clause mentioned. And whereas the Society and the Commissioners are each desirous of respectively having the right of increasing the outlay by them respectively undertaken to be made by the said agreement to any amount not exceeding as to each of them the sum of $£ 10,000$ over and above the respective sums of $£ 50,000$ by them respectively undertaken to be laid out as aforesaid, and of acquiring such rights and privileges as herein appear in respect of such additional outlay, if made. Now, it is hereby mutually covenanted and agreed between the Commissioners and the Society, each eovenanting for all matters and things to be done and forborne by them respectively, as follows :--

Society to have power
to borrow $£ 10,000$ additiona

1. That the Society may at any time before the 1st day of January 1864, if they think fit (bot they are not hereby required so to do, notwithstanding any additional outlay that may be made by the Commissioners), borrow and take up on their debentures or other securities, any sum or sums not exceeding in the whole the sum of $£ 10,000$, in addition to the sum of $£ 40,000$ in the agreement mentioned as having been borrowed, or for the borrowing of which arrangements had been made, and may within the like period lay out and expend the sum or sums so borrowed in addition to the original sum of $£ 50,000$ therein mentioned in and about such works and things as are in the 1st Clanse of the said recited agreement undertaken to be done by them, and in and about which the original sum of $£ 50,000$ is required by that clause to be expended, such additional sum or sums nevertheless being laid out and expended in such mode, and the works on which the same shall be expended to be subject to the like approval, as in that clause provided in respect of the sum of $£ 50,000$ as therein mentioned.

Commis.
sioners in sioners in to have

2. That the Commissioners may, if they think fit at any time before the 1st day of January 1864 (but are not hereby required so to do, notwithstanding any additional outlay that may be made by the Society), lay out and expend such sum or sums of money as they may think fit, not exceeding in the whole the sum of $£ 10,000$ in addition to the original sum of $£ 50,000$ in Clause 2 of the said agreement mentioned, in and about such works, matters and things, as by that clause are undertaken to be done by them, and in and about which the sum of $£ 50,000$ is required by that clause to be expended. by them.

3. In case both or either of the parties hereto think fit to make any such 222 


\section{NEW CHARTER AND AGREEMENTS.}

outlay, such parties respectively or party shall have no claim or demand either part against the other of them or against the gardens or against the receipts from fadditional the gardens save and except as hereinafter mentioned, viz., that with a view except as to compensate such parties respectively or party in some degree for such folluws: additional outlay, the following alterations shall be made in the said recited agreement, and in the lease to be granted pursuant thereto, viz. :-

4. The 14th Clause of the said recited agreement shall be altered and Altoration amended as follows, viz.s out of the gross amount of the receipts from the on (14) in first gardens there shall be first retained by the Society such a sum as shall from astodisposa time to time be allowed by the Committee mentioned in Clause 15 of the of ra, 1. Nosaid agreement in respect of the expenses of the Chiswick Garden, or other garden in lieu thereof, to be kept up for experimental or scientific purposes, the reasonable expenses of the management of the Society, including the expenses of the Exhibition on the demised gronnds (or elsewhere with the consent of the Commissioners), of flowers, fruits, and other articles, bands, police, and other general and necessary expenses, and also sums to be given for medals, or prizes for competition for articles shown at such Exhibition, and further in respect of the current expenses of the gardens to be laid ont and constructed under the said agreement, including the repairs to be done by the Society, costs of insurance, and any structural or other improvements or ornaments which the Committee may think fit, which allowance shall from time to time proceed and be made upon a fair and reasonable basis, and so as to keep and maintain the said gardens, and all the buildings, improvements, and ornaments upon and belonging thereto in thoroughly good. order and condition; secondly, there shall be then retained by the Society out of such receipts the amount which may be from time to time payable by the Society in respect of interest not exceeding 5 per cent. per annum on the sum of $\mathfrak{\$} 40,000$ originally borrowed or agreed to be borrowed by them on debentures as aforesaid, and on any further sum or sums they may borrow and expend in accordance with Clause 1 of this agreement not exceeding $£ 10,000$ or on so much of the original and additional sums as for the time being may have been raised and shall not have been paid off; and, thirdly, there shall ${ }^{8 . \text { Additional }}$ then be paid by the Society to the said Commissioners as rent the yearly sum or sums hereinafter in that behalf mentioned, if the receipts shall be adequate for such payment, after retaining to the Society the sums authorised to be retained by thera under the first and second heads of the present clause, but otherwise such a sum only as shall be equal from year to year to the residue of the receipts over and above the sums so in precedence, viz., if the Commissioners shall limit their outlay under Clause 2 of the said recited agreement to $£ 50,000$, then the yearly sum of $£ 2145$ only, but if under Clause 2 of this agreement they shall expend a larger sum, then an addition shall be made to such rent at the rate of $£ 458$. for every additional $£ 100$ which the Commissioners shall think fit to expend in accordance with that clanse, not exceeding $f 10,000$ in the whole. And if there shall remain any surplus over and above 4. Dirisive 


\section{APPENDIX.}

the said several payments hereinbefore directed to be made or retained out of the "receipts from the gardens," there shall be paid to the Commissioners for their own use, and as additional rent yearly, whether or not they make any additional outlay, a sum equal to half such surplus.

5. The 17th Clanse of the said recited agreement shall be altered as Three-fifths of surplus to liquidation
of deben. of deben-
tures. follows, viz, the Society shall devote and apply towards the liquidation of their debenture debt, whether it amount to the original sum of $£ 40,000$ only, or any increased amount under the authority of Clause 1 of this agreement, three-fifths of the money actually received by them from time to time, in respect of the "receipts from the gardens," after the payments directed to be retained out of the said receipts for expenses and interest by the Society and the rent to the Cormmissioners.

6. The 18th Clause of the said recited agreement shall be altered as

Conse-

Grenes of
failure to

pay rent

sultered to

tional sium

borrowed.

follows, viz, in case it shall happen after the expiration of the first five years of the lease, that the sum or sums payable thereunder to the Commissioners as rent shall fail in every one of any five consecutive years subsequent to the first five years, to be equal to the sum of $£ 2145$ per annum, in case only that sum. shall be payable, or to such larger amount as is hereby made payable as rent to the Commissioners, in respect of any additional outlay under Clause 2 of this agreement, if such increased rent become payable, then and in any such case it shall be lawful for the Commissioners to re-enter upon the said demised premises, and to resume full and absolute possession thereof, with all improvements therein and all erections thereon, and with all the plants, shrubs, and trees, in and about the same, and out of whatsoever fund the same may have been paid for, and that without making any compensation whatsoever to the Society; provided always, that the right of re-entry shall not arise if the Commissioners from the commencement of the term have, under the provisions herein or in the said recited agreement contained, received such a sum of money for rent as would, reckoning from such commencemement to the expiration of the last year in which such continued deficiency shall occur, amount either to an average sum of $£ 2145$ per annum (if only $£ 50,000$ shall have been expended by them), or (in case of an additional outlay by the Commissioners under the 2nd Clause of these presents) to an average sum equal to $£ 2145$ and interest of $£ 45$ s. per cent. per annum on the amount of such additional outlay.

7. Provided always that nothing herein contained or to be done under the authority of these presents shall alter or prejudice the rights of the respective parties under Clanse 20 of the said recited agreement, save and except that in estimating the debenture debt of the Society for which under that clause provision or compensation is to be made by the Commissioners, regard shall be had not only to the original debt raised by the Society, but to the increased or additional debt raised by the Society under the authority of these presents ; and in case the aggregate amount of those debts remaining unsatisfied shall exceed $£ 20,000$, the said Clause No. 20 shall be read as if the sum named for 


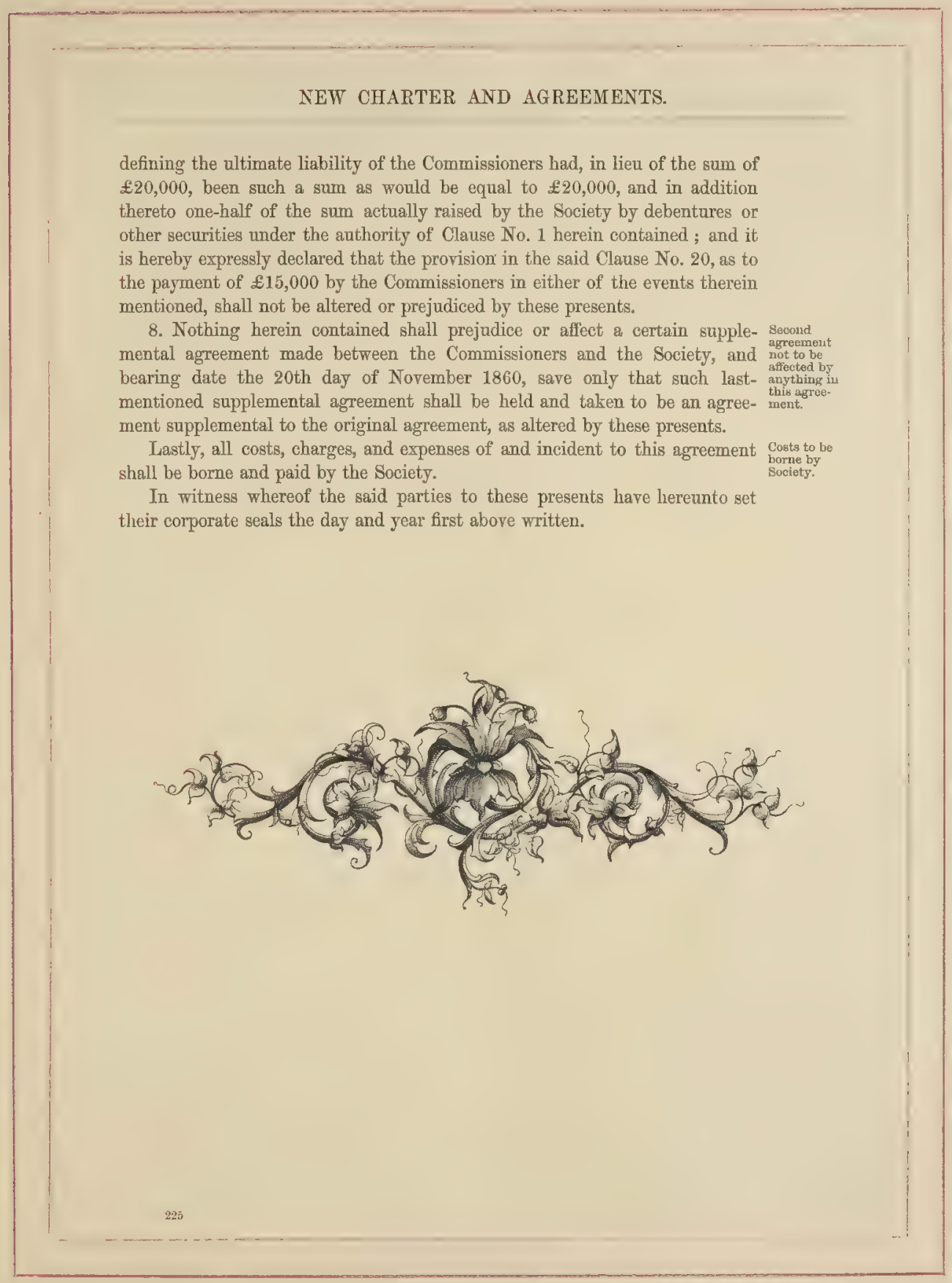




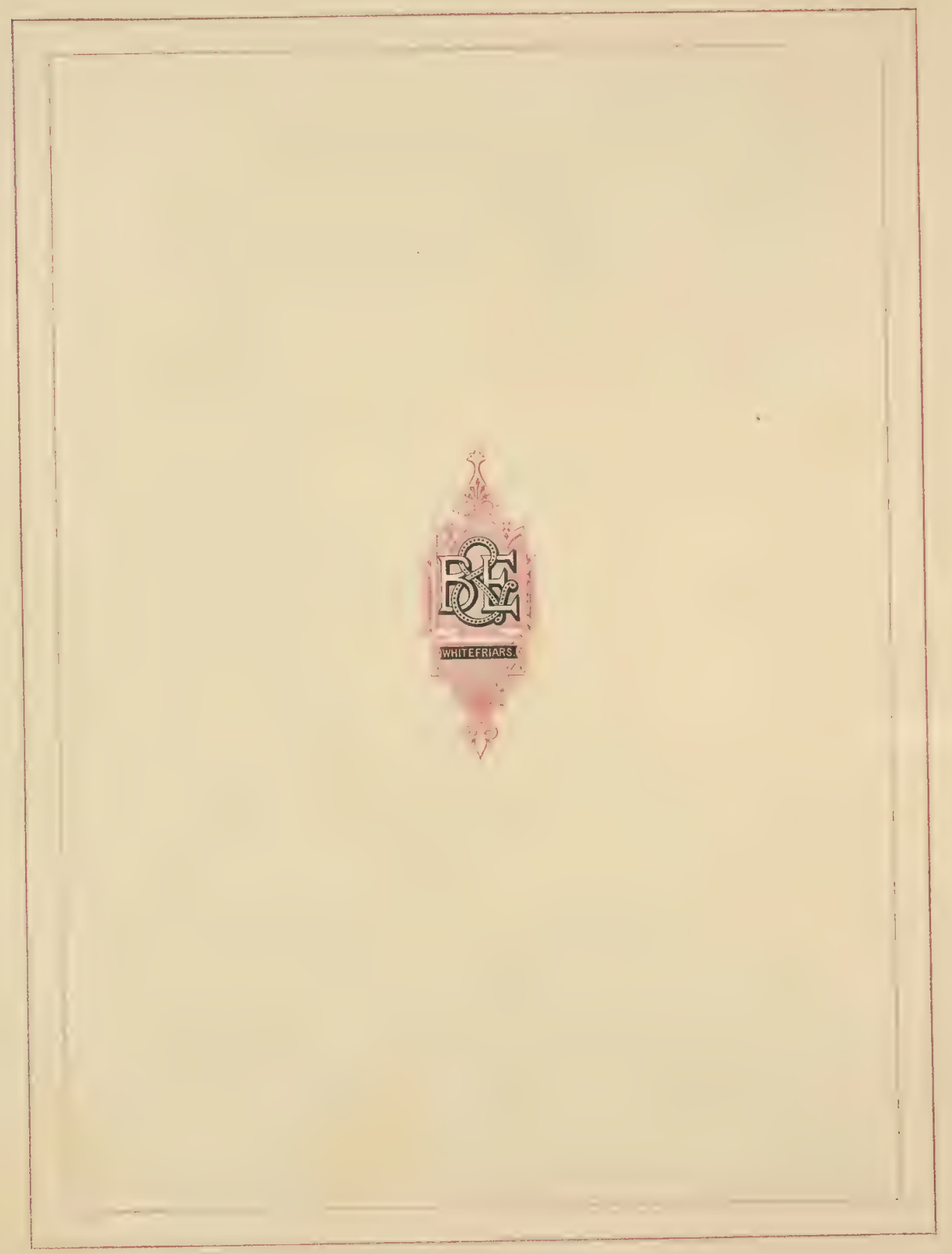




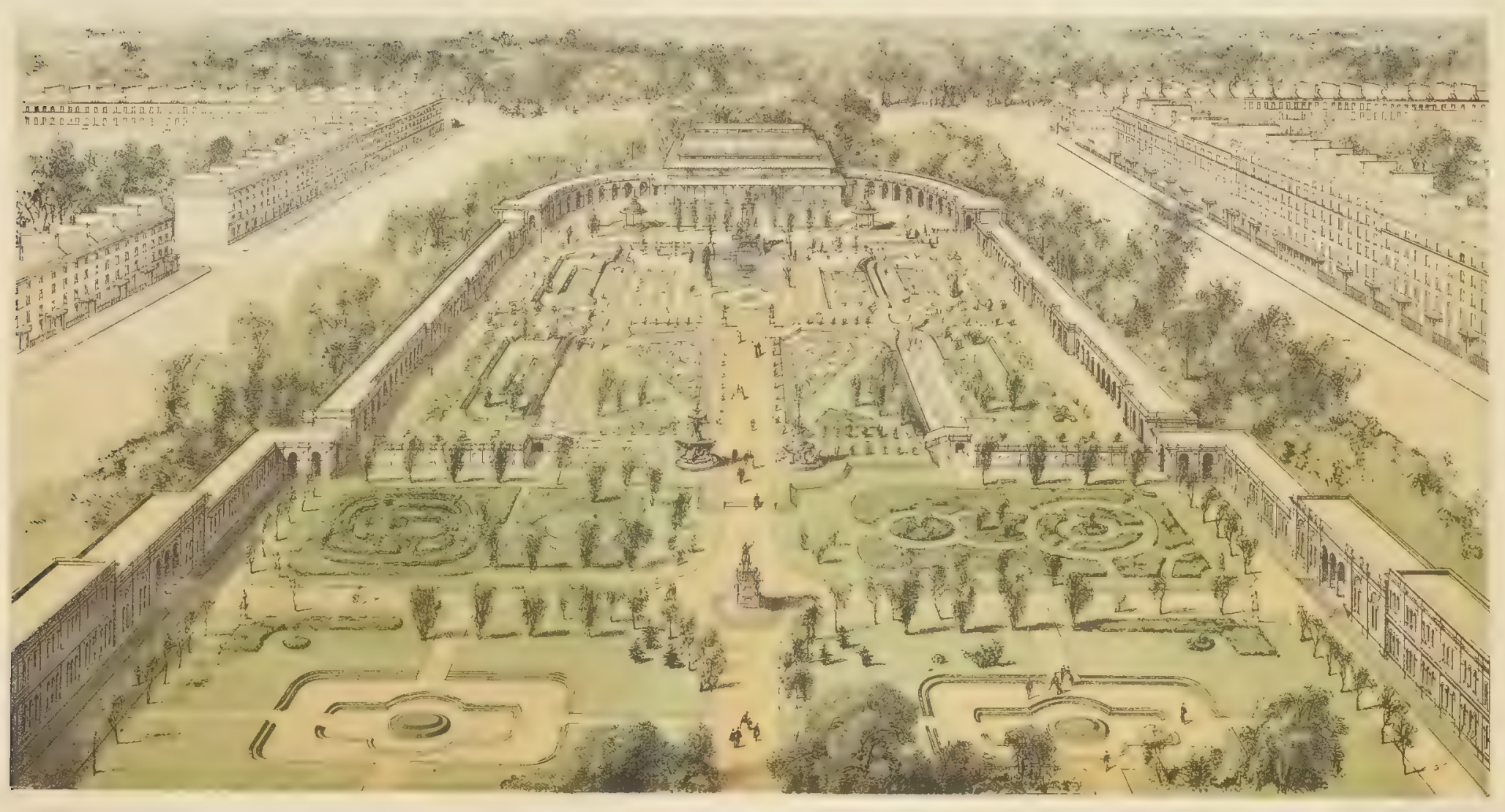



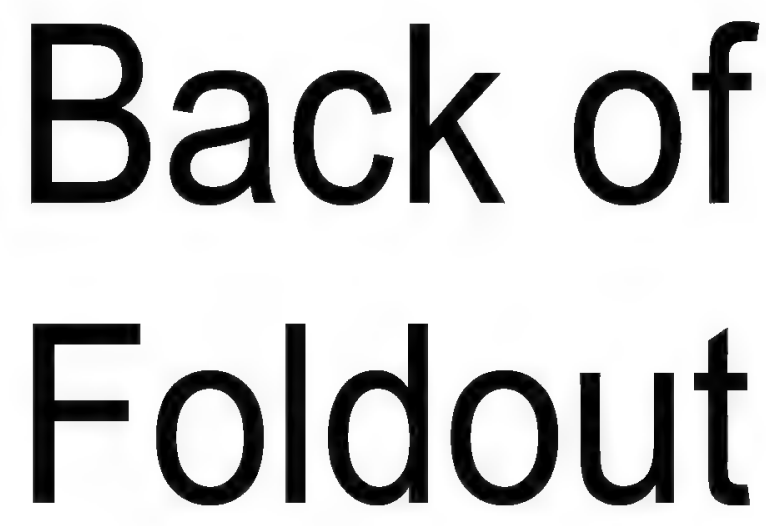

Not Imaged 



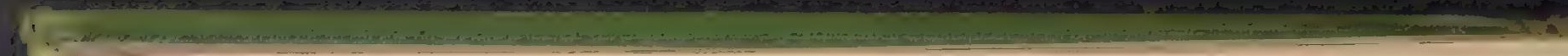






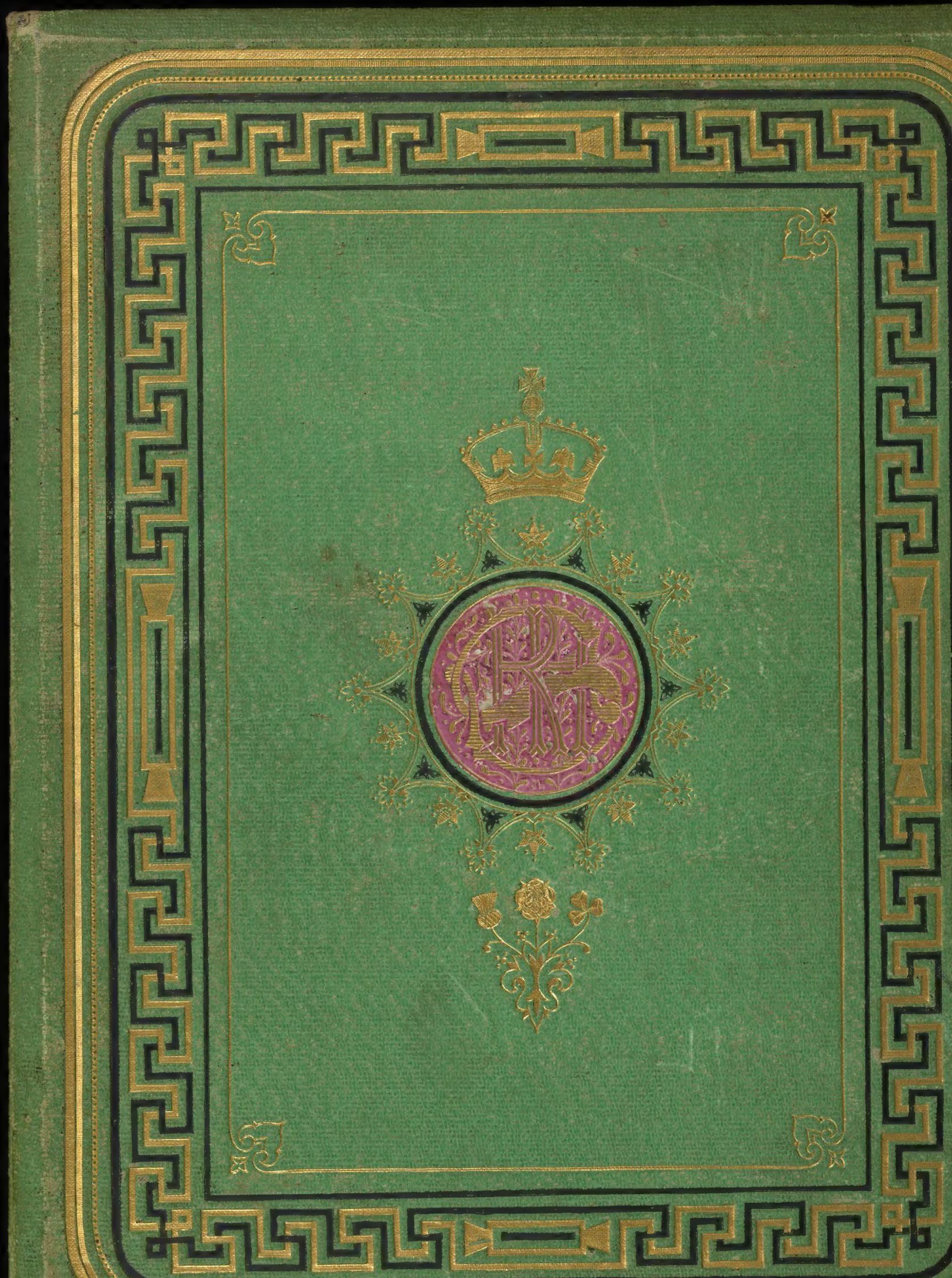

$\rightarrow$ 